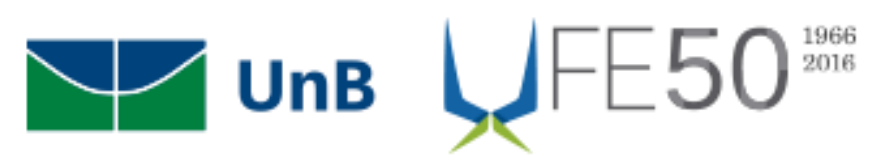

UNIVERSIDADE DE BRASÍLIA - UnB

FACULDADE DE EDUCAÇÃO - FE

PROGRAMA DE PÓS-GRADUAÇÃO EM EDUCAÇÃO

MODALIDADE PROFISSIONAL - PPGE/MP

GESTÃO DE POLÍTICAS E SISTEMAS EDUCACIONAIS

O PROGRAMA UNIVERSIDADE PARA TODOS - UMA ANÁLISE DA DEMOCRATIZAÇÃO DO ACESSO NUMA IES PRIVADA DO DISTRITO FEDERAL (2011 A 2015)

LUCIANA DA SILVA CASTRO

BRASÍLIA/DF

JUNHO DE 2016 


\section{O PROGRAMA UNIVERSIDADE PARA TODOS - UMA ANÁLISE DA DEMOCRATIZAÇÃO DO ACESSO NUMA IES PRIVADA DO DISTRITO FEDERAL (2011 A 2015)}

Dissertação apresentada ao Programa de PósGraduação em Educação - Modalidade Profissional da Universidade de Brasília, vinculada à Área de Concentração Políticas Públicas e Gestão da Educação, como requisito parcial para a obtenção do título de Mestre em Educação, sob a orientação do Professor Dr. José Vieira de Sousa.

BRASÍLIA/DF 


\title{
O PROGRAMA UNIVERSIDADE PARA TODOS - UMA ANÁLISE DA DEMOCRATIZAÇÃO DO ACESSO NUMA IES PRIVADA DO DISTRITO FEDERAL (2011 A 2015)
}

\begin{abstract}
Dissertação apresentada ao Programa de PósGraduação em Educação - Modalidade Profissional da Universidade de Brasília, vinculada à Área de Concentração Políticas Públicas e Gestão da Educação, como requisito parcial para a obtenção do título de Mestre em Educação, sob a orientação do Professor Dr. José Vieira de Sousa.
\end{abstract}

Brasília, 24 de junho de 2016.

\section{COMISSÃO EXAMINADORA}

Professor Dr. José Vieira de Sousa

(Orientador - Faculdade de Educação/Universidade de Brasília)

Professor Dr. Wellington Ferreira Jesus

(Examinador externo/Universidade Católica de Brasília)

Professora Dra. Adriana Almeida Sales de Melo

(Examinadora interna - Faculdade de Educação/Universidade de Brasília)

Professora Dra. Maria Abádia da Silva

(Membro suplente - Faculdade de Educação/Universidade de Brasília) 
Aos meus filhos Gabriel, Mariana e Ana

Luiza, por traduzirem a razão pela qual tento ser uma pessoa melhor, cotidianamente. 


\section{AGRADECIMENTOS}

São muitas as pessoas pelas quais devo agradecer. São agradecimentos de toda ordem e intensidade. Ao meu marido, agradeço por lidar com minha ausência em diversos momentos, ao longo desses dois anos e meio, administrando o dia a dia de três filhos, em fases tão diferentes. Ao Gabriel e à Mariana, devo agradecer a compreensão pelas vezes em que tiveram de abrir mão de minha companhia, a fim de que eu pudesse estudar, em pleno domingo de sol, por exemplo. Ainda sim, contei com a torcida de ambos, para que tudo desse certo no final. À Ana Luiza, caçulinha que veio no meio do percurso, agradeço por existir.

Agradeço ao meu orientador, Professor Doutor José Vieira de Sousa por sua postura, cuja seriedade acadêmica, contribuiu, sobremaneira, para meu amadurecimento intelectual. Como agradecimento de cunho pessoal, devo ressaltar sua compreensão, em reconhecer as dificuldades e alegrias advindas da presença de um bebê em casa. Essa sensibilidade fez toda a diferença para eu superar as adversidades e chegar até o fim. Obrigada professor!

Aos examinadores da banca, Professor Dr. Wellington Ferreira Jesus e Professora Dra. Adriana Almeida Sales de Melo agradeço por terem aceitado o convite para participar de minha defesa, com a certeza de que suas contribuições serão bastante profícuas e enriquecedoras.

Não posso deixar de agradecer aos bolsistas que reservaram um pouco de seu tempo para colaborar com minha pesquisa, assim como aos gestores que permitiram ser entrevistados. Sem a participação desses sujeitos, meu trabalho não teria sido realizado. Obrigada a todos!

Ao colega Elias, da Secretaria do Mestrado Profissional da FE/UnB por se preocupar com minha prorrogação de prazo, tomando todas as providências necessárias para que eu não tivesse problemas com minha defesa.

Com certeza, sem o sentimento de generosidade, não teria sido possível a conclusão deste trabalho. Desde a ajuda acadêmica à familiar, a contribuição de algumas pessoas foi fundamental na minha trajetória. Começando pela família, não posso deixar de citar minha mãe, minha sobrinha Kamilla, meu sobrinho Henrique, minha irmã Luciene e irmão Augusto Cesar e minha cunhada Gisele, que estiveram presentes, me apoiando desde sempre e, principalmente depois que minha pequena nasceu. Eles facilitaram minha rotina, de modo que eu conseguisse cumprir com algumas atividades do mestrado, nesse período. 
Meus colegas de turma, do Mestrado Profissional, também tiveram papel central no meu percurso. À Juliana devo agradecer sua ajuda decisiva para vencer as dificuldades que se impuseram na disciplina da Professora Girlene. Aos colegas Hilton, Ricardo, Desirée e Eduardo, agradeço por acreditarem ser eu uma pessoa com boas qualidades intelectuais, suas palavras foram sempre de incentivo e confiança. À Stéphanie e ao Renan, agradeço por compartilharem de seus trabalhos a fim de ajudar-me nas minhas fragilidades e dúvidas.

À Professora Girlene, meu agradecimento por colocar-se sempre à disposição, quando tive dúvidas em relação ao uso do Software Statistical Package for the Social Sciences - SPSS, para a análise do dados quantitativos da pesquisa. À Professora Abádia, agradeço pela amizade que se fez presente desde o início de nossa relação acadêmica, indo para além dos limites da universidade.

À minha amiga Maíra agradeço seu carinho, por afastar-se estrategicamente nos momentos em que precisei de tempo para dedicar-me à conclusão desta dissertação, não podendo dar atenção à nossa amizade.

Aos meus chefes do Ministério da Educação, Felipe Danziato e Emmanuel Macedo, meu muito obrigada! Vocês foram fundamentais nesta trajetória, por nunca terem criado obstáculos à minha participação nas atividades acadêmicas do curso. Esta liberdade foi essencial, devo isso a vocês!

Reservo, por fim, a última parte desses agradecimentos, para ressaltar a contribuição de três pessoas que só pode ser traduzida pelas palavras generosidade e doação. A primeira, minha cunhada-irmã Maria Germânia que se colocou sempre à disposição para ajudar, além de mostrar-se, a todo tempo, interessada por minhas conquistas. Sem sua ajuda, no âmbito familiar, com certeza tudo seria muito mais difícil, senão impossível.

À Rovênia e à Lukelly, meus agradecimentos especiais. Essas meninas foram determinantes para a finalização deste trabalho. Elas foram generosas, caridosas e amigas. Contribuíram com sua inteligência e desprendimento. Partilharam de seus trabalhos, de seus materiais e de suas ideias. Dividiram comigo seu tempo, ouvindo minhas angústias. Obrigada por tudo, vocês foram sensacionais.

Finalmente, agradeço ao MEC por oportunizar a chance de realizar esse Mestrado Profissional que tantas coisas me proporcionaram, acadêmica e pessoalmente. Foi, de fato, uma experiência enriquecedora. 
"Não há democracia efetiva sem um verdadeiro poder crítico".

(Pierre Bourdieu) 


\section{RESUMO}

Esta dissertação trata do Programa Universidade para Todos (PROUNI) sob a perspectiva da democratização do acesso em uma instituição de educação superior (IES) privada do Distrito Federal (DF). A pesquisa teve como objetivo geral analisar como o ProUni, vem contribuindo para a democratização do acesso à educação superior brasileira no período de 2011 a 2015. Este trabalho se configurou como um estudo de caso de caráter exploratório em que foram utilizados, como instrumentos de coleta de dados, questionários e entrevistas semiestruturadas. Para subsidiar a análise empírica, por sua vez, analisaram-se diversos documentos, como legislações e estudos educacionais, censos e pesquisas demográficas, relatórios institucionais, atas e diferentes dados estatísticos. Para completar o arcabouço analítico do fenômeno estudado, construiu-se um referencial teórico que possibilitou ampliar o cenário em que a política pesquisada está inserida. Mediante uma abordagem qualitativa com a utilização de dados quantitativos, se identificou o perfil dos beneficiários do programa, assim como a percepção de diferentes sujeitos acerca dessa política. Além dos bolsistas, outros sujeitos compuseram o escopo da pesquisa. Foram entrevistados três gestores do Ministério da Educação (MEC) ligados à educação superior, cinco da IES pesquisada e um representante da Associação Nacional de Mantenedoras de Ensino Superior (ABMES). Para a análise dos dados, optou-se por realizar uma triangulação das fontes, de maneira que fosse abordado o fenômeno de forma mais fidedigna possível. Além disso, lançou-se um olhar dialético sob o objeto proposto a fim de melhor analisá-lo, considerando, para tanto, as categorias metodológicas da totalidade, mediação e contradição. Além dessas, as categorias de conteúdo selecionadas a priori: democratização, expansão e equidade deram o norte à pesquisa, ajudando na compreensão do fenômeno à luz desses conceitos. Qualidade da educação básica e cotas emergiram da fala dos sujeitos e se consolidaram como categorias surgidas a posteriori. Foram explicitadas contradições relacionadas à relação público-privada; e realizadas mediações capazes de relacionar os sujeitos ao objeto à luz da historicidade que dá suporte à realidade dos fatos. Os resultados obtidos com a pesquisa confirmam a tese de que o ProUni está promovendo a democratização do acesso à educação superior na instituição privada investigada, considerando a compreensão das categorias sugeridas. No entanto, apontam para a necessidade de que ajustes devem ser realizados no atendimento à política pesquisada. Por tratar-se de um Mestrado Profissional, dentre os objetivos específicos tem-se a proposta de uma Nota Técnica a ser apresentada ao Ministério da Educação que, dentre algumas recomendações, destaca a necessidade de se criar ferramentas que garantam a permanência do bolsista no curso, até sua conclusão, ponto que se mostrou pacífico entre os sujeitos da pesquisa. Além disso, ressaltou-se a necessidade de se buscar incessantemente a qualidade das IES e dos cursos nelas oferecidos. Para este trabalho, a compreensão que se faz é de que não há democratização sem qualidade. A busca pela ampliação dos direitos é entendida como fundamental para a redução das assimetrias sociais, entre as quais, o déficit educacional. Portanto, tratar os desiguais, de maneira igualmente desigual, deve ser a lógica de uma política pública que se diz democratizante. Ademais, a constituição de ações afirmativas é necessária e as cotas, que concretizam essas ações, transformam-se em um meio de garantia de direitos historicamente relegados. O ProUni promove a democratização do acesso à educação (como ampliação de direito) quando evidencia os mais carentes e os negros, além de reservar vagas àqueles com deficiência.

Palavras-chave: Democratização do acesso. Educação superior privada no DF. ProUni. 
ABSTRACT
This dissertation is about a government program called Programa Universidade para Todos (PROUNI - Program University for All), from the perspective of the democratization of access to a private higher education institution (IES) in the Federal District (DF). The research aimed to analyze how ProUnihas contributed to the democratization of the access to Brazilian higher education during the 2011-2015 period. This research was constructed as an exploratorycase study where surveys and semi-structured interviews were used as data collection tools. In order to support this empirical analysis, several documents, such as legislation and educational studies, census and demographic research, institutional reports, minutes and different statistical data were analyzed. To complete the analytical framework of the studied phenomenon, a theoretical outline was developed to enable the expansion of the scenario in which the studied policy operates. Through a qualitative approachusing quantitative data, the profile of the beneficiaries was identified as well as the perception for the different subjects concerning this policy. Additionally to the scholarship holders, other subjects became part of the research scope. These other subjects include three delegates from the Ministry of Education (MEC) who relate to higher education matters, five representatives from the institution in research, and one representative from the Brazilian Association of Maintainers of Higher Education (ABMES). For the data analysis, it was decided to perform a triangulation of sources, so that the phenomenon was addressed in the most reliable way possible. Moreover, a dialectical view was cast under the proposed object in order to better analyze it, therefore, taking in consideration, the methodological categories of totality, mediation and contradiction. Besides these, the content categories selected a priori: democratization, expansion and equity directed the research, helping to understand the phenomenon based on these concepts. The quality of basic education and quotas emerged from the subject's interviews, therefore, these were consolidated as categories that emerged subsequently or a posteriori. The contradictions concerning to public-private relation were explained and mediations capable of relating the subjects to the object in the light of the historicity that supports the reality of the facts were performed. The results obtained from the research confirm the thesis that ProUni is promoting the democratization of the access to higher education in the private institution investigated, considering the comprehension of the suggested categories; however, these results point to the need to make adjustments in compliance with the researched policy. As this is a professional Master's work, one of its specific objectives is the proposal of a Technical Paper to be submitted to the Ministry of Education.Among some recommendations, the said document highlights the need to create tools that ensure the continuity of the scholarship beneficiary enrolled in the career, until completion; a point that showed common ground between the subjects. In addition, the need to constantly seek for the quality of higher education institutions and its courses was also emphasized. For this research, the understanding that is being accomplished is that there is no democratization without quality. The search for the expansion of rights is seen as crucial for the reduction of social disparities, including the educational deficit. Therefore, to treat the unequal equally unevenly must be the logic of a public policy that promotes democracy. Furthermore, the establishment of affirmative actions is needed, as well as quotas, which embody these actions, to turn into a means to ensure rights historically relegated. ProUni promotes the democratization of access to education (as the expansion of rights) when it highlights the most needed and the black population, as well as when it reserves opportunities for people with disabilities.

Keywords: Democratization of access. Private Higher Education in DF. ProUni. 


\section{LISTA DE ABREVIATURAS E SIGLAS}

AI

ABMES

$\mathrm{BM}$

CEBRASPE

CDES

Cefet

CEP

CEUB

CNE

Codeplan

Cofins

Colap

Conaes

Conap

DEED

DF

$\mathrm{EaD}$

$\mathrm{EF}$

EM

Enade

Enem

ES

ESCS

Eapes

FA - FBT

FARPLAC

$\mathrm{FCCH}$

FCHBSB
Ato Institucional

Associação Brasileira de Mantenedoras de Ensino Superior

Banco Mundial

Centro de Seleção e Promoção de Eventos da Universidade de Brasília

Conselho de Desenvolvimento Econômico e Social

Centro Federal de Educação Tecnológica

Comitê de Ética em Pesquisa

Centro de Ensino Unificado de Brasília

Conselho Nacional de Educação

Companhia de Planejamento do Distrito Federal

Contribuição Social para o Financiamento da Seguridade Social

Comissões Locais de Acompanhamento e Controle Social do Programa Universidade para Todos

Comissão Nacional de Avaliação da Educação Superior

Comissão Nacional de Acompanhamento e Controle Social do Programa Universidade para Todos

Diretoria de estatísticas educacional

Distrito Federal

Educação a distância

Ensino Fundamental

Ensino Médio

Exame Nacional de Desempenho dos Estudantes

Exame Nacional do Ensino Médio

Educação Superior

Escola Superior de Ciências da Saúde

Equipe de Assessoria ao Planejamento do Ensino Superior

Faculdade de Artes - Fundação Brasileira de Teatro (Faculdade Dulcina)

Faculdade de Reabilitação do Planalto Central

Faculdade Católica de Ciências Humanas

Faculdade de Ciências Humanas de Brasília 
FDBEF

Fepecs

FE-UnB

FHC

FICB

Fies

Foplac

Funai

FUB

Fundeb

Fundef

GDF

GI

GM1

GM

GT

IBGE

IDH

IES

Ifes

ICEX-AEUDF

IFET

ICS-AEUDF

Inep

IRBR

LDBEN

MB

MEC

ML

MP

MRE
Faculdade Dom Bosco de Educação Física

Fundação de Ensino e Pesquisa em Ciências da Saúde

Faculdade de Educação - Universidade de Brasília

Fernando Henrique Cardoso

Faculdades Integradas da Católica de Brasília

Fundo de Financiamento Estudantil

Faculdade de Odontologia do Planalto Central

Fundação Nacional do Índio

Fundação Universidade de Brasília

Fundo de Manutenção e Desenvolvimento da Educação Básica e de Valorização dos Profissionais de Educação

Fundo de Manutenção e Desenvolvimento do Ensino Fundamental e de Valorização do Magistério

Governo do Distrito Federal

Gestor Institucional

Gestor MEC1

Gabinete do Ministro

Grupo de Trabalho

Instituto Brasileiro de Geografia e Estatística

Índice de Desenvolvimento Humano

Instituição de Educação Superior

Instituição Federal de Educação Superior

Instituto de Ciências Exatas

Instituto Federal de Educação, Ciência e Tecnologia

Instituto de Ciências Sociais

Instituto Nacional de Estudos e Pesquisas Educacionais Anísio Teixeira

Instituto Rio Branco

Lei de Diretrizes e Bases da Educação Nacional

Matrícula Bruta

Ministério da Educação

Matrícula Líquida

Medida Provisória

Ministério das Relações Exteriores 
OCDE

OECD

OMC

PDE

PeNSE

PDAD

PIB

Pnad

PNE

Pnud

PPGE - MP

PPI

PR

Proer

ProUni

RA

Reuni

SCIA

SES-DF

$\mathrm{SESu}$

Sinaes

SisProuni

SM

SPSS

TCM

TIC

UAB

Ubec

UCB

UNE

ICSA
Organização para a Cooperação e Desenvolvimento Econômico

Organization for Economic Co-operation and Development

Organização Mundial do Comércio

Plano de Desenvolvimento da Educação

Pesquisa Nacional de Saúde do Escolar

Pesquisa Distrital por Amostra de Domicílios

Produto Interno Bruto

Pesquisa Nacional por Amostra de Domicílio

Plano Nacional de Educação

Programa das Nações Unidas para o Desenvolvimento

Programa de Pós-Graduação em Educação - Modalidade Profissional

Preto, Pardo ou Indígena

Presidência da República

Programa de Estímulo à Reestruturação e ao Fortalecimento do Sistema Financeiro Nacional

Programa Universidade para Todos

Região Administrativa

Programa de Apoio ao Plano de Reestruturação e Expansão das

Universidades Federais

Setor Complementar de Indústria e Abastecimento

Secretaria de Estado de Saúde do Distrito Federal

Secretaria de Educação Superior

Sistema Nacional de Avaliação da Educação Superior

Sistema do ProUni

Salário Mínimo

Statistical Package for the Social Sciences

Taxa de Crescimento Média Anual

Tecnologia de Informação e Comunicação

Universidade Aberta do Brasil

União Brasiliense de Educação e Cultura

Universidade Católica de Brasília

União Nacional dos Estudantes

Instituto de Ciências Sociais Aplicadas 
UniCeub

Unesco

UPIS

Usaid
Centro Universitário de Brasília

Organização das Nações Unidas para a Educação, a Ciência e a Cultura Faculdades Integradas da UPIS

United States Agency for International 


\section{LISTA DE GRÁFICOS}

Gráfico 1 - Percentual do PIB aplicado em educação em países ibero-americanos (Brasil, 2010)

Gráfico 2 - Evolução das matrículas em estabelecimentos públicos e privados no ensino 50 superior - (Brasil, 1933-1980)

Gráfico 3- Evolução bianual do número (bruto) de matrículas por categoria 76 administrativa - (Brasil, 1995-2003)

Gráfico 4 - Evolução do número de instituições de educação superior por categoria administrativa - (Brasil, 1995-2003)

Gráfico 5- Número de matrículas de graduação por modalidade de educação e 96 categoria administrativa - (Brasil, 2013)

Gráfico 6 - Bolsistas ProUni, por modalidade de educação- (Brasil, 2005 a 2014)

Gráfico 7 - Representação percentual da evolução de matrículas nas instituições de educação superior dos setores público e privado - (Brasil, 1995 a 2002 e 2002 a 2008)

Gráfico 8- Estudantes da rede pública e particular com distribuição percentual por quintos de renda per capita - Ensino Fundamental, Ensino Médio e Educação Superior (Brasil, 2013)

Gráfico 9 - Projeção da meta 12 do PNE 2014/2024 - Educação Superior

Gráfico 10 - Distribuição de pessoas com renda própria na casa do bolsista - 2016

Gráfico 11 - Distribuição quantitativa do nível de escolaridade do pai - 2016

Gráfico 12 - Distribuição percentual do nível de escolaridade da mãe - 2016 


\section{LISTA DE QUADROS}

Quadro 1- $\quad$ Legislações que tratam da relação entre ciência e setor produtivo entre 199486 e 2012 - Brasil

Quadro 2- $\quad$ Regiões Administrativas e data de criação - 2014 - Distrito Federal

Quadro 3- Categorias do método histórico dialético

Quadro 4- Modelo esquemático da técnica de triangulação na coleta de dados - 144 Triviños - 1987

Quadro 5- Curso do bolsista - 2016

Quadro 6- Ingresso de bolsistas pelo critério de políticas afirmativas - 2016

Quadro 7- Distribuição dos bolsistas segundo cor/raça -2016

Quadro 8- $\quad$ Sujeitos entrevistados - 2016

Quadro 9- Relação das respostas dos bolsistas, em ordem decrescente, segundo a variabilidade média - 2016

\section{LISTA DE TABELAS}

Tabela 1 - Estabelecimentos de ensino superior segundo dependência administrativa e natureza acadêmica - (1971-1980, Brasil)

Tabela 2 - Taxa de crescimento - matrícula bruta na educação superior por categoria administrativa - (1995 e 2002, Brasil)

Tabela 3 - Número e percentual de instituições por dependência administrativa-(1995 a 2003, Brasil)

Tabela 4 - Número de instituições, matrículas e vagas, segundo categoria administrativa (2011 e 2014, Brasil)

Tabela 5- Distribuição percentual da população brasileira e das matrículas na educação superior por cor ou raça - (2014, Brasil) 
Tabela 6 - $\quad$ Proporção da população por raça/cor -(2013, Distrito Federal )

Tabela 7 Número de concluintes, cursos e matrículas de graduação presencial e a 148 distância da IES pesquisada - 2011 a 2014

Tabela 8 - $\quad$ Distribuição dos bolsistas segundo valor de sua renda ${ }^{1}$ própria - 2016

Tabela 9 - $\quad$ Distribuição dos bolsistas segundo a renda familiar - 2016

Tabela 10 - Distribuição de ingressantes por processo seletivo - 2011 a 2015

Tabela 11 - Distribuição de bolsas por curso pesquisado - 2011 a 2015

158

Tabela 12 - Descrição estatística com cálculo da média e do desvio padrão - 2016 


\section{SUMÁRIO}

CONSIDERAÇÕES INICIAIS.

1 RELAÇÃO PÚBLICO-PRIVADO NA EDUCAÇÃO SUPERIOR BRASILEIRA: TENSÕES À VISTA.

1.1 A educação superior no Brasil e o desafio do acesso: dos primórdios à década de 1950.

1.2 Relação público-privado: da ditadura militar (1964 a 1985) ao primeiro mandato do governo Dilma Vana Rousseff (2011-2014)

1.3 A expansão da educação superior nos dois mandatos do governo de Fernando Henrique Cardoso (1995-1998 e 1999-2002).

1.4 Políticas de democratização do acesso à educação superior no governo de Luiz Inácio Lula da Silva (2003-2006 e 2007-2010)

1.5 Dilma Vana Rousseff (2011-2014) e as políticas de acesso e permanência na educação superior: velhos e novos desafios

2 PROGRAMA UNIVERSIDADE PARA TODOS: DEMOCRATIZAÇÃO DO ACESSO OU PRIVATIZAÇÃO DA OFERTA?

2.1 Democratização do acesso à educação superior: um fenômeno a ser entendido.

2.2 Programa Universidade para Todos: uma política que democratiza?..........

2.3 O ProUni e o Plano Nacional de Educação 2014/2024: acesso, permanência e qualidade como desafios para o próximo decênio.

2.4 A expansão da educação superior privada no Distrito Federal: um olhar a partir do governo Lula

3 O PROUNI E SEUS SUJEITOS: AVALIANDO EFEITOS E IMPACTOS.

3.1 Perspectivas de análise e interpretação dos dados...........................................

3.2 A instituição pesquisada no cenário da educação superior privada do Distrito Federal.

3.3 Caracterização dos sujeitos e dos cursos...............................................................

3.3.1 Perfil dos beneficiários no contexto dos cursos pesquisados. 
3.3.2 Gestores governamentais e dirigentes do setor privado.............................. 162

3.4 O olhar dos bolsistas sobre o ProUni: uma análise à luz dos beneficiados. $\mathbf{1 6 3}$

3.5 O que pensam os gestores? (MEC, IES e ABMES)................................. 168

3.5.1 A expansão da educação superior e o ProUni como condutor do processo de democratização do acesso, com equidade................................................... 168

3.5.2 ProUni e as cotas étnico-raciais: cadê a escola básica de qualidade?........... 177

3.6 Proposta de Nota Técnica à Secretaria de Educação Superior - Sesu e a possibilidade de incremento da Política.................................................................

CONSIDERAÇÕES FINAIS........................................................... 192

REFERÊNCIAS................................................................................... 204

APÊNDICES............................................................................................... 215 


\section{CONSIDERAÇÕES INICIAIS}

A presente pesquisa está inserida no Programa de Pós-Graduação em Educação Modalidade Profissional (PPGE-MP), da Faculdade de Educação da Universidade de Brasília (FE/UnB), na Área de Concentração Gestão de Políticas e Sistemas Educacionais (GPSE). O foco do trabalho é o Programa Universidade para Todos - ProUni, com ênfase na democratização do acesso à educação superior ${ }^{1}$; e tem-se como locus uma instituição privada do Distrito Federal (DF), com recorte em quatro cursos.

O Programa Universidade para Todos - ProUni que, em 2016 completou 12 anos de existência, foi instituído pela Medida Provisória (MP) n 213 de 10 de setembro de 2004 (BRASIL, 2004). Tal medida, além de dispor sobre a política, também regula a atuação das entidades beneficentes de assistência social na educação superior. A referida MP foi regulamentada pelo Decreto $\mathrm{n}^{\circ} 5.245$ de 15 de outubro de 2004 (BRASIL, 2004a) e convertida na Lei ${ }^{\circ}$ 11.096, em 13 de janeiro de 2005 (BRASIL, 2005).

Em que pese à relevância social do Programa, vale destacar que seus efeitos acadêmicos, socioeconômicos e, sobretudo, sua capacidade de democratizar ${ }^{2}$ o acesso à educação superior continuam sendo debatidos e questionados. Além disso, a relação públicoprivado, na qual se situam as ações dessa política, é outro ponto de tensionamento existente entre os sujeitos envolvidos com educação superior no país.

O ProUni já promoveu o acesso de milhares de estudantes à educação superior, via setor privado, desde sua criação. Entre 2005 e 2014, foram registrados 1.049 .645 bolsistas integrais e 447.580 parciais (MEC, 2015). Esse número não pode ser desprezado, considerando os entraves que o Brasil precisa enfrentar para reduzir os déficits educacionais que se impõem contra o acesso a esse nível de educação. Todavia, os questionamentos e polêmicas que envolvem esta política educacional também continuam a merecer o olhar

\footnotetext{
1 Antes da promulgação da Lei no 9.394/96 de 20 de dezembro de 1996 (BRASIL, 1996), que instituiu as diretrizes e bases da educação nacional (LDBEN), era comumente utilizada a expressão "ensino superior". No entanto, tal legislação a substituiu por 'educação superior'. Para Weber (2010), essa "redenominação" se deu para "enfatizar a dimensão necessariamente formadora e crítica que tal nível de formação comporta e de relacionar o domínio do conhecimento, sua crítica e seu uso social” (p. 1257). Esclarece-se, portanto, que, ao longo desta dissertação, toda vez que forem feitas referências ao período pós-promulgação da LDBEN, será utilizada a expressão "educação superior" para atendimento ao definido na norma.

2 Segundo o dicionário on-line de português, o verbo democratizar significa: tornar democrático. Tornar acessível a todas as classes; popularizar: democratizar o ensino. (DICIO, 2016). Para falar de democratização do acesso à educação superior a partir do ProUni, serão considerados as dimensões trazidas por Nogueira (2008) que aborda diferentes conceitos acerca do tema. Esse assunto será melhor analisado no capítulo 2.
} 
crítico dos pesquisadores, sendo este um dos pontos importantes que contribuíram para a opção de se pesquisar o referido Programa.

Nesta perspectiva, a compreensão do papel do setor privado para a educação superior do país exige certa digressão histórica, ainda que de maneira mais geral. Isto é necessário, sobretudo, para possibilitar uma adequada contextualização do objeto desta pesquisa, principalmente no que diz respeito ao início da atuação das instituições privadas e aos desafios presentes na questão do acesso aos cursos de graduação no Brasil. O elitismo, a relação público-privado relacionada à oferta de vagas, a diversificação institucional ${ }^{3}$ e a diversidade de cursos $^{4}$ são exemplos que caracterizam o debate em torno do tema.

A expansão da educação superior, por meio da ampliação de vagas, foi retomada ${ }^{5}$ a partir da década de 1990, mais precisamente, com o governo de Fernando Henrique Cardoso (FHC), em seus dois mandatos (1995-1998 e 1999-2002). No entanto, esse processo não garantiu o ingresso de estratos sociais até então excluídos. Esse fato, portanto, fez suscitar duas indagações de fundamental importância para a pesquisa desenvolvida e descrita nesta dissertação: (i) será que o aumento de vagas, pura e simplesmente, é suficiente para realizar a democratização do acesso, considerando dimensões como renda, raça e origem escolar? (ii) em que pese à ampliação do acesso, será que a qualidade dessa oferta foi uma preocupação presente nesse processo?

Sabe-se que para enfrentar a realidade acerca do déficit educacional de nível superior, alguns desafios foram se somando aos que já existiam, influenciando, sobremaneira, o processo de formulação das políticas públicas para o setor. O caráter elitista, assim como a relação público-privado da oferta desse nível de educação, são exemplos de temas que promovem discussões de cunho bastante ideológico (SOUSA, 2013). Todavia, ressalta o autor, questões desta natureza merecem ser mais bem examinadas, de forma que a complexidade da educação brasileira seja compreendida de maneira mais crítica e contextualizada.

\footnotetext{
${ }^{3}$ O Decreto $\mathrm{n}^{\circ}$ 2.306, de 19 de agosto de 1997 regulamentou para o Sistema Federal de Ensino artigos de diversas disposições legais, incluindo da LDBEN/96 e, em seu art. $8^{\circ}$, dispôs sobre as instituições de ensino superior, classificando-as em: universidades, centros universitários, faculdades integradas, faculdades e institutos superiores ou escolas superiores. Esse decreto regulamentou o art. 45 da Lei ${ }^{\circ}$ 9.394/96, cujo texto diz que "A educação superior será ministrada em instituições de ensino superior, públicas ou privadas, com variados graus de abrangência e especialização" (BRASIL, 1997).

${ }^{4}$ A diversidade de cursos está prevista no art. 44 da LDBEN/1996, inciso I, cuja redação foi alterada pela Lei ${ }^{\circ}$ 11.632, de 2007 (BRASIL, 2007a). No referido texto há a presença dos cursos sequenciais, além dos já existentes: graduação, pós-graduação e extensão.

${ }^{5}$ Outros momentos, referentes à expansão da educação superior no país foram abordados, ao longo do capítulo 1 , em diferentes períodos da história, sobretudo a partir da década de 1960. No entanto, foi dada ênfase aos governos FHC, Lula e Dilma.
} 
Não menos ideologizado, o debate envolvendo a questão da diversificação institucional e da diversidade de cursos também se impõe e é mais atual, pois trata de fenômenos que se consolidaram a partir da aprovação de normas legais como a Lei de Diretrizes e Bases da Educação Nacional (LDBEN) no 9.394, de 20 de dezembro de 1996 (BRASIL, 1996), e o Decreto $\mathrm{n}^{\text {o }}$ 2.306, de 19 de agosto de 1997 (BRASIL, 1997), que previam essas possibilidades. Nessa perspectiva, políticas focalizadas ${ }^{6}$ foram implementadas para enfrentarem os desafios do acesso à educação superior.

A respeito desta questão, pode-se dizer que a diversificação institucional promoveu um amplo crescimento de oferta de vagas pela iniciativa privada durante o governo de FHC, antes citado. Seguindo a mesma lógica, o governo de Luiz Inácio Lula da Silva (Lula), em seus dois mandatos (2003-2006 e 2007-2010) manteve também o protagonismo do setor privado, por meio do Programa Universidade para Todos - ProUni e do Fundo de Financiamento da Educação Superior - Fies ${ }^{7}$. No entanto, nesse último governo mencionado o setor público também contou com políticas de investimento voltadas às universidades federais, sendo a principal delas o Programa de Apoio a Planos de Reestruturação e Expansão das Universidades Federais - Reuni ${ }^{8}$.

A Presidente Dilma Vana Rousseff, em seu primeiro mandato de governo (20112014) manteve os programas educacionais implantados pelo seu antecessor, Luiz Inácio Lula

\footnotetext{
${ }^{6} \mathrm{O}$ conceito de política focalizada pode ser explicado de diferentes formas. Para tanto, é necessário considerar o peso ideológico que cada entendimento tem, sobre o tema. Kerstenetzky (2006) expõe três abordagens sobre esse modelo de política pública. Partindo dos conceitos universalização x focalização, a autora explica que o foco de um programa pode ter caráter residual, condicional ou de ação reparatória. Sobre o programa pesquisado nesta dissertação, entende-se que o conceito de ação reparatória é o que melhor o caracteriza. Os dois primeiros (residual e condicional) são mais voltados a uma lógica economicista, em que o mercado e a eficiência no uso dos recursos ditam as regras. Já em relação ao conceito de política focalizada, como uma ação reparatória, a autora explica que pressupõe "restituir a grupos sociais o acesso efetivo a direitos universais formalmente iguais - acesso que teria sido perdido como resultado de injustiças passadas [...] de desiguais oportunidades de realização de gerações passadas" (p. 570). Nesse sentido, entende-se que o ProUni e sua reserva de cotas objetivam ampliação de direitos, como prevê uma política de ação reparatória. Como exemplo de desigualdades que justificam a necessidade de implementação de tais políticas, Kerstenetzky (2006) ressalta a questão do acesso à educação no Brasil: "a universalização da educação pública no Brasil não elimina distâncias entre a realização de pobres e ricos, que sempre têm como alternativa o sistema privado. Parte do problema tem a ver com a desigualdade de renda pura e simples" (p. 570). Por isso, ela diz que em uma sociedade onde as desigualdades sociais são muito evidentes, a "focalização" faz-se necessária para que seja possível alcançar de forma razoável a universalização dos direitos, pautada por uma "[...] concepção republicana de direitos de cidadania [...], em que [...] A focalização seria um requisito da universalização de direitos efetivos, compatível com o princípio da retificação ou da reparação" (p. 571).

${ }^{7}$ Criado pela Lei $\mathrm{n}^{\mathrm{o}} 10.260$ de 12 de julho de 2001(BRASIL, 2001) o Fies é um programa de financiamento a estudantes de graduação, em instituições não gratuitas com avaliação positiva do Ministério da Educação. Em 14 de janeiro de 2010 o programa foi alterado pela Lei $n^{\circ} 12.202$ (BRASIL, 2010), promovendo a ampliação de seu alcance.

${ }^{8}$ Instituído em 2007 pelo Decreto no 6.096 de 24 de abril (BRASIL, 2007b), o Reuni objetivou ampliar o acesso e permanência na educação superior. Para tanto, às instituições que aderissem ao programa, se criaria condições para expansão física, acadêmica e pedagógica da rede federal de educação superior.
} 
da Silva. No entanto, ela avançou em relação à política de permanência do estudante na instituição de educação superior - IES, pública ou privada, ao criar programas de ajuda financeira, por meio da concessão de bolsa de estudo ${ }^{9}$. Além disso, em seu governo foi aprovada a Lei de $\mathrm{n}^{\mathrm{o}} 12.711$ de 29 de agosto de 2012 (BRASIL, 2012), conhecida como lei de cotas, que reserva vagas nas universidades e institutos federais a estudantes egressos da escola pública e à população formada por pretos, pardos e indígenas ${ }^{10}$. Essa lei, assim como a lei do ProUni, objetiva contribuir para o processo de democratização do acesso à educação superior, com equidade ${ }^{11}$.

Apesar das referidas políticas implementadas nos últimos anos, estudos revelam o quanto o país está aquém do razoável, no que diz respeito ao acesso à educação superior, tanto pela população jovem de 18 a 24 anos (taxa líquida), quanto por aqueles que estão fora dessa faixa etária considerada ideal para a formação universitária (taxa bruta) ${ }^{12}$ Quanto ao primeiro

9 O Programa Bolsa Permanência para alunos de universidades públicas foi criado pela Portaria $\mathrm{n}^{\mathbf{0}} 389$, de 09 de maio de 2013, do Ministério da Educação, com o objetivo de, entre outros: "viabilizar a permanência, no curso de graduação, de estudantes em situação de vulnerabilidade socioeconômica, em especial os indígenas e quilombolas;" além de "promover a democratização do acesso ao ensino superior, por meio da adoção de ações complementares de promoção do desempenho acadêmico" (BRASIL, 2013). Para o setor privado, foi criada a bolsa permanência, por meio da Portaria Normativa $\mathrm{n}^{\circ} 19$ de 14 de setembro de 2011, (BRASIL, 2011) do Ministério da Educação, que regulamentou o art. 11 da Lei $n^{\circ} 11.180$, de 23 de setembro de 2005 que "autoriza a concessão de bolsas de permanência a estudantes beneficiários do Programa Universidade para Todos [...]" (BRASIL, 2005), para custeio de suas despesas educacionais. Apenas alunos que usufruem de bolsa integral na instituição, têm direito a tal benefício.

10 Essas categorias raciais são definidas pelo Instituto Brasileiro de Geografia e Estatística - IBGE, responsável pelo Censo demográfico do país e por diversas outras pesquisas relacionadas às características populacionais do Brasil. Tal pesquisa começou a ser realizada em 1872 e a população (livre), dentre as opções sugeridas tinham as cores: branca, preta, parda e cabocla para se auto-definir. Em 1890 foi incluída a mestiça e retirada a cabocla. Sem essas duas, em 1940 foi incluída a amarela que teve o modelo alterado apenas em 1991 com a inclusão da indígena e em 2010 (último censo realizado); ao escolher a opção indígena, teria ainda que escolher sua etnia e língua falada. Segundo publicação do instituto a "percepção da necessidade de estudar, de forma abrangente e aprofundada, o significado, a construção e a utilização destas categorias conduziu ao planejamento de consultas com representantes dos movimentos negro e indígenas, pesquisadores [...] O objetivo era elaborar, conjuntamente, uma pesquisa que contribuísse para o entendimento dessas categorias raciais atendendo às demandas sociais". (IBGE, 2011, p. 14-15).

11 Apesar deste termo ser cunhado pelos organismos internacionais, não é este o foco adotado no presente trabalho. A respeito do termo equidade, Dias Sobrinho (2010) define de forma clara o que ele chama de "princípio da equidade". Para ele "princípio da equidade implica um imperativo ético de diminuição ao máximo possível das desigualdades sociais [...]. As políticas públicas de expansão e inclusão social constituem um passo importante na luta pela superação das desigualdades, porém, isoladamente, são ainda insuficientes para romper as hierarquizações e diferenciações de uma sociedade dividida entre excluídos e incluídos" (p. 1.238). Nessa mesma linha, Azevedo (2013) compreende que a equidade tem relação direta com justiça social. Ele diz que a "igualdade e equidade constituem valores essenciais para a construção de políticas públicas voltadas para a promoção da justiça social e da solidariedade [...]” (p. 131).

12 Ristoff (2013) e Sousa (2013) usam a expressão "taxa de escolarização" para fazer referência aos índices educacionais, por faixa etária, como é utilizado pelo Inep. Já Gomes e Moraes (2012) fazem uso dos termos matrícula bruta (MB) e matrícula líquida (ML) para fazer a mesma análise, conforme descrito nas pesquisas do Instituto Brasileiro de Geografia e Estatística - IBGE, que utiliza "taxa de frequência líquida e bruta". Além desses, o Inep (2014), descreveu os indicadores relacionados às taxas de escolaridade da educação superior, utilizando os conceitos da Pnad/IBGE, que são: i) Taxa Bruta de Escolarização na Educação 
grupo, o Brasil enfrenta grande déficit, situação que fica ainda mais evidente quando comparado aos países mais desenvolvidos, como Estados Unidos, Canadá, Coréia, Japão e grande parte da Europa, cujo percentual supera os 40\% (GOMES; MORAES, 2012; RISTOFF, 2014; SOUSA, 2013). De acordo com estudo realizado por Ristoff (2013a), em 2011, apenas 17,3\% da população com idade entre 17 e 24 anos frequentavam cursos em instituições de educação superior. Essa taxa indicou um cenário bem distante do que foi previsto no Plano Nacional de Educação (PNE) de 2001/2010 $0^{13}$, que estabelecia como meta, ao final do decênio de sua vigência, $30 \%$ desse grupo na graduação. Conforme destacou o autor, tal percentual seria ainda menor e mais preocupante caso não tivesse havido uma redução da população dessa faixa etária em relação a 2005. A diminuição significou quase dois milhões de jovens e, não fosse isso, o percentual da taxa de escolarização líquida de $17,3 \%$, à época, seria de $16 \%$.

No que tange ao acesso à educação superior por pessoas de qualquer faixa etária, denominada taxa de escolarização bruta, Ristoff (2013a) ressaltou que em 2011 o índice chegou a 30,5\%. É fato que devido à política de expansão das universidades públicas e das políticas de financiamento de vagas no setor privado, como é o caso do ProUni, o número de alunos, independentemente da idade, continuou crescendo. No entanto, pode-se afirmar que há um grande desafio pela frente, para que seja possível atender ao definido no novo Plano Nacional de Educação - PNE (2014-2024), aprovado pela Lei $n^{\circ} 13.005$ de 25 de junho de $2014^{14}$ (BRASIL, 2014). Em vigor até 2024, o referido Plano estabeleceu em sua meta $n^{\circ} 12$, a elevação da taxa bruta de matrícula para 50\%, até o fim do decênio, e da taxa líquida para $33 \%$, entre os jovens de 18 a 24 anos.

Superior - Percentual de pessoas que frequentam cursos de graduação na educação superior em relação à população de 18 a 24 anos; ii) Taxa Líquida de Escolarização na Educação Superior - Percentual de pessoas de 18 a 24 anos que frequentam cursos de graduação na educação superior em relação à população de 18 a 24 anos; iii) Taxa Líquida Ajustada de Escolarização da Educação Superior - Percentual de pessoas de 18 a 24 anos que frequentam cursos de graduação na educação superior ou já concluíram um curso de graduação em relação à população de 18 a 24 anos (p. 36). Neste trabalho não foi utilizada a "Taxa Líquida Ajustada", apenas as duas primeiras. Reitera-se, portanto, que "Taxa de Matrícula" e "Taxa de escolarização" são termos usados para fazer referência ao mesmo indicador, conforme utilizado pelos autores.

13 O Plano Nacional de 2001/2010 foi aprovado por meio da Lei $n^{\circ} 10.172$ de 9 de janeiro de 2001. Em seu texto há um diagnóstico da educação brasileira, em todos os níveis, definindo, na sequência, objetivos e metas a serem atingidos, ao final do decênio. Para a educação superior, o Plano estabeleceu, no item 4.3, que dispôs sobre a educação superior, "prover, até o final da década, a oferta de educação superior para, pelo menos, 30\% da faixa etária de 18 a 24 anos" (BRASIL, 2001).

14 Vale lembrar que a vigência do primeiro PNE acabou em 2010 e o outro deveria ter entrado em vigência logo depois, para que não se estabelecesse um vácuo entre um Plano e outro. No entanto, apesar de o Poder Executivo ter apresentado o Projeto de Lei $\mathrm{n}^{\circ} 8.035$ em 2010, o texto ficou sendo debatido, no âmbito do Poder Legislativo, durante quatro anos. Por isso, essa lacuna de tempo entre as leis. 
Ainda que existam diferenças metodológicas entre os institutos de pesquisa, em 2013, dados da $\operatorname{Pnad}^{15}$ (IBGE, 2015) indicavam uma taxa de frequência líquida, da população de 18 a 24 anos, de 16,4\% cursando a educação superior, muito longe da meta prevista pelo atual PNE. Apesar de pequenas variações, estes índices indicam os desafios que o país precisa superar para reduzir as desigualdades presentes na sociedade brasileira, as quais imprimem graves reflexos sobre o acesso à educação superior. Em regra, a formação educacional de um indivíduo tem relação direta com sua condição financeira e vice-versa. Por isso, fica evidente o quanto o Estado é responsável por criar políticas que contribuam para reduzir o abismo existente entre os ricos e os pobres; entre aqueles com formação acadêmica e profissional e os que, por falta de opção, não podem escolher profissão ou carreira. Ristoff (2013a) afirma que os problemas de evasão e repetência no ensino médio e o caráter elitista da educação brasileira dificultam a melhora no índice de escolarização dos jovens e o ingresso na educação superior.

Nessa linha, o então Ministro da Educação Fernando Haddad, (julho de 2005 a janeiro de 2012), ressaltou que as políticas educacionais devem fazer parte de um "todo sistêmico", superando a visão "fragmentada" na qual se pautou a educação no Brasil. Essa visão está explicitada, no documento publicado em sua gestão, denominado Plano de Desenvolvimento da Educação - $\operatorname{PDE}^{16}$ (MEC, 2007). Partindo da lógica de educação sistêmica, pode-se dizer que os números relacionados ao analfabetismo, à evasão, à repetência, assim como aos limites encontrados para o acesso à educação superior brasileira, compõem um todo desolador da história do Brasil, no que diz respeito aos desafios educacionais do país. Dentre esses desafios, destaca-se a taxa de analfabetismo de pessoas com 15 anos ou mais de idade, cujo percentual em 2014 foi de 8,3\%, chegando a 23,1\% entre aqueles com mais de 60 anos. Quando esses índices são vistos pela perspectiva regional, as

\footnotetext{
${ }^{15}$ A Pesquisa Nacional por Amostra de Domicílios - Pnad, realizada pelo Instituto Brasileiro de Geografia e Estatística - IBGE investiga anualmente as características gerais da população, além daquelas relacionadas à educação, ao trabalho, à renda, dentre outras. Tal levantamento contribui para a formulação de políticas direcionadas à melhoria das condições de vida da população brasileira. Além dos dados da Pnad - Síntese de Indicadores 2014 (IBGE, 2015), disponibilizada no site do IBGE, foram utilizadas, também, informações presentes em uma publicação do mesmo instituto denominada "Síntese de Indicadores Sociais - Uma Análise das Condições de Vida da População Brasileira", que abrange dados não só da Pnad 2013, como também do Censo Demográfico 2010, Projeção da População do Brasil por sexo e idade 2013, Sistema de Contas Nacionais, Pesquisa Nacional de Saúde do Escolar - PeNSE, Boletim Estatístico de Pessoal e Informações Organizacionais do Ministério do Planejamento, base de dados do INEP, dentre outros.

${ }^{16}$ O Plano de Desenvolvimento da Educação - PDE foi um documento lançado no governo Lula, pelo então Ministro da Educação Fernando Haddad, que descrevia as ações de sua gestão, frente ao Ministério. Segundo descrito no Plano, tal documento é "mais do que a tradução instrumental do Plano Nacional de Educação [é um] "conjunto de programas que visam dar consequência às metas quantitativas estabelecidas naquele diploma legal”. (MEC, 2007, p.7).
} 
diferenças ficam ainda mais evidentes e não menos preocupantes. As regiões Norte e Nordeste apresentaram, no mesmo ano e faixa etária, taxas de analfabetismo de 9\% e 16,6\%, respectivamente, muito acima dos índices da Sudeste $(4,6 \%)$, Sul $(4,4 \%)$ e Centro-Oeste $(6,5 \%)$, conforme a mesma fonte (IBGE, 2015).

Vale destacar, ainda, o quanto a origem racial descortina o fenômeno da desigualdade presente na sociedade, sobretudo em relação ao panorama da educação no país. Apesar do objeto desta pesquisa tratar da democratização do acesso à educação superior, citar os índices de analfabetismo entre pessoas de cores e raças diferentes pode ajudar a entender os desafios existentes em relação ao ingresso no nível educacional investigado, também para esses grupos. Os negros (somatório de pretos e pardos, conforme nomenclatura utilizada pelo IBGE) são fortemente atingidos pela desigualdade no acesso à educação, desde a base. Em 2013, 11,5\% dos negros com 15 anos ou mais de idade eram analfabetos. Entre os brancos, essa taxa caía para 5,2\%. Mesmo havendo uma redução considerável, comparada a 2004, a saber, negros $(16,3 \%)$ e brancos $(7,2 \%)$ (IBGE, 2014), é evidente a necessidade de incremento das políticas públicas que promovam a ampliação e democratização do acesso à educação em todos os níveis, abarcando os diversos grupos, não só raciais, mas também sociais.

Como exemplo de outros estratos que ficam à margem do acesso à educação, ressalta-se o relativo às pessoas de baixa renda e àquelas que moram no campo. $\mathrm{O}$ abismo educacional encontrado entre a parcela da população representada pelos $20 \%$ mais pobres $\left(1^{\circ}\right.$ quinto) em relação aos $20 \%$ mais ricos ( $5^{\circ}$ quinto) é revelador. A taxa de analfabetismo entre pessoas de 15 anos ou mais de idade, de moradores do campo, é de 20,8\%. Já entre os residentes urbanos, essa taxa fica em $6,4 \%$, o que corresponde a menos de um terço, comparada a dos camponeses. Nesta mesma faixa etária, entre a população mais pobre, destaca-se ainda o percentual de $13,9 \%$ de analfabetos, confrontando-se com a taxa seis vezes menor da parcela mais abastada, com um índice de 2,0\% (IBGE, 2014).

A reprodução desses índices assimétricos também foi evidenciada em estudo realizado por Ristoff (2014), sobre o perfil dos estudantes de graduação, a partir do questionário do Enade ${ }^{17}$. Portanto, na medida em que o Estado deixa de ser capaz de reduzir as assimetrias presentes na sociedade brasileira, no que diz respeito ao acesso à educação,

\footnotetext{
${ }^{17}$ Como um dos instrumentos que compõem o Sistema Nacional de Avaliação da Educação Superior - Sinaes instituído em 14 de abril de 2004, pela Lei no 10.861, o Enade "tem como objetivo aferir o desempenho dos estudantes em relação aos conteúdos programáticos previstos nas diretrizes curriculares do respectivo curso de graduação, e as habilidades e competências em sua formação" (INEP, 2016).
} 
mais distante fica o país de alcançar níveis similares aos de nações onde o incentivo educacional funciona como vetor para o desenvolvimento.

Para analisar o Programa Universidade para Todos - ProUni, fez-se necessário entender o contexto da educação superior no Brasil, principalmente, no que diz respeito à relação público-privado e seu significado em torno da oferta de cursos graduação. A relevância dessa compreensão se explica pelo fato de que a política em questão tem as instituições privadas como principais parceiras. Ressalta-se, ainda, que, historicamente no Brasil, o número de matrículas em instituições de nível superior se caracteriza pela predominância do setor privado, configurando-se como mais um motivo para se compreender a engrenagem que define os contornos dessa relação.

Portanto, a abordagem relacionada ao binômio público-privado que caracteriza o sistema de educação superior brasileiro precisou ser analisada à luz de algumas referências históricas, para se compreender o processo que definiu o protagonismo do setor privado na oferta desse nível educacional, no país. Foi, sobretudo, a partir da década de 1960, que as instituições privadas se consolidaram e ultrapassaram, em termos quantitativos, o número de vagas ofertado pelas IES públicas. Segundo Sampaio (2011) “Entre 1960 e 1980, o número de matrículas no ensino superior passou de 200 mil para 1,4 milhão, em um crescimento de quase 500\%; no setor privado, o crescimento foi de mais de $800 \%$ " (p. 29).

Também analisando este surto expansionista do setor privado, Sousa (2013) observou que as mudanças econômicas ocorridas ainda na década de 1950 contribuíram para o aumento da demanda por educação superior. Questões ligadas à "internacionalização da economia do país, por meio de medidas de aumento da instalação de grandes empresas nacionais" (p.21) favoreceram a mobilidade social de parte da população que viu a oportunidade de investir em negócios e empresas. Tal movimento contribuiu para que outra parcela da população enxergasse na formação educacional sua chance de também ascender social e economicamente. Por isso, a partir da década de 1960, a oferta deste nível de ensino diversificou-se com o fortalecimento do setor privado.

O modelo institucional em que os setores público e privado se dividem na oferta de educação superior no Brasil contribui para ampliar divergências e conflitos nas políticas de acesso e democratização. Na medida em que a arena de discussão e elaboração de uma política pública é composta por diferentes sujeitos, os interesses ficam mais evidentes. Considerando a complexidade da sociedade brasileira, marcada por uma forte desigualdade social, programas como o ProUni acirram as contradições presentes na relação públicoprivado e na própria sociedade. 
Desde sua criação, em 2004, o ProUni já concedeu mais de 1,4 milhão de bolsas (1.497.180) (MEC, 2015) a estudantes brasileiros de baixa renda. É exemplo de política focalizada, pois tem como objetivo atingir uma parcela da população que sem o Programa teria menos condições econômicas de acessar a educação superior. Apesar de seu grande alcance, a oferta dessas vagas pelo setor privado provoca discordâncias, sobretudo daqueles que defendem a prevalência do setor público na promoção da expansão e da democratização do acesso à educação superior no país. Nesse sentido, a análise dos diferentes discursos relacionados ao tema, foi fundamental para a compreensão do contexto político, institucional e social que envolve o Programa.

A motivação para trabalhar essa temática como objeto de pesquisa provém de três dimensões que se inter-relacionam: profissional, acadêmica e pessoal. Quanto à dimensão pessoal, o tema estudado fez-se instigante, por trazer como proposta a análise de uma política direcionada a grupos cuja condição socioeconômica é menos favorecida. Por ter feito parte, em grande medida, desse estrato social, poder avaliar, como pesquisadora, o alcance desse tipo de programa foi bastante motivador. $\mathrm{O}$ sonho de frequentar uma universidade pública sempre pareceu distante, pois a concorrência para o ingresso em uma Instituição Federal de Educação Superior - IFES era bastante acirrada. Na década de 1990, período em que houve a primeira tentativa de se ingressar na Universidade de Brasília $-\mathrm{UnB}^{18}$, as políticas de democratização do acesso à educação superior inexistiam. Ademais, as vagas das universidades públicas, em sua maioria, eram preenchidas por alunos egressos de escolas particulares.

O ingresso da autora desta dissertação no curso de História, do Centro Universitário de Brasília - UniCeub deu-se no ano de 1991. Vale destacar que o acesso à educação superior no Distrito Federal caracterizava-se, à época, pela alta concorrência das vagas ofertadas pelo segmento público que, até o ano de 2000, era representado apenas pela UnB. Quanto às

\footnotetext{
${ }^{18}$ A Universidade de Brasília foi criada em 1962, pela Lei no 3.998 de 15 de dezembro de 1961 que autorizou o Poder Executivo a instituir a Fundação Universidade de Brasília (FUB) com o objetivo de criar e manter a referida instituição (SOUSA, 2013, p. 99). Em 2001, foi criada a Escola Superior de Ciências da Saúde (ESCS) que, como o próprio nome revela, volta-se para a oferta apenas cursos desta área, especificamente, Medicina e Enfermagem. A ESCS vincula-se à Secretaria de Saúde do Distrito Federal (SES-DF) e é mantida pela Fundação de Ensino e Pesquisa em Ciências da Saúde (FEPECS), instituída pela Lei nº 2. 676, de 12 de janeiro do mesmo ano. Sousa (2013) esclarece que "ao instituir a FEPECS, o Governo do Distrito Federal acabou por assumir uma dupla responsabilidade; "dar suporte público para a regulamentação geral da mantida; e oferecer o aporte financeiro necessário para a criação e o desenvolvimento do curso de medicina proposto por essa IES" (p. 151).
} 
instituições privadas, até o ano de 1993 havia apenas treze ${ }^{19}$ desse segmento, portanto, a disputa acabava sendo acirrada também nelas, sobretudo nos cursos de alta demanda. Esse cenário reduzia muito as opções dos interessados em ingressar numa instituição de educação superior local. Dessa maneira, as vagas do setor privado, acabavam sendo ocupadas também por egressos de escolas particulares que apresentavam, em geral, melhor formação e condições de pagar as mensalidades.

Somado à dimensão pessoal, há de se destacar a relevância que esse tema ocupa no campo profissional e acadêmico da pesquisadora. Profissionalmente, ressalta-se a importância em aprimorar a capacidade de análise e avaliação de uma política pública educacional, considerando ser o Ministério da Educação o seu local de trabalho, desde 1994. Esse ponto consolida seu percurso e interesse no campo acadêmico, ao poder aliar o conhecimento teórico com a prática profissional, acompanhando as ações do governo, contextualizando-as histórica e politicamente. Nesse sentido, a pesquisa ora relatada considerou de grande importância problematizar o tema proposto a fim de se compreender o contexto nacional e regional do processo de expansão e democratização do acesso aos cursos de graduação.

O ProUni, como já destacado, surgiu num momento de forte demanda por educação superior e numa realidade em que essa oferta era, e continua sendo, predominantemente privada. Ratificada essa premissa, vale assinalar que essa análise leva em conta o modelo de Estado no qual as políticas públicas estão inseridas, pois sua ação subordina-se ao contexto político, econômico e social, do país.

Para abordar o caráter da expansão e da democratização da educação superior e seu impacto na sociedade, considerou-se a necessidade de dimensionar o quadro de escolaridade em que se encontrava a população. Para tanto, algumas características foram levantadas, considerando a intenção do governo em fazer do ProUni não só uma política de expansão, mas de democratização com equidade. Nesse sentido, percebeu-se a relevância de se destacar, dentre as características dos estudantes, não só a questão da renda, mas também de raça/etnia e condição física, além da origem escolar.

Desse modo, além da apresentação de alguns dados relativos ao tema, feita ao longo do trabalho, serão trabalhados conceitos para a compreensão do modelo de política educacional, de nível superior, do governo Lula, aqui entendidos como categorias de análise. Equidade como valor atribuído à justiça social, democratização, massificação e expansão foram as dimensões escolhidas, a priori, para explicar o ProUni, como política de

\footnotetext{
${ }^{19}$ Algumas instituições privadas ofertavam curso em uma área apenas, como a Faculdade Dom Bosco de Educação Física e a Faculdade de Artes Dulcina de Moraes (SOUSA, 2013).
} 
financiamento público, via setor privado, para a ampliação do espaço acadêmico a grupos economicamente desprovidos e socialmente discriminados.

Diante dessa constatação, a questão fundante da presente pesquisa é: em que medida o Programa Universidade para Todos, como política pública, promoveu a democratização do acesso à educação superior, em uma instituição privada do Distrito Federal nos anos de 2011 a 2015?

A partir dessa indagação, pode-se pressupor que o país não tem como prescindir do setor privado na oferta de educação superior, considerando a participação majoritária desse último no processo de ampliação do acesso aos cursos de graduação no país. Nesse sentido, levantam-se as seguintes questões de apoio àquela anteriormente apresentada:

a) Ao implementar programas como o ProUni o Estado está furtando-se à responsabilidade de formular políticas que garantam, respectivamente, o acesso a instituições de educação superior públicas e a permanência nelas?

b) Em que medida a definição e implementação da política do ProUni, pelo governo Luíz Inácio Lula da Silva, e sua continuidade no governo de Dilma Rousseff, seguiu a mesma lógica de estímulo ao setor privado praticada pelo governo Fernando Henrique Cardoso?

c) Como sustentar a tese de que a criação do ProUni contribuiu, ao mesmo tempo, para a democratização do acesso à educação superior, via setor privado, e para o aprofundamento da crise do setor público?

d) Em que proporção a continuidade do ProUni no governo Dilma Rousseff revela uma opção do Estado por manter esta política como protagonista na oferta desse nível educacional?

Como política de Estado ${ }^{20}$, o ProUni foi citado no Plano Nacional de Educação 2014/2024 como um dos programas que contribuirá para a ampliação e a democratização do acesso à formação superior no próximo decênio. Nesse sentido, é necessário que suas ações não repliquem as diferenças sociais e econômicas presentes na sociedade brasileira. Por entender que democratizar vai muito além de ampliar vagas, torna-se urgente garantir nas IES o ingresso de grupos historicamente marginalizados. Mais do que isso: é preciso garantir a qualidade dessa oferta.

O processo de democratização do acesso à educação superior deve estar imbuído, portanto, da preocupação em aumentar não só as vagas nas IES, mas ampliar também as possibilidades de um grupo cada vez maior e diversificado da sociedade. Além disso, esse

\footnotetext{
${ }^{20}$ Políticas de Estado e políticas de governo diferem-se, principalmente, pela forma como é elaborada. Oliveira (2011) observa que as "políticas de governo são aquelas que o Executivo decide num processo elementar de formulação e implementação de determinadas medidas e programas [...] já as de Estados são aquelas que envolvem mais de uma agência de Estado, passando em geral pelo parlamento [...]” (p. 329).
} 
movimento deve vir acompanhado de compromisso com a qualidade da oferta, pois caso isso não aconteça, o modelo excludente será replicado com a manutenção dos privilégios de uma minoria que sempre teve acesso às melhores condições educacionais. Dias Sobrinho (2013) considera que "uma educação de baixa qualidade também contribui com baixa qualidade para a construção da justiça social e para a diminuição dos desequilíbrios entre pobres e ricos, incluídos e excluídos” (p. 120).

Considerando o debate acerca da expansão e da democratização do acesso à educação superior e o ProUni, tem-se por objetivo geral deste trabalho: analisar como o Programa Universidade para Todos vem contribuindo para a democratização do acesso à educação superior brasileira no período de 2011 a 2015, em uma instituição privada de educação do Distrito Federal.

Articulados a esse objetivo mais amplo, seguem os objetivos específicos que pautaram este trabalho:

Analisar a capacidade do Programa em contribuir com a ampliação das taxas de escolaridade, promovendo a democratização do acesso ao nível superior, a partir do que foi definido pelo Plano Nacional de Educação (2014-2024);

Identificar o perfil dos bolsistas para verificar a capacidade do Programa em democratizar o acesso à educação superior, garantindo nos cursos de graduação o ingresso de grupos historicamente excluídos (pobres, negros, indígenas e pessoas com deficiência);

Analisar o olhar dos gestores públicos, no âmbito do Ministério de Educação (MEC), da instituição privada pesquisada e dos bolsistas em relação à capacidade do Programa de promover a democratização do acesso à educação superior, com equidade;

Apresentar Nota Técnica, com a síntese do que foi identificado pela pesquisa e as possibilidades de incremento da política.

A partir destes objetivos, optou-se por uma pesquisa definida como um estudo de caso, de caráter exploratório e com uma abordagem metodológica do tipo qualitativa, sem prescindir de dados quantitativos. Como o locus do trabalho é uma instituição privada do Distrito Federal, fez-se uma breve análise sobre o campo da educação superior local, abordando sua expansão nos últimos anos, sobretudo no âmbito do governo de Luiz Inácio Lula da Silva.

O Distrito Federal, assim como as demais Unidades Federativas do país, tem desafios para com a educação de sua população, em todos os níveis. É nesta perspectiva que esta pesquisa se propõe a identificar o quanto o ProUni contribuiu com o acesso à educação superior, a partir de uma IES privada da região. O DF tem apenas duas instituições de 
educação superior públicas federais (Universidade de Brasília - UnB e o Instituto Federal de Educação, Ciência e Tecnologia de Brasília - IFB), sendo a outra, considerada estadual (Escola Superior de Ciências da Saúde - ESCS), por ser vinculada ao governo do Distrito Federal e todas as outras privadas, totalizando 62 IES, segundo Censo da Educação Superior 2013 (INEP, 2015). Depreende-se, portanto, que políticas voltadas ao setor privado ocupem espaço importante na oferta de graduação local.

Diante disso, faz-se necessário entender como o Programa impactou na IES pesquisada, a partir dos cursos selecionados, conforme será detalhado no capítulo 3 , de forma a identificar o quanto o Programa promoveu, de fato, a democratização do acesso à educação superior, conforme prevê a lei que o instituiu.

Vários são os estudos e pesquisas que tratam da questão da democratização do acesso à educação superior, em geral, e do ProUni, em particular. Diferentes visões sobre o mesmo assunto são abordadas em teses, dissertações e artigos, sendo várias destas produções citadas, em certa medida, no decorrer deste trabalho.

Santana (2009) estudou o Programa enfocando o debate acerca da democratização do acesso à educação superior, sob a perspectiva dos alunos do curso de pedagogia de algumas instituições do Distrito Federal. A pesquisa revelou que tanto os estudantes bolsistas, como não bolsistas, consideram que o ProUni cumpre a função de democratizar o ingresso dos mesmos neste nível educacional. No entanto, uma parcela considerável dos educandos não beneficiários do Programa, devido à regra socioeconômica, não concorda que este objetivo seja atingido.

Almeida (2009) pesquisou de que forma estudantes de uma instituição privada do interior de São Paulo, percebem a política no que tange ao objetivo de promover a inclusão social sob a ótica política, econômica, pedagógica e social do Programa. A autora destacou que boa parte dos alunos acredita que o programa não democratiza, pois não universalizaria o direito à educação superior a todos que querem continuar os estudos.

Os trabalhos que abordam a visão dos estudantes sobre o tema convergem em alguns pontos. Para esse grupo, em geral, sem o ProUni, dificilmente, teriam condições de fazer um curso superior. Ademais, muitos acreditam que o diploma universitário promove a ascensão econômica por eles esperada, o que relaciona o Programa à mobilidade social. (ALMEIDA, 2009).

Ao estudar o ProUni por meio das variáveis trabalho, educação e juventude, Costa (2012) fez uma pesquisa sobre os egressos do Programa, enfocando, sobretudo, a inserção no mercado de trabalho e o impacto socioeconômico após a conclusão do curso. Além disso, ela 
fez um diagnóstico desses beneficiários, considerando a questão racial, familiar, profissional e econômica e traçou um panorama dos estudantes que ingressaram na educação superior pelo Programa Universidade para Todos. Enquanto isto, Sena (2011) escolheu um grupo de nove estudantes, de três instituições de educação superior de Minas Gerais, para realizar sua pesquisa. Em linhas gerais, seu trabalho concluiu que,

[...] apesar de viabilizar o acesso da população de baixa renda ao ensino superior [sic], o ProUni ainda é insuficiente, requer a adoção de ações oriundas de políticas públicas e das Instituições de Ensino Superior que, de fato, estimulem a permanência, a inserção e a conclusão do curso pelo bolsista. Apurou-se que, atualmente, a possibilidade de conclusão do curso tem se concentrado no esforço pessoal do aluno. (SENA, 2011, p. 7)

Assim como o trabalho de Costa (2012), o de Sena (2011) também identificou que o real interesse do beneficiário ao estudar era a possibilidade de ascender social e economicamente, além de acrescentar que, muitas vezes, o bolsista era o primeiro membro da família a ter acesso a um diploma de nível superior. Ao perceber-se, contudo, contemplado por um programa que promoveu um benefício ao qual ele dificilmente teria acesso, o bolsista torna-se acrítico da política, não identificando, às vezes, seus desvios e suas lacunas (SENA, 2011, p. 198).

Para falar sobre o ProUni, à luz da democratização do acesso à educação superior foco desta pesquisa - Arruda (2011) contribuiu, ao partir da análise de decisões governamentais que influenciam a formulação e implementação de políticas públicas. A autora considerou que a política pública representa, ideologicamente, o governo por meio do discurso, o qual serve como pano de fundo para justificar, no caso do ProUni, a democratização do acesso à educação superior. Para ela, "visões diferentes de Estado e política pública originam projetos diferenciados de intervenção” (p. 502)

Em artigos sobre o tema, Catani, Hey e Gilioli (2006), Arruda (2011), Saraiva e Nunes (2011) observaram que o Programa partiu da intenção do governo em alcançar a meta descrita no item 4.3 do Plano Nacional de Educação 2001-2010, que previa 30\% de estudantes, com idade entre 18 a 24 anos, cursando a educação superior até o fim do decênio.

Outros autores, como Carvalho (2006), Segenreich e Castanheira (2009) e Sousa (2010) consideraram que o Programa tinha como objetivo, salvar as IES, que contavam com grande número de vagas ociosas, decorrentes da expansão iniciada na década de 1960. Nessa linha, o primeiro ressaltou que 
[...] o Programa Universidade para Todos deve operar, à semelhança do PROER $^{21}$ para o sistema bancário, em benefício da recuperação financeira das instituições particulares endividadas e com alto grau de desistência e de inadimplência. (CARVALHO, 2006, p. 995)

Outra discussão presente na análise do Programa está relacionada à permanência do estudante. Para Carvalho (2006), apenas a universidade pública é capaz de oferecer certas condições que facilitam a vida do estudante, como "transporte, moradia estudantil, alimentação subsidiada, assistência médica disponível nos hospitais universitários e bolsas de trabalho e pesquisa" (p. 994).

Oliveira (2007), em sua tese de doutorado realizada na Universidade Federal de Pernambuco, ao analisar o ProUni sob a perspectiva da relação entre o público e o privado, fez uma ampla discussão, destacando as contradições e ambiguidades do tema. Em capítulo específico, o autor apontou algumas divergências em relação a trabalhos por ele abordados. Ao contrário de Carvalho (2006), por exemplo, quem comparou o ProUni ao Programa de Estímulo à Reestruturação do Sistema Financeiro Nacional - Proer, Oliveira (2007) observou que esse último tinha "outra lógica, outros objetivos e os custos incomparáveis com os do ProUni”. (p. 258). Carvalho (2006) também sugeriu que apenas as universidades públicas seriam capazes de oferecer condições para a permanência do aluno, até sua formação, enquanto Oliveira (2007) apresentou alguns dados que mostraram o reduzido alcance dos benefícios citados pela autora. Ele concluiu que a fragilidade em relação às políticas que contribuem para que o estudante carente permaneça na IES até a conclusão do curso atinge não somente o setor privado, mas também o público.

Por outro lado, mesmo com problemas de percurso, estudos como o de Amaral e Oliveira (2011), que problematiza o Programa a partir da visão dos beneficiários, concluem que, "como política de acesso ao Ensino Superior, $[\mathrm{sic}]$ o ProUni tem atingido seu públicoalvo: estudantes de baixa renda, com poucas chances de acesso ao Ensino Superior e que dificilmente seriam atendidos pelas IES públicas" (p. 886-887). Esse estudo inclusive confirmou a lógica, defendida pelo governo, de que o ProUni contribui para o acesso de estudantes na educação superior, sobretudo dos grupos historicamente alijados desse nível educacional. Além disso, os autores argumentaram que as vagas nas instituições privadas já

\footnotetext{
${ }^{21}$ Segundo Carvalho (2006) o "Programa de Estímulo à Reestruturação do Sistema Financeiro Nacional (PROER), instituído pela Medida Provisória $\mathrm{n}^{\circ} 1.179 / 95$, teve como objetivo prestar socorro financeiro aos bancos privados" (p. 998); e o ProUni teria a mesma função, só que no setor educacional, ou seja, salvar as instituições de educação superior que estariam enfrentando dificuldades financeiras, devido às vagas ociosas e à inadimplência.
} 
existiam, mas estavam ociosas e que o ProUni, sem grandes custos, aumentou o preenchimento dessas vagas, o que não seria possível caso o foco do Programa fosse o setor público.

Sendo assim, entre críticas e reconhecimentos de sua importância, o ProUni carrega diversos fatores que, inerentes a seu desenvolvimento, não podem ser desprezados na análise da política. Entre esses, cita-se: a ampliação e a democratização do acesso; a polêmica acerca da isenção fiscal; a problemática em torno da relação público-privado; a questão da permanência do aluno; bem como a possibilidade de ascensão socioeconômica. Para perpassar por esses e outros fatores inter-relacionados ao Programa, nada mais conveniente que levar em consideração a realidade prática em que essa política pública se viabiliza.

Desse modo, para analisar o ProUni foram utilizados diferentes instrumentos de coleta de dados, como entrevistas semiestruturadas, questionário, documentos, além do levantamento bibliográfico que constitui elemento intrínseco a toda pesquisa. Para Richardson (2014), a "abordagem qualitativa de um problema, além de ser uma opção do investigador, justifica-se, sobretudo, por ser uma forma adequada para entender a natureza de um fenômeno social" (p. 79). Sobre os questionários, ele explica que "cumprem pelo menos duas funções: descrever as características e medir determinadas variáveis de um grupo social” (p. 189).

Ao analisar as diversas maneiras de classificar as pesquisas, Gil (2002) destaca que a pesquisa exploratória "tem como objetivo proporcionar maior familiaridade com o problema com vistas a torná-lo mais explícito ou a construir hipóteses [e que] na maioria das vezes, assume a forma de pesquisa bibliográfica ou de estudo de caso" (p.41). No estudo ora apresentado, a pretensão foi abordar o fenômeno social, entendido como democratização do acesso à educação superior. Para tanto, o conhecimento do contexto e da história, tanto do objeto quanto dos sujeitos, foi fundamental para a percepção dos movimentos dialéticos, intrínsecos a qualquer política.

As entrevistas foram realizadas com gestores governamentais e da IES, coordenadores dos cursos pesquisados e um representante da associação do setor privado. Diante dos diferentes modelos de entrevistas que contribuem para o trabalho científico, optouse pela semiestruturada, com o intuito de evitar o engessamento da comunicação, caracterizada pela ausência de margem a um maior desenvolvimento do raciocínio do entrevistado, assim como acontece com as perguntas dos questionários.

Em relação às entrevistas semiestruturadas, Manzini (2003) destaca que "esse tipo de entrevista pode fazer emergir informações de forma mais livre e as respostas não estão condicionadas a uma padronização de alternativas". Ainda de acordo com o autor, "as 
perguntas poderiam ser designadas como explicativas ou causais. O objetivo desse tipo de pergunta seria determinar razões imediatas ou mediatas do fenômeno social” (p.3).

Diante da possibilidade fornecida pelas entrevistas, conforme chama atenção Manzini (2003), optou-se por permear o referencial teórico com alguns trechos das falas dos entrevistados $^{22}$. Essa opção deve-se ao objetivo de melhor ilustrar a relação existente entre a teoria e a realidade, construindo um diálogo esclarecedor a partir dessas dimensões. Nesse sentido, as respostas dos entrevistados não ficarão restritas ao capítulo relacionado à análise dos dados.

Por fim, por meio da análise documental, constituíram fonte de consulta: leis, decretos, resoluções, pesquisas e estudos institucionais que contribuíram, sobremaneira, para o entendimento do objeto de estudo desta pesquisa. Os documentos, segundo Ludke e André (1986) “constituem também uma fonte poderosa de onde podem ser retiradas evidências que fundamentem afirmações e declarações do pesquisador. Representam ainda uma fonte 'natural' de informação" (p. 39).

Para a interpretação dos dados das entrevistas foi utilizada a análise de conteúdo, considerando a abordagem dos temas e o sentido e significado das categorias selecionadas. Os questionários enviados via google forms aos ingressantes do ProUni foram analisados a partir da sistematização das informações realizada com suporte do software Statistical Package for the Social Sciences - SPSS, conforme será detalhado no capítulo 3.

Do ponto de vista estrutural, esta dissertação, encontra-se organizada em três capítulos, além das considerações iniciais e finais. No Capítulo 1 traz-se a abordagem do acesso à educação superior brasileira, com foco na tensão público-privada. Nessa parte foi feito um breve histórico do desafio de acesso a esse nível de formação, remontando ao período colonial, à década de 1950. Na sequência, a referida análise abrangeu o período militar, época em que se consolidou a oferta de educação superior privada no país. Abordouse também, as políticas de expansão e democratização do acesso à educação superior, nos governos de FHC, Lula e Dilma.

No Capítulo 2, a pesquisa aborda o Programa Universidade para Todos - ProUni e a democratização do acesso à educação superior, considerando as dimensões que envolvem o tema, como ampliação, permanência, equidade e qualidade. Discute, ainda, o papel do

\footnotetext{
${ }^{22}$ Apesar de algumas falas estarem presentes, ao longo da dissertação, o quadro com a descrição dos referidos sujeitos e os respectivos códigos de identificação encontra-se no capítulo 3, página 160. São exemplos: GI1 (Gestor Institucional 1); GM1 (Gestor MEC 1); RIP (Representante Instituições Privadas) . Em relação aos bolsistas, os códigos são B (bolsistas, 1,2,3...)
} 
Programa junto ao Plano Nacional de Educação - PNE 2014-2024 e, por fim, retrata a expansão da educação superior no Distrito Federal, no contexto do governo de Luiz Inácio Lula da Silva, considerando seus dois mandatos (2003-2006 e 2007-2010).

Por fim, no capítulo 3, apresenta-se a análise dos dados coletados, buscando imprimir, nessa análise, um olhar dialético, relacionando o objeto pesquisado às categorias metodológicas da contradição, mediação e totalidade, associando-as às de conteúdo. Formuladas a priori e a posterior, essas categorias foram definidas a partir das falas dos entrevistados, conforme destaca Franco (2008). Além disso, apresenta-se uma Nota Técnica a ser enviada à Secretaria de Educação Superior do Ministério da Educação, com sugestões formuladas a partir do resultado da pesquisa. 


\section{CAPÍtUlO 1 - RELAÇÃo PÚBLICO-PRIVADO NA EDUCAÇÃO SUPERIOR BRASILEIRA: TENSÕES À VISTA}

Este capítulo trata da questão do acesso à educação superior no Brasil e tem como foco a tensão entre o setor público e o setor privado. Para tanto, foi realizada uma breve digressão histórica, remontando os primórdios da educação brasileira, a partir da qual foram analisadas as tensões presente na relação público-privado e seu impacto na oferta de educação superior, com ênfase na Reforma Universitária de 1968 e seus desdobramentos, desde então. Assim, foi possível uma melhor compreensão do contexto que favoreceu a construção do modelo elitista vigente no país.

Pode-se dizer que a relação público-privado definida em meados dos anos 1960 foi retomada quando do governo de Fernando Henrique Cardoso, considerando seus dois mandatos, (1995-1998 e 1999-2002). Nesse período, o Plano Diretor da Reforma do Aparelho do Estado, apresentado em novembro de 1995, impôs um novo paradigma de gestão, pautado no gerencialismo, como meio de reduzir o papel social do Estado e de ampliar a ação do mercado em espaços anteriormente ocupados pelo setor público. A educação superior, que não ficou imune a essas mudanças, contou com novos arranjos. Ao longo do governo em questão, grande espaço foi concedido ao setor privado, por meio das novas instituições abertas, enquanto ao setor público não foi dado investimento.

As políticas de acesso à educação superior nos mandatos do governo de Luiz Inácio Lula da Silva (2003-2006 e 2011-2010) também contaram com a parceria do setor privado como estratégica para sua implementação. Os dados, como se verá no decorrer deste capítulo, não deixam dúvidas do protagonismo desse último setor, no entanto, no governo Lula, ao contrário do de seu antecessor, o setor público de educação superior foi mais assistido. Nesse período, duas políticas se destacaram: o Reuni e o ProUni - a primeira direcionada ao setor público, com propostas de investimento e ampliação das IFES; e a outra, objeto desta pesquisa, direcionada ao setor privado. O ProUni, considerada uma política proveniente de parceria público-privada, conta com grande apelo social por ter promovido o ingresso de milhares de estudantes em instituições de educação superior por meio de bolsas.

Finalmente, no primeiro mandato do governo de Dilma Vana Rousseff (2012-2014), destaca-se a continuidade do ProUni e, logo, o papel que o setor privado ocupou na oferta de educação superior também em seu governo. Não obstante, algumas ações foram inauguradas 
ou fortalecidas em sua gestão, como o Programa Ciência sem Fronteiras $\left(\mathrm{CsF}^{23}\right)$ e a política de bolsa permanência, respectivamente, sendo essa a que será abordada nesse capítulo.

Como será visto ao final do trabalho, e de forma preliminar nesta seção, um dos desafios que estão sendo postos, a partir das políticas de acesso aos cursos de graduação, é justamente a capacidade de manter o estudante, seja na IES pública ou na privada, até a conclusão de seu curso. Desse modo, conceitos como expansão, democratização e equidade foram levados em consideração para a análise da política educacional, objeto desta pesquisa. Ademais, também foram mediadas as contradições inerentes à política, com destaque para a dicotomia entre o setor público e privado e o papel que cada um tem na relação com a sociedade.

\subsection{A educação superior e o desafio do acesso: dos primórdios à década de 1950}

O primeiro modelo de organização educacional no Brasil foi implantado pelos jesuítas $^{24}$ no século XVI. Portugal não tinha interesse em desenvolver a educação no país, sobretudo em nível superior, pois temia que a sociedade escolarizada se insurgisse contra seu poder metropolitano. (SOUSA, 2013). Entre os séculos XVI e XVIII, os jesuítas foram os únicos responsáveis pela educação formal no país. A presença dessa ordem religiosa durou mais de duzentos anos (1549-1759) e resultou na gênese do ensino superior do país, ao ministrar cursos de filosofia e teologia. Parte da população, formada pela elite, que tinha acesso aos colégios jesuítas, buscava, posteriormente, as universidades europeias, para completar sua formação. A Universidade de Coimbra costumava ser o destino de uma parcela desses estudantes (FÁVERO, 2006).

No entanto, a partir do século XVIII, o rei de Portugal, não tendo mais interesse em dividir seu poder com a igreja e vendo-se ameaçado pelo crescente poder dos jesuítas,

\footnotetext{
${ }^{23}$ Ao pesquisar o programa, Borges (2015) explica que o CsF "foi idealizado pela Casa Civil da Presidência da República como parte das ações prioritárias para a retomada desenvolvimentista no Brasil”. (p. 25) A autora afirma ainda que o envio de estudantes e pesquisadores ao exterior e o aprimoramento de seus conhecimentos, além da atração de cientistas estrangeiros para atuar em projetos de pesquisa no país, compõem as frentes de mobilidade que direcionaram os recursos públicos do programa.

${ }^{24}$ Os padres conhecidos como jesuítas compunham a Ordem Religiosa chamada de Companhia de Jesus. Ela foi fundada em 1534 por Inácio de Loyola e surgiu como um movimento contra-reformista em reação à Reforma Protestante. Conforme Maciel e Neto (2006), a ordem jesuítica "tinha como objetivo sustar o grande avanço protestante da época e, para isso, utilizou-se de duas estratégias: a educação dos homens e dos indígenas; e a ação missionária, por meio das quais procuravam converter à fé católica os povos das regiões que estavam sendo colonizadas". (p. 467-468)
} 
nomeou o Marquês de Pombal $^{25}$ para, na condição de ministro, implementar uma reforma educacional em suas terras - entenda-se Portugal e colônias, sobretudo Brasil. Assim, na esteira do poder monárquico, o então ministro implantou uma reforma educacional com o claro objetivo de fortalecer o poder do soberano. A primeira medida foi expulsar esta Ordem Religiosa, cuja influência transcendia o caráter religioso de conversão dos colonos à fé católica. Como responsáveis pela formação educacional na colônia até o final do século XVIII, os jesuítas eram vistos como culpados por "todos os males da Educação na metrópole e na colônia, motivo pelo qual [...] foram responsabilizados pela decadência cultural e educacional imperante na sociedade portuguesa [...]" (MACIEL; NETO, 2006, p. 469).

A reforma pombalina, sob influência do movimento iluminista ${ }^{26}$, quis afastar a igreja do poder do Estado, separando as decisões políticas da influência religiosa, especialmente a da religião Católica. Essa decisão pautou-se mais em interesses políticos que na simpatia por crenças iluministas, entre as quais, a de que a emancipação intelectual servia de pilar para o movimento. O ideal de educação empreendida por Pombal, com a reforma do sistema, era usar a educação a "serviço dos interesses do Estado" (p. 471).

Talvez, por isso a universidade tenha demorado tanto para ser implantada, de fato, no Brasil, mesmo porque a discussão envolvendo o tema desinteressava ao governo. Os cursos criados no país após a chegada da família real ao Brasil, no início do século XIX, eram voltados ao atendimento das necessidades do Estado e de uma pequena parcela da sociedade colonial, mais abastada. Diferentemente disso, na Europa, a primeira universidade surgiu ainda na Idade Média, mais precisamente em Bolonha; e outras foram criadas, gradativamente, no continente. Na América Hispânica, as universidades surgiram com a colonização espanhola, no século XVI, sob a égide da Igreja Católica (DURHAM, 2003; ROSSATO, 2005).

A família real portuguesa chegou ao Brasil em 1808, fugindo das investidas napoleônicas em Portugal. Esse acontecimento contribuiu para reconfigurar a dinâmica

\footnotetext{
${ }^{25}$ Nomeado Ministro da Fazenda em 1750 por D. José I, o Senhor Sebastião José de Carvalho e Melo, o Marquês de Pombal, usufruiu de grande poder junto ao rei, o que o habilitou a implantar diversas reformas, não só educacionais, mas políticas, administrativas, econômicas e culturais. Maciel e Neto (2006) dizem que "essas reformas exigiam um forte controle estatal e eficiente funcionamento da máquina administrativa e foram empreendidas, principalmente, contra a nobreza e a Companhia de Jesus, que representavam uma ameaça ao poder absoluto do rei"' (p. 467).

${ }^{26}$ Os iluministas protagonizaram um movimento de contestação, à luz da racionalidade, baseada na ciência. Eles "compreendiam que a instrução conduziria não apenas a um acréscimo de conhecimento no sujeito, mas também a um aprimoramento do indivíduo que se instrui" (BOTO, 2010, p. 282). Ainda segundo a autora, "o iluminismo foi também um movimento de fé: fé na razão, no futuro, na flecha de um tempo, no comércio entre os homens e, finalmente, fé na educação" (p. 283). Resta saber que tipo adverso de iluminismo pautou-se a reforma pombalina que, no fundo, contrariava todos os preceitos iluministas originários.
} 
econômica, política e social da colônia. Cursos como medicina, engenharia, direito e de formação militar foram criados para a formação de profissionais que servissem às necessidades do "aparelho do estado e das elites locais” (DURHAM, 2003).

Vale ressaltar que ao governo metropolitano não interessava implantar o ensino superior na colônia. Aos que tinham condições financeiras, a Europa era o destino para obter o diploma de graduação. Aos demais habitantes, que formavam uma sociedade escravocrata, baseada no latifúndio e na agroexportação, restava esperar pela boa vontade do Estado em ampliar os direitos da população, implantando um sistema educacional que abarcasse todos os níveis de ensino.

Reflexo dessa historicidade, mais de quinhentos anos após a chegada dos portugueses ao Brasil, a população ainda carece de políticas educacionais que se assemelhem às de países que investem de maneira robusta neste setor. Apesar dos avanços que o país obteve nas últimas décadas, ainda há um grande déficit educacional que o Brasil precisa vencer. Para ilustrar, segue gráfico com o percentual do Produto Interno Bruto - PIB aplicado em educação em países ibero-americanos, no ano de 2010.

Gráfico 1: Percentual do PIB aplicado em educação em países ibero-americanos (Brasil, 2010)

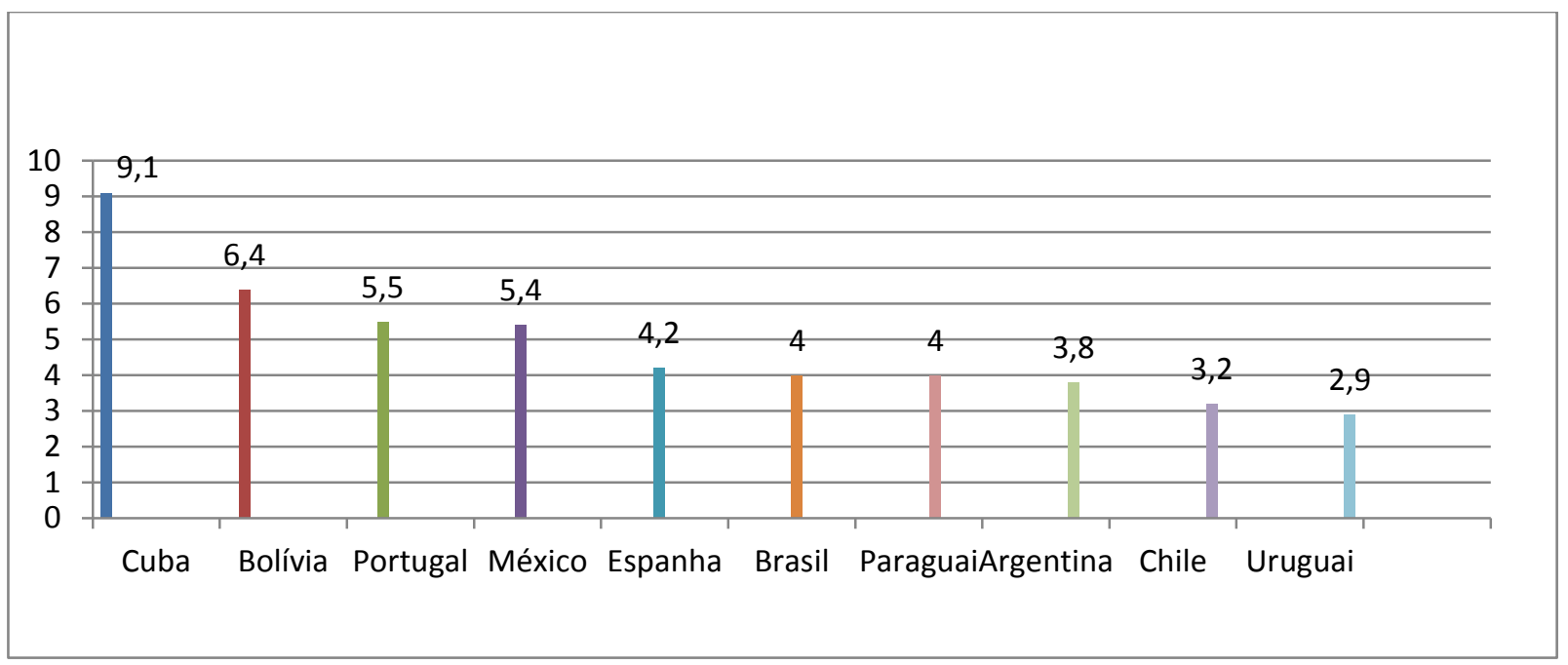

Fonte: Elaboração própria com base em Ristoff (2013, p. 526), dados de Unesco (2010) e de EUA: CIA (2010) e nos cálculos de Nelson Amaral (2013) e do próprio estudo.

De acordo com o gráfico 1, o Brasil aplica 4,0\% do Produto Interno Bruto (PIB) em educação, percentual menor que o de Cuba (9,1\%), Bolívia (6,4\%) e México (5,4\%). Ocupando apenas o $6^{\circ}$ lugar, o país também está atrás de Portugal $(5,5 \%)$ e Espanha (4,2\%). Ao analisar o valor bruto (em dólar) de investimento por pessoa em idade educacional nos 
mesmos países anteriormente citados, a situação brasileira fica ainda pior, caindo para $8^{\circ}$ lugar no ranking. Com o valor de U\$ 2.398, o Brasil está à frente apenas de Bolívia ${ }^{27}$ (U\$ 1.086) e Paraguai (U\$1.020). Segundo Ristoff (2013b),

[...] o Brasil tem quase a metade de sua população em idade escolar e, percentualmente, mais que o dobro de pessoas nesta faixa etária do que têm Portugal e Espanha. Se a comparação for ampliada para incluir outros países do mundo, observa-se que o Brasil tem hoje um dos maiores desafios educacionais do planeta. (p. 529)

É fato, portanto, que o Brasil, desde sua colonização até os dias de hoje, enfrenta grandes desafios em relação ao seu déficit educacional. Ao longo desses mais de 500 anos, o país teve alguns avanços e retrocessos, em grande medida pautados pelas posições ideológicas de seus governos. No caso da monarquia portuguesa, acreditava-se que a ignorância manteria a população distante dos movimentos iluministas que defendiam a liberdade e a independência. (MACIEL; NETO, 2006; SOUSA, 2013). Partindo desse raciocínio, pode-se afirmar que uma parcela da categoria dos políticos brasileiros, assim como de uma elite econômica, acredita que o conhecimento não é para todos. Essa separação de grupos contribui para a manutenção do status quo de uma minoria que acredita na perpetuação da ignorância (resultante da falta de educação formal) como meio de proteger seus interesses.

O indivíduo que não tem uma consciência crítica acerca de seus direitos contribui, na visão da autora desta pesquisa, para a perpetuação de sujeitos políticos preocupados apenas com seus interesses privados e que, muitas vezes, devem se submeter ao jugo de quem os explora, social e economicamente. O ProUni, de alguma forma, pode estar, juntamente com outras políticas, rompendo com essa lógica, ao promover a democratização do acesso à educação superior.

Em relação à formação nesse nível educacional, no período colonial, o Brasil seguiu a cartilha da metrópole, ao priorizar a formação de burocratas para a administração estatal e de profissionais liberais, interessados em desenvolver seus próprios negócios, além de atender à elite local, com a formação de médicos, engenheiros e advogados. De caráter pragmático, segundo o modelo napoleônico de universidade, as escolas autônomas de ensino superior que

\footnotetext{
${ }^{27}$ Apesar de a Bolívia estar à frente do Brasil e de vários outros países, em relação à distribuição percentual do PIB (segundo esse estudo) para a educação, quando o valor absoluto per capita da população em idade escolar, é considerado, o país cai da $2^{\mathrm{a}}$ para a $9^{\mathrm{a}}$ posição no ranking composto pelos países da Ibero-América. Isso se dá devido ao baixo valor do seu Produto Interno Bruto e sua relação com a quantidade de pessoas em idade educacional (AMARAL, 2013; RISTOFF, 2013b).
} 
funcionavam no Brasil, pautavam-se no utilitarismo, com seus cursos voltados a interesses momentâneos. (CUNHA, 1986; DURHAM, 2003; SOUSA, 2013).

Fazendo uma rápida analogia com o modelo do sistema federal de educação superior atual, pode-se dizer que a diversificação institucional e a diversidade de cursos nele prevista, atende a um caráter pragmático, na medida em que a formação volta-se aos interesses econômicos e desconsidera o papel emancipador (no sentido filosófico) de que toda formação acadêmica deveria estar imbuída. Os cursos aligeirados (curta duração) e as instituições que prescindem da pesquisa, como um dos pilares que constituem o tripé ensino, pesquisa e extensão, presentes na universidade atendem a esse tipo de formação. Diante desse contexto, o ProUni sofre críticas, pois os defensores da universidade pública o veem como um meio de fortalecer o setor privado sem garantir o compromisso com a formação do indivíduo, a qual deveria estar pautada na qualidade em todas as suas dimensões: individual, econômica e social. Para explicar a origem desse modelo de educação utilitarista no Brasil, Cunha ressaltou que 0

[...] novo ensino superior nasceu sob o signo do Estado nacional, dentro ainda dos marcos da dependência cultural aos quais Portugal estava preso. A partir de 1808, foram criados cursos e academias destinados a formar burocratas para o Estado e especialistas na produção de bens simbólicos; como subproduto, formar profissionais liberais. (1986, p.62).

Na esteira desse modelo, a República, proclamada em 1889 sob forte influência positivista, concentrou-se na formação de quadros para o Estado burocrático e militar. Portanto, a maior parte da sociedade brasileira continuou alijada do acesso à educação. $\mathrm{O}$ ensino superior manteve-se elitista, voltado, por conseguinte, ao atendimento dos interesses de uma minoria.

Em uma primeira aproximação de análise, percebe-se que o ProUni, apesar das críticas e em que pese seu modelo de formação, ampliou o acesso à educação superior a partir da previsão, em lei, de ação afirmativa que alcance grupos historicamente excluídos. Pode-se afirmar que, como resultado de uma colonização baseada na exploração econômica e na submissão político-social do povo, a exclusão perdurou ao longo da história do Brasil, de maneira que chegou ao século XXI com profundos abismos a serem superados. Sobre aquele momento histórico e sua formação educacional elitista, Cunha (1986) destacou que

[...] todo esse processo de ampliação e constituição da burocracia pública e privada determinou o aumento da procura de educação escolar pela qual se processava a formação profissional necessária ao desempenho das tarefas 
que lhe eram próprias. Os latifundiários queriam filhos doutores, não como meio de lhes dar a formação desejada para o bom desempenho das atividades políticas e o aumento do prestígio militar, como, também, expediente para atenuar possíveis situações de destituição. Os trabalhadores urbanos e os colonos, por sua vez, viam na escolarização dos filhos um meio de aumentar as chances desses ingressarem numa ocupação burocrática (p. 162)

Essa preocupação em formar doutores e burocratas demonstra bem o caráter elitista da sociedade brasileira no que diz respeito à origem e ao desenvolvimento da história do ensino superior no país. Tal característica esteve presente tanto nas instituições privadas quanto nas públicas, isso porque essas últimas, apesar de gratuitas, sempre foram elitistas, em parte pela dificuldade de ingresso e pelo reduzido número de vagas. Quanto às privadas, seu custo mantinha quem não podia pagar, distante do sonho de fazer uma graduação.

Pode-se dizer que apenas no final do século XX e início do XXI, com a ampliação da oferta em instituições privadas, aumento das vagas públicas e, na sequência, com políticas afirmativas para a inserção de grupos historicamente impedidos de ter acesso aos cursos de graduação, os governos começaram a pensar em políticas de expansão e democratização desse nível de educação. Todo esse movimento não deixou de ser acompanhado por intensos debates, sobretudo em relação ao papel da educação para a formação do indivíduo, mas também, sobre o modelo de sistema educacional que o país assumiu, desde os primórdios.

Importante destacar que as políticas públicas ${ }^{28}$ educacionais assumem diferentes contornos quando analisadas à luz dos governos que as propõem. Considerando que a desigualdade social está presente e arraigada na sociedade brasileira, desde o período colonial, pode-se dizer que a dinâmica do modo de produção capitalista não só contribuiu com o abismo existente entre as classes sociais, como também o aprofundou. Um país onde a escravidão durou mais de três séculos (XVI-XIX) fica difícil imaginar que a herança deixada por tanto tempo de exploração seja superada após a assinatura de uma lei, como a que libertou os escravos do jugo de seus algozes. A injusta formação da sociedade brasileira reflete nos níveis educacionais.

À luz da lógica do capitalismo e de suas consequências para o fortalecimento das desigualdade; e tendo como base a teoria marxiana, Boneti (2006) explica que

\footnotetext{
${ }^{28} \mathrm{O}$ conceito de políticas públicas é bastante amplo. Diferentes teóricos, sobretudo da Ciência Política, abordam o tema. Souza (2006) fez uma análise desses conceitos e definiu a política pública, como "campo do conhecimento que busca, ao mesmo tempo, 'colocar o governo em ação' e/ou analisar essa ação [...] e, quando necessário, propor mudanças no rumo ou curso dessas ações”. Sobre a etapa referente à formulação de políticas públicas, a autora diz que "constitui-se no estágio em que os governos democráticos traduzem seus propósitos e plataformas eleitorais em programas e ações que produzirão resultados ou mudanças no mundo real”. (p. 26)
} 
[...] a teorização do modo de produção capitalista e, porque não dizer, da própria modernidade, feita por Marx, tem como base justamente o papel dialético da desigualdade. Esta representa, no modo de produção capitalista, a integração e a desintegração, o fundamento da alienação do trabalhador e, consequentemente, a ideia da perpetuação da relação desigual, a base fundamental da luta de classes e o motor do conflito que propicia mudança. A desigualdade entre as pessoas proprietárias dos meios de produção e as da força de trabalho tem como sustentáculo a exploração de classe (p.32).

Devido à ausência de políticas educacionais capazes de inserir no contexto da educação superior parcela da população que não podia, no século XIX, completar seus estudos nas universidades europeias - como faziam os filhos da elite latifundiária e de comerciantes -, explica, de certa forma, o modelo elitista e excludente de sociedade brasileira. Confirmando essa tendência que marcou a evolução do ensino superior no Brasil, Sampaio (2000) diz que desde

[...] 1808, quando foram criadas as primeiras escolas de ensino superior, até a proclamação da República, em 1889, o ensino superior, se desenvolvera muito lentamente. $\mathrm{O}$ ensino seguia o modelo de formação para profissionais liberais em faculdades isoladas e visava a assegurar um diploma profissional, que dava direito a ocupar posições privilegiadas no restrito mercado de trabalho e a garantir prestígio social (p. 37 e 38 ).

Outro aspecto sui generis da história da educação superior brasileira, em relação a países da Europa e da América diz respeito ao papel da igreja. Essa instituição, tão presente na formação educacional de outros países, não conseguiu atuar com a mesma intensidade em Portugal, nem em suas colônias. Para Durham (2003), durante o século XIX, "a Coroa manteve a tradição do monopólio do ensino superior, resistindo à pressão da Igreja para a criação de estabelecimentos católicos” (p. 195). Pode-se afirmar que, no Brasil, a oferta de ensino superior, de caráter confessional, ficou restrita ao setor privado. O Estado conseguiu impor sua prevalência pela oferta pública e laica. Para confirmar essa tendência, cita-se o $\S 6^{\circ}$, do artigo 72, da Constituição Federal de 1891: “Será leigo o ensino ministrado nos estabelecimentos públicos" (BRASIL, 1891).

Esse mesmo texto constitucional previu a descentralização da oferta do ensino superior, permitindo a criação de instituições públicas estaduais ou municipais, assim como o surgimento de escolas privadas. Essas pertenciam, em sua maioria, à Igreja Católica e a grupos da elite local. Registra-se que, de 1889 a 1918, testemunhou-se a criação de 56 escolas superiores, direcionadas a cursos de diferentes áreas, como medicina, odontologia, direito e engenharia. Tal expansão foi facilitada pelas reformas educacionais de Benjamin Constant e 
esse período marcou, portanto, o caráter diversificado do sistema de ensino superior brasileiro. (DURHAM, 2003; SOUSA, 2013).

Acerca do surgimento do setor privado, como ator na oferta de ensino no país, Cury (2009) chamou o referido processo de "desoficialização" do ensino no Brasil e considerou a Reforma Rivadávia Corrêa, realizada entre 1911 e 1915, determinante para esse movimento. Segundo o autor, a interpretação enviesada de alguns artigos da Constituição Federal de 1891 possibilitou ao governo ratificar sua tendência em abrir espaços, a outros setores da sociedade, para a oferta de ensino. Nesse sentido, o autor citou o artigo 72 e seus respectivos $\S 8^{\circ}, \S 12^{\circ}$ e o $\$ 24^{\circ}$ como justificativa do governo para a implementação das medidas. Os referidos artigos destacam, sobretudo, a questão da liberdade de pensamento, de associação, de reunião e de livre exercício da profissão. Ainda segundo o autor, o Decreto $\mathrm{n}^{\circ} 8.659$, de 05 de abril de 1911, que instituiu a Lei Orgânica do Ensino Superior e do Fundamental da República, foi o primeiro documento que assumiu, claramente, "a desoficialização" do ensino público.

Percebe-se, a partir dessas normas, que o ensino privado remonta ao século XIX, com a previsão no texto constitucional de 1891 e nas leis infraconstitucionais do início do século XX. Esse cenário leva à constatação de que o modelo híbrido de oferta de educação superior brasileira, que prevê a participação dos setores público e privado, confunde-se com a própria história desse nível educacional no país. Portanto, quando se critica o governo por esse criar políticas educacionais envolvendo o setor privado, como o ProUni, deve-se refletir sobre a possibilidade de, certos grupos, prescindirem desse tipo de política. Diante do contexto aqui explanado, vê-se que é preciso considerar o tamanho do desafio vis-à-vis as profundas dívidas sociais que o Brasil tem com a população, em geral, e, em particular, com a pobre e negra.

Ao fazer um panorama da oferta de ensino superior no país, destacando suas características, Cunha (1997) enumerou "três vetores" da expansão para explicar esse desenho. São eles:

- $\quad$ a presença do governo federal nos estados (em geral nas capitais) pela criação e manutenção de faculdades;

- a projeção das elites locais e regionais no ensino superior na reprodução de quadros intelectuais, pela criação e manutenção de faculdades estaduais na capitais e nas cidades politicamente mais importantes do interior;

- a criação de faculdades por agentes privados, confessionais e/ou empresariais, conforme a demanda não atendida pelo setor público e de acordo com projetos hegemônicos. (p. 14). 
Os primeiros anos do século XX foram férteis para a história do ensino superior no Brasil. O surgimento das primeiras universidades, devidamente institucionalizadas, deu-se como produto de debates que vinham se encorpando em setores da sociedade, pautados em “discussões e necessidades da época de sua criação, em termos, sobretudo, do que era entendido como processo de modernização para o país e de sua contribuição para tal processo" (SOUSA, 2013, p. 19).

Em 1920 foi criada a Universidade do Rio de Janeiro, atualmente denominada Universidade Federal do Rio de Janeiro (UFRJ). Outra importante instituição de educação superior surgiu na década seguinte, chamada Universidade de São Paulo (USP). Fundada em 1934, essa última ocupa lugar de destaque no cenário educacional brasileiro e mundial, muito devido ao fato de ser a maior universidade pública do país e uma das maiores da América Latina. Segundo Sousa (2013), essa IES foi "considerada, de fato, a primeira universidade constituída no país, na medida em que trazia em seu projeto de fundação uma concepção universitária" (p. 19). O autor destacou, contudo, que seu surgimento foi marcado por “expressivos conflitos ideológicos e servido, em suas primeiras décadas de existência, à formação das elites [...] dotada de altos conhecimentos culturais, científicos, literários e artísticos" (p. 19 - 20). Assim, pode-se dizer que mesmo universidades públicas, como a USP, surgiram com um perfil elitista. Embora haja essa característica, a referida universidade opôsse ao modelo totalitário que Vargas infligiu, tanto ao Estado quanto à educação, naquele período.

A descentralização promovida nos anos iniciais da primeira república foi revertida pela administração de Getúlio Vargas, já indicando o viés autoritário desse. Vargas optou pela centralização política, que refletiu na oferta de educação no país. Com a criação do Ministério da Educação e Saúde Pública em 14 de novembro de 1930, o titular da pasta, Francisco Campos, empreendeu uma reforma, que levou seu nome, caracterizando-se por uma grande quantidade de legislações. Abarcando os níveis secundário, superior e comercial, as propostas reformistas intencionaram, segundo Fávero (2006),

[...] adaptar a educação escolar a diretrizes que vão assumir formas bem definidas, tanto no campo político quanto no educacional, tendo como preocupação desenvolver um ensino mais adequado à modernização do país, com ênfase na formação de elite e na capacitação para o trabalho (p. 23).

Por meio dessas regulamentações, o governo de Vargas impôs seu modelo de educação superior com ênfase na formação da elite e qualificação para o trabalho. 
Contrastando com o perfil autoritário de seu governo, a referida Universidade de São Paulo representou um antagonismo já no que tange às suas finalidades, como "a) promover, pela pesquisa, o progresso da ciência; b) transmitir, pelo ensino, conhecimentos que enriqueçam ou desenvolvam o espírito, ou seja, úteis à vida; c) formar especialistas em todos os ramos da cultura" (FÁVERO, 2006, p. 25).

Idealizada por Anísio Teixeira, em 1935 foi criada a Universidade do Distrito Federal (UDF), com a proposta de ser uma instituição preocupada em "difundir conhecimentos e preparar profissionais de artes e ofícios, mas também empenhar-se em manter a atmosfera de saber pelo saber, demonstrando inquietações com a formação intelectual do ser humano" (SOUSA, 2013, p. 20). Fica claro, portanto, o motivo pelo qual essa universidade não perdurou, pois abrigada por um governo autoritário e centralizador, manter-se fiel aos seus propósitos seria praticamente impossível. Liberdade de expressão e investimento intelectual são valores que não se coadunam com autoritarismo e repressão. Nesse sentido, menos de quatro anos foram suficientes para a proposta de Anísio sucumbir e a universidade ter suas portas fechadas. Para Fávero (2006), "essa instituição marcou significativamente a história da universidade no país, pela forma criadora e inovações com que a experiência se desenvolveu" (p. 25).

Ainda, de acordo com Fávero (2006), contrastando com a UDF, foi criada em 1937, a Universidade do Brasil, onde o governo autoritário de Vargas pôde definir suas regras de acordo com sua ideologia. Dentre as disposições presentes na lei de criação, pode-se citar a escolha do reitor e dos diretores da instituição pelo Presidente da República e a proibição de qualquer manifestação político-partidária, por parte de alunos e docentes, no campus da universidade. Fatalmente, uma universidade criada sob a égide de um governo ditatorial não poderia contar com regulamentos democráticos, cujos valores têm lastro na liberdade e na inquietação humana.

Os anos que sucederam o Estado Novo de Getúlio Vargas foram caracterizados por uma abertura democrática de caráter liberal. No período compreendido entre a segunda metade da década de 1940 e o início dos anos de 1960 houve a criação do sistema federal de educação superior, por meio da federalização de instituições estaduais, municipais e privadas. Além disso, foram criadas 18 instituições públicas e 10 privadas. Impulsionada pelo desenvolvimento capitalista que se estabeleceu no país, a educação superior privada consolidou-se, contando com legislações que contribuíram para essa tendência. O crescimento populacional e o aumento da demanda por esse nível de ensino fortaleceram essa curva 
ascendente. Sobre o pujante aumento nas matrículas do setor privado nesse período, Sampaio (2000) destacou que:

[...] o que se verifica no período de 1940-1960 são respostas do sistema de ensino superior às transformações pelas quais passava o país. Enquanto a população do Brasil passou de 41,2 milhões para 70,1 milhões, registrando crescimento de $70 \%$, as matrículas aumentaram em mais de três vezes no período. (p. 52)

Ao analisar os anos de 1950, percebe-se que o setor privado estava atento às mudanças da sociedade e, no que diz respeito à oferta de educação superior, manteve-se alerta às "novas exigências", ao contribuir para o forte crescimento de IES, nesse âmbito. (SOUSA, 2013). De acordo com o autor, o cenário econômico verificado nessa época, motivou "mudanças políticas e sociais expressivas que acabaram por interferir na demanda por ensino superior, ganhando força a relação da oferta público-privado nesse nível educacional” (p. 21).

O modelo de educação empreendido pelo governo de Juscelino Kubitschek (19561961), ao deflagrar uma política desenvolvimentista pautada pelo programa de metas, pode ser explicado pelos preceitos previstos na Teoria do Capital Humano ${ }^{29}$. A educação inseriu-se, nesse contexto, como uma maneira de capacitar pessoas para contribuírem com a implantação das indústrias de base previstas pelo presidente. Segundo Fonseca (2009) "a vinculação entre educação e economia ganhou destaque internacional pela emergência da teoria do capital humano e do enfoque de mão-de-obra (man-power approach)” (p. 157). A educação fora vista como meio de atender às demandas do mercado capitalista, com foco na capacitação técnica-profissional, em detrimento da formação crítica que possibilita ao indivíduo compreender sua realidade $\mathrm{e}$ as condições políticas-ideológicas às quais é submetido (FONSECA, 2009).

$\mathrm{Na}$ esteira desse processo, houve o crescimento das instituições privadas, impulsionado pela publicação da primeira Lei de Diretrizes e Bases da Educação, Lei n ${ }^{\circ} 4.024$ de 20 de dezembro de 1961(BRASIL, 1961), a qual previa a desobrigação de que a educação superior fosse ofertada, preferencialmente, em instituições universitárias. Segundo Sampaio (2000), a lei estabeleceu que o ensino superior pudesse "ser ministrado em estabelecimentos

\footnotetext{
${ }^{29}$ Como principal representante da Teoria do Capital Humano, Theodore William Schultz (1902-1988) fez diversas análises acerca do papel da educação para a formação do indivíduo e, principalmente, para sua função nas sociedades capitalistas. Para Silva e Puziol (2016), "essa teoria se intitula de grande valia para o sistema neoliberal; as políticas educacionais ficam conhecidas através de sua fundamentação econômica, e principalmente ligadas às diretrizes internacionais que estarão presentes no país" (p. 7).
} 
agrupados ou não em universidades, com a cooperação de institutos de pesquisa e centros de treinamento profissional.” (p. 55).

Vale destacar que a expansão do ensino superior, nesse período, sobretudo no setor privado, não significou uma democratização do acesso. O caráter elitista ainda era predominante, já que abarcava apenas uma parcela da população. A ausência de políticas públicas com o objetivo de reverter essa lógica ainda predominava, reafirmando o caráter excludente e contraditório da sociedade brasileira. Segundo Minto (2006), "os anos de 1950 e 1960 deram ensejo a uma série de reinvindicações populares, fruto das lutas por melhores condições de vida num país atrasado, marcado por uma forte concentração de renda e de terras, pela desigualdade social, pelo baixo nível educacional etc.” (p. 92).

Num paralelo com o período compreendido entre o Brasil-colônia e a primeira república, destaca-se que o elitismo e o privatismo continuavam a caracterizar a oferta de educação superior no país. Reservada às classes economicamente mais abastadas, a educação superior manteve a desigualdade social, a partir do momento em que os governos alijavam do seu acesso parcela considerável da sociedade brasileira. Na esteira desse processo, proliferaram-se as instituições privadas. Além das confessionais, comunitárias e filantrópicas, surgiram também as mercantis. O debate envolvendo as dimensões privatização e elitização marcou a história da educação superior no Brasil e aprofundou os desafios acerca da democratização do acesso.

As mudanças experimentadas no campo econômico fortaleceram a percepção de setores da sociedade sobre as mazelas evidenciadas pela forte desigualdade social, cada vez mais profunda e incômoda. Nesse sentido, emerge com força e importância um movimento que será determinante para as conquistas no campo da educação superior, sobretudo em relação à discussão da expansão e da democratização do acesso. O movimento estudantil, institucionalizado pela União Nacional dos Estudantes (UNE) na década de 1930, mais precisamente no ano de 1937, teve atuação destacada a partir dos anos de 1960, com progressiva importância a partir, sobretudo, da implantação do regime militar, em 1964.

Décadas depois, a UNE também foi fundamental para a discussão que envolveu a elaboração e implementação do Programa Universidade para Todos. Ciente de sua importância como sujeito que pratica a mediação entre os interesses estudantis e o Estado, a UNE exerceu papel substantivo na relação entre governo e sociedade, sendo capaz de influenciar a realidade, com avanços concretizados por políticas públicas educacionais, assim como aconteceu com o ProUni. 
Sobre o cenário de agitação e descontentamento evidenciados pela sociedade e catalisados pelo movimento estudantil, Durham (2003) fez uma breve análise e observou que

[...] a partir da década de 1950, [o período] é marcado por intensos conflitos sociais e um crescente envolvimento dos estudantes universitários em diversas lutas políticas, nas quais é forte a presença de diferentes partidos e militâncias de orientação marxista. [...] a modernização e a expansão capitalista do período agravaram a situação da população rural nas regiões de economia mais tradicional e colocaram em evidência a profundidade das desigualdades econômicas, sociais, políticas e educacionais do país, criando um clima de agitação generalizada (p. 201).

É certo que a UNE sempre esteve presente nos principais movimentos de contestação político-social do país, sobretudo a partir da década de 1950. No entanto, em alguns momentos de sua história foi acusada de ter sido cooptada pelo poder central. Por ser uma instituição reconhecidamente de caráter esquerdista, nada mais natural do que apoiar governos que se dizem, ideologicamente, identificados. Nesse sentido, ao longo do governo do Partido do Trabalhadores (PT), a partir de 2003, até hoje, a instituição vive essa crise de identidade e de legitimidade frente aos seus ideais, representados pela lógica da contestação e postura crítica, sobretudo em relação às ações do Estado.

Considerando as mudanças políticas, econômicas e sociais presentes na história do Brasil ao longo de todo o século XX e início do século XXI, pode-se dizer que a política de educação superior sempre esteve presente na pauta de discussão governamental. No entanto, o modelo de universidade, de políticas de acesso, de democratização e de permanência, assim como o debate em torno da prevalência de IES privadas em detrimento das universidades públicas, foram e continuam sendo pontos polêmicos, com grande peso ideológico.

No que diz respeito a esses desafios, vale destacar a importância da UNE, mesmo em momentos de desconfianças e críticas de alguns setores da sociedade. Tanto para propor, quanto para apoiar ou criticar, sua participação tem peso para a formulação e implantação de qualquer política pública para o setor. Como destacado, sua contribuição foi bastante importante para o governo ao participar dos debates envolvendo a implementação do ProUni, no momento em que vozes dissonantes pressionavam-no.

Os defensores da oferta pública de educação superior acusavam o governo de estar dando mais um passo para a privatização da oferta desse nível educacional. Pois, um programa que privilegia o setor privado, com isenções fiscais para promover o acesso a cursos de graduação não era visto com bons olhos pelos representantes do setor público. Nesse 
sentido, compreender a motivação que transformou as instituições privadas em protagonistas na oferta desse nível educacional fez-se necessário.

Apesar de remontar ao final do século XIX o surgimento do setor privado como alternativa para a oferta de educação no país, foi a partir da segunda metade do século XX que essa tendência se consolidou. O governo militar criou as condições necessárias para que as instituições privadas se tornassem as principais responsáveis pela oferta desse nível de educação no país.

\subsection{Relação público-privado: da ditadura militar (1964 a 1985) ao primeiro mandato do governo Dilma Vana Rousseff (2011-2014)}

Entender a contradição que cerca o tema da relação público-privada faz-se necessário para melhor compreender o contexto das políticas educacionais de nível superior. Com a implantação do regime militar, a partir do golpe de Estado em 1964, o debate é aprofundado, tendo como pano de fundo a consolidação da oferta de cursos de graduação pelo setor privado.

Para ilustrar o momento em que a iniciativa privada passou a ser a protagonista na oferta de ensino superior no país, segue o gráfico 2. Vê-se que a partir da década de 1970, as matrículas nas instituições públicas apresentaram uma redução em relação à década anterior. Em movimento oposto, o setor privado passou a ter mais estudantes nesse período. Situação que, até os dias atuais, não mais se alterou.

Gráfico 2 - Evolução das matrículas em estabelecimentos públicos e privados no ensino superior, 1933-1980

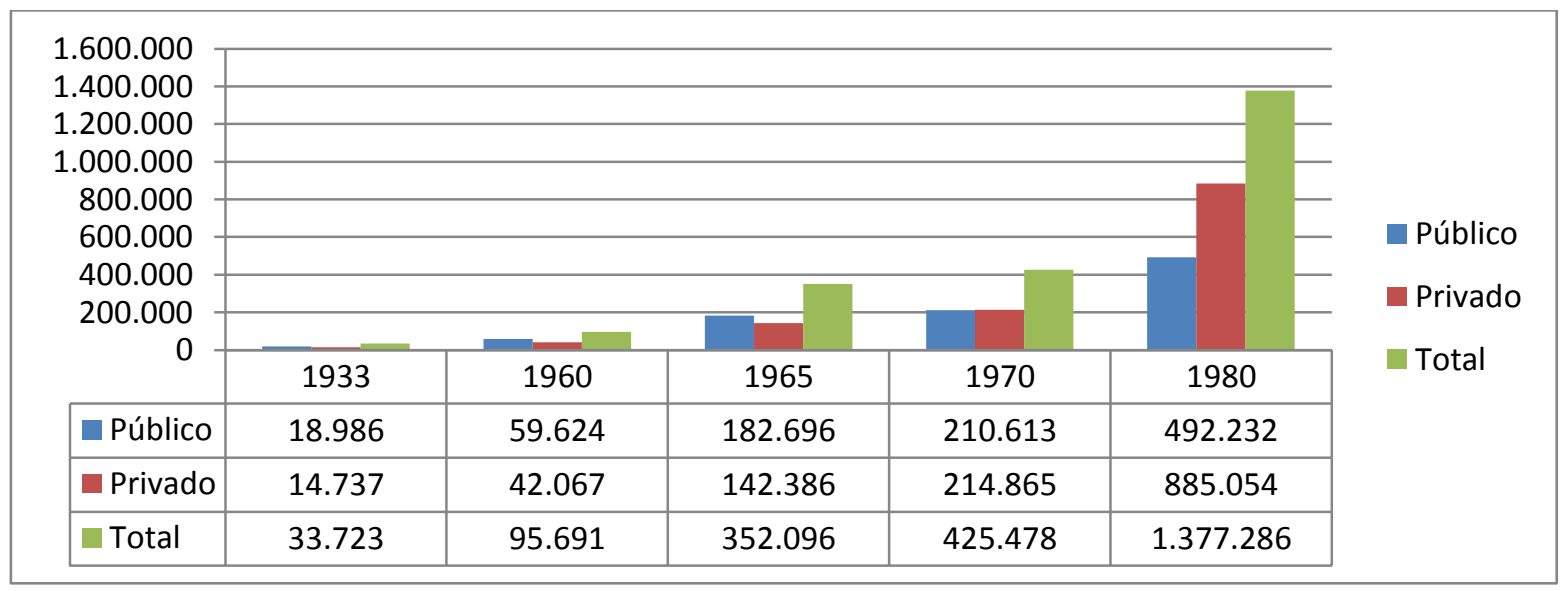

Fonte: Durham (2003, p. 199). 
Percebe-se no gráfico 2 que o setor público foi perdendo espaço, gradativamente, ao longo dos anos. Em 1933, sua representatividade correspondia a 56,3\% das matrículas. No setor privado, a taxa era de 43,7\%. Esse cenário foi sendo alterado até que na década de 1970 as instituições privadas passaram a ser responsáveis pela maior parte das matrículas desse nível de ensino, com taxa de 50,5\%. Já as públicas, nesse mesmo ano, apresentaram um índice de 49,5\%. Daí em diante, essa tendência se consolidou e o setor privado não mais perdeu o protagonismo, em termos quantitativos, no que tange à oferta de educação superior no Brasil.

Outro dado importante diz respeito ao incremento no número de matrículas total (público e privado) ocorrido no decorrer da década 1970, culminando em um número três vezes maior de estudantes na graduação no início da década de 1980 . O crescimento da economia empreendido pelos militares, denominado de "milagre brasileiro", foi uma das explicações para esse fenômeno. Diante do quadro otimista da época, superado alguns anos depois, a demanda por mão de obra especializada e por maior qualificação passou a ser a tônica. Segundo Durham (2003),

[...] o regime militar logrou promover, na década de 1970, um grande desenvolvimento econômico, o chamado milagre brasileiro. Essa enriqueceram, $[\mathrm{sic}]$ alimentando a demanda por ensino superior (p. 208).

Comparativamente, pode-se dizer que cenário parecido foi vivenciado pela população brasileira a partir da segunda metade da década de 1990 com o governo de Fernando Henrique Cardoso (1995-2002) e, na sequência, a partir do primeiro mandato do governo de Luiz Inácio Lula da Silva (2003-2006). Impulsionada pelo fortalecimento da economia, a demanda por maior qualificação fez-se presente e o sistema de educação superior precisou adequar-se a esse novo cenário.

A par dessa realidade e pautado pela meta do PNE (2001/2010), de aumentar a taxa de escolaridade de nível superior, e ainda disposto a regular as instituições privadas, que se beneficiavam de isenções fiscais, o governo Lula criou o ProUni. Pode-se considerar que esse Programa atingiu um objetivo, relativamente abrangente, ao conseguir agradar parte da sociedade, do próprio governo e do setor privado, ficando de fora dessa equação, os defensores da educação pública estatal.

No final da década de 1960, mais precisamente no ano de 1968, o governo militar viu-se obrigado a realizar uma reforma no ensino superior devido à pressão da população, sobretudo dos jovens, que demandava mais acesso a esse nível educacional. A UNE exerceu forte pressão política nesse período e transformou-se num sujeito importante na relação com o 
Estado. Ao analisar a evolução do número de instituições de educação superior privadas e a relação com a realidade econômica e social do país naquele período, Durham (2003) explicou que

[...] o aumento da demanda por ensino superior está associado ao crescimento das camadas médias e às novas oportunidades de trabalho no setor mais moderno da economia e da tecno-burocracia estatal. Para atender à demanda massiva que se instaurara, o setor público precisava criar não apenas outros tipos de cursos, mas outros tipos de instituições [...] Como isso não ocorreu, persistiu no Brasil uma demanda que o sistema público foi incapaz de absorver. O setor privado foi capaz de fazê-lo porque se concentrou na oferta de baixo custo e no estabelecimento de exigências acadêmicas menores tanto para o ingresso como para o prosseguimento dos estudos até a graduação. (p. 209).

O trecho apresentado parece, paradoxalmente, tratar-se da realidade recente, ao destacar o aumento de demanda por educação superior como consequência de mudanças significativas no país, especialmente as desencadeadas pelo cenário econômico, que estimula a procura por esse nível de formação. Associado ao crescimento das instituições privadas e de suas estratégias de oferta de curso de graduação, a realidade educacional desse nível de ensino, no final dos anos 1960, assemelha-se, de certa forma, à experimentada a partir da década de 1990, em que nova expansão do setor privado ocorre, quando do governo de Fernando Henrique Cardoso.

Seguindo essa lógica expansionista, o ProUni, implementado no governo de Luiz Inácio Lula da Silva, é um Programa que objetivou atender, via setor privado, à forte demanda por educação superior. Além disso, contribuiu para a discussão envolvendo a relação públicoprivado, na medida em que suscitou a dúvida sobre sua capacidade de democratizar o acesso à educação superior, efetivamente - assunto que será visto no capítulo 2.

Sobre o modelo de ensino superior, empreendido a partir da Reforma promovida pelo regime militar, Martins (2009) explicou que "emergiu de uma constelação de fatores complexos, entre os quais destacam, num primeiro momento, as modificações ocorridas no campo político nacional em 1964 e seu impacto na formulação da política educacional” (p. 18). O diagnóstico realizado por grupos de trabalho ${ }^{30}$ criados pelo governo estabelecia a

\footnotetext{
${ }^{30}$ Além do fundamental papel da UNE para a discussão do novo modelo de universidade que ora estava sendo travada no limiar dos anos de 1960, os referidos grupos de trabalho - GT subsidiaram o documento que deu origem à Reforma Universitária de 1968. Fávero (2006) e Vieira (2008) descrevem o papel que cada grupo ou relatório teve para a configuração desse modelo propugnado pelos militares e concretizado pela Lei $n^{\circ} 5$. 540 de 1968. Foram eles: 1) Acordos internacionais - MEC/USAID (United States Agency for International Development que deram origem a dois relatórios: Plano Atcon e o Relatório EAPES (Equipe de Assessoria ao
} 
necessidade de formação de quadros que atendessem ao desenvolvimento do país. Nesse sentido, o setor privado atendia melhor às demandas do Estado e da própria sociedade. As universidades públicas se tornaram alvo do controle ideológico e do autoritarismo, próprios dos regimes militares.

Os efeitos e o caráter da reforma implementada pela Lei $n^{\circ} 5.540$, de 28 de novembro de 1968 (BRASIL, 1968), são ainda hoje discutidos. Partindo do pressuposto de que toda política pública tem o peso ideológico do Estado, que reflete o governo que a elaborou, podese dizer que a Reforma Universitária de 68 só saiu do papel devido ao reduzido espaço para o exercício do contraditório, típico de um Estado autoritário. Segundo Vieira (2008), sendo “as leis expressão de uma ambiência política autoritária ou democrática, sua configuração acaba por retratar elementos dos contextos em que são concebidas. Nos regimes mais fechados, a dinâmica das grandes reformas encontra solo fértil”' (p.3). Talvez por isso, tenha sido possível a concretização de tal reforma.

Vale destacar, no entanto, que o processo de discussão, elaboração e implementação da política, em que pese o ambiente autoritário da época, "ecoa” ainda hoje. Vieira (2008) explica que esse "eco" produzido, pode ser explicado, em parte, pelo contexto de agitação político-social e ideológica que, não só o Brasil, mas o resto do mundo passava, naquele momento ${ }^{31}$. Considerando os mais de $40 \operatorname{anos}^{32}$, desde a promulgação da lei que a instituiu, a Reforma Universitária de 1968 contribui para a discussão acerca dos desafios relacionados ao acesso à educação superior e o papel que o setor privado ocupa nesse debate.

Em seus artigos $2^{\circ}$ e $4^{\circ}$, a Lei $n^{\circ} 5.540 / 1968$ dispõe sobre o modelo e a forma da oferta de ensino superior no país a partir daquela data. Tais artigos referem-se às instituições públicas e privadas, numa tentativa de normatizar as atividades desenvolvidas pelas diferentes esferas. Num dos pontos principais da reforma, a prática da pesquisa é tratada no primeiro artigo, como um dos objetivos do ensino superior. Essa indissociação do ensino e pesquisa na oferta desse nível de educação vai, anos depois, subsidiar muita discussão, a partir da admissão de novos modelos institucionais, onde a oferta de cursos de graduação não mais

Planejamento do Ensino Superior); 2) Relatório Meira Matos e 3) Relatório Geral do Grupo de Trabalho da Reforma Universitária - GT criado pelo Decreto nº 62.937 de 02.07.1968.

${ }^{31}$ Tais agitações tiveram as manifestações de estudantes na França, de intelectuais em países da Europa oriental e movimentos de luta em defesa de direitos civis e pela paz, nos Estados Unidos, como os principais exemplos internacionais. No Brasil, o regime militar caminhava para sua fase mais dura e violenta. Em 13 de dezembro de 1968 o Ato Institucional n 5 (AI -5) foi decretado e tal medida deixou claro o caráter autoritário daquele governo, que resultou no fechamento do Congresso Nacional (VIEIRA, 2008).

${ }^{32}$ O texto: "Reforma Universitária - ECOS", de 1968, foi apresentado por Sofia Lerche Vieira na $31^{\text {a }}$ Reunião da Anped, realizada em 2008, portanto, 40 anos depois da referida reforma. 
estaria atrelada à prática da pesquisa. A respeito da lei da reforma universitária de 1968, segue o artigo que faz referência ao setor privado.

Artigo $2^{\circ} \mathrm{O}$ ensino superior, indissociável da pesquisa, será ministrado em universidades e, excepcionalmente, em estabelecimentos isolados, organizados como instituições de direito público e privado. [...]

Artigo $4^{\circ}$ As universidades e os estabelecimentos de ensino superior isolados constituir-se-ão, quando oficiais, em autarquias de regime especial ou em fundações de direito público e, quando particulares, sob a forma de fundações ou associações (BRASIL, 1968).

Apesar de a lei fazer referência ao setor privado como uma excepcionalidade, para oferta de cursos de graduação, Sousa (2013) chamou a atenção para o que ele identificou como "inversão desta proposição", considerando que as instituições privadas passaram a ser a regra e não a exceção do sistema de ensino superior da época. Ainda, segundo o autor, a Constituição promulgada um ano antes da reforma, já previa "apoio estatal à iniciativa privada no ensino, uma vez que [...] disponibilizou ajuda técnica e financeira dos poderes públicos ao segmento privado, destacando-se a modalidade de bolsas de estudo" (p. 25).

Assim dizia a Constituição de 1967, no artigo 168, §3º inciso III: "Sempre que possível, o poder Público substituirá o regime de gratuidade pelo de concessão de bolsas de estudo, exigido o posterior reembolso no caso de ensino de grau superior;" (BRASIL, 1967). Depreende-se daí, que a relação público-privado é constitucionalmente estabelecida, servindo de embrião para políticas de acesso à educação superior, com financiamento público em instituições privadas, como é o caso do ProUni, implementada no século XXI.

Além disso, o papel regulador e avaliador do Estado em relação à iniciativa privada já estava previsto na primeira Lei que fixou as Diretrizes e Bases da Educação Nacional, Lei n 4.024 de 27 de dezembro de 1961. No título que tratou "Dos Sistemas de Ensino", o artigo 14 dizia que é "da competência da União reconhecer e inspecionar os estabelecimentos particulares de ensino superior" (BRASIL, 1961). Essa previsão contribuiu para o reconhecimento da incipiente parceria público-privada que se consolidaria algumas décadas depois.

Ademais, Sousa (2003) destacou que, com a promulgação da LDBEN/1961, houve um aumento de demanda por curso de graduação, ao conceder "plena equivalência a todos os cursos de grau médio para entrada no nível superior” (p. 22). Isso provocou maior procura por esse grau de formação e, consequentemente, motivou a pressão por mais vagas nessas instituições de ensino. Esse movimento se encorpou e resultou na reforma implementada em 
1968 que, objetivamente, catapultou o setor privado a protagonista da oferta de educação superior no país.

Vale ressaltar que todo esse diploma legal, envolvendo constituições e leis ordinárias, mostrara a tendência do Estado brasileiro em dividir com o setor privado a oferta pela educação, em todos os níveis. A partir da década de 1970, o país não só passou a dividir mais fortemente a oferta de educação superior com a iniciativa privada, como essa passou a ser a principal ofertante de cursos de graduação.

Para Sampaio (2000) "o setor privado crescia em detrimento do setor público, em virtude da insuficiência do último e de uma política deliberada do Governo, com objetivo de transferir o atendimento da demanda crescente por formação superior ao setor privado” (p. 65). Apesar da Reforma Universitária de 1968 ter objetivado conter a expansão no número de instituições privadas, isso não se concretizou e o protagonismo do setor se manteve. Segundo Sousa (2013) "as instituições isoladas proliferaram de maneira expressiva, apesar de o próprio poder público reconhecer aspectos preocupantes em relação a essa opção" (p. 24).

O setor privado encarregou-se de atender à demanda crescente por ensino superior, com vistas ao mercado de trabalho e à formação de profissionais liberais. Nesse sentido, a universidade pública assumiu ainda mais seu caráter elitista por ter sua oferta vinculada à indissociação entre ensino, pesquisa e extensão. Apesar de uma das reinvindicações do movimento estudantil da década de 1960 ter sido a ampliação do acesso à universidade, isso não se deu, significativamente, nas instituições públicas, senão nas privadas.

Sampaio (2000) destacou que o caráter diferenciado da educação superior ofertada pelo setor público limitou sua expansão e abriu "ao setor privado, a oportunidade de atender à demanda de massa que o Estado não conseguia absorver” (p. 69). Não significa dizer que as instituições privadas de educação superior estavam abertas à população das camadas mais populares. O acesso a essas IES também era limitado, sobretudo, devido ao valor de suas mensalidades. Até o final do regime militar, prevalecia o acesso restrito a esse nível de educação, mesmo com a crescente oferta, protagonizada pelo setor privado.

Diante dessa realidade, questiona-se alguns argumentos contrários ao ProUni, quando se constata que a hegemônica participação das instituições privadas na oferta de educação superior remonta a décadas passadas. Dentre as posições contrárias, está a de que a contrapartida fiscal dada às instituições que aderiram ao Programa poderia ser revertida em investimento nas IFES. Sobre essa polêmica, um dos gestores do MEC, entrevistados para esta pesquisa, destacou que 
[...] o ProUni representa cerca de oitocentos milhões de renúncia fiscal. Hoje, na ponta do lápis, custa em torno de cem reais por mês, por aluno, baratíssimo para o governo, o ProUni é baratíssimo [...] é oitocentos milhões num orçamento de vinte e sete bi, que é o orçamento das federais, das universidades públicas federais, ou seja, num tô nem incluindo os aposentados aqui, com os aposentados dá 45 bi. É uma gota no oceano, é outra escala. Não teria impacto nenhum no sistema federal. Então, a crítica [...] que se fazia de que se pegasse o dinheiro do ProUni lá em 2005 e jogasse nas federais, isso ia resolver todo o problema, [é] conversa; isso é pra quem não olhou os números [...] (GM1 - informação verbal)

Mesmo partindo do princípio de que o valor que o Estado deixa de recolher com as taxas e contribuições fiscais das IES não poderiam ser redirecionadas às IFES e que, caso pudessem, não impactaria nos orçamentos dessas de forma significativa, como observou GM1, críticos do Programa atribuem ao ProUni uma iniciativa deliberada do governo de fortalecer as instituições privadas em detrimento das públicas.

Ressaltando o papel da iniciativa privada, vale destacar que o aumento da oferta de vagas por essas instituições estava associado à crescente demanda motivada por duas realidades. Uma ligada à incapacidade das instituições federais de educação superior em absorver a população aprovada nos vestibulares, chamada de "excedente", visto que sobravam candidatos aprovados e faltavam vagas para admiti-los. A outra ligada à realidade econômica do país, que, após a derrocada do "milagre econômico" empreendido pelos militares, fez com que parte da classe média não visse outra saída para ascender socialmente, não fosse a conclusão de uma graduação (MARTINS, 2009).

Com o foco no dilema envolvendo os setores público-privado e a Reforma Universitária de 1968, Fávero (2006) analisou o papel da UNE nessa discussão e destacou que

[...] a participação do movimento estudantil se dá de forma muito densa, o que torna difícil analisar a história do movimento da Reforma Universitária no Brasil sem que seja levada em conta essa participação. Dos seminários e de suas propostas fica evidente a posição dos estudantes, através da UNE, de combater o caráter arcaico e elitista das instituições universitárias (p.29).

A importância do movimento estudantil foi e continua sendo inquestionável, tanto para a defesa das questões essencialmente educacionais, quanto para as de diferentes matizes sociais. Nesse sentido, a partir da segunda metade da década de 1960 o referido movimento recrudesceu pela defesa do direito à educação superior pública e de qualidade. Iniciou-se aí um período de lutas e pressões junto a governos que se sucederam, seguindo a lógica da intolerância, da falta de diálogo e até mesmo da violência. Foram os anos duros da ditadura 
militar (1964-1985) que, contraditoriamente, permitiram, a partir da Reforma Universitária de 1968, alguns avanços em relação ao modelo de universidade existente no país.

No entanto, a pressão exercida por esse movimento não foi suficiente para construir alternativas que reduzissem as desigualdades educacionais e contradições presentes na sociedade brasileira. Na medida em que a oferta de educação superior manteve-se reservada às classes mais favorecidas economicamente e que o arranjo institucional, definido a partir dos anos 1960, consolidou a hegemonia do setor privado, pode-se considerar que o modelo excludente permaneceu inalterado. Isso pode ser confirmado ao se observar as baixas taxas de escolaridade que foram mantidas, ao longo das décadas. Afinal, quando o ProUni foi lançado, em 2004, já em pleno século XXI, a taxa de escolarização bruta na educação superior brasileira encontrava-se em 17,3\% e a líquida, em 10,4\% (INEP, 2005). Dados recentes mostram que a política de bolsas do Programa promoveu uma relativa melhora nesses índices e ainda contribuiu para aumentar o ingresso de negros nas IES, na medida em que suas ações foram direcionadas às minorias socioeconômicas e étnico-raciais. MEC(2015a), MEC (2015b), MEC(2015c), INEP(2014), RISTOFF(2014). No entanto, na visão desta autora, enquanto o setor privado ${ }^{33}$ existiu apenas como opção a quem tinha condições de pagar, o modelo excludente não sofreu impactos relevantes.

No que diz respeito às instituições privadas, vale chamar a atenção para outro fenômeno ocorrido nesse período. O aumento do setor educacional empresarial que tem como foco principal o lucro. Esse movimento determinou a distinção entre instituições com fins lucrativos, daquelas sem fins lucrativos e, anos depois, essa diferenciação institucional da rede privada se consolidou com a abertura do capital dessas IES na bolsa de valores, com a fusão de instituições e, também, com a criação de oligopólios educacionais. É a educação sendo tratada essencialmente como negócio. Ao analisar essa tendência privatista, Durham (2003) explicou como se deu esse movimento na década de 1970. Segundo ela,

\footnotetext{
33 As instituições privadas de ensino, de acordo com o art. 20 da LDBEN podem ser: I - particulares em sentido estrito, assim entendidas as que são instituídas e mantidas por uma ou mais pessoas físicas ou jurídicas de direito privado que não apresentem as características dos incisos abaixo; II - comunitárias, assim entendidas as que são instituídas por grupos de pessoas físicas ou por uma ou mais pessoas jurídicas, inclusive cooperativas educacionais, sem fins lucrativos, que incluam na sua entidade mantenedora representantes da comunidade;

III - confessionais, assim entendidas as que são instituídas por grupos de pessoas físicas ou por uma ou mais pessoas jurídicas que atendem a orientação confessional e ideologia específicas e ao disposto no inciso anterior; IV - filantrópicas, na forma da lei. (BRASIL, 1996).
} 
[...] as instituições privadas de ensino superior haviam se tornado, de fato, um grande negócio. Parte dos novos estabelecimentos de ensino foi criada pela transformação de escolas de ensino médio. Mas a lucratividade dos empreendimentos atraiu também todo um novo conjunto de empresários, sem compromissos anteriores com a educação. Direcionados pelo objetivo de ampliar a lucratividade do empreendimento pela captação da demanda disponível, o setor privado passou a ser governado pelo mercado [...]. A expansão desse segmento do setor privado, que podemos chamar de empresarial, se orientou para a satisfação dos componentes mais imediatos da demanda social, que consiste na obtenção do diploma. [...] O sistema privado dividiu-se internamente entre um segmento comunitário ou confessional não lucrativo - que se assemelhava ao setor público - e um segmento empresarial (p.209-210).

A autora ressaltou que esse modelo de instituição atenderia a uma demanda social cuja preocupação seria adquirir um diploma que atendesse às necessidades do mercado e que possibilitasse conquistar um lugar no mercado de trabalho. Segundo a mesma, essa característica estaria ligada a uma herança cartorial brasileira que ligava o certificado de nível superior à garantia de um emprego regulamentando.

Além disso, pode-se dizer que essa tradição atendeu também aos preceitos da Teoria do Capital Humano, que tem a educação como meio para capacitar o indivíduo ao atendimento das necessidades impostas por uma sociedade globalizada. As carências de mão de obra precisam ser supridas por pessoas qualificadas para o mercado de trabalho, daí a educação deixar de ser vista como um agente formador de mentes criativas para ser um meio de capacitação para suprir o setor produtivo, sob os moldes do sistema capitalista (SILVA; PUZIOL, 2016).

Sobre essa expansão, protagonizada pelas IES privadas de caráter utilitarista, Minto (2006) chamou o fenômeno de "trama privatizante", que caracterizou a educação superior privado no Brasil, entre os anos de 1970 a 1980. Em relação a esse período, observa-se o crescimento no número das instituições públicas e privadas, de acordo com a tabela de número 1 , a seguir.

\section{Tabela 1 - Estabelecimentos de ensino superior segundo dependência administrativa e natureza acadêmica - 1971-1980}

\begin{tabular}{c|c|c|c|c|c|c|}
\hline $\begin{array}{c}\text { Natureza } \\
\text { Acadêmica }\end{array}$ & \multicolumn{2}{|c|}{ Universidades } & \multicolumn{2}{|c|}{ Estabelecimentos Isolados } & \multicolumn{2}{c|}{ Federações } \\
\hline Ano & Públicas & Privadas & Públicos & Privados & Públicas & Privadas \\
\hline 1971 & 31 & 16 & 81 & 511 & $(---)$ & $(----)$ \\
\hline 1975 & 36 & 21 & 92 & 711 & $(---)$ & $(----)$ \\
\hline 1980 & 43 & 22 & 65 & 643 & 1 & 19 \\
\hline
\end{tabular}

Fonte: Sampaio (2000, p. 71) - adaptado. 
Conforme consta na tabela, o setor privado iniciou a década de 1970 com 16 universidades e 511 estabelecimentos isolados, fechando o período de dez anos com 22 universidades privadas e 643 instituições de outra natureza, sendo que essas tiveram seu número reduzido, ao constatar que, em 1975, eram 711 estabelecimentos isolados.

Mancebo (2015) chamou a atenção para essa tendência privatista da educação superior, e destacou que esse fenômeno não é exclusividade do Brasil. Trata-se, na verdade, segundo a autora, de consequência de um processo por ela chamado de "mundialização da

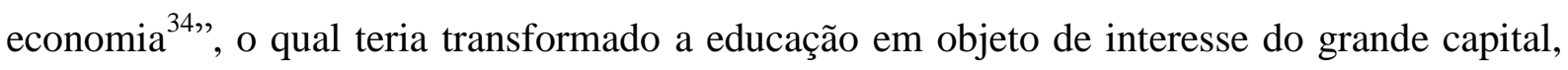
sobretudo nos países asiáticos e anglo-saxônicos, como os Estados Unidos. Para exemplificar, ela citou o período de 1995-2012 em que destacou o menor crescimento das matrículas no setor público $(170,84 \%)$ em relação às da rede privada $(385,32 \%)$ sendo esta, especialmente no segmento das IES particulares.

A análise dessa relação evidenciada entre o setor público e o privado fez-se relevante, devido ao objeto dessa pesquisa, que tem como um dos focos de análise esse binômio. O ProUni não existiria sem as instituições privadas de educação superior, sejam elas com finalidade lucrativa ou não. O governo Lula (2003-2010), ao decidir expandir a oferta de graduação, buscou nesse setor um dos caminhos para o desafio de ampliar o número de matrículas na educação superior. Exemplo disso é a criação do ProUni, que financia vagas públicas em instituições privadas a partir da isenção fiscal.

Sobre a contribuição do setor privado para a expansão do acesso à educação superior no país, segue a fala de três gestores do MEC que foram entrevistados para essa pesquisa. $\mathrm{O}$ primeiro destacou que

[...] a importância de o país ter energias criativas a serviço do país, do desenvolvimento é tão grande pra nós por causa da taxa de escolarização que é muito pequena historicamente. Então, o tamanho do desafio, ele exige a participação de todos, não dá pra ficar restrito só ao setor público. [...] como é que o setor privado contribui? Ele contribui da mesma maneira que o setor público num projeto que é [...] nacional; que tem uma demanda enorme. Num país onde só na época, em 2003, por exemplo, $9 \%$ de cada 100 jovens, de 18 a 24 anos, estavam na educação superior, se precisava disso; se precisava dos dois e hoje ainda precisa, porque hoje nós temos [...] 20 de cada 100. Significa que 80 nós não aproveitamos plenamente o potencial. Nenhum país aproveita 100, mas a maioria dos países já aproveita 40 há muitos anos, há décadas. (GM1 - informação verbal).

\footnotetext{
34 Termo que talvez possa ser substituído por “mundialização do capital”, utilizado por Chesnais (1997), quem fez uma análise sobre o cenário econômico mundial sob a égide do capitalismo financeiro.
} 
A segunda gestora acredita que, nessa relação entre o setor público e o setor privado, o governo precisa criar uma maneira de reequilibrar as forças, considerando o tamanho da representação de cada setor na oferta de vagas nos cursos de graduação no país. Nesse sentido ela disse que

[o governo] tem o desafio de fazer esse equilíbrio, de melhorar esse equilíbrio entre as vagas públicas e privadas, mas eu acho que a gente ainda vai ter que, por um bom tempo, contar com o setor privado pra fazer essa expansão, o que eu não vejo, necessariamente, como um problema desde que se imprima e se exija qualidade e compromisso com os objetivos do país, com o desenvolvimento do país. (GM3 - informação verbal).

Por fim, ainda analisando o papel do setor privado para o processo de expansão de vagas na educação superior por meio do ProUni, a gestora do Instituto Nacional de Estudos e Pesquisas Educacionais Anísio Teixeira, uma autarquia vinculada ao MEC, afirmou que

No momento em que a gente estabelece a política do ProUni, ela é uma vaga pública no setor privado. Ela é uma articulação do setor público para que esse estudante possa estar no setor privado. Então, você acaba promovendo uma expansão pública, no segmento privado. Quando você analisa que eu acho que mais de $40 \%$ dos estudantes hoje têm acesso a essas políticas, ao ProUni, você tá garantindo que você não tem condições de ampliar a rede pública, mas você diz não, você pode acessar a educação superior privada com recurso que é público. (GM2 - informação verbal).

Percebe-se, portanto, pelos discursos dos três gestores, que ambos consideram importante a participação das instituições privadas no processo de expansão do acesso às IES. Mais do que isso, acreditam ser indispensável, partindo do pressuposto de que sem essa presença, seria impossível avançar em relação às taxas de escolarização desse nível de educação que é consideravelmente baixa. No entanto, essa realidade, como destaca GM3 não precisa ser eterna ou irreversível. Na sua visão, o governo precisa criar formas de melhor distribuir a participação dessas instituições. Depreende-se daí, que a única forma disso acontecer, é aumentando o investimento do setor público, com criação de novas vagas nas IFES.

Sobre a relação público-privado no governo de FHC (1995-2002) há de ressaltar sua opção pelo movimento expansionista em que prevaleceu a grande abertura de instituições e cursos, exclusivamente no setor privado. Sem muita supervisão, sua política não foi direcionada ao atendimento de uma demanda específica, regulada aos reais interesses da 
sociedade. O Brasil atravessava grandes mudanças econômicas empreendidas pelo próprio governo, como a estabilização da moeda (Plano Real), mas carecia de políticas educacionais que visassem a real e necessária democratização do acesso à educação superior.

Ao analisar essa relação estabelecida entre o público e o privado no que diz respeito à educação, no governo de FHC, Chaves (2005) descortinou o caráter do modelo implementado, à luz dos ditames empreendidos pelas instituições multilaterais. Para ela, a

[...] precária delimitação entre as esferas do público e do privado na relação entre Estado e sociedade civil se desdobrou nas políticas educacionais, desvelando o caráter ideológico privado assumido pelo Estado brasileiro ao longo da história da educação superior. Foi, entretanto, no período de 1995 a 2002, por meio da edição de uma série de instrumentos normativos, que o governo brasileiro promoveu uma reforma na educação superior, sob a orientação dos organismos internacionais, especialmente o Banco Mundial. As bases epistemológicas dessa reforma tinham como pressuposto a reconceituação/ressignificação do público e do privado, com fundamento básico no mercado. (p. 9)

O governo FHC seguiu o ideário neoliberal, sugerido por instituições como o Banco Mundial (BM), e privilegiou o setor privado em detrimento do público no que diz respeito às IES. A expansão das instituições privadas em relação às públicas deixou evidente a política educacional do então ministro da educação, Paulo Renato de Souza. Para Silva (2012), sua opção deveu-se à concepção gerencialista de Estado feita por seu governo, em que foi implementado um Estado gestor, com o objetivo de dividir com a sociedade a responsabilidade pelo gerenciamento das políticas sociais. Com isso, promoveu-se a consequente redução do papel do Estado junto às políticas sociais e econômicas. Para o autor, as "forças hegemônicas ligadas ao mercado impuseram suas diretrizes não só à política econômica e à reestruturação da gestão pública nacional, mas também aos termos da formação humana". (p. 34).

Ainda sobre essa relação evidenciada entre o público e o privado, pode-se dizer que no governo Lula, esse binômio não foi superado, ou seja, não houve uma ruptura no modelo adotado pelo seu governo, em relação à oferta de cursos de graduação. Significa dizer que, assim como FHC, o governo do presidente em questão também atendeu, de certa forma, aos preceitos defendidos pelos organismos internacionais. O ProUni foi um Programa pensado para aumentar o acesso da população carente à educação superior, por meio do setor privado. No entanto, para os críticos, sobretudo os representantes das universidades públicas, essa política seguiu a lógica de fortalecimento do setor privado em detrimento do público. Para explicar essa semelhança entre esses governos, no que diz respeito à política de educação 
superior, destacando o projeto de reforma universitária do governo Lula, Ferreira (2012) apontou que a

[...] busca de um consenso para o campo das políticas da educação superior foi desenvolvida tanto pelo governo FHC quanto pelo governo Lula, em consonância com parte das diretrizes emanadas pelos organismos multilaterais, procurando-se naturalizar a inexistência da contraposição entre os planos públicos e privados; a defesa do papel do Estado como regulador e controlador da prestação de contas das IES; a ciência e o conhecimento a serviço da economia, dentre outros. Portanto, a reforma da educação superior efetivada no governo Lula optou pela continuidade de várias diretrizes adotadas pelo governo FHC, ao priorizar como papel fundamental das universidades a perspectiva do seu retorno econômico para a sociedade brasileira; ao incentivar a diferenciação e a competição das universidades federais por recursos e na gestão estratégica; ao apoiar parcerias públicoprivadas, inovação tecnológica e venda de serviços; ao conferir centralidade aos sistemas de avaliação e regulação. (p. 465).

No entanto, apesar do forte crescimento empreendido pela esfera privada, no período pós-redemocratização, pode-se dizer, sobretudo no governo Lula, que o setor público também expandiu, principalmente após a implementação do Reuni, já citado neste trabalho. Semelhante movimento aconteceu nos anos do governo militar, durante o qual, apesar do caráter privatizante em relação à política de ensino superior, o setor público também aumentou. Segundo Martins (2009) "seria incorreto afirmar que o ensino público não cresceu, uma vez que, no período de 1967 a 1980, suas matrículas passaram de 88 mil para aproximadamente 500 mil estudantes, registrando um crescimento da ordem de 453\%" (p. 22).

O setor privado, no entanto, ocupou lugar de destaque nessa expansão, sobretudo pela diversificação institucional. Oliveira (2013) ressaltou que o governo se imbuiu de um discurso voltado à justiça social, para reduzir o papel do Estado nas políticas de acesso à educação superior pública. Segundo ele,

[...] o Estado passa a valorizar a iniciativa privada ou instituições filantrópicas e de benemerência. Paulatinamente, ele vai desobrigando-se da educação pública, procurando, ao mesmo tempo, fórmulas para eliminar a gratuidade, sobretudo, do ensino superior. O discurso do governo é o de que eliminar a gratuidade, seria adotar um critério mais justo e igualitário, pois são os estudantes ricos que têm acesso ao ensino superior (p. 285).

Ainda segundo o autor, o movimento expansionista do acesso à educação superior, durante o regime militar, teve um perfil "liberal autoritário, conservador, desmobilizador e 
excludente" conduzindo um "processo crescente de vulgarização, deterioração, controle e privatização" (p. 285). Tal perfil, destacado por ele, coaduna com o modelo de estado, implementado pela ditadura, que pretendia controlar a sociedade, cerceando as liberdades individuais e os direitos sociais, limitando o acesso a uma educação crítica, voltada ao fortalecimento da cidadania. No entanto, o perfil dessa política educacional do período militar, analisada por Oliveira (2013) faz lembrar, sobremaneira, o então ministro da educação de FHC, Paulo Renato de Souza, ao dar um verniz de justiça social aos preceitos neoliberais estabelecidos pelos organismos internacionais, no trato da política pública de educação superior.

Na contramão da expansão empreendida nos anos de 1970, pode-se dizer que a década de 1980 foi marcada por uma retração na demanda por educação superior. Para Durham (2003) “o crescimento dos anos de 1970 só foi possível pela existência de uma demanda reprimida de antigos egressos do ensino médio e daqueles que o tinham completado em cursos supletivos" (p. 213).

A redemocratização política do país promoveu uma alteração no cenário da educação superior e a iniciativa privada mitigou, devido à diminuição da procura pela formação desse nível de educação e do número de alunos formados no ensino médio. Segundo a autora, "não havia mais candidatos em número suficiente para preencher todas as vagas existentes no sistema privado" (p. 214). Com essa inflexão na expansão do setor privado, surgem as vagas ociosas, que, segundo os críticos do ProUni, vão ser uma das explicações para a criação do Programa. Segundo eles, um dos objetivos dessa política foi o de preencher as referidas vagas, criadas a partir de uma ampliação "com fortes indícios de exaustão” (SOUSA, 2010, p. 13).

Ratificando a análise relativa à retração do acesso ao ensino superior na década de 1980, Sousa (2014) destacou o movimento contra hegemônico do setor privado. Para ele "essa redução trouxe diversas implicações para o setor, como por exemplo, a instalação de instituições públicas em áreas geográficas de menor interesse para a rede privada” (p. 3). Em termos quantitativos, o autor destacou que no "período 1985-1996, ocorreu a diminuição do número de instituições privadas isoladas, de 732 para 643” (p. 3). Isso ocorreu conjuntamente com um debate acerca da qualidade de acesso a esse nível de ensino "apontando para a desaceleração do setor superior privado, com sérias críticas à qualidade de grande parte de suas propostas" (SOUSA, 2013, p. 28)

A partir desse cenário, tanto FHC quanto Lula criaram políticas de avaliação da educação superior com o propósito de melhorar e regular a oferta de cursos e de instituições do setor público e privado. No governo do primeiro implementou-se o Exame Nacional de 
Cursos (ENC), popularmente conhecido como "Provão"35", e no do segundo o Sistema Nacional de Avaliação da Educação Superior - Sinaes. Com isso, esses presidentes, mesmo instituindo perfis diferentes de avaliações, criaram espaços para que a avaliação dos cursos de nível superior passasse a ser prática definida no âmbito das políticas públicas educacionais, conforme já previa a Constituição Federal e, posteriormente, a LDBEN/1996.

Conforme destacou Sampaio (2000), a Constituição Federal de 1988 colaborou, de forma definitiva, para impulsionar o setor privado no que diz respeito à oferta de educação, ao prever em seu art. 209, incisos I e II que "o ensino é livre à iniciativa privada atendidas as seguintes condições: cumprimento das normas gerais da educação nacional e autorização e avaliação de qualidade pelo poder público" (BRASIL, 1988). Destaca-se aí, o trecho que fala sobre a aferição da qualidade. Nesse sentido, as políticas de avaliação, apesar das críticas, passam a ocupar um espaço cada vez maior na agenda do governo. Mesmo com deficiências, sua implementação é importante para imprimir uma cultura avaliativa à qual todas as demais políticas do setor seriam submetidas. Como exemplo, cita-se o ProUni e sua vinculação à avaliação dos cursos empreendia pelo Sinaes. Segundo a gestora (GM2),

[...] um curso para ter acesso ao ProUni [...] ele tem que ser um curso bem avaliado porque o que se pretende é a garantia de que este estudante que tá tendo acesso a financiamento, ele acesse um curso de boa qualidade. Então, você hoje considera que pra que esses cursos possam acessar o Fies ou o ProUni ele têm que ter um bom resultado na avaliação. É a garantia dessa qualidade. [...] o ProUni, por sua vez também fica impactado pela avaliação porque sua permanência no sistema de ensino depende do resultado da avaliação.

Considerando essa fala, reitera-se a importância de uma política avaliativa como garantia de qualidade na oferta dos cursos e instituições. No entanto, apesar do esforço do governo, sabe-se que ainda há muito a percorrer para que o cenário da educação superior brasileira alcance excelência.

A partir da análise do texto constitucional de 1988, Leher e Barreto (2008) afirmam que apesar da universidade ser tratada com exclusividade pela Carta Magna, no seu art. 207,

\footnotetext{
${ }^{35}$ O Exame Nacional de Cursos foi instituído pela Lei $\mathrm{n}^{\circ}$ 9.131, de 24 de novembro de 1995 em que dizia que o MEC realizaria "avaliações periódicas das instituições e dos cursos de ensino superior, fazendo uso de procedimentos e critérios abrangentes, dos diversos fatores que determinam a qualidade e a eficiência das atividade de ensino, pesquisa e extensão" (CUNHA, 2003, p. 49). Segundo o autor, o exame, conhecido como Provão, sofreu fortes críticas por ter sido considerado um exame em que se privilegiou a dimensão individual em detrimento da institucional. Já o Sinaes instituído pela Lei $\mathrm{n}^{\circ} 10.861$, de 14 de abril de 2004 foi a política de avaliação da educação superior, do governo Lula, que substituiu o ENC e a avaliação das condições de oferta dos cursos de graduação de FHC. Segundo Ferreira (2012), dentre as críticas sofridas pelo Sinaes, estava a de "conter uma lógica produtivista e meritocrática, em que o Estado prioriza o seu papel de avaliador e regulador". (p.462)
} 
foram as outras formas institucionais que sobressaíram na oferta dos cursos de graduação. A universidade foi definida a partir da indissociabilidade entre ensino, pesquisa e extensão e da prerrogativa de usufruir de autonomia didático-científica, administrativa e de gestão financeira, reservada apenas a esse tipo de instituição. No entanto, os autores chamaram a atenção para o número exponencialmente maior, dos outros modelos previstos, pertencentes ao setor privado.

No ano em que foi promulgada a Constituição, havia 871 instituições de ensino superior, sendo 87 universitárias, das quais 31 eram privadas. Já em 2006, as instituições públicas eram representadas por 248 unidades e as privadas, por 2.022. (LEHER; BARRETO, 2008). Esse crescimento substancial da iniciativa privada provocou uma mudança em relação ao papel da educação superior e despertou o debate acerca da presença empresarial no setor. Considerando que as instituições privadas são divididas em: com ou sem fins lucrativos, chama atenção o fato de as particulares (com fins lucrativos) possuírem 55\% das matrículas desse setor, no ano relatado pelos autores.

Diante desse cenário, Leher e Barreto (2008) chamaram a atenção para o reduzido número de estudantes que frequentam um ambiente de pesquisa, tendo em vista que essa só é exigida, constitucionalmente, em espaço universitário. Os autores criticaram o modelo dos centros universitários, criados em $2006^{36}$, por não ser obrigatória a realização de pesquisa em seus campi, a despeito do nome. Destacaram a proliferação de instituições isoladas, integradas, faculdades tecnológicas, além das particulares stricto sensu.

Resgatando os "ecos" da Reforma Universitária de 1968, conforme termo utilizado por Vieira (2008), Mancebo (2015), destacou que aquela legislação "proibia que as instituições de ensino dessem lucro, mas as instituições particulares os praticavam" (p. 147). No entanto, a autora chama a atenção para o texto constitucional de 1988, que tornou explícita essa possibilidade, sendo, posteriormente, regulamentada, pela LDBEN/1996, que contribuiu, segundo ela, para o crescimento do setor privado.

\footnotetext{
${ }^{36}$ Os centros universitários foram instituídos com base no art. 45 da LDBEN que diz: "A educação superior será ministrada em instituições de ensino superior, públicas ou privadas, com variados graus de abrangência ou especialização" (BRASIL, 1996). Em 1997 esse modelo institucional foi previsto no Decreto 2.207, em seu art. $4^{\circ}$. Tal norma foi revogada em agosto do mesmo ano, pelo Decreto ${ }^{\circ} 2.306$, de 19 de agosto. Portanto, como será visto adiante, vários diplomas legais trataram dessa modalidade de IES. Nesse sentido, quando os autores citaram o ano de 2006 para tratar de sua criação, eles se referiram ao Decreto n ${ }^{\circ} 5.773$ de 09 de maio de 2006, que dispunha "sobre o exercício das funções de regulação, supervisão e avaliação de instituições de educação superior e cursos superiores de graduação e sequenciais no sistema federal de ensino" e que, em seu art. 12 tratava do credenciamento das IES, de acordo com sua organização e prerrogativas acadêmicas. O referido artigo previu três tipos de instituições: faculdades, centros universitários e universidades. (BRASIL, 2006)
} 
Pelo fato de o Prouni ser uma política que tem o setor privado como protagonista, fez-se necessário analisar a conjuntura educacional à luz da expansão das instituições privadas no país com o objetivo de contextualizar o cenário em que surgiu o Programa. Considerando, no entanto, que nenhuma ação do governo é implementada sem um ambiente que favoreça e estimule sua formulação, foi necessário entender as dimensões histórica, política e social que resultaram na política abordada nesta pesquisa, o que faz toda a diferença para a compreensão dos objetivos e resultados dessa.

A par desse raciocínio, em seguida foi analisada a política de educação superior no governo FHC a partir de seu modelo de Estado. Essa perspectiva fez-se necessária para que fosse possível compreender a lógica privatista na qual se pautou a expansão da oferta de graduação em seu governo. Na sequência, o modelo expansionista desse nível educacional, no governo Lula, foi o ponto de partida para analisar a política, foco deste trabalho. O ProUni, ao contar com as instituições privadas como principais parceiras na oferta de vagas de graduação, se impõe como uma política que desnuda as contradições estabelecidas na relação entre o público (governo) e o privado (IES).

Portanto, é mister destacar o caminho percorrido pela história da educação superior brasileira até os dias atuais, em que o setor privado contou com o estímulo do governo e do mercado para sua expansão. Na contramão, ficaram as instituições públicas, que mantiveram seu caráter elitista, ao não contarem com o apoio do Estado para se expandirem, realidade que inviabilizou o protagonismo delas no processo de democratização do acesso à educação superior no país. Ao analisar o ProUni sob a perspectiva da privatização da educação superior, Sousa (2010) questionou se

[...] o referido Programa configura-se como instrumento de democratização da educação superior ou, se em outra direção, não é uma simples ação de estímulo à expansão das IES privadas, reiterando uma tendência histórica na educação brasileira de restrição ao público e estímulo à expansão do privado. (p. 13).

Não há dúvidas de que o Estado brasileiro fez clara opção pelo setor privado ao permitir a proliferação de instituições nesse âmbito sem, no entanto, lançar uma ofensiva capaz de restringir essa expansão desmedida. É certo que as universidades públicas são fundamentais para o desenvolvimento da ciência, da tecnologia e, sobretudo, da pesquisa, em todas as áreas do conhecimento. Não há dúvidas de que essas instituições ocupam lugar de destaque na formação do indivíduo, sob a perspectiva da emancipação humana. A opção do estado pela oferta privada depõe contra essa possibilidade. No entanto, no momento em que o 
sistema é representado por quase $80 \%$ das matrículas no setor privado, medidas devem ser tomadas para que a população não fique refém do mercado. Além disso, políticas como o ProUni, em que pese as críticas, deve fazer parte de uma política mais abrangente de democratização do acesso à educação superior, com promoção da justiça social, pois, de fato, não há, no contexto atual, como prescindir das IES privadas para o acerto com a história.

\subsection{A expansão da educação superior nos dois mandatos do governo de Fernando Henrique Cardoso (1995-1998 e 1999-2002)}

Podemos considerar que a morfologia do campo da educação superior no governo Fernando Henrique Cardoso caracterizou-se pela sua configuração de Estado. Isso significa dizer que o modelo gerencialista, proposto por sua reforma do Estado e implementado pelo então ministro da Administração e Reforma do Estado, Luiz Carlos Bresser-Pereira, esteve presente também em sua concepção de educação superior.

Para Bresser-Pereira (2008), a reforma gerencialista "foi uma resposta ao tamanho do Estado, que implicou sua transformação em um Estado Social”. A intenção foi superar o modelo burocrático a partir do gerencial, caracterizado pela busca por resultados e por maior participação do setor privado na oferta de serviços. A oferta pela educação superior passou a ser considerada um serviço e não uma obrigação do Estado. Segundo o autor, a necessidade em fazer uma reforma que alterasse o perfil das atividades estatais se deu por três motivos: crise política, crise fiscal e crise administrativa. Bresser-Pereira (1996) afirmou que o modelo de Estado social e econômico do século XX havia se tornado ineficiente. A partir dessa constatação, o mentor da reforma gerencialista na década de 1990 explica que

[...] a modernização ou o aumento da eficiência da administração pública será o resultado a médio prazo de um complexo projeto de reforma, através do qual se buscará a um só tempo fortalecer a administração pública direta ou o "núcleo estratégico do Estado", e descentralizar a administração pública através da implantação de "agências autônomas" e de "organizações sociais" controladas por contratos de gestão (p. 18).

Partindo dessa proposta de reforma do Estado, o referido ministro reservou à educação superior o status considerado um dos mais relevantes, a saber: de serviço nãoexclusivo, em que as universidades seriam propriedades públicas, mas não estatais, ou seja, seriam geridas pelo direito privado. Para Bresser-Pereira (1996), “ela é pública do ponto de 
vista dos seus objetivos, mas privada sob o ângulo jurídico" (p. 21). Detalhando melhor sua proposta, o autor diz que

[...] no setor dos serviços não-exclusivos de Estado, a propriedade deverá ser em princípio pública não-estatal [...]. O fato de ser pública não-estatal, por sua vez, implicará na necessidade da atividade ser controlada de forma mista pelo mercado e pelo Estado. O controle do Estado, entretanto, será necessariamente antecedido e complementado pelo controle social direto, derivado do poder dos conselhos de administração constituídos pela sociedade. E o controle do mercado se materializará na cobrança de serviços (p.22).

A reforma do Estado idealizada e, em parte, implementada pelo governo de FHC, nada mais foi do que a tentativa de atender aos ditames dos organismos internacionais em relação à reconfiguração do estado à luz das concepções neoliberais definidas para os países em desenvolvimento. Pode-se citar o Consenso de Washington ${ }^{37}$ como um dos principais eventos que definiram as diretrizes a serem seguidas para a superação da crise do capital, instalada nos países que atendem às regras da economia globalizada.

Em nome da estabilidade econômica e do saneamento das contas públicas, FHC impôs uma política de contenção de gastos que atingiu, principalmente, as políticas sociais, escolhidas como vilãs do desequilíbrio financeiro do Estado. Seguindo esse raciocínio, a reforma do estado empreendida por Bresser-Pereira pretendia reduzir a ação do governo no campo social, deixando a cargo do setor privado essa função em áreas como educação superior, por exemplo, considerada em seus termos, como serviço não-exclusivo do Estado.

Para elaborar seu plano de reforma estatal, o governo de FHC pautou sua linha de ação a partir da lógica de Estado neoliberal. Para compreender o que isso significa, vale citar o conceito de neoliberalismo utilizado por Bianchetti (1997). Segundo ele,

[...] a característica mais importante do neoliberalismo é a ampliação do raio de ação da lógica de mercado. Enquanto nas concessões liberais-sociais se reconhece a desigualdade derivada do modo de produção capitalista e, portanto, aceita-se a intervenção do estado para diminuir polarizações, o neoliberalismo rechaça qualquer ação estatal que vá além da de ser "um árbitro imparcial" das disputas. A ideia do Estado Mínimo é uma

\footnotetext{
${ }^{37}$ Reunião entre banqueiros, políticos, empresários, representantes de organismos internacionais e intelectuais, com o objetivo de discutirem um documento com programa de estabilização e reforma econômica a ser aplicado tanto em países centrais, como em desenvolvimento (LIMA, 2007). Esse evento foi a concretização de uma ideologia em que os "neoconservadores propugnaram um Estado capaz de proporcionar a segurança para o mercado livre e ao mesmo tempo, capaz de, nas crises, frear os descontroles e, nos momentos estáveis, induzir mudanças nas relações com as instituições sociais e jurídicas dos países (SILVA, 2013, p. 61).
} 
consequência da utilização da lógica do mercado em todas as relações sociais não reduzidas somente ao aspecto econômico (p. 88)

A concepção de redução do tamanho do Estado foi, de fato, levada a cabo, com a privatização de grandes empresas nacionais, na tentativa de reduzir drasticamente sua ação em determinadas áreas, não só no campo econômico como e, principalmente, no raio das políticas sociais. Essa perspectiva contraria o que Marx (2007) pensava acerca do papel do Estado e de sua relação com o indivíduo. Para ele, "o estado é o intermediário entre o homem e a liberdade humana $[. .$.$] constitui o intermediário ao qual o homem confia toda a sua não$ divindade, toda a sua liberdade humana" (p. 11). Depreende-se daí, que o estado não pode ser um simples juiz que regula as ações do livre mercado, deixando o indivíduo a mercê da própria sorte. O Estado tem a obrigação de agir junto às assimetrias da sociedade, sobretudo com políticas sociais que reduzam as desigualdades, típicas de países em desenvolvimento. A liberdade do indivíduo, citada por Marx, é confiada ao Estado. Portanto, esse não pode sucumbir aos ditames dos organismos internacionais que padronizam, sob a égide do grande capital, as políticas econômicas. Num claro movimento etnocêntrico, em que a cultura e as particularidades de cada sociedade são desprezadas, esse fenômeno foi promovido em nome dos interesses de uma economia global.

A educação, como política social, sofreu as consequências da reconfiguração do Estado a partir da lógica dos organismos internacionais e das concepções neoliberais sobressalentes. Para Vale, Chaves e Carvalho (2015),

[...] o projeto neoliberal de educação dos organismos internacionais é para os países periféricos do capital caracterizado pelo aprofundamento da privatização, pela desnacionalização da educação e consolidação de um novo mercado educativo global. Tal projeto vem sendo materializado na América Latina, imposto por meio de "acordos comerciais" estabelecidos entre esses organismos e os governos, com a finalidade de submeter a educação às exigências da lucratividade do capital (p. 72).

O modelo de expansão da educação superior de FHC foi visto como resultado desse projeto neoliberal. Com a multiplicação de instituições privadas e a estagnação do setor público, evidenciou-se a priorização da iniciativa privada em detrimento do investimento nas instituições públicas. Diante dessa realidade, o que se verificou foi a assunção do Estado a um papel regulador em substituição à sua função de prover e intervir junto às iniquidades sociais típicas de um país onde ainda prevalecem profundas desigualdades com grande impacto na escolarização das pessoas. Por isso, programas que objetivem reduzir os entraves que 
aprofundam essas assimetrias eram fundamentais para a construção de uma sociedade mais justa. Nesse sentido, sucumbir à lógica internacional para elaboração de políticas a serem implementadas na realidade local faz parte de um contexto que reafirma a herança histórica de alijamento econômico e educacional de determinados grupos sociais no Brasil. Sendo assim, a formulação de programas e ações que superem as perdas desses estratos faz-se mais que necessária e urgente.

O ProUni, criado em 2004, apresentou-se como uma proposta de redução dessas desigualdades, ao propor ações que visassem democratizar o acesso à educação superior, com critérios de renda e com políticas afirmativas que alcançassem grupos étnico-raciais e pessoas com deficiência. No entanto, esse Programa contou com o setor privado como principal parceiro do Estado. Nesse sentido, pode-se dizer que a referida política fortaleceu ainda mais um setor que, com alguns períodos de retração, se consolidou a partir da década de 1960 e voltou com força nos anos de 1990.

No governo FHC, o setor privado encontrou terra fértil e transformou-se no primeiro grande movimento para a democratização do acesso à educação superior. No entanto, na esteira da expansão educacional privada não houve uma política que focalizasse grupos historicamente desassistidos. O que se viu foi a ampliação da rede privada, que, de alguma forma, criou condições de concorrência com mais opções de cursos e de instituições.

Para explicar a importância que esse setor assumiu na oferta desse nível de educação no governo de Fernando Henrique Cardoso, Sousa (2013) afirmou que

[...] a expansão privatista das vagas e a mercantilização do sistema foram alguns dos traços mais marcantes da educação superior brasileira, na década de 1990. Essas características fundamentais ajudaram a delimitar o perfil desta atividade no meio social e contribuíram para determinar um caminho mais voltado, provavelmente, para o atendimento a demandas do mercado de trabalho e aos interesses econômicos (p. 36)

Em consonância com a análise feita a partir da teoria do capital humano, já citada, Sousa (2013) ratificou a tendência desse modelo de educação utilitarista, prevista pela expansão privatista da era FHC. Tal análise confirmou o entendimento de que esse modelo de educação superior, explicada à luz da ideologia neoliberal, foi fortalecida, a partir da década de 1990, como consequência da crise econômica da década anterior.

A concepção de Estado nesse governo impactou fortemente a política de educação superior daquele momento. Ao optar por não investir no setor público, o governo FHC escolheu expandir sem gastar, incentivando iniciativas, no âmbito das universidades públicas, 
de autofinanciamento, com a criação de fundações de direito privado, por exemplo. Além disso, imprimiu um modelo de expansão via setor privado, que aprofundou a polêmica em torno do perfil mercadológico assumido por sua política educacional.

Ao explicar as formas de privatização que pode ser empreendida pelo Estado como opção de transferir ao mercado responsabilidades anteriormente assumidas pelo governo, Leher (2003) destacou como se deu esse processo, no âmbito das universidades no governo de FHC. Conforme o autor, na

[...] área educacional, a criação de condições legais para o livre fornecimento privado e para o direcionamento das instituições públicas para a esfera privada, por meio das fundações privadas, contratos, convênios com o setor empresarial, é tão ou mais importante do que a venda da participação estatal de um determinado setor (p. 8).

Percebe-se, no entanto, que a trajetória traçada pelas determinações liberais deram ao governo a justificativa para ampliar o papel do mercado, incluindo aí o segmento da educação superior pública. Na outra ponta e com mais liberdade, deu-se o movimento de expansão desenfreada da esfera privada. Não por acaso, o número de IES desse setor cresceu exponencialmente nesse período.

Ao analisar esse modelo empreendido por FHC, Minto (2006) afirmou fazer parte de "uma política integrada, um projeto de mundo e de homem e, portanto, de universidade e ensino superior - consubstanciado nos conhecidos termos da ideologia neoliberal e da pósmodernidade" (p. 246-247). Portanto, não se pode considerar que a opção daquele governo pela diversificação institucional, diversidade de cursos e flexibilidade curricular foi descolada de uma política consciente, pautada pelas orientações dos organismos multilaterais, os quais dão centralidade ao papel do mercado em detrimento da atuação do Estado. Esse caminho foi definido a partir do modelo de Estado e, consequentemente, de educação, que o governo quis implantar no país. Para exemplificar, segue trecho do programa de governo de FHC para seu segundo mandato, em que descreve algumas características que atendem aos ditames neoliberais para a educação e sua lógica ao fornecimento de mão de obra qualificada ao mercado de trabalho.

A ampliação e diversificação das oportunidades educacionais no nível superior não podem tardar. É indispensável implementar novas estruturas curriculares, flexíveis, aptas a se conectar com as mudanças em curso na sociedade e que garantam um efetivo dinamismo ao aprendizado. 
Cursos pós-médio, isto é, formação de nível superior de menor duração, assim como a introdução de cursos sequenciais e modulados, com certificação intermediária, a exemplo do que é costumeiro em outros países, permitirão uma expansão substancial da oferta, a um custo adicional razoável, e poderão atender a demandas específicas de um mercado de trabalho em permanente mutação.

É necessário diversificar o sistema, tanto em relação aos programas de ensino oferecidos como em relação à natureza das instituições que $o$ integram. O novo sistema continuará tendo nas universidades de pesquisa suas instituições centrais, geradoras de conhecimento e promotoras de ensino de alto padrão. Mas comportará também instituições diferenciadas, para o atendimento das necessidades de formação de recursos humanos, tanto nas áreas tradicionais do ensino superior, como nas áreas que emergem da nova configuração do mercado de trabalho. (PSDB, 2010, p. 65).

Esse trecho do programa de governo de FHC não deixou dúvidas quanto à opção baseada numa visão de Estado que foi feita para realizar a expansão do acesso à educação superior no país. À luz da ideologia neoliberal, o ministro da educação de FHC, Paulo Renato de Souza, gestor dessa área durante os oito anos do referido governo, fortaleceu o setor privado, por meio da ampliação da rede e dos cursos, conforme descrito no programa. A seguir, alguns dados ilustram a evolução do número total de matrículas no setor privado, (independentemente da idade) nos cursos de graduação presencial referente ao primeiro e último ano do governo de Fernando Henrique Cardoso.

Tabela 2 - Taxa de crescimento - matrícula bruta na educação superior por categoria administrativa nos anos de 1995 e 2002

\begin{tabular}{|c|c|c|c|}
\hline Ano & Público & Privado & Total \\
\hline 1995 & $39,8 \%$ & $60,2 \%$ & $100 \%$ \\
\hline 2002 & $30,2 \%$ & 69,85 & $100 \%$ \\
\hline Taxa de crescimento 95/02 & $50,1 \%$ & $129,3 \%$ & $97,7 \%$ \\
\hline Média anual & $6,3 \%$ & $16,1 \%$ & $12,2 \%$ \\
\hline
\end{tabular}

Fonte: Gomes e Moraes (2012). Dados: MEC/Inep. Elaboração própria

Os dados mostram que, enquanto as matrículas do setor público cresceram 50,1\% nos oito anos da era FHC, as das instituições privadas cresceram 129,3\%, o que ratifica a tese de que seu governo contribuiu para a privatização da educação superior no país. Vê-se que a taxa de crescimento anual das matrículas no sistema federal, como um todo, cresceu $12,2 \%$ no mesmo período, enquanto apenas no setor privado cresceu $16,1 \%$ e no público $6,3 \%$. 
Depreende-se daí que no octênio de 1995 a 2002 a proposta de diversificação do sistema foi levada a cabo, com o fortalecimento das instituições privadas.

Sobre o assunto, Cunha (2003) destacou que até 2001, entre os formatos institucionais de educação superior previstos no Decreto n 2.306/97, com exceção dos centros de educação tecnológica, os demais eram majoritariamente privados. As faculdades isoladas representavam $74,47 \%$ do total de instituições nesse período, sendo $92 \%$ privados. Desse grupo, 4,74\% eram centros universitários, sendo 4,6\% na esfera privada. Vale destacar que suas matrículas representavam apenas $1,1 \%$ do total de estudantes nos cursos de graduação. Já as universidades, abarcavam 64,5\% dos discentes. Segundo o autor

[...] foi muito rápido o crescimento das universidades privadas: no primeiro ano do octênio, elas eram 63. As universidades públicas ficaram estacionadas no mesmo período. Mas o dinamismo do setor privado expressou-se, igualmente, na categoria centros universitários, que não existiam em 1995 e já eram 66 em 2001, dos quais apenas dois públicos (p. $55)$.

O papel dos centros universitários despertou algumas controvérsias e críticas acerca de sua configuração. Representantes do setor público questionavam esse modelo ao considerar que a previsão desse tipo de instituição servia apenas ao atendimento dos interesses do setor privado, promovendo seu fortalecimento em detrimento das universidades públicas. Para Cunha (2003), o caráter autônomo, concedido aos centros universitários, confrontava-se com o que se espera de uma universidade em sentido estrito e seu papel junto à sociedade. Segundo o mesmo,

[...] detentores de quase toda a autonomia universitária, os centros universitários ocupam o lugar, no discurso reformista oficial, da universidade de ensino, definida por oposição à universidade de pesquisa, esta sim, a universidade plenamente constituída. (p. 54, grifo do autor)

Como voz discordante dessas críticas, Guimarães e Silva (2005) destacam que a resistência oferecida à criação dos centros universitários deveria vir acompanhada de “alternativas viáveis para suprir o déficit do país em termos de acesso ao ensino superior” (p. 103). Para eles, há uma tendência global por formação desse nível de educação e o Brasil faz parte desse movimento. Portanto, na visão desses autores, questionar a diversificação institucional é ir à contramão da tendência mundial, sobretudo a daqueles países que, ao superarem o modelo de universidade tradicional, atingiram índices invejáveis de escolarização. 
De fato, esse modelo de instituição desperta forte antagonismo entre os sujeitos envolvidos com a educação superior, sejam professores, gestores ou representantes de associações do setor. Sem dúvida, o ponto nevrálgico desse antagonismo está relacionado à previsão de autonomia de que usufruem, nos moldes das universidades públicas, sem a obrigatoriedade do desenvolvimento da pesquisa - atividade que demanda forte investimento. Os defensores desse modelo, no entanto, alegam que a essas instituições estaria prevista a excelência no ensino, acompanhada de política de avaliação, conforme disposto na LDBEN/96 ${ }^{38}$ e no Decreto no 2.207/97 (revogado pelo Decreto n 2.306 de 19 de agosto de 1997).

O marco legal que tratou dos centros universitários foi amplo e marcado por mudanças de rumo em seu percurso. Essa característica revelou certa instabilidade do governo no trato da matéria, tanto no de FHC, quanto no de Lula. Lastreada pelos artigos 207 e 208 da Constituição Federal de 1988, assim como pelos artigos 45 e 54 da LDBEN/96, a criação dos centros universitários foi prevista no Decreto no 2.207, de 15 de abril de 1997, que, em seu artigo $4^{\circ}$ definiu essas IES como

[...] instituições de ensino superior pluricurriculares, abrangendo uma ou mais áreas do conhecimento, que se caracterizam pela excelência do ensino oferecido, comprovada pela qualificação do seu corpo docente e pelas condições de trabalho acadêmico oferecidas à comunidade escolar, nos termos das normas estabelecidas pelo Ministro da Educação e do Desporto para o seu credenciamento. (BRASIL, 1997, art. $4^{\circ}$ ).

Como já foi destacada, a grande controvérsia acerca desse modelo dizia respeito à autonomia que esses centros universitários tinham para "criar, organizar e extinguir, em sua sede, cursos e programas de educação superior, com a ressalva dos cursos de Medicina, Odontologia, Psicologia e Direito" (GUIMARÃES e SILVA, 2005, p.105), conforme definido no referido Decreto. Os referidos autores fizeram um apanhado de toda a legislação que regulou esse tipo de instituição e destacou que no mesmo ano em que foi publicada a autorização para sua criação, foi assinada a Portaria n 639/1997 determinando que essas instituições só poderiam ser criadas a partir da "transformação de faculdades, institutos superiores ou universidades já credenciadas em funcionamento, que demonstrem excelência no campo de ensino" (p. 105). Os autores destacaram então, que estaria proibida a criação de instituições já definidas, na origem, como centros universitários.

\footnotetext{
38 Está explícito no $\S 2^{\circ}$ do art. 54 da LDBEN a previsão de avaliação ao tratar da autonomia nas IES. “Atribuições de autonomia universitária poderão ser estendidas a instituições que comprovem alta qualificação para o ensino ou para a pesquisa, com base em avalição realizada pelo Poder Público". (BRASIL, 1996).
} 
A partir daí, o que se viu foi uma sucessão de normas, caracterizando a instabilidade que marcou o governo ao regular esse tipo de instituição. Foi necessário conciliar interesses diversos, sobretudo das universidades privadas. Essas consideravam injusto que os centros universitários usufruíssem do bônus (autonomia universitária), sem arcarem com o ônus (investimento em pesquisa e extensão) reservado às universidades.

Guimarães e Silva (2005) chamaram de "refluxo" a Portaria no 2.041 de 22 de outubro de 1997, que, dentre outras disposições, estabeleceu em seu artigo $3^{\circ}$ que "os centros universitários deveriam estar acima da média de qualidade de ensino oferecido pelas instituições de ensino superior do país” (p. 106). Segundo eles, o destaque por maior exigência na qualidade dessas IES foi uma reação à insatisfação das universidades. Já, a Portaria $\mathrm{n}^{\mathrm{o}} 2.175 / 1997$, publicada no mesmo ano, previu a abertura de cursos fora de sede por universidades e centros universitários. Para os autores, tal medida serviu de “contemporizador" para o setor, ao atender reivindicações dos dois modelos institucionais.

O que se percebeu na sequência foi um aprimoramento na legislação referente aos centros universitários, pois esse modelo ficou, desde sua criação em 1997, num limbo até se consolidar, após os avanços e recuos normativos que tratou do assunto. No entanto, isso não impediu seu forte crescimento junto ao sistema federal de educação superior. Talvez, por isso a preocupação do governo em normatizar o assunto, pois em alguns momentos foram necessárias medidas que freassem a expansão desmedida desse tipo de IES.

Tomando como ponto de partida a evolução do setor privado, segue gráfico de número 3 que mostra, a partir do primeiro ano do governo FHC, como se deu a evolução das matrículas no setor privado em comparação com o setor público, numa trajetória bianual, até o primeiro ano de governo de Lula, em 2003. 


\section{Gráfico 3: Evolução bianual do número (bruto) de matrículas por categoria administrativa $1995-2003^{39}$ - Brasil}

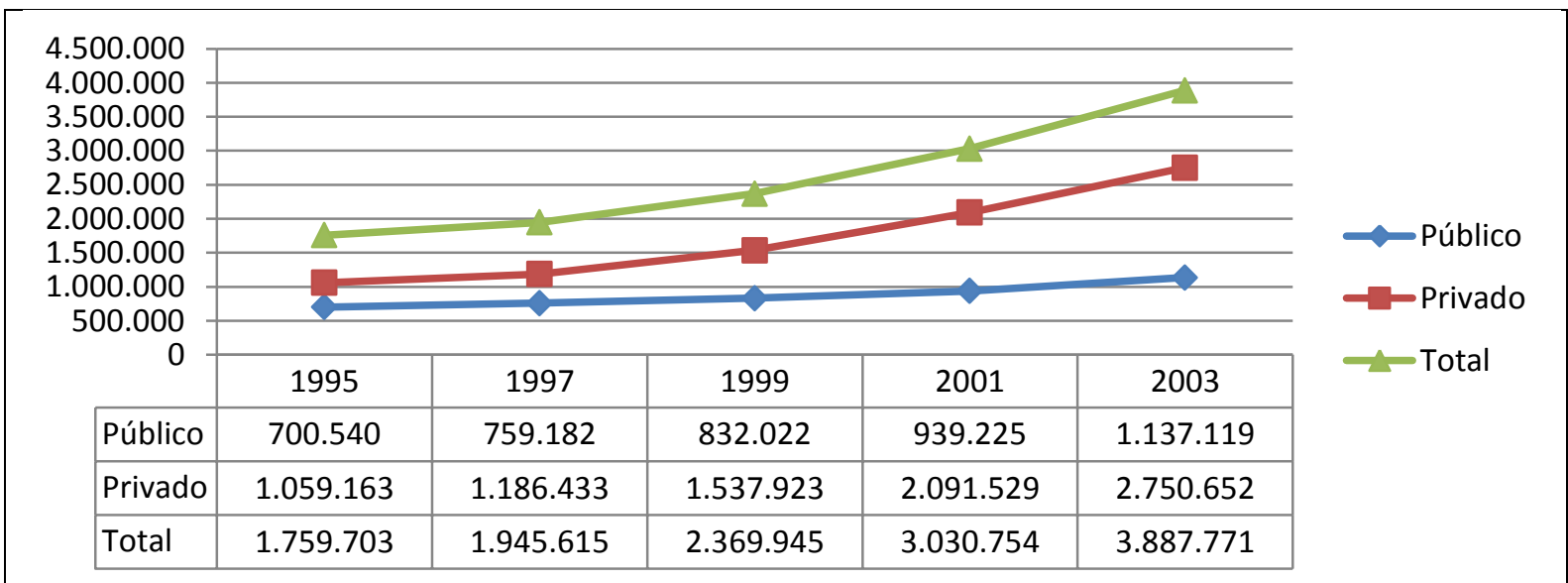

Fonte: INEP/MEC. Dados: Censo da Educação Superior. Elaboração própria.

Vê-se que, ao longo dos mandatos de FHC, as matrículas no setor público cresceram numa proporção bem menor do que as no setor público. Enquanto nesse, em 1995, havia 700.540 estudantes matriculados, em 2003 esse número passou para 1.137.119, representando um aumento de um pouco mais de 436 mil matrículas, o que, em termos percentuais, girou em torno de 40\%. Já no setor privado, houve uma expansão que, em números absolutos, significou 1.691.489 de matrículas. Percentualmente falando, foi uma ampliação de cerca de 160\%. Pode-se supor que, em se tratando do setor público, esse fenômeno deu-se por medidas tomadas no âmbito da própria universidade, considerando que não foram criadas novas instituições nesse período. No entanto, com o incentivo para que as IFES se autofinanciassem, a ampliação de vagas no turno noturno, por exemplo, foi uma das alternativas de seus gestores.

Como o setor privado contou com a "bênção" do governo para sua expansão, fica fácil compreender a forte expansão de suas matrículas, afinal, houve um aumento desmedido de instituições e cursos, nesse período.

A tabela 3, a seguir, apresenta dados comparativos acerca do número de instituições, por categoria administrativa, os quais demonstram a evolução do setor privado, em relação ao público, entre os anos de 1995 a 2003.

\footnotetext{
39 Apesar de o ano de 2003 não integrar o mandato de FHC, optou-se por incluí-lo no gráfico para que fosse possível fechar o ciclo, dividido em períodos de dois anos, abarcando todo seu governo. Vale destacar que o censo da educação superior do referido ano foi finalizado em 30 de junho.
} 
Tabela 3 - Número e percentual de instituições ${ }^{40}$ por dependência administrativa, Brasil 1995 a 2003

\begin{tabular}{|c|c|c|c|c|c|c|}
\hline \multirow{3}{*}{ Ano } & \multicolumn{6}{|c|}{ Dependência administrativa } \\
\hline & \multirow[t]{2}{*}{ Total } & \multicolumn{2}{|l|}{ Pública } & \multirow[t]{2}{*}{$\%$} & \multirow[t]{2}{*}{ Privada } & \multirow[t]{2}{*}{$\%$} \\
\hline & & $\begin{array}{c}\text { Total } \\
\text { Federal/estadual/municipal }\end{array}$ & Federal & & & \\
\hline 1995 & 894 & 210 & 57 & 23,4 & 684 & 76,5 \\
\hline 1996 & 922 & 211 & 57 & 22,8 & 711 & 77,1 \\
\hline 1997 & 900 & 211 & 56 & 23,4 & 689 & 76,6 \\
\hline 1998 & 973 & 209 & 57 & 21,5 & 764 & 78,5 \\
\hline 1999 & 1.097 & 192 & 60 & 17,5 & 905 & 82,4 \\
\hline 2000 & 1.180 & 176 & 61 & 15 & 1.004 & 85,0 \\
\hline 2001 & 1.391 & 183 & 67 & 13,1 & 1.208 & 86,4 \\
\hline 2002 & 1.637 & 195 & 73 & 11,9 & 1.442 & 88 \\
\hline 2003 & 1.859 & 207 & 83 & 11,1 & 1.652 & 88,9 \\
\hline
\end{tabular}

Fonte: INEP/MEC. Dados: Censos da Educação Superior. Elaboração própria.

Percebe-se, nessa tabela, que a configuração do sistema de educação superior seguiu a lógica, iniciada na década de 1960, de oferta majoritariamente privada, de cursos de graduação. Percentualmente, vê-se que enquanto o setor público reduziu sua representatividade no sistema, o privado, inversamente, aumentou. Em 1998 5,9\% das IES eram federais, índice que caiu para 4,5\% em 2003. Já, dentre as privadas, o percentual aumentou de 78,5\% para 88,9\% no mesmo período. Vale destacar que, dentre as privadas há uma distinção entre particulares (com fins lucrativos) e comunitárias, confessionais, filantrópicas (sem fins lucrativos) beneficentes e não beneficentes.

O gráfico a seguir mostra a evolução no número dessas instituições ao longo de todo o governo FHC. Percebeu-se que a linha azul, que representa as IES públicas, manteve-se estável, sem alterações significativas. Já a vermelha, representando as instituições privadas, apresentou considerável inflexão a partir do segundo mandato de FHC, em 1999. O aumento

\footnotetext{
${ }^{40}$ Ressalta-se que no total dessas instituições estão incluídas as universidades, os estabelecimentos isolados, as faculdades integradas e os centros universitários.
} 
mais significativo no número absoluto de IES pode ser verificado na tabela anteriormente apresentada.

Gráfico 4: Evolução do número de instituições de educação superior por categoria administrativa - 1995-2003

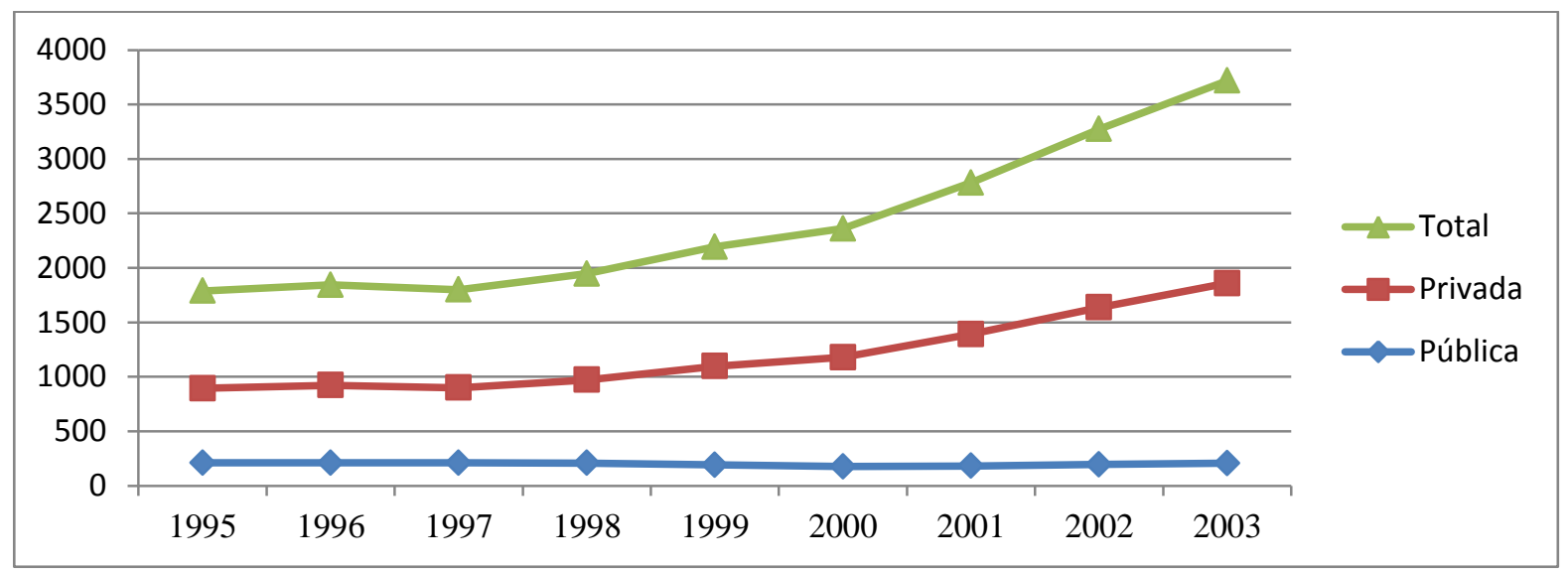

Fonte: INEP/MEC. Dados: Censo da Educação Superior. Elaboração própria.

Fica evidente, pela inflexão da curva representando o setor privado, que a partir de 1999 o aumento passou a ser mais significativo. Isso pode ser explicado pela evolução no número de centros universitários, ocorrida a partir desse ano. Enquanto no ano 1999 contavase com 39 instituições dessa modalidade, em 2003 essas já somavam 81 (GUIMARÃES e SILVA, 2005, p. 99). Em 2005, a quantidade de centros universitários chegou a 114. Esses números evidenciam o alcance que a diversificação institucional, empreendida à luz do marco legal que tratou da matéria, teve para consolidar um novo modelo de expansão do acesso à educação superior.

Outro destaque relevante em relação às configurações das instituições privadas, diz respeito à concepção de entidades lucrativas e sem fins lucrativos. A lei que instituiu o ProUni definiu os critérios para a concessão de bolsas a estudantes carentes, diferenciando o tipo de isenção fiscal que seria concedida a cada modelo. Além disso, a referida legislação dispôs sobre a regulação das entidades beneficentes de assistência social, devido à falta de controle nesse setor.

Ressaltando o modelo diversificado de instituições de educação superior e, consequentemente, privatizante, desse período, vale reiterar o papel que a nova Lei de Diretrizes e Bases da Educação Nacional - LDBEN, Lei n ${ }^{\circ}$ 9.394/96 teve nesse processo. A referida legislação, sobre a qual já se falou anteriormente, confirmou essa lógica privatista ao assegurar mais autonomia às instituições para "criar e extinguir cursos, assim como de 
determinar o número de vagas de cada um, elementos importantes para a sintonia das instituições privadas com o mercado" (CUNHA, 2003, p. 41).

O Conselho Nacional de Educação - CNE, criado no ano de 1995 e que substituiu o Conselho Federal de Educação, instituído pela LDBEN de 1961, foi importante para o processo de privatização da educação superior no país, graças ao jogo político, presente em todo governo de coalizão, sobretudo no regime presidencialista. Seus representantes foram sendo indicados por meio do lobby político. A Câmara de Educação Superior, que compõe o Conselho, juntamente com a Câmara de Educação Básica e o Conselho Pleno, logo passou a ser formada, em sua maioria, por representantes privatistas. Segundo Cunha (2003), "a necessidade de manter uma base parlamentar garantidora dos votos capazes de aprovar os projetos do governo levou o presidente a trocar votos no Congresso por nomeações para postos no Poder Executivo, inclusive no CNE" (p. 48).

Ao referir-se à tendência privatista e à flexibilização institucional, com ênfase nos centros universitários, que desconsidera a integração entre ensino, pesquisa e extensão, Durham (2003) explicou que a LDBEN/96 "reconheceu a heterogeneidade do sistema, no qual coexistem as universidades onde se realizam pesquisas e outros tipos de instituição voltados para o ensino" (p. 225). Ela destacou, portanto, que a nova Lei de Diretrizes e Bases da Educação Nacional

[...] manteve o rígido controle burocrático sobre estas outras instituições. A ampliação da autonomia para outros tipos de estabelecimentos de ensino era desejável para diminuir o centralismo burocrático, se devidamente acompanhada por um sistema de avaliações e recredenciamentos periódicos que coibissem abusos. Decreto presidencial do ano seguinte criou uma nova categoria de estabelecimentos, os centros universitários, dos quais não se exigia pesquisa, mas tão-somente excelência de ensino. A estas instituições se estendeu a autonomia didática para criação de cursos e ampliação de vagas, submetendo-se ao regime de avaliação periódica (p. 225).

Depreende-se dessa citação que a autora concordou com a flexibilização institucional prevista na nova LDBEN, por acreditar que o surgimento de novos modelos de IES e a extensão da autonomia universitária para além das universidades, contribuiria para reduzir a burocracia. Provavelmente, ela se referia à possibilidade de criação de cursos, aumento de vagas e emissão de diplomas, resultantes da referida autonomia, para impactar nas ações burocráticas do Estado, diminuindo seu papel. É compreensível seu posicionamento, considerando que a mesma foi uma das principais figuras que pensaram a educação superior 
no governo FHC. À época, ela ocupou a Secretaria de Política Educacional do Ministério da Educação.

Outra importante característica da política de educação superior implementada por FHC, esteve relacionada à avaliação ${ }^{41}$, como forma de medir a qualidade dos cursos ofertados e das instituições. No entanto, essa iniciativa traduziu-se em regulação do poder do Estado, na promoção da competitividade entre as instituições e do descompromisso com o investimento nesse setor. Dias Sobrinho (2010a) analisou a política de avaliação desse governo como mais uma ação direcionada ao mercado. Para ele, a implementação de avaliação "centrada nos resultados dos estudantes" pressupôs caráter punitivo, hierarquização dos cursos a partir do desempenho do aluno, produção de efeitos econômicos para satisfazer o mercado e ainda estimulou a competição no interior do sistema, entre as instituições. Por fim, "reforça o conceito de educação como mercadoria e induz práticas pedagógicas cujos alvos passam a ser o bom desempenho dos estudantes nos testes." (p. 206).

Nesse sentido, afirma-se que a lógica que pautou a política de educação superior no governo de FHC foi no sentido de atender ao mercado e às demandas econômicas, internas e externas, do país. Ferreira (2012) resumiu seu modelo educacional de nível superior, ressaltando que

[...] as diretrizes políticas passaram pela tentativa da caracterização da educação superior como um serviço público não-estatal; da diminuição significativa do financiamento estatal na manutenção das universidades federais; da mudança do papel do Estado, de financiador para regulador; da privatização; do incentivo de fontes alternativas de financiamento; das parcerias público-privadas; da diferenciação e competitividade entre instituições; da expansão de baixo custo; do ensino a distância; dos sistemas de avaliação; da formação para atender ao mercado de trabalho. Nessa perspectiva, as universidades passaram a ser vistas a partir de uma visão mais pragmática e utilitária dos seus serviços, seja na formação profissional, seja na produção da ciência e da tecnologia, modificando expressivamente os referenciais da sua finalidade e relevância social. (p. 461).

A análise da autora reitera toda a abordagem já feita até aqui, sobre o caráter neoliberal imposto pelo governo, transmutando sua lógica para a oferta de educação superior no país. Ela reforça todas as características fundantes desse modelo de Estado, presentes

\footnotetext{
${ }^{41}$ O Exame Nacional de Cursos sofreu resistência de vários setores da sociedade, tanto dos estudantes, quantos das universidades públicas e privadas. Segundo Sguissardi (2006) "a partir de 1997 passou-se a utilizar um sistema de avaliação da educação superior que comportava [...] dois instrumentos: exame das condições de oferta (infraestrutura, currículo acadêmico, qualificação docente etc.) e o Exame Nacional de Cursos ("Provão")[...]" (p.1031). Sobre o exame, o autor destacou que a imprensa passou a utilizar seus resultados de maneira a colocá-lo sob suspeita de "mais servir ao interesse oficial de demonstrar controle sobre o sistema do que de efetivamente avaliá-lo e regulá-lo". (p. 1032).
} 
também no modelo educacional. Apesar da preocupação em aumentar as vagas nos cursos de graduação para o atingimento de um maior número de pessoas, não houve nesse período, o que se espera de uma política de democratização. Considerando o déficit histórico de nossa sociedade, em relação aos diversos grupos alijados do acesso à educação superior, a opção pela simples ampliação de vagas, sem a preocupação de focalizar determinados estratos da sociedade, não cumpre o papel que se espera de uma política pública. Pelo contrário, ao desprezar a necessidade de lidar, de forma diferente, com uma parcela da população que, ao longo de gerações, foi excluída das políticas públicas, o governo aprofunda as desigualdades sociais e contribui para a manutenção do país numa posição vergonhosa de submissão a interesses alheios às reais necessidades do país.

É mister ressaltar que a taxa de escolarização de nível superior brasileira é muito baixa. E pior fica quando se analisa os dados estratificados por renda, raça, origem escolar e local de moradia, além de outras variáveis. Portanto, implantar políticas que desconsideram as assimetrias econômicas e sociais é incorrer num erro histórico; é insistir na manutenção de uma sociedade desigual, dividida em classes, com profundas diferenças. Ao optar por priorizar a educação fundamental em detrimento da superior, como sugere o Banco Mundial (BM), Fernando Henrique Cardoso desassocia os níveis de educação para a formação do indivíduo e desmonta o "caráter sistêmico" de que a educação deve estar imbuída, conforme destacou MEC (2007), quando do lançamento do Plano de Desenvolvimento da Educação PDE.

Paradoxalmente, ao analisar a política de educação superior de Lula, será possível verificar semelhanças entre seu governo e o de seu antecessor, principalmente no que diz respeito à expansão da oferta de vagas de nível superior via setor privado, sobretudo após o lançamento do ProUni. Mesmo implementando políticas direcionadas ao setor público, foram as instituições privadas que continuaram como protagonistas das matrículas desse nível educacional.

Ao analisar os dois governos, Lima (2007) reforçou que a política educacional de FHC foi uma "anti-reforma", baseada nos preceitos neoliberais, em que a lógica do mercado pautou suas ações e, para a autora, o então presidente Luiz Inácio Lula da Silva, não só seguiu o mesmo rumo, como aprofundou sua lógica. De acordo com sua convicção,

[...] no governo Cardoso o Brasil vivenciou mais uma face da "anti-reforma" universitária, ou da reforma universitária consentida pelo capital. Somado ao crescente empresariamento da educação superior, esse governo ampliou a privatização interna das universidades públicas brasileiras, ambos sob a 
aparência de democratização do acesso à educação. Estes eixos políticos e pedagógicos foram, e continuam sendo, configurados como as estratégias fundamentais da reformulação da educação superior brasileira em curso no Brasil, a ser aprofundada na terceira fase da contra-revolução, sob a condução do governo Lula da Silva. (p. 152).

A opção pelo setor privado para expandir o acesso às instituições de educação superior no governo FHC foi analisada por um gestor do MEC, entrevistado, e considerada importante pelo mesmo, devido a sua abrangência. No entanto, ele ressaltou o perfil neoliberal da política, ao destacar sua tendência em privilegiar esse setor em detrimento da esfera pública. Destacou ainda a intenção do governo em acabar com o modelo de universidade pública, por considerá-lo muito oneroso ao Estado. Segundo ele, a

[...] expansão da educação superior no governo Fernando Henrique foi significativa. Em primeiro lugar, houve um crescimento grande, mas ele se deu basicamente pelo setor privado, então é uma expansão com privatização do sistema. Acho que o grande impulso da privatização se deu nesse período. Agora, tem que admitir que foi uma expansão expressiva então, nesse sentido, eu acho que ela foi positiva. A única coisa que eu acho que ela não foi positiva é porque ela abandonou a expansão do setor público. As universidade federais nesse período passaram por grandes dificuldades [...] não se abria concurso nenhum e havia manifestações explícitas, inclusive do ministro Paulo Renato, de que o modelo das federais era caro demais e que deveria ser levado à extinção. Inclusive corria uma publicação [...] que previa que o modelo federal estaria esgotado em cinco anos. Então, o que eu diria sobre esse período é basicamente isso, foi importante porque expandiu, mas teve esse problema que expandiu exclusivamente pelo setor privado. $\mathrm{O}$ setor público ficou estagnado e no setor privado expandiu para o setor privado e pago, né (GM1 - informação verbal).

A política de expansão e democratização do acesso à educação superior dos governos de Luiz Inácio Lula da Silva e Dilma Vana Rousseff foi analisada nos subtítulos seguintes. A abordagem de suas políticas educacionais foi feita no sentido de rever seus sentidos e significados, a partir dos objetivos a que se propuseram. Com um discurso voltado à redução das desigualdades sociais, seus governos apresentavam disposição retórica para convencer a população de que medidas seriam tomadas para democratizar o acesso à educação superior, com equidade.

Nesse sentido, o ProUni apresentou-se como uma política de equidade, (conceito entendido como justiça social) ao estabelecer critérios de renda, além de definir cotas étnicoracial e reserva de vagas para pessoas com deficiência. No entanto, um olhar mais aguçado identificou que o caráter e os resultados imediatos das políticas para o setor, em muito se aproximaram das empreendidas pelo presidente Fernando Henrique Cardoso, sobretudo no 
que diz respeito à relação público-privada estabelecida no âmbito da formulação de políticas públicas, em geral, e de educação superior, em particular. Segundo Lima (2007), FHC teve sua lógica privatista seguida pelos governos que o sucedeu.

\subsection{Políticas de democratização do acesso à educação superior no governo de Luiz Inácio} Lula da Silva (2003-2006 e 2007-2010)

O Presidente Luiz Inácio Lula da Silva foi eleito com o discurso da mudança, sobretudo no que dizia respeito às mazelas sociais. Seu governo pretendia reduzir a desigualdade social, acabar com a miséria e melhorar os índices educacionais, dentre outros avanços socioeconômicos. Pode-se dizer que ele conseguiu, em parte, alguns de seus objetivos. Para enfrentar o problema de acesso, por meio da ampliação e democratização da educação superior, Lula lançou mão de algumas políticas cujo objetivo foi avançar nesse setor, por meio dos segmentos público e privado. Em seu plano de governo de 2002 ele ressaltou a necessidade de expandir as vagas nas universidades públicas e de incrementar a política de crédito educativo. A partir de um breve diagnóstico, assim previu o plano:

\footnotetext{
Os dados do Censo da Educação Superior de 2000 mostram que os jovens das camadas mais pobres praticamente não têm acesso à educação superior pública: apenas 7,7\% dos jovens entre 18 e 22 anos freqüentam cursos universitários. Cerca de $70 \%$ deles estudam em estabelecimentos privados. Quando conseguem chegar ao ensino superior, o custo é tão alto que apenas os que têm bons empregos ou apoio econômico da família conseguem pagar a faculdade. Por isso, há elevada inadimplência e evasão, até porque o sistema de crédito educativo, que poderia ser uma alternativa, é insuficiente e inadequado. São tarefas inadiáveis a ampliação significativa das vagas nas universidades públicas e a reformulação do sistema de crédito educativo vigente. (PT, 2002)
}

Como se vê, inicialmente o que estava previsto no documento era promover a expansão de vagas nas universidades públicas e reformular a política de financiamento do setor privado, via crédito educativo. No entanto, em relação às instituições privadas, o que acabou se destacando foi a política de bolsas integrais e parciais do Programa Universidade para Todos, criado em 2004.

Como já foi destacado neste trabalho, toda política pública tem base no modelo de Estado empreendido pelo governo. Tal afirmação serve para explicar a opção que Lula fez, ao apresentar um projeto de lei propondo reformar a política educacional de nível superior. A questão girou em torno do perfil que teria essa ação. Em linhas gerais, era preciso saber se o 
governo continuaria com o modelo privatista de seu antecessor ou se romperia com ele, propondo ações que resgatassem a importância do setor público, nessa área.

É importante ressaltar que houve certo temor da sociedade e, sobretudo, do mercado em relação à vitória de Lula nas eleições presidenciais. O mercado não confiava muito em um possível governo petista, cujo líder teve origem nos movimentos sindicais, ocasionando certa resistência de parcela da sociedade, sobretudo, da classe média, em votar no então candidato. No entanto, isso mudou com a divulgação da "Carta ao povo brasileiro ${ }^{42 "}$ ". Tal documento transmitiu credibilidade e confiança à parcela mais conservadora da população e ao próprio mercado, sobretudo ao ceticismo das agências multilaterais. (SILVA JR.; SGUISSARDI, 2005).

Para abordar a proposta de reforma da educação superior no governo do presidente Luiz Inácio Lula da Silva, Silva Júnior e Sguissardi (2005) fez uma ampla análise conjuntural do contexto político, econômico e social do período, pré e pós eleição, que alçou o ex metalúrgico ao cargo mais alto da República. Interessou aqui destacar apenas as questões relativas à educação superior e às polêmicas que envolveram o debate em torno das esferas pública e privada. Sobre o assunto, os autores descreveram

[...] alguns elementos históricos, conceituais e de princípios, para um exame preliminar do anteprojeto de lei da educação superior, [...] de 2004, como decorrência do processo de transformação da educação superior no Brasil. Esse processo tem se caracterizado por duplo movimento de alternância na valorização das esferas pública e privada, dando-se ora a restrição de uma e a expansão de outras, ora vice-versa, mas mantendo-se com continuidade o crescente caráter mercantil das instituições de educação superior, com graves consequências para sua autonomia e seu financiamento, assim como para a organização do Sistema Federal da Educação Superior; enfim, para sua identidade institucional (p. 6).

Em uma análise comparativa entre os governos FHC e Lula e o quanto houve de continuidade e ruptura no modelo educacional implantado pelos dois presidentes, pode-se considerar que houve mais semelhanças que diferenças, sobretudo no que diz respeito ao protagonismo do setor privado na oferta de educação superior. Apesar das críticas ao seu antecessor, Lula também manteve o mercado como ator importante do seu governo, seguindo

\footnotetext{
${ }^{42}$ Documento de 2002, contendo orientações político-sociais, traduzidas em dez compromissos básicos do futuro governo Lula, rompendo com o pensamento petista tradicional. Para tranquilizar o mercado e a sociedade, vale citar dois pontos da carta, que merecem destaque: i) governabilidade via coalização nacional, que implica processos exaustivos de negociação, alianças, pacto social e crescimento da estabilidade; ii) respeito aos contratos e obrigações do país, não ao calote na dívida externa e política austera de controle do endividamento público. (SILVA JÚNIOR; SGUISSARDI, 2005).
} 
o ideário neoliberal deixada por Fernando Henrique Cardoso. Sobre o assunto, Silva Júnior e Sguissard (2005) explicou que

[...] as políticas recentes especialmente de educação superior, e na reflexão exigida pela materialidade histórica que envolve tanto a contradição público/privado quanto a dimensão central e mercantil do Estado moderno, que se pode compreender melhor a racionalidade político-administrativa do governo FHC e dos dois primeiros anos do governo Lula (p. 17).

Diante da análise conjuntural dos governos FHC e Lula, evidenciou-se que o protagonismo do setor privado manteve-se forte nos dois governos. No entanto, não há como negar que o governo de Lula também implementou políticas importantes voltadas ao setor público, como a Política de expansão das universidades federais - Expandir ${ }^{43}$, em 2006, e o Programa de Apoio ao Plano de Reestruturação e Expansão das Universidades Federais Reuni, em 2007. Nesse sentido, é fato afirmar que a política educacional de Lula foi mais ampla e diversificada que a de FHC, pois, assim como o setor privado contou com o Programa Universidade para Todos - ProUni para o fortalecimento das instituições privadas, o setor público, no que tange às universidades, contou com o Reuni, apesar das críticas que envolveram o Programa.

Para Silva Júnior e Sguissard (2005), a partir dessa relação público-privado e o impacto na educação superior, "a universidade deve organizar-se e manter sua dinâmica interna e suas relações com a sociedade e com o Estado voltadas para o pólo público, restringindo ao máximo o espaço do pólo antiético, o privado" (p. 18). No entanto, alguns especialistas consideram que as instituições privadas de educação superior são atores importantes no processo de expansão do acesso a esse nível de educação. Compartilham, portanto, do raciocínio dos organismos internacionais, assimilados pelo governo neoliberal de FHC, de que a diversificação institucional é necessária, pois nem todo estudante precisaria ter acesso a instituições cujo tripé ensino, pesquisa e extensão estejam presentes, embora, de acordo com o censo da educação superior de 2014, 43\% das universidades são privadas (INEP, 2016). Significa dizer que, segundo esse raciocínio, faculdades, institutos e centros universitários compõem um grupo importante de instituições para o atendimento à demanda por educação superior.

\footnotetext{
${ }^{43}$ O Expandir - Programa de expansão da educação superior pública (2003-2006) foi um programa que objetivou expandir e interiorizar as universidades federais, pelo fato de elas estarem concentradas, sobretudo, nas capitais (DUARTE, 2015). De acordo com a autora, "esse incentivo veio por meio de dotação orçamentária para criação de novas universidades federais e de campi, principalmente, no interior do país". (p. 124).
} 
Essa relação público-privada se desenhou no governo Lula de forma bastante consistente e promoveu ações concretas para sua consolidação. Mancebo (2015) fez uma crítica a essa parceria, ao elencar diversas medidas dessa gestão que atrelaram a produção científica ao setor produtivo. Para o conhecimento dessas medidas, apresenta-se a seguir um quadro com o arcabouço legal sobre o assunto destacado pela autora.

\section{Quadro 1 - Legislações que tratam da relação entre ciência e setor produtivo entre 1994 e 2012}

\begin{tabular}{|c|c|}
\hline $\begin{array}{l}\text { Lei } n^{\circ} 8.958 \text { de } 20 \text { de dezembro de } \\
1994^{44}\end{array}$ & $\begin{array}{l}\text { "dispõe sobre as relações entre instituições federais de } \\
\text { educação superior e de pesquisa científica e tecnológica e as } \\
\text { fundações apoio"; }\end{array}$ \\
\hline $\begin{array}{l}\text { Lei } n^{\circ} 10.973 \text { de } 02 \text { de dezembro de } \\
2004 \text { - Lei de inovação tecnológica }\end{array}$ & $\begin{array}{l}\text { "estabelece medidas de incentivo à inovação e à pesquisa } \\
\text { científica e tecnológica no ambiente produtivo, com vistas à } \\
\text { capacitação e ao alcance da autonomia tecnológica e ao } \\
\text { desenvolvimento industrial do país"; }\end{array}$ \\
\hline $\begin{array}{l}\text { Lei } \mathrm{n}^{\circ} 11.079 \text { de } 30 \text { de dezembro de } \\
2004 \text { - Lei das Parcerias Público- } \\
\text { Privadas }\end{array}$ & $\begin{array}{l}\text { "institui normas gerais para licitação e contratação de } \\
\text { parceria público-privada no âmbito da administração } \\
\text { pública"; }\end{array}$ \\
\hline $\begin{array}{l}\text { Lei } n^{\circ} 11.196 \text {, de } 21 \text { de novembro - } \\
\text { Lei do Bem }\end{array}$ & $\begin{array}{l}\text { "consolida incentivos fiscais para pessoas jurídicas, desde } \\
\text { que realizem pesquisas tecnológicas e desenvolvimento de } \\
\text { inovação tecnológica"; }\end{array}$ \\
\hline $\begin{array}{l}\text { V Plano Nacional de Pós-graduação } \\
\text { (V PNPG) }\end{array}$ & $\begin{array}{l}\text { com vigência de } 2005 \text { a } 2010 \text {, "no qual se pôde verificar uma } \\
\text { indução mais forte e definida ao estabelecimento de laços } \\
\text { com as empresas" }\end{array}$ \\
\hline $\begin{array}{l}\text { Portaria Normativa } \mathrm{n}^{\circ} \mathrm{s} 07 \text { e } 17 \mathrm{da} \\
\text { Coordenação de Aperfeiçoamento de } \\
\text { Pessoal de Nível Superior (CAPES) }\end{array}$ & "dispõe sobre o Mestrado Profissional" \\
\hline $\begin{array}{l}\text { VI Plano Nacional de Pós-graduação } \\
\text { (VI PNPG) }\end{array}$ & $\begin{array}{l}\text { com vigência prevista de } 2011 \text { a } 2020 \text {, no qual, segundo a } \\
\text { autora "explicitamente, a produção do conhecimento e a } \\
\text { formação de pesquisadores devem estar comprometidas } \\
\text { "com o aumento do valor agregado de nossos produtos e a } \\
\text { conquista competitiva de novos mercados no mundo } \\
\text { globalizado". }\end{array}$ \\
\hline
\end{tabular}

Fonte: MANCEBO (2015, p. 145)

Esses marcos regulatórios acerca da produção científica vinculando-se ao setor produtivo evidenciaram as singularidades da gestão de Luiz Inácio Lula da Silva alinhadas às proposições previstas pelos organismos internacionais e seu ideário voltado às necessidades

\footnotetext{
${ }^{44}$ Apesar de essa lei ter sido publicada em 1994, no final do governo Itamar Franco, e, portanto, fora do escopo deste trabalho, fez-se relevante tal citação por tratar do assunto abordado pela autora e ter sido por ela citada, além de estar, a referida legislação, ainda vigente.
} 
da economia globalizada. Além disso, reiteraram a disposição em seguir o disposto na Teoria do Capital Humano, já citada neste trabalho, em que as potencialidades educacionais do indivíduo são capitalizadas para o bem de uma sociedade moderna, cuja formação profissional se impõe como pilar fundamental ao seu desenvolvimento.

Uma análise da relação público-privado e de seu funcionamento junto ao Estado moderno, evidenciando suas contradições, foi realizada por Silva Jr. e Sguissardi (2005). Segundo eles, entender o antagonismo que caracteriza essa relação é importante para que seja possível enxergar as opções dos governos e seus impactos na vida de cada cidadão. As políticas públicas são elaboradas a partir da concepção ideológica ou pragmática que cada governo possui. Isso precisa ser compreendido e assimilado pela sociedade de modo que esta seja capaz de pressionar o Estado por mudanças, se assim for entendido como necessário. Para explicar as contradições presentes nessa relação e em que isso influencia no funcionamento do Estado moderno, os autores destacam que

[...] desde logo que o público identifica-se com a sociedade, de um lado, dando origem ao poder político que se materializará no Estado, e, de outro, que o público se torna o pólo antiético do privado no âmbito da sociedade e do Estado. Disso se pode concluir, ainda com Locke, que a natureza institucional do Estado Moderno e do poder político por ele exercido emerge da sociedade e a ela deve submeter-se. Por essa razão, desde a criação do Estado, e particularmente do Estado moderno, existe uma contradição entre o público e o privado em qualquer esfera de atividade humana, especialmente no interior do próprio Estado e de suas instituições, por ação dos atores que neles trabalham. Tal contradição histórica deriva, de um lado, da outorga das atividades de legislar, julgar e executar, que são individuais no estado natural, para a esfera normativa do pacto social (o Estado), e de outro lado, da instituição mesma que sustenta o pacto social por meio do poder político, que é o próprio Estado. Assim, pode-se apontar para um duplo movimento que produziria a indissociável contradição público/privado na sociedade e no Estado moderno. Isso implica afirmar a predominância de um pólo da contradição, o público, ou do seu antiético, o privado, em função de como se organizam a sociedade, o Estado e as relações mediadas pelo poder político, com base na natureza e na economia (p. 14).

Essa abordagem feita por Silva Jr. e Sguissardi (2005) realçou as contradições existentes no interior do governo Lula. Ao destacar as categorias da contradição e da mediação, próprias do materialismo histórico dialético, os referidos autores consideraram sua gestão, como exemplo de uma administração autoritária e centralizadora, em que predominou os valores mercantis. Ressaltaram que as contradições ficam mais evidenciadas 
[...] por um governo que, apresentando-se como popular e democrático, tende a implementar políticas e medidas de reforma que fortalecem contraditoriamente a mercantilização do bem público, sem que este último jamais deixe de existir, ao menos na modernidade (p. 17).

As críticas direcionadas à política educacional de Luiz Inácio Lula da Silva encontraram lastro, sobretudo na decepção de setores da sociedade que esperavam maior ruptura com o modelo implementado pelo seu antecessor. A concretização das expectativas ao novo governo se daria por meio de mais investimento no setor público, entenda-se, nas universidades públicas. $\mathrm{O}$ que se viu, no entanto, foram políticas que deram continuidade à expansão via setor privado. Além disso, as ações previstas no projeto de reforma da educação superior de Lula desconstruíram o modelo de universidade defendida pela classe docente (modelo humboldtiano ${ }^{45}$ ), ao manter a diversificação institucional em atendimento às orientações do Banco Mundial - BM, que considerava esse modelo inviável financeiramente (CHAVES, 2005). Lula consolidou a expansão de vagas, via setor privado, sobretudo após a instituição do ProUni, em 2004.

Ao analisar as orientações do BM acerca da política de educação superior para os países em desenvolvimento, Otranto (2006) destacou sua sugestão em diversificar também os cursos, com a redução de sua duração. Ainda no governo FHC, esse modelo foi criado com a denominação de curso sequencial, cuja duração era de dois anos. A autora destacou que o referido Banco, em um documento datado de 1999 defendeu que "o sistema de educação superior dos países periféricos deve contar com poucas universidades de pesquisa, seguidas por universidades de formação profissional de quatro anos, institutos isolados e centros vocacionais e/ou de formação técnica com duração de dois anos”. (p. 2). A despeito das ações alinhadas com as orientações previstas pelos organismos internacionais, o governo Lula tomou algumas medidas que foram na contramão dessas orientações, ao regular a abertura de novos centros universitários e desestimular a criação de novos cursos sequenciais. Cabe destacar que o Conselho Nacional de Educação teve bastante dificuldade de explicar o significado desses cursos em abrangência e possibilidades.

Ainda sobre a relação envolvendo os setores público e privado na gestão de Lula, Mancebo (2015) destacou quatro tendências do governo para priorizar o segundo em detrimento do primeiro. São elas:

\footnotetext{
45 Idealizada por Wilhelm Von Humboldt (1767-1835), a universidade humboldtiana se caracteriza por privilegiar a formação humana em todas as suas possibilidades, priorizando a indissociação entre ensino e pesquisa. Em contraposição a esse modelo, tem-se o modelo napoleônico que tem como foco a educação pragmática, que objetiva formar o indivíduo para a vida profissional. O primeiro modelo é de origem germânica e o segundo, nasceu na França.
} 
1- profissionalização da gestão dos estabelecimentos educacionais, substituindo um tipo de administração que era historicamente familiar, pelo gerencialismo, com a introdução dentre outros aspectos do 'reitor profissional';

2- $\quad$ criação de grandes conglomerados ou holdings, com as incorporações de pequenas instituições por grandes organizações, definindo a tendência de formação de oligopólios (número reduzido de grandes empresas que atuam num segmento do mercado), que passarão a ter o controle do mercado da educação superior no país;

3- a financeirização, com a entrada dos grandes conglomerados do setor na Bolsa de Valores;

4- internacionalização - com a participação de capital estrangeiro nas mantenedoras ou nas empresas educacionais - e que remete à desnacionalização da educação no país. (p. 148).

A autora ressaltou que a expansão da educação superior, via setor privado, se deu também pelo "financiamento estatal" indireto, como isenção fiscal (ProUni), financiamento, nos moldes do crédito educativo (Fies) e, ainda, empréstimos financeiros a juros reduzidos, por bancos oficiais, como o Banco Nacional de Desenvolvimento Econômico e Social BNDES. Essas medidas, segundo Mancebo (2015) aprofundam a relação "promíscua" que se estabelece entre governo e mercado educacional. Na sua visão, essas iniciativas transformam a educação em "negócio" e o aluno em "clientes-consumidores", estabelecendo práticas utilitaristas, típicas da lógica capitalista e desconectando a educação de seu papel principal que é a formação para uma consciência emancipadora e crítica.

Pautado pelo olhar dialético, considera-se importante buscar na realidade concreta e objetiva, exemplos que ratifiquem as posições teóricas dos autores retratados nesta pesquisa. Nesse sentido, destaca-se a fala do gestor da instituição privada de educação superior, que foi entrevistado para esse trabalho. Confirmando essa visão mercadológica, retratada por Mancebo (2015) o discurso do entrevistado é essencialmente empresarial, conforme trecho a seguir, quando questionado sobre a expansão e democratização da educação superior sob a perspectiva dos setores público e privado, ele diz que

[...] a expansão do ensino (sic) superior, deixa que a iniciativa privada faz isso com competência, porque o fato de ter que abrir ações em bolsa, das escolas de ensino superior, que está investindo no negócio, o empresário ele não vai montar um negócio de educação superior pra perder dinheiro e uma coisa que o governo, no meu ponto de vista, faz com competência, apesar de todas as críticas é a avaliação do ensino superior. Pelo menos tem algum indicador e esse indicador faz com que os empresários que vem se aventurar (entre aspas) no mercado da educação privada, ele tem que seguir o mínimo de qualidade e a população percebe, aquele aluno que quer entrar no ensino superior, ele quer saber o dia que vai formar [...] (GI1 - informação verbal) 
Em outro momento da entrevista, quando questionado sobre a privatização do acesso à educação superior a partir do texto constitucional de 1988 e da leitura acerca do tema na LDBEN/96, ele diz que

[...] a questão da expansão do ensino privado a partir do momento que há uma estabilidade econômica, que há um potencial grande daquela unidade de negócio, em geral, de conforto, o empresário vai investir. Então você tem acionistas na área da educação que não entendem nada de educação, entendem de ganhar dinheiro. Então eu acho que essa condição de estabilidade econômica fosse a possibilidade de fazer uma parceria de capital nacional com o capital estrangeiro dentro do país e o potencial de crescimento que nós comentamos é de $17 \%$, somente da base de alunos, dos potenciais alunos que estão na iniciativa privada é uma questão de visão de mercado como empresário (GI1 - informação verbal).

Percebe-se que, apesar das perguntas se referirem à expansão da educação superior, o foco da resposta é muito voltado ao olhar mercadológico do tema, qual seja, o interesse do empresário nesse movimento expansionista. O impacto que esse fenômeno teria para o indivíduo e para a sociedade não é enfocado pelo interlocutor. Talvez por isso, haja tanta crítica dos sujeitos acadêmicos em torno da privatização da oferta de vagas nesse nível de educação, como uma opção deliberada do governo.

No entanto, como já destacado, toda ação política é revestida de contradições. Nesse sentido, assim como as tendências e ações citadas por Mancebo (2015) enfrentaram críticas negativas, houve quem tivesse considerado tais medidas necessárias e importantes para tirar o país do profundo déficit educacional em que se encontrava. Por isso, não só os representantes das IES privadas, como grande parte dos beneficiários desses programas, aprovaram tais iniciativas, ao considerá-las contribuições fundamentais para a redução dos entraves que impediam a ampliação e democratização do acesso à educação superior. Nesse sentido, o ProUni, como resultado de uma parceria público-privada, é visto como um programa, atualmente, imprescindível para alcançar as metas estabelecidas pelo PNE 2014/2024.

Para contextualizar o debate que envolveu a necessidade de pensar em ações que permitissem maior democratização do acesso a cursos de graduação, o governo Lula teve como ponto de partida o Plano Nacional de Educação aprovado em 2001, pela lei no 10.172 (BRASILI, 2001). Esse estabelecia como meta, para o fim de 2010, o percentual de $30 \%$ de jovens entre 18 e 24 anos cursando o nível superior. Em 2003, portanto, início de sua gestão, o percentual era de $10,8 \%$.

O governo, pautado por esse objetivo criou a política de expansão das universidades federais - Expandir -, e o Programa Universidade para Todos - ProUni -, no âmbito das 
instituições privadas. Em 2008 lançou o Programa de Apoio ao Plano de Reestruturação e Expansão das Universidades Federais - Reuni. Um ano antes, havia sido lançado o Plano de Desenvolvimento da Educação- PDE $^{46}$ : razões, princípios e programas que detalhava o modelo de política educacional que estava sendo implementada em seu governo. Para Krawczyk (2008), o PDE apresentava-se

[...] como uma política nacional e um arranjo institucional resultante de uma revisão das responsabilidades da União, que passa a assumir o compromisso do combate às desigualdades regionais e da construção de um mínimo de qualidade educacional para o país. Adjudica ao governo federal o papel regulador das desigualdades existentes entre as regiões do Brasil por meio de assistência técnica e financeira, de instrumentos de avaliação e de implementação de políticas que ofereçam condições e possibilidades de equalização das oportunidades de acesso à educação de qualidade. Por sua parte, os estados, principalmente, os municípios assumirão o compromisso pelo desenvolvimento educacional em seus "territórios". (p. 802).

Alguns especialistas consideraram que o lançamento do PDE foi uma tentativa de suplantar o PNE, este considerado uma política de Estado e, aquele, uma política de governo. No entanto, sobre o Plano de Desenvolvimento da Educação e a comparação com o Plano Nacional de Educação, Krawczyk (2008) destacou o posicionamento do então ministro da educação, Fernando Haddad, ao dizer que "uma das inovações importantes do PDE é o acréscimo de metas qualitativas e intermediárias às metas quantitativas já estipuladas no Plano Nacional de Educação - PNE” (p. 803).

Ainda sim, o Plano não deixou de receber críticas por sua falta de diálogo com o Plano Nacional de Educação vigente. Para Saviani (2007), ao adotar o nome de Plano, o governo projetou a ideia de que se tratava de um documento que substituiria o PNE, "ainda que, de fato, este permaneça, de modo geral, solenemente ignorado”. (p. 1241).

Para explicar o plano (PDE) de Fernando Haddad, o autor destacou dois pontos - um positivo e outro negativo. Quanto ao primeiro, ele ressaltou a singularidade do PDE em relação à preocupação "em atacar o problema qualitativo da educação básica brasileira"

\footnotetext{
${ }^{46}$ O PDE foi lançado em 24 de abril de 2007 como um plano plurianual (2008/2011) em que reuniam 52 ações, incidindo sobre os diferentes níveis de ensino, visando a qualidade da educação. (KRAWCZYK, 2008). Simultaneamente ao lançamento do programa, foi promulgado o Decreto $\mathrm{n}^{\circ}$ 6.094, dispondo sobre o 'Plano de Metas Compromisso Todos pela Educação', que, segundo Saviani (2007), seria o "carro-chefe" do Plano. Para ele, o PDE "aparece como um grande guarda-chuva que abriga praticamente todos os programas em desenvolvimento pelo MEC". (p. 1233). O "Compromisso Todos pela Educação" é um movimento da sociedade civil constituído por um aglomerado de grupos empresariais com representantes e patrocínio de entidades como o Grupo Pão de Açúcar, Fundação Itaú-Social, Fundação Bradesco, Instituto Gerdau, Grupo Gerdau dentre outros. Tal iniciativa definiu cinco metas, todas voltadas à educação básica. Como esse nível de educação não foi abordado (diretamente), nesse trabalho, optou-se por não detalhar as referidas metas. No entanto, para mais detalhes, ver Saviani (2007, p. 1244).
} 
(p.1241) traduzido em três programas: Índice de Desenvolvimento da Educação Básica (Ideb), Provinha Brasil e o Piso do Magistério ${ }^{47}$.

O ponto negativo, apontado por Saviani (2007), estava relacionado à configuração do documento. $\mathrm{O}$ autor criticou sua nomenclatura ao destacar que o PDE não era um Plano, mas sim, um "Programa de ação". Para ele, o referido documento não se revestiu de organicidade, ou seja, não estava imbuído da "ideia dos planos educacionais como instrumentos de introdução da racionalidade na ação educativa, entendida esta como um processo global que articula a multiplicidade dos seus aspectos constitutivos num todo orgânico". (p. 1242). No entanto, um dos pontos destacados pelo então ministro Haddad, ao lançar o PDE, foi o caráter sistêmico de educação desse, em que as políticas previstas e descritas faziam parte de um todo integrado e articulado.

A oferta de educação superior, pelo setor privado, descrito no referido documento, destacou o papel das políticas de financiamento e concessão de bolsas. Segundo o governo, essa parceria "promove inovações consideráveis no mecanismo de financiamento do estudante do ensino superior não-gratuito" ao criar uma "articulação estrutural" entre o Fies e o ProUni. (BRASIL, 2007). Para o governo, essa foi uma das ações que contribuíram para o processo de democratização do acesso a esse nível de educação.

Essa parceria público-privada, presente nas políticas de educação superior e que predominou tanto no governo de FHC como no de Lula, com a consequente expansão de sua oferta, foi analisada por Gomes e Moraes (2012) da seguinte forma:

[...] a partir de 1995, início do Governo FHC a ES passa a apresentar taxas crescentes de expansão, tendo continuidade no Governo Lula. Gostaríamos de chamar a atenção para o ciclo ascendente de expansão da ES que caracteriza os dois governos, sob políticas públicas que expressam evidentes continuidades e importantes diferenças. (p. 179).

Apesar de a política de educação superior do governo FHC já ter sido abordada neste trabalho, vale a pena, para efeito de comparação com o governo Lula, resgatar outros princípios e ações. Sempre alinhada às recomendações dos organismos multilaterais, conforme destacado por Carvalho (2015), a diversificação na oferta de cursos tornou-se essencial na política de expansão de vagas na gestão do presidente Fernando Henrique Cardoso. Segundo a autora,

\footnotetext{
${ }^{47}$ Os três programas da educação básica, destacado por Saviani (2007) não foram detalhados neste trabalho, por não ser, esse nível de educação, foco dessa pesquisa.
} 
[...] no intuito de aumentar a escolaridade líquida tornava-se necessário dar oportunidade educacional às camadas mais pobres e de trabalhadores em cursos não tradicionais, mais curtos e voltados, precipuamente, ao mercado de trabalho. Para atingir esse objetivo, foram criadas três modalidades de cursos: sequencial, tecnológico e a distância. (p. 77).

Esses cursos se caracterizaram pelo reduzido custo e rápida duração, atendendo às necessidades das classes economicamente mais baixas da população, que esperavam conseguir melhores condições de trabalho ao concluir um curso de graduação ou tecnológico. Com exceção dos cursos sequenciais que foram perdendo espaço devido a incapacidade do CNE de definir, com clareza, suas características e seu alcance, os outros dois tipos se consolidaram, sobretudo, no final da gestão de Lula. Sobre o caráter dado a esses cursos no referido governo, Carvalho (2015) ressaltou que "em linha diferente da gestão FHC, no governo Lula a ideia central era recuperar o papel de protagonismo dos Centros Federais de Educação Tecnológica $\left(\mathrm{CEFET}^{48}\right)$ na oferta desta modalidade de ensino (sic).” (p. 83-84).

A diversificação institucional e de cursos que caracterizou tão fortemente os dois governos abordados, teve destaque com a evolução dos cursos superiores de tecnologia (CST), que tiveram crescimento pujante a partir de 1997. Assim como previsto na LDBEN de $1996^{49}$, a possibilidade de novas modalidades de graduação motivou a expansão desse tipo de curso. Tanto na esfera privada quanto pública, o número de instituições que passaram a ofertar esse tipo de curso aumentou de forma significativa. Aliado ao caráter profissionalizante dos CST e, alinhando-se ao modelo sugerido pelos organismos internacionais, essa tendência se consolidou, mesmo com progressiva redução, a partir de 2005.

Segundo analisou Sousa (2015), a partir de dados do Censo da Educação Superior realizado em 1998 e 2014, o crescimento desses cursos atingiu a taxa de $3000 \%$ entre os anos de 1997 e 2012. Em termos absolutos, significou que naquele ano havia 194 Cursos

\footnotetext{
${ }^{48}$ O Decreto $\mathrm{n}^{\text {o }} 5.773$ de 9 de maio de 2006 dispôs sobre os CEFET em seu Art. 77, $\S 1^{\circ}$ como sendo "instituições de ensino superior pluricurriculares, especializadas na oferta de educação tecnológica nos diferentes níveis e modalidades de ensino, caracterizando-se pela atuação prioritária na área tecnológica" (BRASIL, 2006b). Em 24 de abril de 2007 o governo publicou o Decreto $\mathrm{n}^{\circ} 6.095$ estabelecendo diretrizes para a integração de instituições federais de educação tecnológica, dentre elas os CEFET, com o objetivo de constituir os Institutos Federais de Educação, Ciência e Tecnologia - IFET, para compor a Rede Federal de Educação Tecnológica. (BRASIL, 2007b).

${ }^{49}$ Sobre a normatização dos cursos superiores de tecnologia, Sousa (2015) destacou que a LDBEN de 1996 não tratou especificamente dessa modalidade, (não com essa nomenclatura) e que foi a partir do Decreto $\mathrm{n}^{\circ}$ 2.208/97 que houve a diferenciação dos níveis básico, técnico e tecnológico e que foi indicada a organização curricular do ensino profissional. Segundo o autor, "[...] integrando-se à educação superior, o nível tecnológico equivale a cursos desse nível educacional na área tecnológica. A educação profissional tecnológica é regulada pela legislação referente ao nível superior, e direcionada aos egressos do ensino médio e técnico [...]” (p. 138).
} 
Superiores de Tecnologia e em 2012 o número chegou a 5.696. O autor destaca, contudo, que a referida evolução foi marcada por diversas oscilações e que o ápice desse crescimento deuse entre 2003 e 2004. A partir daí, o movimento foi de redução sistemática, mantendo taxas bem menores de expansão. Em 2013, o índice de progressão desses cursos foi de apenas 6,5\%. Para Sousa (2015), essas oscilações são explicadas por diversas razões, dentre elas "as vocações das instituições que os ofertam, a relação com o mercado de trabalho, a situação econômica do país e a própria visão que a sociedade tem dos cursos em análise”. (p. 141-142).

Outra modalidade educacional que se apresentou como forte opção para promover a democratização do acesso foi a educação a distância - EaD. O governo Lula considerou essa possibilidade fundamental para alcançar uma população impossibilitada de frequentar uma IES, "em face das dimensões continentais do país e das enormes desigualdades e carências" (p. 84). A partir desse raciocínio, foi criada a Universidade Aberta do Brasil - UAB. Os cursos seriam ofertados, em regime de colaboração entre a união, estados e municípios, por instituições públicas, articulados com polos de apoio presencial. Para o governo, o objetivo era "expandir e priorizar a oferta de cursos e programas de educação superior no país" (CARVALHO, 2015, p. 84).

A educação a distância se consolidou como mais uma forma de diversificação do sistema. Assim como os cursos de graduação presenciais e os CST, a EaD também abrangeu as redes pública e privada. Duas características contribuíram para diferenciar a oferta de cursos, por essa modalidade educacional, a partir da dependência administrativa. Segenreich e Neves (2015) destacam a criação de novos tipos de instituições e o surgimento de outros arranjos organizacionais como marcas dessa particularidade.

Os centros universitários e os grupos educacionais (instituídos a partir de fusões/parcerias e incorporações) estão para o setor privado, como os institutos federais de ciência e tecnologia e os consórcios de IES estão para o setor público. Foram esses arranjos que segundo os autores, definiram o modelo de EaD instituído no Brasil, resultando em um forte crescimento de matrículas nessa modalidade. O censo de 2013 (INEP, 2015) informa que um milhão, seiscentas e trinta e oito mil novas vagas (1.638.000), em EaD foram oferecidas. Dessas, um milhão, quatrocentos e vinte e nove mil (1.429.000) tiveram as inscrições concluídas. Desse processo, foram formalizados quinhentos e quinze mil (515.000) matrículas, ou seja, um terço do número de vagas e inscritos. (SEGENREICH; NEVES, 2015). Sobre a ampliação do acesso a educação superior, partir de cursos à distância, os autores destacam que 
[...] o Brasil viveu em décadas passadas a impossibilidade do acesso à universidade. Hoje a sociedade vê atendida a sua solicitação de fácil acesso ao ensino superior ( sic). Garante-se o acesso, mas não a permanência nem a conclusão de um curso. No que se refere às vias alternativas de expansão da $\mathrm{EaD},[\ldots]$ ficou claro que há muito campo de pesquisa sobre a diversificação das arquiteturas acadêmicas que estão se delineando com a criação de novos tipos de organização, novos cursos e novos arranjos institucionais. (p.131).

Como uma política que se pretendeu promover a democratização do acesso à educação superior, o ProUni também previu a oferta de bolsas em cursos de EaD. Entre os anos de 2005 e 2014 houve um milhão duzentas e setenta e três mil, trezentos e vinte e dois (1.273.322) bolsistas de cursos presenciais, sendo duzentos e vinte e três mil, novecentos e três (223.903) bolsistas da modalidade a distância, o que correspondeu a 15\% do total (MEC, 2015).

Percebeu-se, no entanto, que o número de bolsistas da modalidade a distância significou fatia pequena, comparada ao número de matrículas realizadas pelo setor privado, em cursos dessa natureza. Apenas no ano de 2013 foram realizadas novecentas e noventa e nove mil e dezenove (999.019) matrículas em EaD nas IES privadas, num total de um milhão cento e cinquenta e três mil quinhentas e setenta e duas (1.153.572) matrículas nessa modalidade (pública e privada) (INEP, 2015). Os cursos a distância, nesse ano, representaram um percentual de 18,59\% em relação ao total de matrículas (presencial e EaD) do setor privado (5.373.450) e, em relação ao total de matrículas nas graduações a distância (público e privado), aquele setor abarcou 86,60\% em 2013.

Esses números demonstraram que a hegemonia do setor privado está presente tanto na oferta de cursos presencias quanto a distância, mas que, em termos de bolsas ProUni, o número é pouco significativo, quando comparado ao número total de oferta. Para melhor visualização, apresenta-se, a seguir, o gráfico 5: 
Gráfico 5: Número de matrículas de graduação por modalidade de educação e categoria administrativa - 2013

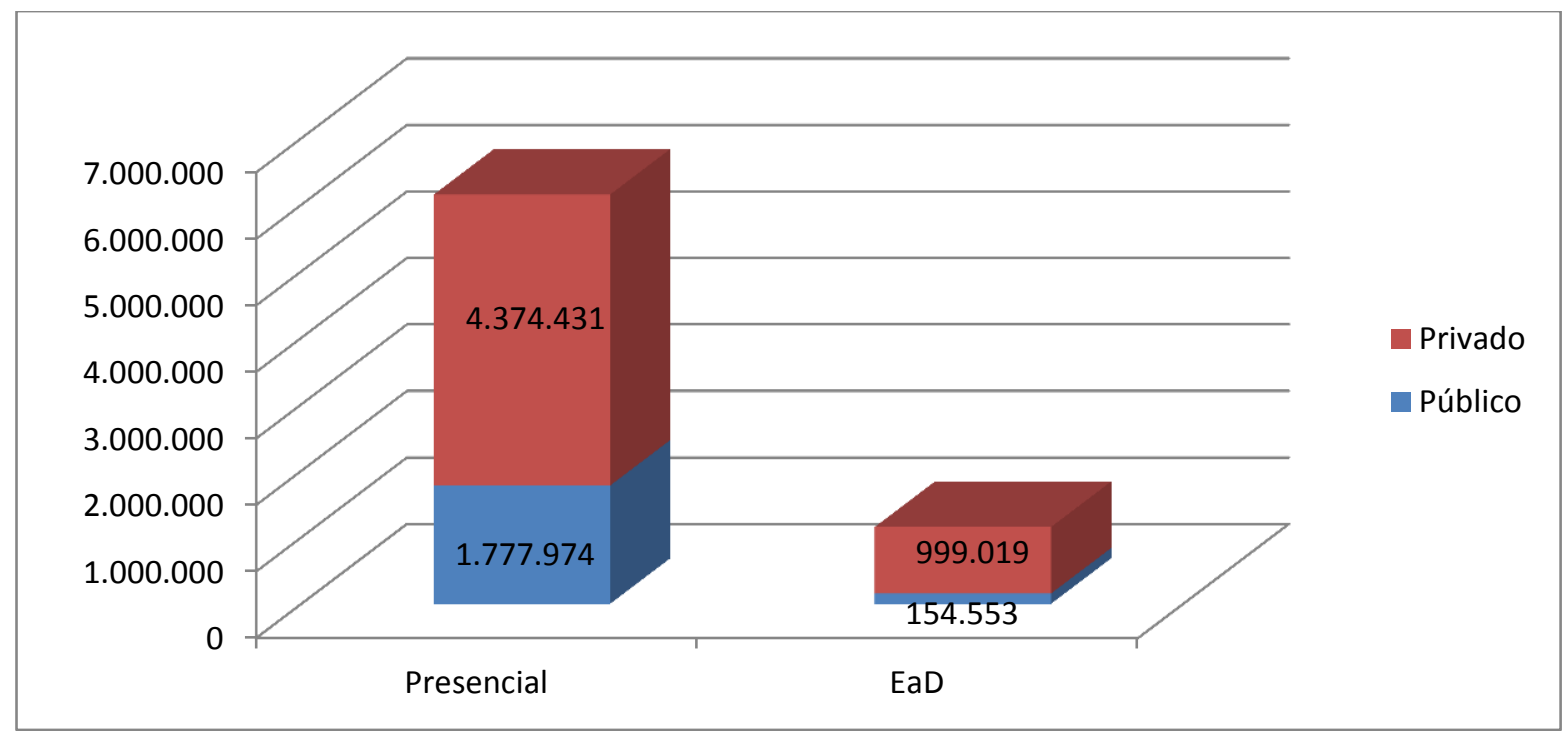

Fonte: INEP (2015). Dados: Censo da Educação Superior, Resumo Técnico 2013. Elaboração Própria.

Apenas para efeito de comparação, segue gráfico com o número de bolsistas nas duas modalidades analisadas, durante os dez anos do Programa Universidade para Todos - 2005 a 2014. Se considerar que em apenas um ano (2013) o setor privado efetuou quase um milhão de matrículas em EaD, os 223 mil bolsistas da modalidade, acumulados em dez anos de programa, representam pouco para o sistema.

Gráfico 6 - Bolsistas ProUni, por modalidade de educação- 2005 a 2014

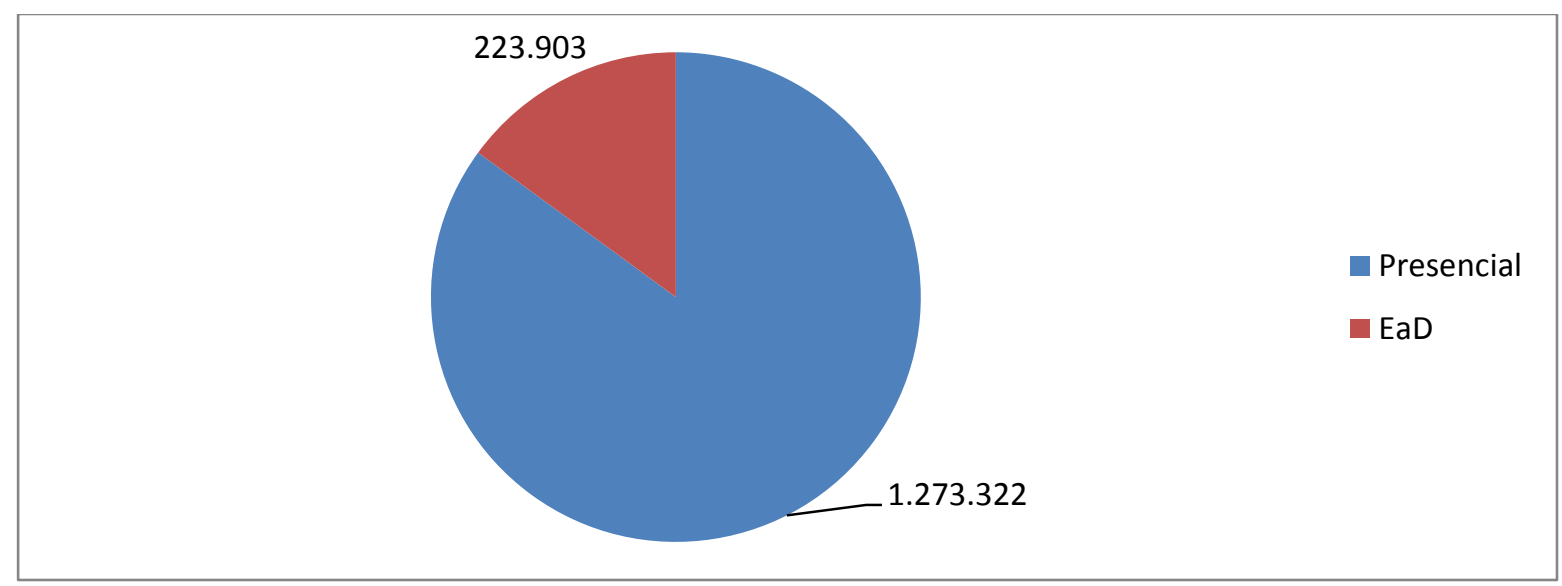

Fonte: MEC; Dados: Sisprouni. Elaboração própria

Caso os cursos de educação à distância se consolidem como uma modalidade que promova, de fato, a democratização do acesso à educação superior com qualidade, o que envolveria mais rigor da política de avaliação do MEC, repensar a oferta desses cursos, 
sobretudo por meio das bolsas ProUni, apresenta-se como uma alternativa viável para a inclusão de mais pessoas cursando o nível superior. No entanto, essa possibilidade enfrentaria duas resistências por parte dos defensores do setor público como a melhor alternativa para a oferta da educação superior: 1) fortalecimento ainda maior do setor privado; 2) o crescimento da $\mathrm{EaD}$ como alternativa à educação presencial, fato que não é nem de longe uma unanimidade.

Ainda sobre as semelhanças entre os governos FHC e Lula e a democratização do acesso à educação superior, reitera-se que o setor público não foi totalmente desprezado por esse, como foi por aquele. Ao abordar o assunto, Carvalho (2015) diz que "FHC defendeu que não havia necessidade de criação de novos estabelecimentos federais, sobretudo universidades [...]. Como se poderia esperar, nenhuma universidade federal foi criada até o último ano do segundo mandato". (p. 79).

A despeito das semelhanças identificadas entre os governos citados, Lula imprimiu maior atenção ao setor público, como já foi aqui destacado. Diversas instituições federais de educação superior - IFES surgiram por fusão, federalização ou criação de novas, a partir de políticas como o Expandir e o Reuni. Segundo a autora, dentre os compromissos de campanha de Lula

[...] estava priorizar o modelo universitário público por contemplar os princípios fundamentais da autonomia universitária e da indissociabilidade entre ensino, pesquisa e extensão. A ação estatal caminhou neste sentido por meio da criação de novas universidades federais e da construção de novos campi nas já existentes. (p. 85).

Apesar desse movimento, ao comparar as taxas de crescimento da matrícula - TCM de 1995 a 2008, Gomes e Moraes (2012) destacaram o protagonismo do setor privado, tanto no governo de FHC, quando no de Lula. Desmembrando os dois períodos, verificaram uma taxa de crescimento de 129,3\% nas matrículas do setor privado, no período entre 1995 e 2002 (os oito anos do governo FHC), e uma taxa de 50,1\%, no mesmo período, pelo setor público. Já no período que compreende os anos de 2002 a 2008 (o último ano do governo FHC e os seis primeiros anos do governo Lula), a taxa de crescimento foi de 38,4\% do setor privado, e de $12,1 \%$ do setor público. Para os autores, "tais dados são suficientemente robustos para sustentar a tese de continuidade na política de expansão durante os governos FHC e Lula” (p. 183). Para melhor percepção do caráter privatista na oferta de vagas dos cursos de graduação, faz-se interessante a visualização das taxas de matrículas aqui expostas, observando o gráfico a seguir. A representação contempla tanto o governo de FHC quanto o de Lula. Ressalva-se 
apenas que o período abordado é diferente para cada governo. O primeiro teve abarcado os dois mandatos (1995-2002), já o segundo, foi abordado todo o primeiro mandato e metade do segundo (2002-2008):

\section{Gráfico 7: Representação percentual da evolução de matrículas nos setores públicos e privados Brasil}

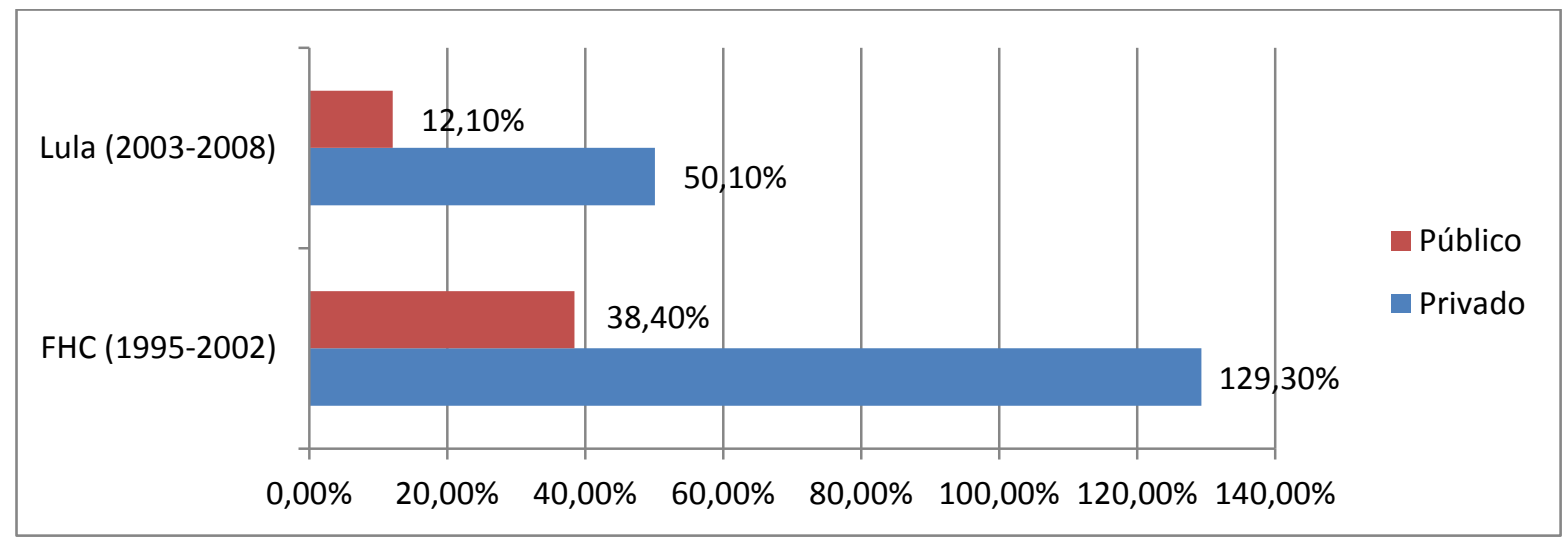

Elaboração própria a partir de dados de Gomes e Moraes (2012, p. 183).

O ponto de convergência identificado pelos autores, acerca do perfil privatista que caracterizou a política de expansão do acesso à educação superior no país, nos governos FHC e Lula, foi analisado à luz de outro conceito, que não o da democratização: a equidade ${ }^{50}$. Isso, porque a ampliação do número de vagas, pura e simplesmente, realizado no governo FHC, não garantiu o ingresso de pessoas de baixa renda, assim como de grupos historicamente alijados dos bancos das IES. Além da ampliação da oferta, o governo Lula criou políticas que resultaram em mais democratização do acesso, entendida num sentido mais amplo, com políticas que beneficiaram as camadas sociais menos favorecidas. Nesse bojo pode-se incluir o ProUni como uma dessas ações, ao incluir, na lei que o instituiu, a previsão de cotas para esses cidadãos. Ao analisar o caráter equitativo do governo Lula, a partir de seu modelo de Estado, Borges (2015) considerou que

[...] a diferença fundamental nas políticas públicas definidas a partir da reconfiguração do Estado brasileiro, em 2003, com o governo de Lula. [é que] $\mathrm{O}$ conceito de equidade ganha a centralidade do arcabouço normativo

\footnotetext{
${ }^{50}$ Interessou a essa dissertação, trabalhar com os conceitos: democratização e equidade, a partir da ideia de justiça social, em que a política pública tenha sido capaz de alcançar as pessoas com maiores fragilidades socioeconômicas e pertencentes a grupos historicamente mantidos em condições de subordinação e esquecimento, como os pobres, negros, indígenas, pessoas com deficiência, dentre outros. Na verdade, a abordagem foi no sentido de identificar o quanto as políticas de democratização no governo Lula trataram os desiguais, desigualmente, criando assim, condições equitativas para a promoção do equilíbrio social.
} 
das políticas de desenvolvimento com o intuito de promover justiça social. Para isso, busca-se a redução de desigualdades e distribuição de renda sem que isso seja entendido como uma ameaça ao equilíbrio econômico (p. 62).

É fato que políticas que promovam melhores condições de vida às pessoas fazem-se urgentes. Os entraves presentes no interior do sistema educacional brasileiro, sejam na educação infantil, básica ou superior, precisam ser atacados, pois um país que não cuida da formação das suas crianças, jovens e adultos não avança econômica e socialmente, não supera suas iniquidades e não promove a emancipação do indivíduo. Nesse sentido, investir em programas que visem reduzir as desigualdades, de toda ordem, presentes em nossa sociedade deveria ser questão central de todo governo. Os déficits nos índices educacionais brasileiros precisam ser encarados com seriedade e o Estado deve ser o protagonista na realização de ações que busquem reduzir essas deficiências.

Com um contexto bastante negativo, a educação brasileira está aquém de países, com nível de desenvolvimento abaixo do nosso, como alguns de nossos vizinhos sul-americanos. O acesso à educação superior brasileira ainda não atingiu o sistema de massas, conforme denominação utilizada por Trow ${ }^{51}$, segundo Ristoff (2014). Isso significa que no Brasil ainda não se tem $30 \%$ de jovens, entre 18 e 24 anos estudando numa instituição de educação superior. Pior do que isso, o país não é representado em sua inteireza, pelos estudantes que cursam uma graduação. A heterogeneidade racial e social não se reflete nos bancos das universidades. Daí, a necessidade urgente de se criar políticas públicas que promovam esse fenômeno, aqui denominado de democratização do acesso à educação superior, com equidade.

Vários foram os motivos que colocaram o Brasil em situação deficitária com relação ao acesso à educação superior. A insuficiente quantidade de vagas nas universidades públicas (fato que gera grande concorrência) e a dificuldade em arcar com os custos das instituições privadas, foram algumas consequências que resultaram nos baixos índices de acesso a esse nível educacional. No entanto, a deficiência na educação básica foi considerada como uma das principais razões que dificultaram o ingresso dos jovens na educação superior. Sobre o assunto, Neves, Raizer e Fachinetto (2007) afirmaram que

[...] compreendida esta realidade básica e tendo em vista que a razão principal da iniquidade do acesso ao ensino superior (sic) continua sendo o insucesso dos níveis anteriores de ensino com relação à inclusão social é

\footnotetext{
${ }^{51}$ Martin Trow (ex-professor da Universidade de Berkeley) elaborou uma classificação em que "considera de elite o sistema de educação superior com acesso para até $15 \%$ dos jovens de idade apropriada. [...] massas o sistema que permite acesso para entre $16 \%$ e $50 \%$ dos jovens de idade apropriada [...] a partir de $50 \%$, Trow considera o sistema de acesso como universal" (RISTOFF, 2014, p. 726).
} 
possível estabelecer condições melhores de abordagem e compreensão do que se tem passado com a educação superior no país. (p. 138).

Portanto, para além das políticas públicas direcionadas à democratização do acesso à educação superior, o Estado deve, cada vez mais, investir na base do sistema, com programas que universalizem, de fato, o acesso a educação de qualidade. Os jovens e adultos que estão fora da faixa etária (defasagem idade/série) também devem ter a atenção necessária do governo, a fim de que se promova a redução das desigualdades educacionais, tão perversas à sociedade brasileira.

Algumas questões suscitadas pelos autores despertaram reflexões importantes acerca da democratização do acesso à educação superior com equidade. Considerando que esse tema se reflete na análise sobre os desafios que esse nível educacional enfrenta, sobretudo nos países em desenvolvimento, vale a pena olhar para os pontos destacados, com a percepção de que o debate é mais relevante do que se pode pensar. O diálogo entre governo e sociedade deve superar as discussões e disputas político-partidárias. A partir dessa avaliação, a pesquisadora considerou importante trazer a tona os questionamentos desses autores, que são:

a) o processo de expansão do ensino superior (sic) tem assegurado mais acesso à educação superior de qualidade?

b) em que medida a diferenciação da oferta de oportunidades de educação pós-secundária e superior podem facilitar a democratização do acesso?

c) como e em que extensão as políticas afirmativas e de inclusão social estimulam a democratização do acesso. (p. 142-142).

Pesquisas relacionadas ao ProUni apresentaram números que demonstraram sua capacidade em, não só ampliar, mas também democratizar o acesso aos cursos de graduação, ao promover a formação de milhares de jovens com qualidade. Segundo a Associação Brasileira para o Desenvolvimento da Educação Superior - Abraes (2014) ${ }^{52}$ o resultado de seu levantamento mostrou que "ao lado do desempenho acadêmico, a bolsa ProUni apresenta o maior impacto, produzindo um aumento médio de 10 pontos nos resultados do Enade em relação ao aluno típico médio (ABRAES, 2014, p. 1). Ao analisar os últimos vinte e um anos de política de educação superior no país Ristoff (2013) destacou que

\footnotetext{
52 A Abraes - Associação Brasileira para o Desenvolvimento da Educação Superior realizou uma pesquisa intitulada, Instituições particulares de ensino superior e ProUni: o impacto do programa de inclusão sobre o desempenho de seus alunos no Enade. O estudo mostrou que, em geral, o desempenho dos bolsistas é superior ao dos não-bolsistas, considerando variáveis como tempo de estudo, escolaridade dos pais, renda e trabalho (ABRAES, 2014).
} 
[...] os dados do Questionário Socioeconômico dos dois primeiros ciclos do ENADE, [...], confirmam que o Brasil vive um período não só de expansão da educação superior, mas também de democratização, mostrando melhorias significativas na inclusão de jovens pretos, pardos, de baixa renda, de estudantes trabalhadores, filhos de pais com baixa escolaridade e oriundos da escola pública (p. 47).

Nesse sentido, o Programa Universidade para Todos - ProUni contribuiu com esse processo, ao prevê, na lei que instituiu o Programa, a oferta de bolsas integrais ou parciais, a estudantes carentes, com a previsão de cotas àqueles negros, de origem indígena e pessoas com deficiência em instituições privadas de educação superior. Como contrapartida, o governo abria mão de impostos e contribuições para subvencionar as IES.

Apesar do caráter democratizante dessa política, seu perfil privatista não agradou àqueles que defendem a educação pública, pois consideram que o governo abre mão de recursos públicos, para beneficiar o setor privado. É nesse sentido que houve a comparação entre os governos Lula e FHC, para que pudesse ser traçada uma linha de continuidade entre os dois, em relação a esse tema.

A gestão de Fernando Henrique, ao considerar a educação superior uma atividade pública não-estatal e, mais do que isso, um serviço, segundo o conceito dos organismos internacionais, atendeu às orientações de instituições como o Banco Mundial (BM), que sugeria que a oferta de vagas desse nível de ensino fosse plenamente compatível com a lógica privatista proposta pelo governo. Assim, Sousa (2013) considerou que

[...] com efeito, a expansão privatista das vagas e mercantilização do sistema foram alguns dos traços mais marcantes da educação superior brasileira, na década de 1990. Essas características fundamentais ajudaram a delimitar o perfil desta atividade no meio social e contribuíram para determinar o caminho mais voltado, provavelmente, para o atendimento de trabalho e aos interesses econômicos. (p. 36)

Observando essa tendência privatista de FHC, foram feitas as seguintes indagações: afinal, por que Lula optou por dar continuidade à lógica privatista, no que diz respeito à educação superior? Por que o setor privado continuou como protagonista na oferta desse nível de ensino? Como fica a questão da democratização do acesso?

Pode-se dizer que os organismos multilaterais tiveram papel significativo na lógica mercantil implementada pelo governo FHC e Lula. Relatórios do BM, conforme citado por Otranto (2006), já identificavam a educação superior como serviço e, mais do que isso, sugeriam que os governos periféricos gastassem menos com esse nível de ensino e mais com a 
educação básica. Além disso, é fato a pressão exercida pelo setor privado, sobretudo pelos grupos estrangeiros de educação superior, para entrarem, cada vez mais, no mercado nacional para ofertar esse tipo de "serviço".

A despeito das semelhanças com seu antecessor, o governo de Luiz Inácio Lula da Silva criou políticas com o objetivo de expandir, democratizar e incluir mais pessoas nas instituições de educação superior. Seus programas de expansão, como o Reuni e o ProUni, foram seguidos por políticas afirmativas que possibilitaram o ingresso de pessoas de baixa renda, negros (pretos e pardos), indígenas e pessoas com deficiência. No entanto, sobre o assunto, Ristoff (2014) faz a seguinte ponderação:

[...] se já é perceptível a mudança de perfil no campus das Instituições privadas de Educação Superior, em função de políticas públicas como o ProUni [...], há que se ter clareza de que muito ainda tem que ser feito para que esta mudança se estenda efetivamente a todos os cursos de graduação, em especial de alta demanda, para que se possa ter um campus mais justo e com mais cara de Brasil. (p. 745).

O autor tem razão quando diz que ainda há muito a se fazer, pois a história educacional brasileira, sobretudo a de educação superior caracterizou-se por seu elitismo, mantendo fora dos bancos universitários, parcela considerável da população. O Estado, diante das deficiências no setor, despertou tardiamente para essa realidade, mas, é inegável que nos últimos anos alguns esforços foram feitos para reduzir tamanho déficit social. Apesar da lógica empreendida por essas políticas de educação superior, em atender aos ditames dos organismos internacionais e a motivação capitalista desses, alguns avanços foram perceptíveis.

Outras ações foram adotadas para democratizar o acesso às IES como a modificação do Fies, que a partir de 2004 teve a legislação alterada para incluir o critério de raça/cor entre as variáveis do cálculo do índice de classificação. Segundo dados do Instituto de Pesquisa Econômica Aplicada - Ipea, a modificação resultou no acesso a 36.000 negros ao fundo de financiamento à educação superior. Essa política, associada ao ProUni, "pode ter impactado no aumento desses estudantes na educação superior [...], do acumulado de bolsas do ProUni, entre 2005 e 2010, 48\% foram destinadas a estudantes negros(sic) e pardos. A desigualdade foi reduzida, em termos relativos[...]" (CARVALHO, 2015, p. 88). Já no período de 2005 a 2015, esse índice aumentou para 50,8\% (MEC, 2016).

Como já era previsto, as políticas educacionais de Lula foram mantidas no governo de Dilma Vana Rousseff (2011-2014). Com destaque para o ProUni, que continuou ofertando 
bolsas e contribuindo para a ampliação de vagas e matrículas na educação superior, outras ações foram tomadas para democratizar o acesso a cursos de graduação no país, como a instituição da Lei de Cotas, que significou importante avanço na direção das políticas inclusivas. Outros programas foram criados em seu primeiro mandato, mas o Reuni e o ProUni continuaram sendo as principais ações no âmbito da educação superior, como será visto no próximo subtítulo.

\section{5 - Dilma Vana Rousseff (2011-2014) e as políticas de acesso e permanência na educação superior: velhos e novos desafios}

O governo da Presidente Dilma Vana Rousseff manteve a política de educação superior iniciada por Lula, ao optar pela continuidade de políticas como o Reuni, o ProUni e o Fies - Fundo de Financiamento Estudantil, contemplando tanto a esfera pública quanto a privada. No entanto, além das políticas citadas, foram criados outros programas, como o Ciências sem Fronteiras - CsF, "que visa estimular a mobilidade de estudantes, professores e pesquisadores mediante a concessão de bolsas para as áreas consideradas prioritárias/estratégicas em universidades estrangeiras.” (FERREIRA, 2012, p. 466) Pode-se dizer que esse Programa faz parte de um outro movimento da política de educação superior do país, voltada à internacionalização do conhecimento como meio de expandir o intercâmbio entre os estudantes e os países.

Apesar das políticas de expansão desse nível educacional, o problema relacionado ao acesso continuou presente, assim como a preocupação com a qualidade e a permanência passaram a fazer parte da agenda do governo e dos anseios da sociedade de forma mais sistemática. O novo PNE confirmou em seu texto que além dos antigos objetivos (expansão e democratização do acesso) que ainda não foram superados, há outros que se impõem (qualidade e permanência). Como estratégia, determinou-se a vinculação dos recursos à qualidade. Além disso, o ProUni foi citado, no referido plano, como ação para enfrentar os velhos e os novos desafios da educação superior brasileira. As estratégias 12.9 e 12.20 descrevem a intenção do Estado em reduzir as assimetrias sociais que perduram.

[...] ampliar, no âmbito do Fies e do ProUni, os benefícios destinados à concessão de financiamento a estudantes regularmente matriculados em cursos superiores presenciais ou a distância, com avaliação positiva, conduzidos pelo Ministério da Educação; e ampliar a participação proporcional de grupos historicamente desfavorecidos na educação superior, 
inclusive mediante a adoção de políticas afirmativas, especialmente na forma da Lei $n^{\circ}$ 12.711/2012 e Decreto $n^{\circ} 7.824 / 2012$ (MEC, 2016).

Nesse sentido, percebe-se a preocupação impressa no documento, não só em ampliar as vagas na educação superior, mas fazê-lo com inclusão social. Para tanto, cita a política de cotas e seu respectivo decreto, como normas que subsidiam ações dessa ordem. O primeiro mandato de Dilma Rousseff seguiu essa lógica ao dar continuidade às políticas que foram nessa direção, como o próprio ProUni, assim como o Reuni e o lançado CsF.

No entanto, a discussão em relação ao peso que o setor privado continuou tendo na política educacional do governo Dilma, manteve-se presente. Em relação ao seu antecessor, os programas de educação superior, de alguma forma, coadunaram com as iniciativas implantadas por Fernando Henrique Cardoso no que diz respeito ao fortalecimento da esfera privada. Dentre os motivos já conhecidos (continuidade das parcerias público-privadas), a fusão e aquisições, por meio de abertura do capital, de empresas educacionais, iniciadas em 2007, foram ampliadas em sua gestão (CARVALHO, 2015, p. 89).

Ao analisar esse movimento, a autora relatou preocupação em relação à regulamentação desse segmento que, segundo ela, vem crescendo por meio de fusões e aquisições, com a pulverização do capital na bolsa de valores. Isso traz consequências não só no campo educacional, como também no político, por meio da capacidade que essas empresas têm de pressionar os agentes políticos em nome de seus interesses. Sobre o assunto, Carvalho (2015) destacou que o

[...] fenômeno recente que não pode ser ignorado é o movimento multifacetado de financeirização, oligopolização e internacionalização da educação superior brasileira. A despeito da nova feição do processo de mercantilização apresentar-se restrito a poucas Instituições de Educação Superior privadas mercantis, porém estas têm peso significativo no cômputo das matrículas e de cursos. O caráter mercantil no nível superior torna-se central tanto no que tange à interferência política no processo decisório, através da atuação de lobbys e de bancadas no Congresso Nacional financiados pelos grupos com maiores recursos econômicos, como pelas dificuldades enfrentadas pelo Poder Público em neutralizar o avanço do movimento de concentração e internacionalização do capital no setor inerente às atividades econômicas mais pujantes sob o domínio do capitalismo globalizado e oligopolista (p. 91-92).

Para regulamentar essas empresas educacionais e o setor privado, em geral, foi pensado um instituto que seria responsável por essa função. No entanto, o projeto de lei ${ }^{\circ}$ 4.372 de 2012 que o instituiu está parado na Comissão de Constituição e Justiça e de 
Cidadania desde 07 de abril de 2015. Para a autora, a institucionalização do Instituto Nacional de Supervisão e Avaliação da Educação Superior - INSAES “é fundamental para frear os negócios educacionais que, inclusive, usam como aval no relacionamento com seus acionistas a adesão da maioria dos estudantes ao ProUni e ao Fies”. (p. 92).

Segundo a autora destacou, se o governo Lula deu prioridade ao ProUni, ao que tudo indica, o governo Dilma priorizou o Fies como programa capaz de alterar o quadro preocupante relacionado à taxa de escolarização dos jovens brasileiros. Nesse sentido, pode-se considerar que a relação público-privada manteve-se forte em seu governo, com o Fundo de Financiamento Estudantil sendo o protagonista no processo de democratização do acesso à educação superior.

Nesse sentido, Lima (2015) afirmou que "foi mantida a política de fortalecimento do setor privado, considerando o aumento significativo de IES privadas no referido período, conduzido, inclusive, pelas alterações no Fies, especialmente a Lei $n^{\circ} 12.513 / 11^{53}[\ldots]$ " (p. 39). Vale destacar que esse Programa passou por duas alterações significativas nos últimos cinco anos. A primeira, em 2010, impulsionou sobremaneira o número de contratos, a partir da redução da taxa de juros, da alteração no período de carência - tanto para o pagamento da dívida, como para sua amortização - e, além disso, permitiu o financiamento de $100 \%$ do valor da mensalidade. As inscrições podiam ser feitas a qualquer época do ano, contemplando, assim, a diversificação da modalidade de ingresso nas IES, como o vestibular agendado, por exemplo.

A outra modificação, já não tão boa para instituições e alunos, foi em atendimento ao ajuste fiscal implantado pelo governo em 2015. Para tanto, o programa teve sua taxa de juros elevada para 6,5\% a.a, ante os 3,4\% a.a, dos contratos que antecederam esse realinhamento nas regras do fundo. Essa mudança impactou fortemente o setor, com a queda brusca de contratos e o consequente desequilíbrio nas IES que tinham o Fies como principal fonte de recursos.

Para ratificar a predominância do setor privado, como continuidade da lógica que marcou os governos anteriores em relação à hegemonia das IES privadas, segue tabela com os números das instituições e matrículas, referente ao primeiro mandato da presidente Dilma (2011-2014), segundo dependência administrativa.

\footnotetext{
53 A referida Lei incluiu a possibilidade de financiamento a estudantes da educação profissional e tecnológica, em caráter individual ou coletivo, através de empresas. (LIMA, 2015, p. 39)
} 
Tabela 4 - Número de instituições, matrículas e vagas, segundo dependência administrativa - 2011 e 2014

\begin{tabular}{|c|c|c|c|c|}
\hline \multirow{2}{*}{ Ano } & \multicolumn{2}{|c|}{ Instituições } & \multicolumn{2}{|c|}{ Matrículas } \\
\hline & \multicolumn{2}{|c|}{2011} & \multicolumn{2}{|c|}{2014} \\
\hline Total & 2.365 & 2.368 & 6.739 .689 & 7.828 .013 \\
\hline Públicas & 284 & $298^{54}$ & 1.773 .315 & 1.961 .002 \\
\hline Privadas & 2.081 & 2.070 & 4.966 .374 & 5.867 .011 \\
\hline
\end{tabular}

Fontes: Sinopse da educação superior 2014 (INEP, 2016) e Resumo Técnico 2013 (INEP, 2015). Elaboração própria.

Ressalta-se que apesar da hegemonia do setor privado, percebeu-se uma inflexão, indicando redução do setor em relação ao número de instituições. Na direção contrária, as instituições públicas aumentaram de 284, em 2011, para 298 em 2014. No entanto, o mesmo não aconteceu com as matrículas que mantiveram o crescimento no setor privado, com um aumento de 1,26\%. Em 2011 as matrículas do setor privado correspondiam a 73,68\% do sistema e em 2014 esse valor subiu para 74,94\%.

Então, deve-se considerar os pontos de inflexão que marcaram os governos. Tanto no caso de Lula, quanto de Dilma, a expansão da oferta de educação superior também se deu por meio da criação de novas universidades federais, assim como de Institutos Federais de Educação Tecnológica - IFET, no âmbito do setor público.

Além disso, as políticas afirmativas contribuíram para aumentar a abrangência e diversificação do público, com acesso à educação superior, como as cotas para negros, indígenas e egressos das escolas públicas. Para Ferreira (2012),

[...] as políticas para a educação superior do governo Lula e Dilma assumiram também a perspectiva da equidade social articulada com a concepção de desenvolvimento econômico, da capacitação de mão de obra e da elevação da empregabilidade da população, principalmente quando faz a opção da construção de campi de instituições federais de educação superior no país. As políticas de ações compensatórias também ganharam destaque com os programas do ProUni e da Universidade Aberta do Brasil. (p. 469).

Outras ações foram representativas na direção de promover a democratização do acesso à educação superior no país. Sob a ótica da qualidade e permanência do estudante de graduação e a partir da necessidade de contribuir para que o aluno comece e termine seu

\footnotetext{
${ }^{54}$ Nesse total estão incluídas as federais, estaduais e municipais, localizadas nas capitais e no interior.
} 
curso, políticas de assistência estudantil foram criadas e fortalecidas, tanto no âmbito do setor público, quanto no do setor privado. O Programa Nacional de Assistência Estudantil PNAES foi instituído pelo Decreto $\mathrm{n}^{\mathrm{o}}$ 7.234, de 19 de julho de 2010, direcionados aos alunos carentes que estudam na educação superior pública federal. Para o setor privado, especificamente aos alunos do ProUni, a bolsa permanência, instituída pela Lei $\mathrm{n}^{\circ} 11.180$, de 23 de fevereiro de 2005, foi mantida.

A política de educação superior de Dilma Rousseff, a partir das metas definidas pelo Plano Nacional de Educação de 2014/2024, instituído pela Lei no 13.005 , de 25 de junho de 2014 corrobora a tendência privatista, segundo Lima (2015). Para a autora,

[...] em relação à Educação Superior, as metas 12,13 e 14 que tratam, respectivamente, da elevação da taxa de matrícula neste nível de ensino ( sic), da qualificação do corpo docente e da elevação do número de matrículas na pós-graduação stricto sensu (mestrado e doutorado). As estratégias para alcançar as metas do PNE estão relacionadas com as metas de expansão e reestruturação político-pedagógica do Reuni; a expansão do Fies, para a graduação e pós-graduação stricto sensu, inclusive a distância, o aperfeiçoamento do Sistema Nacional de Avaliação da Educação Superior (Sinaes); e a ampliação do Ensino a Distância/EAD através da Universidade Aberta do Brasil/UAB. (p. 40).

A Meta 20, que trata do investimento público em educação, a partir do aumento do PIB, cujo índice é de $10 \%$ ao final de 10 anos, a autora destaca que o Plano privilegia o setor privado ao prever, nesse valor, os gastos com o ProUni e o Fies. Sobre o assunto, Santos e Ferreira (2015) destacam que "um dos maiores embates no decorrer da tramitação do projeto de lei do PNE no congresso foi em relação ao Percentual do Produto Interno Bruto (PIB) que seria investido na educação [...]” (p. 59). A disputa girava em torno da exclusividade do investimento, pois os representantes do setor público não concordavam em dividir com o setor privado tais recursos.

Com a publicação das metas e estratégias definidas pelo novo PNE, constatou-se que os desafios são pujantes em relação à expansão, democratização e equidade do acesso à educação superior no país. Isso significa que, para além das disputas entre setores público e privado, ações que alcancem cada vez mais jovens aos bancos escolares, em geral, e universitários, em particular, fazem-se urgentes. Nesse sentido, o ProUni contribui com esse fenômeno, na visão da autora desta pesquisa.

Como toda política pública, o Programa Universidade para Todos deve ser acompanhado sistematicamente, com avaliações que permitam identificar irregularidades, desajustes e contradições. Afinal, o setor privado é um parceiro importante para a oferta de 
educação superior; não há como prescindir de seu papel. No entanto, o setor público deve contar com políticas que o empodere e o transforme no verdadeiro protagonista da oferta de educação, por ser o locus que oferece formação mais ampla, voltada não só ao mercado de trabalho, mas também à formação cidadã-humanística. No entanto, com o tamanho da participação do setor privado nessa relação, é necessário o acompanhamento sistemático da qualidade na oferta, pois, mais do que preocupar-se com a lógica expansionista, faz-se necessário primar pelo tipo de expansão que está sendo realizada. E, se esse fenômeno está promovendo, de fato, a democratização do acesso à educação superior, considerando os desafios presentes nesse nível educacional.

No próximo capítulo foi feita uma análise mais detalhada do ProUni, a partir das categorias escolhidas para abordar o fenômeno da democratização do acesso à educação, quais sejam: democratização, expansão e equidade. A democratização será vista sob diferentes abordagens. Há o entendimento de que democratizar é simplesmente ampliar o acesso com criação de vagas e expansão das matrículas. Contudo, a discussão vai para além disso. Autores como Nogueira (2008), Dias Sobrinho (2010b; 2013), Gomes e Moraes (2012) e Silva (2012) são alguns dos que destacam outras dimensões para o movimento aqui pesquisado, à luz do Programa Universidade para Todos.

Como esta pesquisa tem o objetivo de analisar a capacidade do ProUni em promover a democratização do acesso à educação superior, considerou-se importante trabalhar o tema, lançando um olhar dialético na direção dessas categorias, a fim de que se perceba as contradições inerentes à política. Como parte de uma totalidade, o ProUni integra o contexto da educação superior do país e deve ser analisado como uma política essencialmente contraditória e que desperta avaliações variadas acerca de seu alcance.

Nesse sentido, entender minimamente suas contradições, as dimensões que cercam suas ações, assim como os objetivos que a política atinge, é necessário para que a discussão se torne menos ideologizada. Os impactos do Programa precisam ser avaliados a partir do que é percebido junto à sociedade. Sendo assim, o próximo capítulo se propõe a realizar esse exercício de desnudar o caráter unicamente político das críticas sobre o ProUni, objetivando seus resultados. 


\section{CAPÍtULO 2 - PROGRAMA UNIVERSIDADE PARA TODOS - PROUNI: DEMOCRATIZAÇÃO DO ACESSO OU PRIVATIZAÇÃO DA OFERTA?}

Este capítulo trata do Programa Universidade para todos - ProUni e da proposta de democratização do acesso, prevista na lei que o instituiu. Os conceitos que envolveram o tema, como massificação, democratização e equidade, foram trazidos de forma a contribuir com o debate. Além disso, o Programa foi analisado à luz do novo Plano Nacional de Educação 2014/2024 e das metas estabelecidas para o próximo decênio, dentre elas, o aumento da taxa de escolaridade no âmbito da educação superior, levando em conta a dimensão da qualidade.

Como essa pesquisa aborda o ProUni e a democratização do acesso a partir de uma instituição privada do Distrito Federal, a última parte desse capítulo abordou a expansão desse nível educacional na região, com o objetivo de mostrar como se deu esse movimento e de que forma as instituições privadas, seguindo a lógica nacional, se tornaram hegemônicas na oferta dos cursos de graduação.

\subsection{Democratização do acesso à educação superior: um fenômeno a ser entendido}

Para tratar da expansão do acesso à educação superior, à luz da democratização do acesso, é necessário entender alguns conceitos sob a perspectiva do objeto proposto por essa pesquisa. O ProUni é uma política que promoveu o aumento de matrículas nas instituições privadas de educação superior e, para muitos, democratizou o ingresso de alunos em cursos de graduação.

No entanto, vários são os entendimentos sobre o que venha a ser, efetivamente, o processo de democratização do acesso à educação superior. Diferentes categorias são utilizadas para dimensionar o mesmo fenômeno, complementarmente. Nesse sentido, é necessário compreender qual foi o caráter utilizado para explicar os desdobramentos do ProUni, na dimensão aqui proposta.

Nesse sentido, cabe a pergunta: no que diz respeito ao acesso à educação superior, as políticas implementadas no governo Lula promoveram, afinal, uma expansão relacionada à ampliação ou à democratização? Para tentar responder, é necessário, em primeiro lugar, explicar esses conceitos. Em linhas gerais, ampliar, significa criar vagas. Sobre democratizar o acesso à educação superior, Nogueira (2008) entende que 
[...] o conceito de democratização do acesso ao ensino superior é mais abrangente e complexo, sendo possível identificar a existência de, pelo menos, três visões diferenciadas sobre o assunto.

Um primeiro conceito [...] associa a democratização do acesso à educação superior à simples ampliação de vagas. [...]

Um segundo conceito, [...] considera que a democratização do acesso à educação superior não se reduz a uma simples expansão da oferta de vagas. Essa democratização requer que camadas sociais não privilegiadas possam ingressar na universidade. Se os menos ricos ingressam na universidade, então se pode falar em democratização.

Um terceiro conceito [...] Parte do princípio de que a democratização requer que camadas sociais mais pobres tenham acesso à universidade, mas aponta um critério adicional. [...] $\mathrm{O}$ acesso à universidade se democratiza quando aumenta o acesso das camadas não privilegiadas e também quando crescem as chances de ingresso de negros. (p. 53- 54).

Portanto, a partir dos sentidos dados por Nogueira (2008) ao processo de democratização do acesso à educação superior e de algumas abordagens realizadas em diferentes momentos desta pesquisa, optou-se por considerar a conjugação dos três conceitos, por ela abordados, como a forma mais adequada para explicar esse fenômeno. Entenda-se, portanto, que democratizar é ampliar o acesso com inclusão de grupos historicamente alijados do ingresso à educação superior, entendido esses como sendo, principalmente, os pobres e os negros. Além deles, entenda-se como necessária a inclusão dos indígenas e das pessoas com limitações física e/ou cognitiva, nesse processo, como previsto na lei do ProUni.

Para avançar em relação aos conceitos apresentados, pode-se indicar a dimensão qualidade da oferta, como mais um ingrediente que contribui para a democratização do acesso ao nível superior. Há também a necessidade de consolidação dos meios de permanência do estudante na IES, o que seria um importante fator de ampliação do processo abordado, segundo atestou Dias Sobrinho (2010; 2013).

Nesta linha de raciocínio, vale destacar, ainda, o conceito de qualidade que estaria sendo reivindicado. Para esta pesquisa, considera-se educação de qualidade não aquela prevista pela concepção neoliberal, como forma de atribuir valor a quem possui melhores condições técnicas para lidar com a competitividade individual e empresarial (Teoria do Capital Humano), mas sim a que enxerga a educação como meio para conquistar a emancipação e a liberdade (visão marxista). A partir dessas diferentes visões, Dias Sobrinho (2010) considerou que

[...] em torno da hegemonia do conceito de qualidade ocorrem muitos conflitos e oposições entre os diferentes grupos de interesse. Cada grupo e, no limite, cada indivíduo prioriza em cada momento uma ou algumas características da qualidade educativa e não considera a sua complexidade 
semântica. De acordo com interesses relativos dos implicados em determinadas circunstâncias e admitindo sempre variações de ênfases, a qualidade estaria: na adequada capacitação para o trabalho e expansão de possibilidades de emprego; ou no aumento da competitividade por meio dos conhecimentos úteis, da inovação e do avanço da tecnologia; ou na elevação da formação cultural e política da população; ou no aprofundamento dos valores da democracia e no desenvolvimento da cidadania etc. Tudo isso e mais dificilmente esses elementos se articulam de forma harmoniosa em um todo compreensivo, visto que a educação é um fenômeno social e, então, o que se vai entender por qualidade educativa pertence a um campo complexo e permeado de contradições (p. 1228).

Nesse sentido, reitera-se que para esta pesquisa a democratização do acesso à educação superior deve ser compreendida como um processo de ampliação de vagas e de inclusão dos grupos social, econômica e historicamente marginalizados do processo de ingresso ao sistema de educação superior do país. Para tanto, o conceito de equidade como justiça social deve ser resgatado como um valor associado às políticas públicas elaboradas para o setor.

Ademais, considera-se necessário frisar a abordagem feita por Nogueira (2008), assim como por Dias Sobrinho (2010) sobre o impacto que a falta de qualidade na educação básica tem sob o assunto aqui estudado. Segundo esse autor,

[...] a melhoria do sistema de educação, em termos quantitativos e qualitativos, requerem investimentos públicos prioritariamente em, ao menos, duas áreas: é necessário empreender uma grande expansão da infraestrutura física das escolas de nível básico e, ao mesmo tempo, impulsionar vigorosamente a formação de mais e mais bem preparados professores (p.1232).

A qualidade da educação básica é, sem dúvida, uma questão de urgência nacional. Ao universalizar o acesso desse nível de educação, o governo não superou todos os desafios relacionados ao tema. Assim como há a necessidade de que os cursos de graduação sejam capazes de formar cidadãos cientes de seu papel na sociedade, em todas as suas dimensões, a formação básica é a responsável pelo alicerce intelectual do indivíduo. Nesse sentido, as questões que envolvem a democratização do acesso à educação superior levam a outra discussão, qual seja, a do acesso à educação básica de qualidade.

Além desse debate, a adoção de políticas afirmativas compõe outro eixo gerador de polêmicas que, como tal, precisa ser problematizado. De acordo com Nogueira (2008), aos que são contra as políticas de cotas, a defesa está voltada à qualidade da educação básica 
como fator homogeneizador de ingresso à educação superior. Já aos que defendem as ações afirmativas, a correção histórica das profundas desigualdades está no cerne da questão.

Seguindo a opção de dialogar com os sujeitos entrevistados em virtude desta pesquisa, considerou-se relevante descrever, ao longo do trabalho, algumas falas de professores, coordenadores de cursos, que entendem a oferta de educação básica de qualidade como sendo a solução para a superação das iniquidades sociais. Tais pensamentos, alinham-se aos mesmos princípios de quem considera que as ações afirmativas, traduzidas em cotas, são medidas equivocadas, pois, segundo seus defensores, essas políticas não contribuem para a democratização do acesso à educação superior.

Quando perguntado sobre a questão da promoção da equidade nas políticas de democratização do acesso à educação superior, o entrevistado representante da instituição pesquisada, respondeu que

[...] [se houver] uma educação de qualidade básica, ele vai ter acesso pra concorrer igualmente [...] não vejo diferença onde se prove cientificamente que o mesmo, se ele for pra uma escola básica de qualidade, um branco e um preto forem pra uma escola básica de qualidade, se eles tiverem a mesma condição de acesso, terão oportunidades desiguais [...] (GI1, informação verbal).

Em relação à mesma questão, o entrevistado, também da IES, abordou a educação básica como principal vetor de igualdade de condições. Em sua opinião, “o Brasil deveria fazer um ensino de qualidade, fundamental, um ensino médio, na educação básica. É muito importante isso pra que esses meninos tenham um crescimento melhor" (GI2, informação verbal). Nessa mesma linha, e respondendo à mesma pergunta, outro representante da instituição de educação superior, disse que

[...] o problema todo não é o problema do gênero, da raça, isso ou aquilo outro. O problema todo é a qualidade da educação, do ensino fundamental e do ensino médio [...] se a gente tiver um ensino médio de qualidade, a gente vai começar aí, definitivamente a equidade lá no ensino fundamental, ensino médio, ensino de qualidade [...] eu estudei em uma época em uma escola pública que alunos das instituições privadas concorriam para a escola pública, muitas vezes, [...] pela qualidade do ensino da escola pública [...] (GI3, informação verbal).

Outro entrevistado da IES, ao ser questionado sobre o alcance da expansão da educação superior em relação às pessoas mais desprovidas economicamente, também 
destacou a deficiência da educação básica como um dos problemas a ser enfrentado, para que esse alcance seja, efetivamente, realizado. Para ele,

[...] os mais desprovidos, eles não alcançaram ainda, porque primeiro tem uma questão da educação básica que vem com muita desvantagem, então o governo ainda precisa muito pensar na educação básica, e tem muita gente que ainda não tem ensino médio [...] o problema tá lá na raiz, está lá no ensino básico. Então, o governo precisa primeiro investir no ensino básico pra tirar essas pessoas de uma situação de miséria, pra depois dar acesso ao ensino superior. Eu acho que primeiro começa por aí. (G4, informação verbal).

Pode-se dizer que o governo Lula intensificou esse debate, dentro e fora das universidades, ao criar o Sistema Especial de Reserva de Vagas para estudantes egressos de escolas públicas, em especial negros e indígenas ${ }^{55}$. E, mesmo algumas universidades já tendo implantado programas nesse sentido, o governo federal teve papel importante no fomento ao assunto (NOGUEIRA, 2008).

Considerando outras categorias de análise, dentre elas, o conceito de massificação, entendida como privatização do acesso, Gomes e Moraes (2012) explicam que nem sempre ampliar vaga garante a entrada dos jovens a esse nível de educação e ressaltam que,

[...] muito embora o termo "massificação" tenha se tornado de uso corrente na literatura da área, ele tem sido usado frequentemente como sinônimo de "privatização". Consideramos que privatização e massificação não se referem ao mesmo processo político-social. O caso brasileiro nos ajuda a entender tais processos, porque a emergência do sistema de massa ocorre em grande parte por meio da privatização da oferta de vagas na ES. Entretanto, o sistema de massa ou o processo que o constitui, a massificação, pode ser analisado tomando como referência a democratização do acesso. [...] o sistema de massa tem sido tratado como um sistema de ensino massificado, portanto de baixa qualidade. Essa parece ser uma tendência real no caso brasileiro, particularmente no setor privado (p.186).

Partindo dessa mesma abordagem, ao retratar o período militar brasileiro (19641985) e o aumento das vagas nas instituições privadas de educação superior, naquele momento, Oliveira (2013) ressaltou a questão da qualidade como ponto central, ao considerar que a simples ampliação de vagas, promovendo a massificação do acesso, pode ser chamada

\footnotetext{
${ }^{55}$ O Projeto de Lei $\mathrm{n}^{\mathrm{o}} 3627$ (BRASIL, 2004), que instituía o Sistema, foi enviado ao Congresso Nacional em 2004. Apenas em agosto de 2012 virou Lei ${ }^{\circ}$ 12.711/12 (BRASIL, 2012a), regulamentada pelo Decreto $n^{\circ}$ 7.824 (BRASIL, 2012b) e acompanhado pela Portaria Normativa 18/2012 (BRASIL, 2012c) do MEC, que estabelece os conceitos básicos da lei, modalidades e condições para sua aplicação.
} 
de "pseudodemocratização [...], na medida em que procura universalizar, ou seja, tornar acessível às massas um ensino qualquer” (p. 286).

No entanto, para avançar sobre as diferentes dimensões acerca do objeto pesquisado, é preciso conhecer o tamanho do problema que está sendo abordado. Significa dizer que, ao analisar o fenômeno da democratização do acesso à educação superior, fez-se importante ter a dimensão do quadro que se impõe acerca da realidade educacional do país.

A desigualdade no acesso à educação está presente em todos os níveis. Isso evidencia os impactos causados pela injustiça social, que encontra lastro na omissão do Estado e na incompetência desse em elaborar políticas públicas que promovam a cidadania com equidade. Segundo Silva (2012),

[...] a equidade tem se apresentado como princípio de justificação das políticas públicas voltadas para a formação da cidadania [...] seja no que se refere aos recursos materiais mínimos que são considerados necessários para se ter uma vida cidadã e que caberia ao Estado proporcionar a indivíduos, famílias ou grupos específicos destituídos dos meios básicos de subsistência. (p. 79).

Os dados estatísticos, fartamente disponíveis, evidenciam o quanto nossa sociedade é desigual e, portanto, carente de políticas que promovam a redução dos profundos abismos existentes entre classes, raças e demais grupos sociais. O censo da educação superior de 2012 (INEP, 2014) informava que a taxa de escolarização segundo o quintil de renda tinha uma diferença de mais de 10 vezes entre os $20 \%$ mais ricos, para os $20 \%$ mais pobres, sendo o percentual de escolarização de 47,7\% e 3,9\%, respectivamente. A taxa bruta de escolarização da educação superior, de pessoas fora da faixa etária de 18 a 24 anos era de $28,7 \%$ e a taxa líquida, cujo percentual de pessoas de 18 a 24 anos que frequentam cursos de graduação em relação à população da mesma faixa etária, era de $15,1 \%$, segundo o mesmo levantamento.

As assimetrias se repetem quando se considera critérios de renda, raça, origem escolar, e escolaridade dos pais. Os brancos que moram na cidade, economicamente mais favorecidos, egressos de escola particular e com pais bem formados, compõem o grupo com maiores possibilidades de ingresso e permanência numa instituição de educação superior, seja pública ou privada. Além disso, os cursos mais concorridos e de mais alto custo também são ocupados, majoritariamente, por esses estudantes, conforme destacou Ristoff (2014).

Em relação aos grupos étnico-raciais, o quadro de desigualdade é ainda mais desolador. Com uma população fortemente heterogênea, essa característica não é refletida no cenário da educação superior. A hegemonia branca prevalece no campus da universidade 
brasileira, incluindo nas IES privadas. Essa é uma das conclusões a que chega Ristoff (2014) ao traçar o novo perfil dos estudantes nas instituições de educação superior brasileiras. Ele utilizou as respostas dos graduandos que responderam ao questionário socioeconômico do Exame Nacional de Desempenho do Estudante - Enade dos três primeiros ciclos completos do referido exame. Apesar dos avanços em relação à democratização do acesso à educação superior, o trabalho de Ristoff (2014) identificou que a paridade entre os diferentes grupos sociais ainda está longe de acontecer.

Ao fazer o cruzamento dos dados da Pnad 2014 (IBGE, 2015) com o Censo da Educação Superior de 2014 (INEP, 2016) é possível perceber essas distorções. Os negros (soma dos pretos e pardos, segundo denominação utilizada pelo IBGE) representam 53,6\% da população total, estimada pela pesquisa. O mesmo estrato social é representado nas IES, por apenas $22,14 \%$. Entre os brancos, $31,05 \%$ estão matriculados em uma graduação e sua representação populacional é de 45,5. Constata-se, portanto, que apesar dos negros serem a maioria da população brasileira, são os brancos que têm maior número de matrículas nas instituições de educação superior. Quanto aos amarelos e indígenas evidencia-se que eles são os únicos que fazem parte de um grupo que supera, percentualmente, a presença na educação superior em relação à sua representação na sociedade brasileira. Ainda assim, eles fazem parte de um grupo de quase dois milhões de pessoas que devem contar com políticas públicas que os alcancem, como fica mais claro, na tabela 5, a seguir.

Tabela 5 - Distribuição percentual da população brasileira e das matrículas na educação superior por cor ou raça - 2014

\begin{tabular}{|c|c|c|c|c|}
\hline $\begin{array}{c}\text { População } \\
\text { brasileira } \\
\text { (estimada) }\end{array}$ & Em milhões & $\%$ & $\begin{array}{c}\text { Matrículas na } \\
\text { Educação Superior }\end{array}$ & $\%$ \\
\hline Total & 203,2 & 100 & 7.828 .013 & 100 \\
\hline Branca & 92,4 & 45,5 & 2.431 .006 & 31,05 \\
\hline Parda & 91,4 & 45 & 1.395 .529 & 17,82 \\
\hline Preta & 17,4 & 8,6 & 338.537 & 4,32 \\
\hline $\begin{array}{c}\text { Indígena ou } \\
\text { amarela }\end{array}$ & 1,8 & 0,9 & 123.673 & 1,57 \\
\hline $\begin{array}{c}\text { Não dispõe de } \\
\text { informação } \\
\text { e/ou não } \\
\text { declarados }\end{array}$ & - & - & 3.539 .268 & 45,21 \\
\hline
\end{tabular}

Fonte: IBGE (2015), dados PNAD 2014; INEP (2016), dados Censo da Educação Superior 2014. Elaboração própria. 
Seguindo a mesma lógica da hegemonia branca presente nas IES, vale destacar outro fenômeno. Ristoff (2014) identificou em seu trabalho que os cursos de alta demanda, como medicina e engenharia são, majoritariamente, ocupados por brancos; e que cursos de licenciatura, como história, são frequentados, em sua maioria, por pretos. Essa constatação corrobora com a tese de que o acesso à educação no Brasil continua elitista, em muitos aspectos, como será visto mais adiante.

Esses números ratificavam os desafios presentes na sociedade brasileira em relação à democratização do acesso à educação, com equidade. Significa dizer que ainda há muito que fazer em relação à justiça social, cujo alcance deve ser os grupos historicamente alijados das oportunidades educacionais. Sobre o assunto, destacam-se os dados que ilustram bem o caráter elitista presente na educação superior do país. Ristoff (2014) identificou nos três ciclos do Enade, dos cursos pesquisados, a supremacia de brancos e de maior renda familiar no curso de medicina. A título de ilustração, no $3^{\circ}$ ciclo, o percentual de estudantes com renda familiar de mais de 10 salários mínimos cursando a referida graduação foi de $44 \%$. Entre os brancos o índice é de $74 \%$ e a de pretos, no mesmo período, de $2 \%$.

Para ilustrar o quanto o perfil econômico diferencia os grupos, em relação ao tipo de instituição frequentada, seguem dados referentes aos estudantes que estão nas redes pública e privada e que correspondem aos $20,0 \%$ mais pobres e aos $20,0 \%$ mais ricos da população.

Gráfico 8: Estudantes da rede pública e particular com distribuição percentual por quintos de renda per capita - Ensino Fundamental, Ensino Médio e Educação Superior (Brasil, 2013)

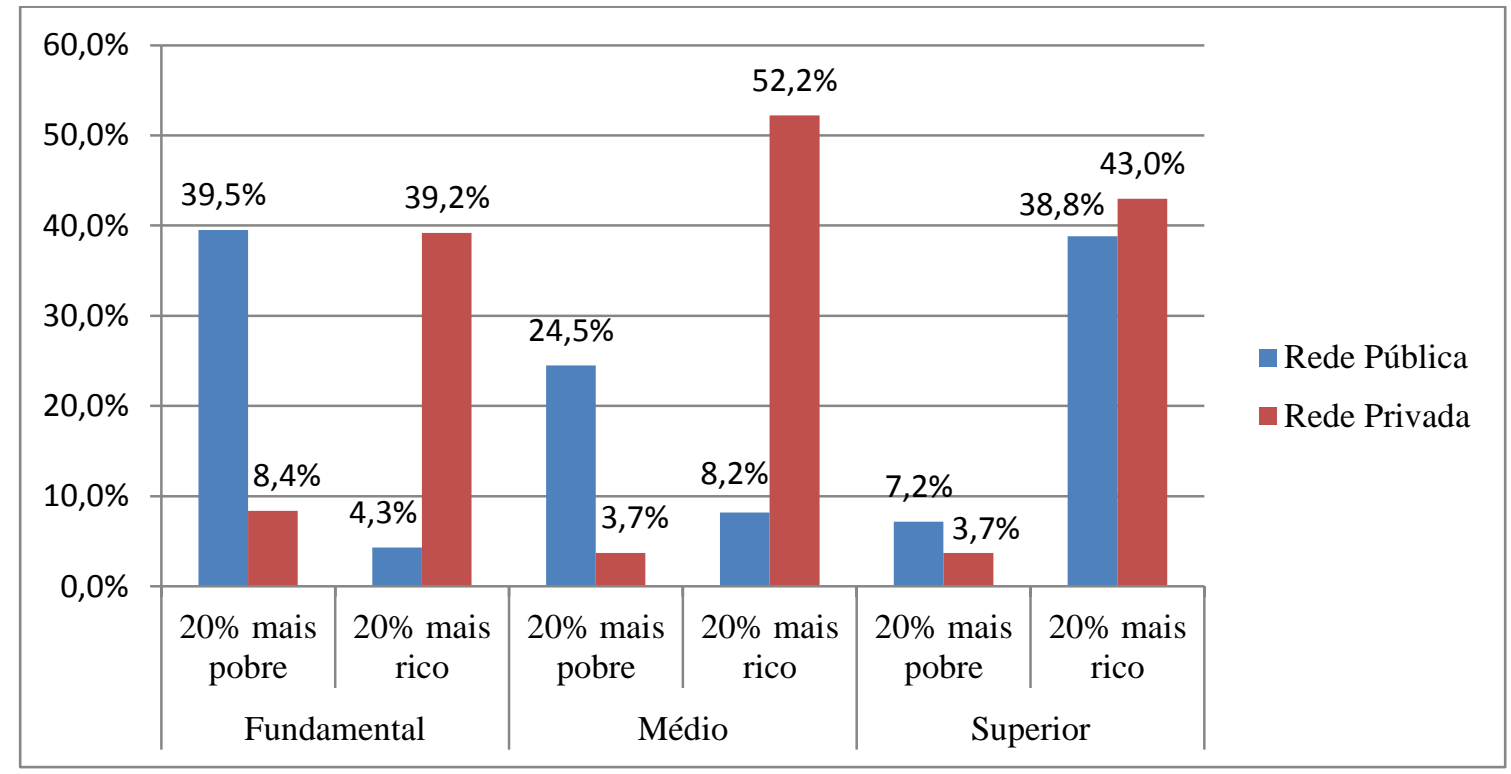

Fonte: IBGE (2015). Dados: PNAD 2013. Elaboração própria 
O dado mais revelador diz respeito, sem dúvida, aos estudantes da educação superior. Tanto o setor público, quanto o privado são ocupados, em sua maioria, pelos 20,0\% mais ricos da população, $43,0 \%$ na rede privada e $38,8 \%$ na pública. A parcela mais pobre tem $7,2 \%$ de estudantes nas instituições de educação superior públicas e outros 3,7\% nas instituições privadas. Quando se compara o percentual de ocupação do setor público pelos mais ricos nos níveis fundamental e médio, depara-se com taxas abaixo dos 10,0\%. O ensino médio é representado por $8,2 \%$ de estudantes e o fundamental, por 4,3\%. Aos mais pobres, esses níveis de ensino tem o setor público como a principal opção - 39,5\% (fundamental) e 24,5\% (médio). Esses dados ratificam a percepção de que a democratização do acesso à educação, desde a básica até a superior passa pela necessidade de redução das assimetrias entre os mais ricos e os mais pobres. E, no que diz respeito à educação superior, foco deste trabalho, a certeza do quanto ainda é um campo para os mais privilegiados economicamente.

Dados do próprio governo federal ${ }^{56}$ ratificam o déficit educacional na sociedade brasileira e a não superação desse, desvelando o caráter elitista da formação escolar da população. Apesar das políticas criadas ao longo dos últimos vinte anos, que minimizaram as assimetrias, a perversa herança da desigualdade social ainda se revela no cenário da educação brasileira. No entanto, como este trabalho tem por foco um programa de acesso à educação superior, tornou-se mister resgatar o recente panorama desse nível educacional.

Para ilustrar a discrepância existente na oferta de vagas de nível superior entre os setores público e privado, destaca-se que, em 2014, 87,41\% das IES eram privadas e 12,5\% públicas, incluindo aí as federais, estaduais e municipais, segundo o Censo da Educação Superior $^{57}$. Em relação às matrículas, no mesmo ano foram totalizadas 7.828.013, sendo 1.961.002 nas públicas e 5.587.011 nas privadas, neste último caso representando 74,94\% do total de matrículas da educação superior em 2014 (INEP, 2016).

É importante destacar, porém, que avanços foram realizados, sobretudo a partir do governo de Luiz Inácio Lula da Silva (2003-2010), com o objetivo de reduzir os abismos e

\footnotetext{
${ }^{56}$ Os censos da educação básica e superior (INEP), os dados educacionais da Pnad e do censo demográfico (IBGE), além de documentos como: "As desigualdades na Escolarização no Brasil, Relatório de Observação $\mathrm{n}^{\circ}$ 5" (BRASIL, 2014), realizado pelo Conselho de Desenvolvimento Econômico e Social - CDES, da Presidência da República - PR, dão conta de grande parte do cenário educacional brasileiro e de suas fragilidades.

${ }^{57}$ Os censos da educação superior são realizados pelo Instituto Nacional de Estudos e Pesquisas Educacionais Anísio Teixeira - INEP, autarquia vinculada ao Ministério da Educação, com o objetivo de fornecer informações detalhadas sobre o tema. Esses levantamentos são feitos anualmente e reúnem "informações sobre as instituições de ensino superior, seus cursos de graduação presencial ou à distância, cursos sequenciais, vagas oferecidas, inscrições, matrículas, ingressantes e concluintes” (INEP, 2016).
} 
iniquidades relacionados à possibilidade de ingresso em uma graduação. O ProUni é uma política que vai nessa direção, mesmo diante dos debates acalorados acerca de seu modelo e proposta, os quais revelam suas contradições, presentes em toda e qualquer política pública.

A partir de dados que confirmam o aumento do acesso à educação superior, nos últimos anos e, considerando que houve expansão, não só do setor privado, mas também do público, pode-se dizer que os índices melhoraram, não obstante, continuam bem distantes daqueles apresentados por países desenvolvidos, e até mesmo pelos seus vizinhos do continente. Um estudo comparativo, publicado em 2015, pela Organização para a Cooperação e Desenvolvimento Econômico - $\mathrm{OCDE}^{58}$, mostrou que o Brasil obteve uma média de $14 \%$ para a população de 25 a 64 anos que concluem a educação superior, a qual encontra-se bem abaixo dos $34 \%$ da população dos países participantes que seguem a mesma trajetória. O cenário brasileiro não se mostrou mais promissor, nem mesmo em relação aos países da América Latina: Chile (21\%), Colômbia (22\%), Costa Rica (18\%) e México (19\%) (OECD, 2015).

No entanto, ampliar vagas não significa democratizar o espaço universitário. À ampliação, soma-se o desafio da democratização do acesso com equidade, entendida por Dias Sobrinho (2010) como oferta de educação com qualidade, caso contrário, mantêm-se as desigualdades, ao continuar privilegiando uma elite, com educação diferenciada. Segundo o autor,

[...] do ponto de vista da equidade, uma sociedade que não atende as necessidades educacionais, em quantidade e qualidade, de toda a população é injusta e democraticamente pouco desenvolvida. A educação de elite e para uma elite cumpre seu papel com relação ao mercado global e à preservação das classes ricas e poderosas, mas não contribui para a edificação de uma nação justa, ética e culturalmente evoluída. (p. 124).

Ao analisar as opções relacionadas à política de educação superior no governo Lula, embora a reforma não tenha saído em sua inteireza, constata-se que houve grandes ações traduzidas em políticas públicas. Conforme já citado, tais ações promoveram uma ampliação no acesso à educação superior por meio de bolsas, cotas, vagas nas universidades públicas, assim como por meio da criação da Universidade Aberta do Brasil - UAB, impulsionando,

\footnotetext{
58 A OCDE é uma organização internacional que congrega 35 países. Dentre suas ações está a elaboração de estudos comparativos sobre política econômica, além da coordenação de políticas direcionadas aos seus membros e a outros países. Esses dados foram descritos na publicação "Education at a Glance: OECD Indicators", considerada " a principal fonte de informações relevantes e precisas sobre o estado da educação ao redor do mundo. [...] oferece dados sobre a estrutura, o financiamento e o desempenho de sistemas educacionais de 34 países membros [...]de alguns países parceiros e do G20" (OECD, 2016).
} 
sobremaneira, a educação a distância - EaD no país. Nogueira (2008) esclareceu que a ampliação do acesso "pode ser compreendida conceitualmente como a criação de novas vagas nas instituições que ofertam esse nível de ensino, tanto no âmbito do setor público quanto privado" (p.50).

Vale lembrar que a EaD, por meio da TIC - Tecnologia de Informação e Comunicação é um mercado bastante promissor e não menos visado pelo setor privado. Segundo Otranto (2006), “o mercado da educação a distância no Brasil vem sendo cortejado há algum tempo por vários países que pretendem explorá-lo" (p.12). Além disso, pode-se dizer que essa modalidade de ensino, para os organismos internacionais, é um bom caminho para a formação rápida, atendendo aos ditames do mercado, tanto na oferta do ensino, quanto na formação de mão-de-obra.

Cabe observar ainda que a $\mathrm{EaD}$ e as tecnologias de informação e comunicação são traduzidas como oportunidade de inserção no mercado de trabalho e no mundo tecnológico, diminuindo, segundo o discurso oficial, as diferenças entre as pessoas no que diz respeito a esse tipo de conhecimento. No entanto, para Lima (2007),

[...] não pode haver homogeneização do espaço, porque a acumulação do capital ocorre em ritmos desiguais de tempo e realiza-se por meio das profundas desigualdades de concentração da produção e do consumo da estrutura técnico-produtiva em determinadas regiões e países, em detrimento de outras áreas do espaço mundial. [...] As inovações tecnológicas não alcançam todos os países e regiões, apenas aqueles de interesse do capital. [...] São, portanto, a crise estrutural do capital e a concorrência intercapitalista que determinam o desenvolvimento desse sistema técnicoinformacional, cuja difusão será realizada [...] pelos organismos internacionais do capital, especialmente BM, Unesco e OMC. (p. 184).

Vê-se que, mais uma vez, os organismos multilaterais estão presentes nas políticas do governo por meio de orientações e recomendações. A EaD é um bom exemplo de como o Estado assimilou e aceitou o ideário desses. Sabe-se claro, como já foi dito, que essa iniciativa está intimamente ligada ao modelo estatal, de viés neoliberal, o qual contraria, por exemplo, o discurso de campanha do ex presidente Lula e sua histórica trajetória voltada aos segmentos sociais do país, ainda que o mesmo tenha tomado medidas mais populares que seu antecessor - FHC.

A ampliação do Fundo de Financiamento Estudantil - Fies também aumentou as chances de que alunos de baixa renda ingressassem nas instituições privadas, por meio de empréstimos a serem pagos após a formação. No entanto, em que pese o fato das instituições privadas continuarem contando com políticas que fortalecem seu segmento, mantendo o 
protagonismo na oferta de educação superior no país, a discussão que se faz no momento é o quanto esse setor contribuiu com a expansão do sistema e, mais do que isso, o quanto foi importante para oferecer oportunidades aos jovens e, também, aos não tão jovens, de ingressar em um curso de nível superior por meio do ProUni. Além disso, vale refletir sobre as possibilidades de que dispõe o Estado, para fomentar esse processo, considerando a necessidade de reduzir as profundas assimetrias presentes na sociedade brasileira.

O Programa Universidade para Todos promoveu o ingresso de 1,49 milhão de estudantes à educação superior no período de 2005 a 2014 (bolsas parciais e integrais), segundo dados do Ministério da Educação (MEC, 2015). Ao comparar o número total de matrículas em todo o Brasil entre os setores público e privado (7.828.013) só no ano de 2014, segundo Censo da Educação Superior de 2014 (INEP, 2016), há de se questionar em que medida os números do ProUni representam de fato, um passo na direção da democratização do acesso à educação superior. Esta pesquisa propôs-se a abordar o tema, ampliando seu escopo. Significa dizer que, a partir de dimensões como expansão, ampliação, equidade, qualidade e permanência, pretendeu-se analisar a política em questão como proposta para minimizar os déficits educacionais e contribuir com a redução das assimetrias socioeconômicas presentes na sociedade brasileira.

Nesse sentido, no próximo item, o Programa foi abordado com mais detalhes, para que, assim, fosse possível conhecê-lo melhor. Além disso, pretendeu-se ainda, depreender análises que indicassem respostas ao objetivo geral desta pesquisa, que é o de identificar em que medida essa política promove a democratização do acesso à educação superior.

\subsection{Programa Universidade para Todos: uma política que democratiza?}

O ProUni é uma política que tem como objetivo beneficiar estudantes de baixa renda que estudaram em escola pública ou em escola particular com bolsa integral, além de professores da rede pública de ensino, desde que, à formação do magistério da educação básica. O Programa também reserva cotas para estudantes negros, indígenas e pessoas com deficiência. (BRASIL, 2005).

Sobre o acesso à educação superior, pode-se dizer que o ProUni contribuiu para sua ampliação, com a crescente oferta de bolsas, tanto parciais como integrais, de acordo com os 
critérios previstos na Lei nº 11.096 de 13 de janeiro de 2005, que o criou após a conversão da Medida Provisória $213^{59}$, de 10 de setembro de 2004. Assim trata o texto da lei:

Art. 1 Fica instituído, sob a gestão do Ministério da Educação, o Programa Universidade para Todos - PROUNI, destinado à concessão de bolsas de estudo integrais e bolsas de estudo parciais de $50 \%$ (cinqüenta por cento) ou de $25 \%$ (vinte e cinco por cento) para estudantes de cursos de graduação e seqüenciais de formação específica, em instituições privadas de ensino superior, com ou sem fins lucrativos.

$\S 1 \mathrm{~A}$ bolsa de estudo integral será concedida a brasileiros não portadores de diploma de curso superior, cuja renda familiar mensal per capita não exceda o valor de até 1 (um) salário-mínimo e 1/2 (meio).

$\S 2$ As bolsas de estudo parciais de $50 \%$ (cinquienta por cento) ou de $25 \%$ (vinte e cinco por cento), cujos critérios de distribuição serão definidos em regulamento pelo Ministério da Educação, serão concedidas a brasileiros não-portadores de diploma de curso superior, cuja renda familiar mensal per capita não exceda o valor de até 3 (três) salários-mínimos, mediante critérios definidos pelo Ministério da Educação.

§ 3 Para os efeitos dessa Lei, a bolsa de estudos refere-se à semestralidades ou anuidades escolares fixadas com base na Lei $n^{\circ} 9.870$, de 23 de novembro de 1999.

$\S 4$ Para os efeitos desta Lei, as bolsas de estudo parciais de 50\% (cinqüenta por cento) ou de $25 \%$ (vinte e cinco por cento) deverão ser concedidas, considerando-se todos os descontos regulares e de caráter coletivo oferecidos pela instituição, inclusive aqueles dados em virtude do pagamento pontual das mensalidades. (BRASIL, 2005).

Além dos critérios de elegibilidade, acima previstos, há de se destacar os demais passos para ser selecionado a uma bolsa do ProUni. Existem dois momentos em que é possível inscrever-se para o Programa. Num primeiro momento, o aluno precisa ter participado do último Exame Nacional do Ensino Médio - Enem ${ }^{60}$ e ter feito o mínimo de 450 pontos, além de não ter zerado a nota da redação. Em um segundo momento, o processo é destinado às vagas remanescentes, em que podem participar professor de educação básica, da rede pública de ensino que deseja cursar licenciatura ou que tenha participado do Enem, a partir da edição de 2010. Nesse caso, as notas obedecem à mesma lógica da pontuação mínima de 450 e da nota acima de zero na redação.

\footnotetext{
${ }^{59}$ A referida Medida Provisória foi assinada em setembro de 2004 instituindo o Programa Universidade para Todos. O governo optou por tal diploma legal para evitar demora na implementação da política, considerando o tempo que leva o debate e aprovação de uma lei no Congresso Nacional.

${ }^{60}$ O Exame Nacional do Ensino Médio - Enem foi criado em 1998, por meio da Portaria MEC no 438 de 28 de maio de 1998 com vistas a avaliar o desempenho dos alunos para, dentre outros objetivos, conferir parâmetro para auto-avaliação, criar referência nacional para os egressos de qualquer das modalidades do ensino médio; fornecer subsídios às diferentes modalidades de acesso à educação superior; constituir-se em modalidade de acesso a cursos profissionalizantes pós-médio (MEC, 1998). No entanto, ao longo dos anos, o exame passou por mudanças que ampliaram seu escopo e suas notas passaram a ser usadas em diversos processos seletivos, incluindo o ProUni.
} 
Em se tratando do aumento da oferta de vagas à educação superior, é preciso destacar que o Programa contribuiu para o atendimento parcial da meta estabelecida pelo Plano Nacional de Educação - PNE, instituído pela Lei n $n^{\circ}$ 10.172/01, de 09 de janeiro de 2001, que previa um índice de $30 \%$ de jovens entre 18 e 24 anos cursando a educação superior até o fim da vigência da Lei, a qual tinha duração de dez anos.

Pois bem, mesmo sabendo que nem todas as bolsas ofertadas são preenchidas, ainda assim, vale destacar quantas foram disponibilizadas entre 2013 e 2014, sendo esse, o ano em que iniciou a vigência do novo PNE. Em 2013 foram ofertadas 164.379 bolsas integrais e 87.995 parciais e em 2014 foram 205.237 da primeira modalidade e 101.489 da segunda (MEC, 2015d). Destaca-se, portanto, que foram ofertadas, de 2005 a 2013, 873.648 bolsas de $100 \%$. Quanto às parciais, que podem ser tanto de $50 \%$ quanto de $25 \%$, haviam sido ofertadas, nesse mesmo período, 400.017. Fazendo a soma do total de bolsas (duas modalidades), chega-se a um número considerável de 1.273.665 bolsas ofertadas em nove anos. (MEC, 2015a).

Vale ressaltar que instituições de educação superior de diferentes categorias administrativas puderam aderir ao Programa, sendo elas com fins lucrativos, sem fins lucrativos não beneficentes e as beneficentes de assistência social ${ }^{61}$. Considerando suas particularidades, todas contaram com a contrapartida da isenção de impostos e contribuições, conforme explicitado no art. $8^{\circ}$ da lei que criou o ProUni:

Art. $8^{\circ} \mathrm{A}$ instituição que aderir ao Prouni ficará isenta dos seguintes impostos e contribuições no período de vigência do termo de adesão: (Vide Lei $n^{\circ}$ 11.128, de 2005)

I - Imposto de Renda das Pessoas Jurídicas;

II - Contribuição Social sobre o Lucro Líquido, instituída pela Lei n ${ }^{\circ} 7.689$, de 15 de dezembro de 1988;

III - Contribuição Social para Financiamento da Seguridade Social, instituída pela Lei Complementar n 70, de 30 de dezembro de 1991; e

IV - Contribuição para o Programa de Integração Social, instituída pela Lei Complementar $\mathrm{n}^{\circ} 7$, de 7 de setembro de 1970. (BRASIL, 2005)

Sobre as instituições beneficentes, Santana (2009) destaca que "elas passam a não pagar, apenas a Contribuição Social para o Financiamento da Seguridade Social (COFINS) e a Contribuição para o Programa de Integração Social (PIS)" (p.31). Tendo em vista já serem isentas dos outros tributos, a autora ainda esclarece que essas instituições beneficentes são por

\footnotetext{
${ }^{61}$ Entidades beneficentes de assistência social são pessoas jurídicas de direito privado, sem fins lucrativos, reconhecidas como instituições que prestam serviços nas áreas de educação, assistência social ou saúde. No entanto, para que sejam reconhecidas com tal, é necessário certificado, concedido pelo governo federal, por meio do MEC e do MDS. (MEC, 2016).
} 
ela consideradas sem fins lucrativos, podendo ser, conforme classificação da LDBEN/1996, comunitárias, confessionais ou filantrópicas (SANTANA, 2009).

As instituições com fins lucrativos são as que mais ofertam bolsas - 56\%. As entidades beneficentes ofertam um total de $27 \%$ de bolsas e os $17 \%$ restantes ficam a cargo das instituições sem fins lucrativos não beneficentes.

É importante construir uma fotografia do Programa em termos de distribuição de bolsas, segundo os critérios estabelecidos pela Lei 11.096/2005, para que se possa identificar se os seus objetivos estão sendo alcançados, tais como a ampliação e a democratização do acesso à educação superior como promoção da equidade. Conforme dados do MEC, existem 686.189 bolsistas da raça branca e 759.239 negros (entendidos como a soma de pretos e pardos), sendo que apenas 188.340 são pretos. Quanto aos indígenas, o número é de 1.887 bolsistas (MEC, 2015).

Considerando o perfil de raça, vale destacar o estudo de Ristoff (2014), já comentado anteriormente, que utilizou o questionário socioeconômico do Exame Nacional de Desempenho dos Estudantes (Enade), para avaliar em que medida as diversas políticas de ampliação e democratização do acesso à educação superior, como o ProUni, o Fundo de Financiamento do Ensino Superior - FIES e a Lei de Cotas, dentre outros, estão alterando o perfil do estudante de graduação do campus brasileiro. Dentre as constatações relativas ao estudo, o autor destaca que

a) embora se observe uma diminuição do percentual de estudantes de cor branca e um pequeno aumento dos estudantes de cores preta e parda no período de 2004 a 2012, em média o campus brasileiro continua significativamente mais branco que a sociedade brasileira.

b) Em 16 cursos a representação percentual de pretos é igual ou superior aos percentuais na população brasileira. $\mathrm{O}$ mesmo não pode ser dito sobre os pardos. Com $43 \%$ de representação na sociedade brasileira, este grupo não possui um único curso de graduação em que sua representação seja igual ou superior à sua representação na sociedade.

c) O campus brasileiro como um todo ainda está longe de refletir a nova realidade populacional revelada pelo último Censo do IBGE, na qual, pela primeira vez, pretos e pardos formam o grupo majoritário da população brasileira, com $51 \%$, contra $48 \%$ de brancos. (p. 742).

Para corroborar com essas conclusões apresentadas pelo referido autor, destaca-se os dados disponibilizados pelo Sistema do ProUni - SisproUni: 45,8\% de bolsistas brancos, $38,2 \%$ pardos, $12,6 \%$ pretos e $0,1 \%$ de indígena (MEC, 2015). Entre os alunos com deficiência, temos uma representação bastante reduzida. Apenas 1\% dos bolsistas possuem algum tipo de deficiência (10.340 estudantes), quadro que demonstra a necessidade de 
conhecer o número total de deficientes no país para que se possa identificar se o Programa conseguiu atingir, proporcionalmente, esse grupo, inserindo-o na educação superior.

Como o foco dessa pesquisa restringiu-se a uma instituição de educação superior do Distrito Federal, foi importante conhecer o cenário dessa política na região centro-oeste e, especificamente, no DF, em termos de distribuição de bolsas a fim de, posteriormente, se analisar a política dentro da IES pesquisada.

Nesse sentido, vale atentar-se para a distribuição de bolsas por região e por unidade federativa. Ao analisar os dados, percebe-se que a região centro-oeste é a segunda com menor número de bolsistas, ficando atrás apenas da região norte. Com um total de 145.218 estudantes, aquela região tem $10 \%$ do total de bolsistas distribuídos pelo restante do país. E, quanto à unidade federativa, o Distrito Federal encontra-se em segundo lugar, na região, em número de bolsistas, com um total de 44.210, ficando atrás, apenas, do Estado de Goiás, com 46.353 beneficiários. (MEC, 2015).

Os dados estatísticos relacionados ao Programa revelam avanços, mas também continuidades, como a supremacia da região sudeste, com $50 \%$ de todos os bolsistas, que, em números absolutos, são 755.889 estudantes. Percebe-se, no entanto, que, apesar de tímido, houve avanço em relação ao ingresso de negros nas IES. Contudo, a discussão em torno da democratização do acesso com equidade deve contribuir para a ampliação desses avanços. $\mathrm{O}$ contexto universitário deve ser preenchido de maneira heterogênea, além de ser obrigação do Estado promover políticas públicas que atendam a todos e não apenas a uma camada da população.

É imprescindível que os governos se preocupem com os grupos que sempre estiveram à margem da sociedade e excluídos dos programas governamentais. As chamadas minorias não podem continuar ocupando um lugar de exclusão. Os negros, os índios, as pessoas com deficiência, os carentes devem ter seus direitos sociais garantidos. Afinal, esses cidadãos pagam impostos, assim como todos, e, portanto, precisam ter acesso a políticas que os inclua, como preveem os direitos e as garantias constitucionais.

Ao instituir o Programa, o governo Lula quis dar uma resposta a um anseio da sociedade, que, naquele momento, demandava ofertas de vagas na educação superior. Considerando que o governo deve estar atento ao que a sociedade demanda, em termos de políticas públicas, faz-se imperioso que suas ações não se pautem exclusivamente pela ideologia. Arruda (2011) salienta que 
[...] a fixação numa única forma de compreender as práticas sociais pode imprimir uma concepção ideológica, impedindo entender que uma política não se impõe e que a mesma pode ser redefinida a partir de novas práticas articulatórias em função das forças políticas presentes. (p. 506).

Alguns estudos discorrem, de maneira detalhada, sobre o processo de elaboração da Lei $\mathrm{n}^{\mathrm{o}}$ 11.096, de 13.01.2005, que instituiu o Programa, destacando todas as mudanças, sofridas, desde o Projeto de Lei, passando pela Medida Provisória, até chegar à versão definitiva da norma. Segundo Catani; Hey e Gilioli (2006), o governo cedeu à maioria das pressões feitas pelos representantes do setor privado.

O Programa previu que tanto as instituições com fins lucrativos, quanto aquelas sem fins lucrativos não beneficentes e as beneficentes de assistência social, deveriam reservar bolsas, tendo como contrapartida isenções fiscais. Nesse sentido, sobretudo os atores representantes das instituições privadas com fins lucrativos fizeram lobby para diminuir os impactos e as possíveis perdas financeiras.

Além dessa questão, há outra sobre a qual a autora é enfática. Diz respeito à isenção fiscal oferecida como contrapartida a essas IES privadas que, segundo ela, desviam recursos que deveriam ser direcionados ao setor público. Para Carvalho (2006),

[...] é importante ponderar que não permitir o acréscimo da isenção fiscal às IES privadas possibilitaria um maior bolo de recursos constitucionalmente garantidos ao ensino público; em outras palavras, reduzindo o financiamento indireto via renúncia fiscal em troca do crescimento no financiamento ao segmento federal. (p. 994).

No entanto, sobre o tema, vale destacar, também, a contribuição de Cunha (2007) sobre a impossibilidade dos recursos, originários das isenções oferecidas a essas instituições privadas, previstas na Lei do ProUni, serem destinadas às IES publicas. Segundo o autor,

[...] por mais que seja reprovável esse benefício público à acumulação de capital privado, é preciso reconhecer que esse processo não é reversível para as IES federais, total e automaticamente. Caso ele fosse suprimido, as IES federais não os receberiam. Isso porque apenas os recursos provenientes das contribuições têm destinação específica, a não ser em termos proporcionais, como no FUNDEF e no FUNDEB, este a partir de 2008. Assim, os recursos que iriam para o ensino (sic) superior público, caso não houvesse renúncia de impostos, obedeceriam a tratamento definido pelos orçamentos governamentais, sendo portanto, indeterminado o montante que reforçaria os orçamentos das IES pública. (p. 821).

Pode-se perceber, portanto, que a fala do autor fortalece o argumento do governo, assim como de outros estudiosos do assunto, de que os recursos não arrecadados, devido à 
isenção fiscal, não, necessariamente, iriam para o orçamento das IFES. No entanto, em relação à Lei do ProUni, pode-se afirmar que o Programa contribui não só com a ampliação da oferta de vagas de educação superior, por meio de subsídios fiscais, mas também com uma função regulatória. Pois, na medida em que aderem ao programa, as instituições que já contavam com certas isenções tributárias, como as filantrópicas, poderiam ser melhor fiscalizadas em relação à oferta de bolsas.

Toda política pública precisa ser avaliada desde sua formulação. Todas as etapas da política, sobretudo após sua execução, devem sofrer processo avaliativo a fim de corrigir rotas e identificar determinadas disfunções, além de cumprir a função de retroalimentar o Programa com novas ações que atendam melhor ao objetivo proposto.

A análise dos diferentes pontos de vista dos alunos, beneficiários ou não, demonstra o quanto o governo precisa estar atento aos ajustes e correções necessários, não só a essa política pública, mas também a qualquer outra.

Outro ponto aqui destacado diz respeito à questão da permanência do bolsista, ressaltando em que medida o Programa garante, não só seu ingresso, mas sua conclusão, tendo em vista as dificuldades enfrentadas por estudantes carentes, os quais precisam de recursos para transporte, alimentação e material exigido por sua formação.

Para reduzir essas dificuldades, o governo Lula criou a bolsa permanência, por meio da Lei, 11.180 de 2005 (BRASIL, 2005), alterada pela Lei ${ }^{\circ} 12.431$ de 2006 (BRASIL, 2006). Para Costa (2012), “a oportunidade de cursar a Educação Superior, se, por um lado, constitui uma grande oportunidade de acesso, por outro lado, pode trazer alguma dificuldade em relação à sua permanência, em função da condição socioeconômica dos seus beneficiários" (p.45). Conforme destacado pela autora, a referida Lei, de 23 de setembro de 2005 , institui que

[...] fica autorizada a concessão de bolsa permanência, no valor de $\mathrm{R} \$ 300,00$ (trezentos reais) mensais, exclusivamente para custeio das despesas educacionais, a estudante beneficiário de bolsa integral do Programa Universidade para Todos - PROUNI (sic), matriculado em curso de turno integral, conforme critérios de concessão, distribuição, manutenção e cancelamento de bolsas a serem estabelecidos em regulamento, inclusive quanto ao aproveitamento e à frequência mínima a ser exigida ao estudante. (p.46).

Para colaborar com esse debate, foi importante destacar a criação de duas comissões de natureza consultiva, uma de âmbito nacional e outra local, que foram criadas para fazer uma intermediação entre o poder público, a comunidade acadêmica e a sociedade civil. Tais 
comissões ${ }^{62}$ têm como objetivo exercer o controle social do Programa. São elas: i) Comissão Nacional de Acompanhamento e Controle Social do Programa Universidade para Todos CONAP; ii) Comissões Locais de Acompanhamento e Controle Social do Programa Universidade para Todos - COLAP, instituídas em 2006 e 2009, respectivamente, por meio de Portaria Ministerial. De acordo com a Portaria que a instituiu, compete à CONAP:

I - exercer o acompanhamento e o controle social dos procedimentos operacionais de concessão de bolsas do Prouni, visando ao seu perfeiçoamento e à sua consolidação;

II - interagir com a sociedade civil, recebendo queixas, denúncias, críticas e sugestões para apresentação à SESu;

III - propor diretrizes para organização de comissões de acompanhamento local;

IV - elaborar seu regimento, a ser aprovado em ato do Ministro de Estado da Educação; e

V - realizar reuniões ordinárias e extraordinárias. (MEC, 2006)

Ainda, conforme o que estabelece a referida Portaria $n^{0} 301$, a composição desta

Comissão se dá com

I - 2 (dois) representantes do corpo discente das instituições privadas de ensino superior, sendo pelo menos um deles bolsista do Prouni;

II - 2 (dois) representantes dos estudantes do ensino médio público;

III - 2 (dois) representantes do corpo docente das instituições privadas de ensino superior, sendo ambos professores em regime de tempo integral;

IV - 2 (dois) representantes dos dirigentes das instituições privadas de ensino superior;

V - 2 (dois) representantes da sociedade civil; e

VI - 2 (dois) representantes do Ministério da Educação.

Em maio de 2016, foi realizada a Conferência Nacional da Comissão Nacional de Acompanhamento e Controle Social do Prouni (CONAP): avaliação dos 10 anos do Programa Universidade para Todos. De acordo com o parágrafo $2^{\circ}$ do Regimento da referida Conferência, seu objetivo é:

I - reafirmar e ampliar o compromisso do Estado e da sociedade brasileira com as políticas públicas educacionais de acesso e permanência no ensino superior;

II - reafirmar os princípios constitucionais da Educação, da Cidadania, da Democracia e dos Direitos Humanos, com base na Dignidade da Pessoa Humana;

${ }^{62}$ A CONAP e COLAPs foram instituídas pela Portaria $\mathrm{n}^{\mathrm{o}}$ 301, de 30 de janeiro de 2006 (MEC, 2006) e pela Portaria $\mathrm{n}^{\circ} 1.132$, de 2 de fevereiro de 2009 (MEC, 2009), respectivamente. 
III - fortalecer a participação social na análise, fiscalização, (re)construção, implementação e monitoramento do Prouni;

IV - propor estratégias e mecanismos de aprimoramento da fiscalização, controle, participação e implementação do Programa;

V - articular o Sistema Nacional de Fiscalização e Acompanhamento do Prouni, nas diversas instâncias que o compõe, principalmente COLAPs e CONAP;

VI - discutir e propor estratégias de enfrentamento à violência contra grupos sociais vulneráveis dentro do Prouni, especialmente a discriminação por raça/etnia, cor, sexo, gênero, orientação sexual, religião, idade e condição econômica.

VII - Aprimorar a política em suas diversas vertentes, fazendo um balanço dos dez anos do Prouni: principais desafios e perspectivas (MEC, 2016).

É importante abordar essas ações, tendo em vista serem pouco citadas pelos estudiosos do Programa. Ressalta-se a relevância do acompanhamento das políticas públicas, pela sociedade civil, para seu aprimoramento e correção de possíveis irregularidades. Acredita-se que avanços estão sendo realizados para que o foco do Programa seja aperfeiçoado, assim como sua fiscalização e controle.

Nesse sentido, destaca-se a relevância das comissões locais, considerando que são as que têm mais condições de acompanhar de perto a gestão do Programa junto à IES, fiscalizando possíveis irregularidades de modo a permitir que a referida política cumpra o papel social que tem como objetivo.

Em 2014, o ProUni completou dez anos de existência. A oferta de vagas, nas instituições privadas de educação superior, por meio das bolsas da referida política, é crescente. Para continuar essa curva, representantes da Associação Brasileira de Mantenedoras de Ensino Superior - $\mathrm{ABMES}^{63}$ sugerem a alteração nas regras para a concessão das bolsas, como o aumento da faixa de renda e a possibilidade de alunos que já estudaram em escola particular (dependendo do porte da instituição) também possam ser contemplados pelo Programa ${ }^{64}$.

Assim como em toda política pública, muitas foram as críticas, positivas e negativas, acerca deste Programa. No entanto, há uma realidade que não se pode negar: o ProUni aumentou o acesso de estudantes à educação superior, conforme dados já apresentados. Nesse

\footnotetext{
63 A ABMES foi criada em 1982 como "entidade de direito privado, com personalidade jurídica própria". Segundo o site da associação, ao longo de sua história, a entidade "consolidou sua presença no cenário educacional do país - por meio de uma contribuição decisiva na área acadêmica e no âmbito político, visando ao fortalecimento do ensino superior particular [...]" (ABMES, 2015).

${ }^{64}$ Foi realizado em novembro de 2015 um Seminário para se discutir os rumos do ProUni, com a participação da Coordenação-Geral de Projetos Especiais para Graduação do MEC. Nesse evento, a consultoria jurídica da Associação trouxe ao debate a questão da ampliação das regras para concessão das bolsas do Programa.
} 
sentido, é preciso reconhecer que, pelo menos em termos quantitativos, o ProUni contribuiu com a relativa alteração do cenário educacional brasileiro.

\subsection{OProUni e o Plano Nacional de Educação 2014/2023: acesso, permanência e qualidade - desafios para o próximo decênio}

Conforme foi visto ao longo desta pesquisa, o Programa Universidade para Todos é uma das políticas citadas no novo Plano Nacional de Educação 2014/2024, aprovado pela Lei $\mathrm{n}^{\mathrm{o}} 13.005$ de 25 de junho de 2014 (BRASIL, 2014), para contribuir com a meta que prevê o índice de $33 \%$ de jovens entre 18 e 24 cursando uma graduação até o final do decênio em questão.

Ao analisar, tendo em vista as metas e estratégias estabelecidas pelo PNE/2014, os desafios a serem superados, Santos e Ferreira (2015) observaram que o modelo diversificado de instituições e cursos, que compõe o sistema federal de educação superior, e a relação público-privada contribuem para a problematização do debate acerca do acesso a esse nível educacional. As referidas autoras destacam que na discussão em torno do texto do novo Plano um dos pontos mais polêmicos foi o relacionado ao percentual do Produto Interno Bruto PIB - que seria investido na área.

Para os defensores do setor público, não se admitia colocar programas como o ProUni e o Fies nessa conta, pois, segundo as autoras, esse diz respeito a financiamento e aquele à renúncia fiscal, "não fazendo sentido, portanto, serem computados no investimento direto com educação, tendo em vista que não é uma verba que se relaciona com os percentuais constitucionais que o MEC investe na área” (p. 62).

Essa discussão integra a polêmica acerca da privatização da educação superior, que remete à época da ditadura militar, conforme já destacado nesta pesquisa. Para quem defende que verba pública deve ir para o setor público, o embate presente nessa discussão é desafiador. Afinal, como negar que o setor privado é parte importante no processo de expansão e democratização do acesso a esse nível educacional?

Ao abordar a questão do financiamento da educação brasileira, considerando o Produto Interno Bruto (PIB) do país, Lima (2015) mostra como se deu a alocação desses valores no ano de 2011 e critica o baixo investimento no setor. Segundo ela, dados do Inep (2011) apontaram que 
[...] os valores alocados para a Educação em relação ao Produto Interno Bruto - PIB têm sido ínfimos. Para toda a área da educação, incluindo Educação Infantil, Básica, Ensinos Fundamental, Médio e Superior, o Brasil aplicou 4,6\% do PIB em 2003 e 6,1\% do PIB em 2011. Destes valores, apenas 0,9 do PIB foi alocado para a Educação Superior em 2003 e 1,0\% em 2011(p. 38).

A partir dessas informações, fica fácil compreender a insatisfação de quem não aceita dividir o "bolo" com o setor privado. Para esses, os recursos previstos com o aumento do PIB em educação deve ser integralmente voltado à valorização do setor público. Entenda-se desse raciocínio, que essa seria uma maneira de mudar a lógica do modelo privatista da educação superior que perdura desde os anos 1960.

A autora destaca ainda que ao indicar o Fies e o ProUni como destinatários do financiamento público em educação, definido na Meta 20 do PNE/2014, a lei está privilegiando o setor privado. Essa constatação dá-se ao analisar a estratégia 12.6 do referido plano, a qual prevê a expansão do financiamento estudantil, com a constituição do fundo garantidor, de forma a dispensar a exigência de fiador. Além disso, na estratégia $12.20 \mathrm{o}$ Plano propõe ampliar, no âmbito desses dois programas, "os benefícios destinados à concessão de financiamento a estudantes regularmente matriculados em cursos superiores privados presenciais ou a distância” (p. 40).

Para entender melhor os desafios que se impõem diante das metas estabelecidas pelo $\mathrm{PNE} / 2014$, vale a pena rever a que diz respeito à educação superior. A de número 12 prevê

[...] elevar a taxa bruta de matrícula na educação superior para $50 \%$ (cinquenta por cento) e a taxa líquida para $33 \%$ (trinta e três por cento) da população de 18 (dezoito) a 24 (vinte e quatro) anos, assegurada a qualidade da oferta e expansão para, pelo menos, $40 \%$ (quarenta por cento) das novas matrículas, no segmento público (BRASIL, 2014).

Esses objetivos, contudo, não podem ser considerados, nem de longe, fáceis de atingir, tendo em vista os déficits educacionais brasileiros. Para ilustrar isso, basta dizer que a meta estabelecida pelo PNE de 2001 do alcance de 30\% de taxa de escolarização líquida não foi atingida, mesmo diante da expansão dos últimos anos, tanto da esfera pública, quanto privada. Longe desse índice, o alcance foi de menos de $18 \%$ da população entre 18 e 24 na educação superior.

Portanto, para que fosse possível atingir a meta estabelecida no Plano Nacional de Educação 2014/2024 até o final do decênio o sistema de educação superior deveria incorporar mais de quatro milhões de novas matrículas, tanto de estudantes - de qualquer idade (taxa 
bruta) - quanto da faixa etária relacionada à taxa líquida (18 a 24 anos). Significa dizer que mais de oito milhões de estudantes deveriam ingressar numa instituição de educação superior até o ano de 2024. Já, para o alcance de 40\% de novas matrículas no setor público, deveriam ser admitidos mais de um milhão e setecentos mil alunos nas universidades públicas. (SANTOS; FERREIRA, 2015).

Para melhor visualizar o desafio posto pelo PNE 2014/2024, segue gráfico com a projeção da meta em números absolutos para que seja possível ter uma dimensão objetiva do quanto deverá ser realizado, em termos de políticas públicas, para que se promova esse salto na expansão no número de matrículas. Conforme ilustração gráfica, para que seja possível alcançar os índices bruto e líquido, previsto na meta, praticamente o mesmo número de alunos (das respectivas faixas etárias) deverão ingressar na educação superior até 2024, cerca de quatro milhões, para cada grupo.

\section{Gráfico 9 - Projeção da meta 12 do PNE 2014/2024 - Educação Superior}

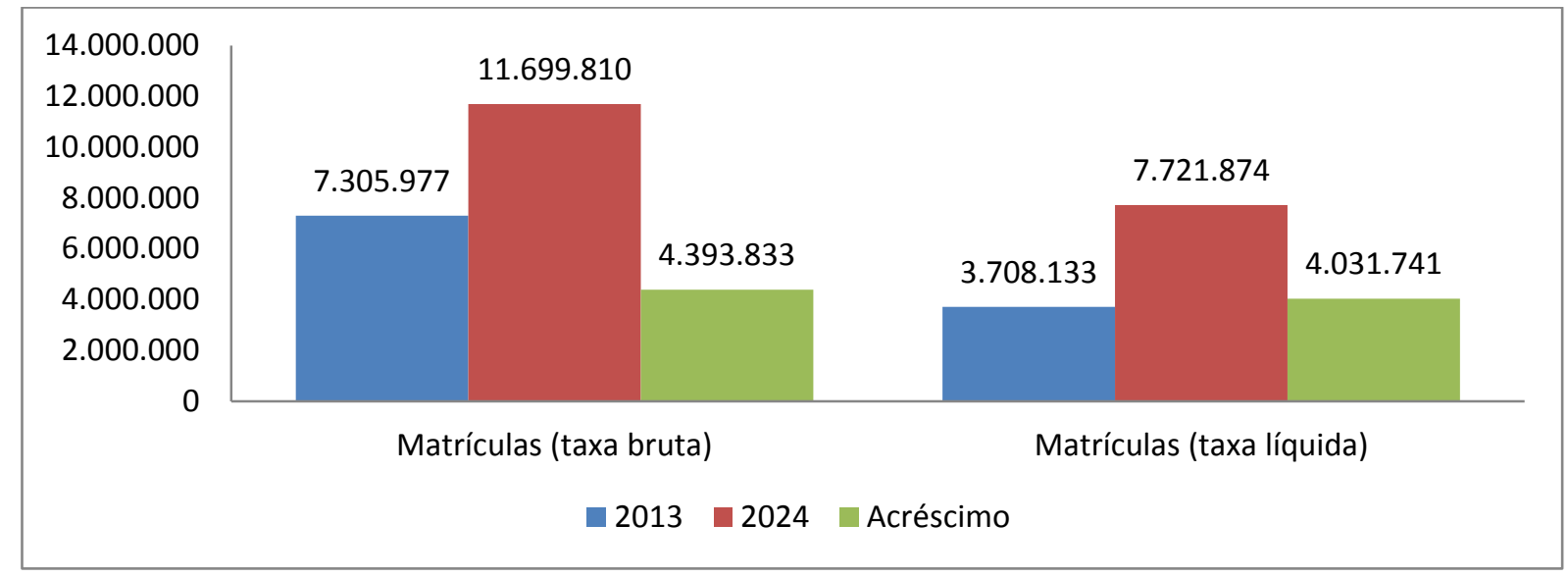

Elaboração própria a partir de dados de Santos e Ferreira (2015, p. 63).

Não se pode perder de vista que essa ampliação do número de alunos matriculados deve ser acompanhada de justa distribuição das vagas, em relação à heterogeneidade prevista na formação da população (cor/raça), segundo dados do IBGE, assim como em relação às desigualdades regionais e socioeconômicas, marcantes na sociedade brasileira. Caso contrário, a propalada democratização do acesso a esse nível educacional não estaria sendo alcançada.

Por fim, vale destacar a meta 13 , a qual diz respeito a outra dimensão importante e que deve ser considerada ao analisar o processo de democratização à luz da inclusão social, conforme abordado nessa pesquisa. As referidas autoras observam que ao generalizar a 
exigência de formação dos docentes para atingir uma melhoria da educação superior, a rede privada se beneficiaria, pois, na medida em que as "IES públicas aumentem significativamente seu percentual de mestre e doutores, a meta será atingida sem que a rede privada necessite elevar a qualificação do seu corpo docente" (p.68).

Nesse sentido, percebe-se, novamente, a preocupação com a diferença entre a oferta do setor público e do setor privado. No entanto, há uma realidade inescapável: não há, na atualidade, como desprezar o potencial do setor privado, considerando que ele abarca o maior número de matrículas desse nível de ensino e que programas como o ProUni se tornaram fundamentais para contribuir com a ampliação e democratização do acesso à educação superior. Cabe ao Estado garantir meios de permanência do aluno, assim como uma oferta que tenha qualidade para que ao formar o bolsista se tenha a convicção de que esse foi, de fato, beneficiado por uma política capaz de reduzir as assimetrias que tão mal fazem à sociedade brasileira.

Para ter uma visão mais concreta acerca dos impactos proporcionados pelo ProUni, esta pesquisa propôs entrevistar alguns gestores, assim como alguns bolsistas, de quatro cursos diferentes, de uma instituição privada do Distrito Federal, conforme anunciado nas considerações iniciais. Para tanto, faz-se necessário contextualizar a expansão da educação superior privada na região, para inserir o tema da maneira mais adequada. A instituição será abordada dentro desse cenário de expansão regional da educação superior, a luz de uma política nacional, implementada no governo Lula.

\subsection{A expansão da educação superior privada no Distrito Federal: um olhar a partir do governo Lula}

Este trabalho propôs analisar o ProUni a partir de uma instituição privada do Distrito Federal. Para tanto, considerou-se necessário abordar o fenômeno da expansão da educação superior, dessa modalidade administrativa, na referida região. Assim como aconteceu em âmbito nacional, o DF também passou por forte ampliação dessa rede de instituições de educação superior a partir da década de 1990. No entanto, nessa parte do capítulo o tema é abordado apenas a partir da gestão de Lula, por ser o período em que Programa Universidade para Todos se inseriu, inicialmente.

Todavia, antes de analisar tal fenômeno, foi feito um breve histórico da região a fim de se apresentar algumas características demográficas e socioeconômicas que descrevam, em linhas gerais, as assimetrias presentes na sociedade brasiliense. O Distrito Federal é formado 
por trinta e uma regiões administrativas (RA). Quando Brasília foi inaugurada, em 21 de abril de 1960, foi previsto, em seu plano urbanístico, cidades satélites que serviriam como núcleos periféricos ao Plano Piloto. Em 1964, para facilitar a administração dessas localidades, deu-se a divisão do território em oito regiões administrativas. (BRASÍLIA/DF, 2014). De acordo com explicação de Sousa (2013),

[...] criadas pela Lei $\mathrm{n}^{\circ} 4.545 / 1964$ (GDF,1964), Art. 10, as RAs correspondem a áreas territoriais do DF pelo fato de esta Unidade Federativa ser considerada uma e não poder ter municípios. Desde então, as áreas que foram sendo criadas ao redor de Brasília passaram a ser chamadas de "cidades satélites". Todavia, a partir da promulgação da Lei Orgânica do Distrito Federal, em 1993, Região Administrativa passou a ser a denominação oficial dessas cidades, que passaram a ser instituídas por leis distritais (p.56)

A seguir, apresenta-se quadro com a relação de todas as Regiões Administrativas que compõem o Distrito Federal.

Quadro 2 - Regiões Administrativas e data de criação - 2014 - Distrito Federal

\begin{tabular}{|l|c|}
\hline Região Administrativa & \begin{tabular}{c} 
(continua) \\
\hline RA I - Brasília/Plano Piloto
\end{tabular} \\
\hline RA II - Gama & $10 / 12 / 1964$ \\
\hline RA III - Taguatinga & $10 / 12 / 1964$ \\
\hline RA IV - Brazlândia & $10 / 12 / 1964$ \\
\hline RA V - Sobradinho & $10 / 12 / 1964$ \\
\hline RA VI - Planaltina & $10 / 12 / 1964$ \\
\hline RA VII - Paranoá & $10 / 12 / 1964$ \\
\hline RA VIII - Núcleo Bandeirante & $10 / 12 / 1964$ \\
\hline RA IX - Ceilândia & $25 / 10 / 1989$ \\
\hline RA X - Guará & $25 / 10 / 1989$ \\
\hline RA XI - Cruzeiro & $25 / 10 / 1989$ \\
\hline RA XII - Samambaia & $25 / 10 / 1989$ \\
\hline RA XIII - Santa Maria & $25 / 10 / 1989$ \\
\hline RA XIV - São Sebastião & $04 / 11 / 1992$ \\
\hline RA XV - Recanto das Emas & $25 / 06 / 1993$ \\
\hline RA XVI - Lago Sul & $28 / 07 / 1993$ \\
\hline
\end{tabular}


Quadro 2 - Regiões Administrativas e data de criação - 2014 - Distrito Federal

\begin{tabular}{|l|c|}
\hline \multicolumn{1}{|c|}{ (conclusão) } \\
\hline Região Administrativa & Data da criação \\
\hline RA XVII - Riacho Fundo & $15 / 12 / 1993$ \\
\hline RA XVIII - Lago Norte & $10 / 01 / 1994$ \\
\hline RA XIX - Candangolândia & $27 / 01 / 1994$ \\
\hline RA XX - Águas Claras & $06 / 05 / 2003$ \\
\hline RA XXI - Riacho Fundo II & $06 / 05 / 2003$ \\
\hline RA XXII - Sudoeste/Octogonal & $06 / 05 / 2003$ \\
\hline RA XXIII - Varjão & $06 / 05 / 2003$ \\
\hline RA XXIV - Park Way & $29 / 12 / 2003$ \\
\hline RA XXV - SCIA (Estrutural) & $27 / 01 / 2004$ \\
\hline RA XXVI - Sobradinho II & $27 / 01 / 2004$ \\
\hline RA XXVII - Jardim Botânico & $31 / 08 / 2004$ \\
\hline RA XXVIII - Itapoã & $03 / 01 / 2005$ \\
\hline RA XXIX - SIA ${ }^{\mathbf{1}}$ & $14 / 07 / 2005$ \\
\hline RA XXX - Vicente Pires & $26 / 05 / 2009$ \\
\hline RA XXXI - Fercal & $29 / 01 / 2012$ \\
\hline
\end{tabular}

Fonte: PDAD/DF 2013 (BRASÍLIA, 2014, p.20).

Nota: (1) SCIA - Setor Complementar de Indústria e Abastecimento - inclui a Vila Estrutural (2) SIA - Setor de Indústria e Abastecimento

De acordo com a PDAD/DF de 2013, “com a evolução territorial, por meio da Lei $\mathrm{n}^{\circ}$ 49, de 25 de outubro de 1989 e do Decreto $\mathrm{n}^{\circ} 11.921 / 89$, procedeu-se a nova divisão em 12 RAs” (p. 19). A partir de então, foram vários movimentos nesse sentido: em 1993 foram criadas mais três RA; em 1994, quatro; em 2003 mais quatro; em 2004 três e, por fim, em 2012 foi criada a RA XXXI, chamada Fercal (BRASÍLIA, 2014).

Essas regiões administrativas são distribuídas em um território de 5.779 .999 km², cuja densidade demográfica, segundo Censo de 2010, era de 446,66 hab/km². (IBGE, 2010). Em 2013, o número de habitantes era de 2.786.684, distribuídos entre 51,98\% de mulheres, $65,56 \%$ com idade entre 15 e 59 anos. A renda domiciliar média da população do DF nesse ano foi de $\mathrm{R} \$ 5.015,04$ (6,93 salários mínimos - SM) e a renda per capita de $\mathrm{R} \$ 1.489,57$ (2,20 SM), segundo dados da PDAD/DF 2013 (BRASÍLIA, 2014).

Alguns dados demonstram que o Distrito Federal apresenta melhores índices relacionados à qualidade de vida que os do Brasil, como a expectativa de vida e o índice de 
desenvolvimento humano (IDH). Segundo a PNAD 2014, as mulheres têm no Brasil uma expectativa de vida de 78,8 anos de idade e no DF esse dado corresponde a 81,0 anos. Em relação ao IDH, segundo o Atlas Brasil 2013 (Pnud), o país apresentou o valor de 0,7269 e o Distrito Federal de 0,8238 (CODEPLAN, 2016). Além desses, existem outros dados onde mostram que, apesar das grandes diferenças sociais, o DF apresenta melhores condições de vida que a média nacional. Em relação ao critério de raça/cor apresentada pela PDAD/DF 2013, a população do DF é assim distribuída:

\section{Tabela 6 - Proporção da população por raça/cor - Distrito Federal, 2013}

\begin{tabular}{|c|}
\hline Cor/raça \\
\hline Parda e mulata \\
\hline Preta \\
\hline Branca \\
\hline Amarela \\
\hline Indígena \\
\hline Não sabe \\
\hline
\end{tabular}

Distribuição percentual (\%)

Fonte: PDAD/DF, 2013 (BRASÍLIA, 2014).

Essa tabela apresenta um dado que se assemelha ao apresentado em nível nacional. O grupo representado pelos pardos/mulatos e pretos, cuja soma, segundo interpretação do IBGE, representa a parcela de negros, corresponde à maioria da população -

$54,74 \%$. No Brasil, essa representação é de 53,60\%, portanto, tanto em âmbito nacional, quanto regional (DF), a população é formada, majoritariamente, por negros.

Quando a pesquisa realizada pela Companhia de Planejamento do DF - Codeplan fez um cruzamento entre raça/renda e local de moradia, concluiu-se que nas regiões de maior renda prevalecem a cor branca que, em sua maioria moram no Lago Sul $(80,27 \%)$, Sudoeste/Octogonal (73,76\%) e Jardim Botânico (66,43\%) (BRASÍLIA, 2014).

Esses dados corroboram algumas informações já explicitadas neste trabalho, como a predominância branca da população de maior renda, assim como sua preponderância em relação ao maior grau de instrução. Em relação ao nível de escolaridade da população do DF, a Pesquisa Distrital por Amostra de Domicílios (PDAD/DF) mostrou que 17,27\% tem formação superior (incluindo Especialização, Mestrado e Doutorado). Segundo esse levantamento, os resultados mostraram ainda que os mais instruídos moram em regiões de alta renda, como Lago Norte (67\%), Lago Sul (71,30\%) e Sudoeste/Octogonal (74,69\%), 
enquanto nas regiões de baixo poder aquisitivo o número de pessoas que possuem nível superior é muito baixo, como SCIA/Estrutural com 3,10\% (BRASÍLIA, 2014).

Em que pese a situação mais favorável do Distrito Federal, em comparação com o Brasil, ainda assim, fica evidente que a desigualdade socioeconômica também faz parte da realidade regional. Diante disso, conclui-se que políticas sociais com foco na educação também precisam ser implementadas na capital do país e demais RA. De acordo com o PDAD 2013

[...] em razão da alta correlação entre a renda e a educação, a forma eficiente de combater as desigualdades observadas no Distrito Federal, a médio e longo prazo, consiste em investimentos em educação. As políticas públicas voltadas para a educação permitirão que a população historicamente (excluída do processo do desenvolvimento social) tenha acesso ao ensino de qualidade até o nível superior. A qualificação profissional, não apenas em nível técnico, também garante melhoria da renda da população na medida em que os empregos de alta remuneração exigem uma melhor qualificação (BRASÍLIA, 2014, p.34).

O Programa Universidade para Todos é um programa que contribui para inserir parte dessa população no grupo de pessoas com acesso à formação superior. De 2011 a 2015 foram ofertadas no DF 52.416 bolsas (integrais e parciais), dessas, 22.443 integrais. O número de bolsas ofertadas em todo o Brasil nesse mesmo período foi de 1.427.437. Esses dados mostram significativa ampliação do acesso a esse nível educacional pela via privada. Nesse sentido, considera-se relevante entender como se constituiu o cenário da educação superior no DF, no âmbito das instituições privadas, por serem estas as responsáveis pela oferta das bolsas do ProUni.

Como já foi dito aqui, o Programa Universidade para Todos foi pensado como uma das formas de contribuir com a meta prevista no PNE/2001 de atingir 30\% de taxa líquida (jovens de 18 a 24 anos) na educação superior. No DF, segundo PNAD 2013, esse índice era de $31,6 \%$, bem acima dos $16,4 \%$ da taxa nacional. Entre os estudantes que frequentam estabelecimentos de ensino, em relação à educação superior, 19,3\% estão na rede pública e 80,7\% na privada (IBGE, 2014). Assim como em âmbito nacional, o Distrito Federal também se caracteriza por ser representado, majoritariamente, pelas IES privadas.

Sobre a expansão da educação superior privada no DF, Martins (1997) atribuiu, dentre os motivos, o crescimento populacional da capital federal e o fato de Brasília ser 
compõem este setor econômico, e de um modo destacado os participantes da administração pública, tendem a associar as suas chances de ascensão e sucesso social à obtenção de títulos escolares, voltando portanto as suas atenções principalmente para o ensino de terceiro grau. Estas circunstâncias têm possibilitado a formação de um mercado potencial de consumidores de produtos educacionais que certamente não passou despercebido pelos grupos responsáveis pela criação e desenvolvimento do ensino superior privado local (p.162).

Outros dois fatores que merecem destaque, segundo identificado por Martins (1997), para explicar o fenômeno de expansão das IES privadas no DF, sobretudo a partir da década de 1970, estão relacionados à

[...] ausência do ensino noturno na universidade local que vem sendo introduzido lentamente a partir do final da década passada, ao frustrar os anseios de acesso ao ensino superior público por parte de candidatos que trabalham, tem constituído provavelmente um outro elemento explicativo na dinâmica das instituições particulares [...] Deve-se também acrescentar que este ensino particular tem procurado direcionar-se de forma prioritária para atender uma demanda potencial definida em grande medida pelas necessidades da produção e reprodução da burocracia pública estatal (p. 163).

De fato, o Distrito Federal, por abrigar a capital do país, tem uma população composta por um grande número de servidores públicos e esses, em geral, tendem a procurar melhor formação para ascender profissionalmente no órgão em que exerce suas funções. Ademais, conforme observado pelo autor, grande parte dessas pessoas trabalham o dia todo, não restando outro período para frequentar uma IES que não o noturno. Para tanto, a iniciativa privada, atenta a essa demanda, expandiu, significativamente, a oferta de cursos à noite. Para ilustrar a hegemonia das IES privadas na região, segue a relação nominal, até 1991 (MARTINS, 1997). Existiam no DF $15^{65}$ instituições de educação superior, criadas a partir de 1962, sendo apenas uma pública. São elas:

1. Instituto Rio Branco - IRBR ${ }^{66}$

2. Universidade de Brasília - UnB

3. Instituto de Ciências Sociais - ICS-AEUDF

4. Centro de Ensino Unificado de Brasília - CEUB

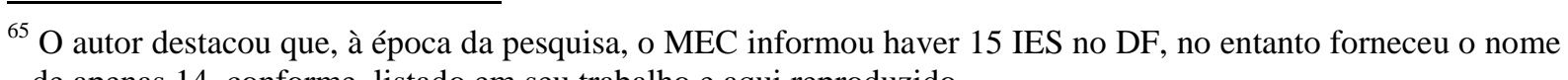
de apenas 14 , conforme listado em seu trabalho e aqui reproduzido.

${ }^{66}$ O Instituto Rio Branco foi criado no Rio de Janeiro, em 1945, e é vinculado ao Ministério das Relações Exteriores. A instituição é responsável pelo processo seletivo para a carreira de diplomata. Atualmente a seleção é feita com a colaboração do Centro de Seleção e Promoção de Eventos da Universidade de Brasília CEBRASPE (MRE/IRB, 2016). 
5. Faculdades Integradas da UPIS - UPIS

6. Faculdades Integradas da Católica de Brasília - FICB

7. Faculdade Bom Bosco de Educação Física - FDBEF

8. Faculdade de Artes - Fundação Brasileira de Teatro (Faculdade Dulcina) - FA-FBT

9. Instituto de Ciências Sociais Aplicadas - ICSA

10. Faculdade de Odontologia do Planalto Central - FOPLAC

11. Faculdade Alvorada de Informática e Processamento de Dados

12. Instituto de Ciências Exatas - ICEX-AEUDF

13. Faculdade de Reabilitação do Planalto Central - FARPLAC

14. Faculdade de Ciências Humanas de Brasília - FCHBSB

De acordo com análise feita por Sousa (2013), o processo de constituição do campo da educação superior no DF pode ser dividido em três grandes momentos. Nesse sentido, as IES citadas fizeram parte da primeira fase, retratada pelo autor como "gênese e instalação das primeiras instituições (1962 a 1994)" (p. 97). A segunda fase deu-se entre 1995 e 2002, momento em que houve uma forte expansão, sobretudo pelo setor privado, e quando surgiu a segunda IES pública do DF. Entre 2003 a 2010 deu-se “a intensificação do processo concorrencial que se instala entre as instituições, particularmente aquelas ligadas ao setor privado, e sinais de exaustão desse mesmo setor" (p. 97).

O ProUni surgiu exatamente no período marcado pela concorrência e esgotamento das IES privadas, segundo avaliação de Sousa (2013). Em 2004, o então Presidente Lula assinou a medida provisória instituindo o programa e, devido a essa característica destacada pelo autor, acerca da situação em que se encontravam as IES privadas, não só no DF, mas em todo o Brasil, o governo foi acusado de preencher as vagas ociosas do setor e de ter criado a referida política para salvar essas instituições, devido à saturação já identificada.

Apenas para contextualizar, o período definido pelo referido autor como o segundo momento (1995-2002) do processo de composição do campo da educação superior no DF abarcou todo o governo de FHC. Durante esses oito anos foram criadas 52 IES privadas no Distrito Federal. Conforme explicou Sousa (2013),

[...] as motivações para a criação das IES privadas, no período entre $1995 \mathrm{e}$ 2002, em várias Regiões Administrativas do DF, foram convergentes para dois grandes eixos - a existência de uma demanda de pessoas interessadas na educação superior e o fato de a quase totalidade de instituições vinculadas a este setor ter sido instada, no período anterior (1968-1994), basicamente na 
região de Brasília. Essas motivações também orientaram a continuidade da consolidação do subcampo privado local, entre 2003 e 2010 (p.207).

De fato, a região do Distrito Federal se expandiu bastante ao longo dos anos e sua população também. Diante dessa realidade e da própria demanda por mais formação, deu-se o movimento de instalação de IES em outras regiões administrativas, como Taguatinga, Ceilândia e Guará. No entanto, durante o governo Lula esse aumento foi menor e chegou a registrar em 2008 uma redução de dez estabelecimentos privados, o que correspondeu a uma redução de 13,1\% do total, passando de 76 para 66, em 2009 (SOUSA, 2013). Segundo o autor, a fusão de algumas IES e a compra de instituições locais por grupos oriundos de outra unidade federativa pode explicar essa redução.

Vale observar que, apesar de ter havido essa diminuição de IES privadas nesse período, ainda assim sua hegemonia é indiscutível, considerando que o DF conta com apenas duas instituições públicas de educação superior, sendo elas a UnB e a ESCS. Outra característica importante diz respeito ao caráter essencialmente empresarial de algumas instituições, administradas por gestores que nada entendem de educação, mas sabem como ganhar dinheiro. Nesse sentido, o olhar mercadológico foi aprofundado, sobretudo, a partir da possibilidade de negociar ações das IES na bolsa de valores. Para Sousa (2013) os empresários da educação se dividem em dois grupos. Sendo

[...] um desses grupos, formado por agentes que mantinham pouca ou nenhuma relação com o setor educacional, interessou-se pelos lucros que acreditavam dele advirem, enquanto o outro, constituído por proprietários de escolas de educação básica, viu na educação superior a possibilidade de atuar em outro nível educacional (p. 203).

No entanto, esse movimento promoveu uma grande oferta que se configurou, mais tarde, em vagas ociosas, devido ao "estoque de vagas" feito pelas IES privadas, no momento de sua solicitação junto ao Ministério da Educação. Outro fator que contribuiu para o perfil mercadológico de oferta de educação superior no país, diz respeito à criação de vagas visando atender ao mercado, prioritariamente, sendo verificado também no DF, nas últimas décadas (SOUSA, 2013).

Ainda segundo o autor, o Programa Universidade para Todos "mantem relação direta com a questão das vagas ociosas na rede privada [...] e no caso do DF, em 2007 um conjunto de 38 instituições participava do ProUni, o que correspondia a 50,0\% do total " (p. 225). No entanto, apesar desta característica, não há como negar o caráter social do programa, ao 
incluir parcela da população que, até então, não tinha a menor chance de frequentar uma instituição de educação superior.

Conforme ilustraram alguns dados sobre a população do DF, pode-se observar que, assim como no cenário nacional, as desigualdades sociais se fazem bastante presente. Portanto, em que pese às críticas relacionadas à referida política, o objetivo de ampliar as matrículas desse nível educacional, assim como de democratizar seu acesso, com a inclusão de carentes e negros, nessas IES, está sendo alcançado, mesmo que timidamente. E, em relação às vagas ociosas, Sousa (2013) considera que

[...] na prática, por meio do ProUni, o governo acabou fazendo concessões a grande parte das reivindicações do setor privado, induzindo as instituições que dele fazem parte a oferecer bolsas a estudantes de baixa renda em troca de isenções fiscais. Todavia, nem mesmo com essa intenção o referido programa tem se mostrado eficiente em relação a uma possível redução do número de vagas ociosas no setor privado da educação superior (p.226).

Essa discussão deve ser considerada, mas o ProUni tem um arcabouço social que transcende o tema meramente fiscal. Com mais de dez anos, o programa alcançou milhares de pessoas em todo o Distrito Federal, dentre elas, os principais elegíveis (carentes) e outros que tem nas ações afirmativas garantia de elegibilidade, como os negros e pessoas com deficiência, ou mesmo os indígenas.

A instituição do DF escolhida para compor essa pesquisa promove, por meio do programa, o ingresso de estudantes em cursos de alta demanda e alto custo e, segundo os gestores entrevistados, os bolsistas apresentam desempenho tão bom ou até superior aos não bolsistas.. Uma das explicações para tal seria a de que o bolsista valoriza a referida política e a considera uma grande oportunidade para alcançar seus objetivos acadêmicos e profissionais. Portanto, apesar dos desacertos em relação à política de educação superior no país, não há como desprezar o ganho individual daqueles que, em muitos casos, representam a primeira pessoa da família a ter um diploma de nível superior.

Esse apelo social do programa é inegável. Portanto, talvez seja necessário atingir outro patamar de discussão acerca dos alcances do ProUni - tanto em termos institucionais, quanto individuais. No que diz respeito ao Distrito Federal, considerando que o número de instituições públicas é muito reduzido (2), a existência de políticas voltadas ao setor privado deve ser avaliada, em algum momento, pela sua capacidade de contribuir para a democratização do acesso a esse nível educacional, considerando categorias como qualidade da oferta e equidade, entendida como inclusão social. 
No próximo capítulo foram abordados os resultados desta pesquisa, a partir da análise das respostas, dos questionários enviados aos alunos-bolsistas, assim como das entrevistas feitas aos gestores do Ministério da Educação e da instituição pesquisada. A referida análise priorizou o cruzamento dos dados obtidos pelos instrumentos. Além disso, tentou-se construir um diálogo entre os dados e o referencial teórico, de forma dialética, explicitando, sobretudo, as contradições presentes no fenômeno abordado. Tal caminho metodológico teve a intenção de responder à questão proposta, assim como, de alcançar os objetivos geral e específicos, definidos nas considerações iniciais deste trabalho. 


\section{CAPÍtUlo 3 - O PROUNi E SEUS SUJEITOS: AVALIANDO EFEITOS E IMPACTOS}

Esse capítulo aborda os resultados da pesquisa, a partir do objetivo proposto. Para responder à questão que pautou este trabalho, foram utilizados diferentes caminhos. Diversos dados foram levantados por meio de documentos oficiais, como pesquisas institucionais (Pnad/IBGE; PDAD/Codeplan), censos educacionais (Censo da educação superior/INEP), legislações variadas (Constituições, Leis, Decretos, Portarias), assim como atas e dados estatísticos. Além desses, as entrevistas e o questionário também compuseram o rol de instrumentos para o mesmo fim.

Apresentam-se, neste capítulo, os resultados das análises qualitativa e quantitativa dos dados colhidos para a pesquisa. Com o objetivo de traçar o perfil dos bolsistas, foi utilizado o software Statistical Package for the Social Sciences (SPSS), versão 18.0, para sistematizar os dados. O programa ajudou na composição socioeconômica dos bolsistas, assim como na análise de suas respostas acerca do programa. Para tanto, utilizou-se a técnica do desvio padrão e do coeficiente de variação, ao analisar as respostas das questões intervalares, propostas no questionário. A referida técnica é a mais indicada para esse tipo de questão, segundo sugere Levin; Fox e Forde (2012), por medir o grau de variabilidade das respostas.

Para as entrevistas semiestruturadas realizadas, pessoalmente, com os sujeitos propostos, foi utilizada a análise de conteúdo, de caráter qualitativo. Segundo Franco (2008), essa metodologia é "a sistematização das mensagens, de seus enunciados, de seus locutores e de seus interlocutores" (p. 7). Nesse sentido, a escolha desse caminho metodológico teve o objetivo de analisar como as categorias selecionadas a priori seriam abordadas pelos entrevistados.

Ainda segundo a autora, "torna-se indispensável considerar que a relação que vincula a emissão das mensagens (que podem ser uma palavra, um texto, um enunciado ou até um discurso) está necessariamente articulada às condições contextuais de seus produtores” ( $\mathrm{p}$. 19). Significa dizer que a as respostas devem ser analisadas à luz da realidade de cada respondente, considerando sua ligação com o tema. Como será observado, as respostas assumem diferentes visões sobre o mesmo assunto. Isso se deve ao fato de que cada sujeito da pesquisa vê o fenômeno pesquisado, no caso, a contribuição do ProUni para a democratização do acesso à educação superior, sobre um prisma diferente. 


\subsection{Perspectivas de análise e interpretação dos dados}

Para analisar o processo de expansão e democratização do acesso à educação superior ocorrida nos últimos anos, com ênfase no ProUni e seu impacto no Distrito Federal, optou-se por considerar as categorias metodológicas: contradição, totalidade, parcialmente e a mediação, próprias do materialismo histórico dialético, a fim de ajudar na compreensão do tema. Sobre essas categorias, Kuenzer (2011) descreveu seus pressupostos, de forma sintética, conforme quadro explicativo a seguir:

\section{Quadro 3 - Categorias do Materialismo Histórico Dialético}

\begin{tabular}{l|l}
\hline Totalidade & $\begin{array}{l}\text { [...] esta categoria implica na concepção da realidade enquanto um todo em processo } \\
\text { dinâmico de estruturação e de autocriação, onde os fatos podem ser racionalmente } \\
\text { compreendidos a partir do lugar que ocupam na totalidade do próprio real e das } \\
\text { relações que estabelecem com os outros fatos e com o todo; onde os fatos são parte } \\
\text { integrante de um processo de concretização que se dá através do movimento e das } \\
\text { relações que ocorrem das partes para o todo e do todo para as partes, dos fenômenos } \\
\text { para a essência e vice-versa [...] (p.64). }\end{array}$ \\
\hline Contradição & $\begin{array}{l}{[. . \text { ] a pesquisa deverá buscar captar a todo momento o movimento, a ligação e }} \\
\text { unidade resultante da relação dos contrários, que ao se opor dialeticamente, um } \\
\text { incluindo-se/excluindo-se no/do outro, se destroem ou se superam; as determinações } \\
\text { mais concretas contêm, superando-as, as determinações mais abstratas; assim, o } \\
\text { pensamento deverá mover-se durante o transcurso da investigação, entre os polos } \\
\text { dialeticamente relacionados [...] (p.65). }\end{array}$ \\
\hline Mediação & $\begin{array}{l}{[. . .] \text { cindindo o todo ao buscar a determinação mais simples do objeto de investigação, }} \\
\text { poder estudar o conjunto das relações que estabelece com os demais fenômenos e com } \\
\text { a totalidade; assim, buscar-se-á, por exemplo, entender o caráter mediador da } \\
\text { qualificação nas relações entre capital e trabalho. (p. 65). }\end{array}$ \\
Elaboração própria, a partir da obra de Kuenzer (2011)
\end{tabular}

Tal escolha deu-se para tentar explicar os movimentos que conduziram a formulação e a implementação da política. Nesse sentido, o ProUni foi analisado dialética e criticamente à luz de suas contradições e dos "interesses antagônicos implícitos aos discursos" (Sousa, 2014,p. 314) que lhe deram origem. O autor considera necessária essa análise ao definir o método "no campo da política e da gestão da educação" (p. 314), ou seja, os principais espaços ocupados pelo referido programa.

Acerca da categoria metodológica denominada totalidade, Sousa (2014) entende que “o conhecer científico começa pela parte, buscando o todo [...]. Compreende os fenômenos em suas várias dimensões e na perspectiva de sua historicidade, desvelando as contradições e mediações no contexto da totalidade na qual eles se manifestam" (p. 317). O Programa Universidade para Todos foi analisado a partir de uma instituição privada do Distrito Federal, 
como parte de um todo, identificado pelo processo de democratização do acesso à educação superior. Os limites da política foram analisados, considerando o contexto político e social do país, fazendo a relação entre a abstração da política e a concretude da realidade, como prevê o olhar dialético. Para uma melhor compreensão dessa perspectiva, Sousa (2014) explica que essa análise

[...] tem fundamento no pensamento marxista e pretende incorporar uma visão do objeto tal como este vai se revelando durante sua construção. Assim, essa abordagem constitui-se, ao mesmo tempo, em um método de investigação e um movimento de interpretação da transformação da própria realidade estudada (p. 331-332)

Analisar uma política à luz do que propõe um olhar dialético, pressupõe a superação da simples compreensão do fenômeno estudado. Parte-se do princípio de que o pesquisador pretende influenciar a realidade na qual está vinculado o objeto do estudo. No caso desta pesquisa, propor ideias que possam colaborar com os problemas de acesso e permanência de estudantes, historicamente excluídos, da educação superior no país. A partir dessa compreensão, Jesus (2014) destacou que os "trabalhos baseados na dinâmica do materialismo histórico $^{67 "}$ propõem demonstrar, dentre outras coisas, "as possibilidades e condições necessárias à superação da realidade vivenciada, a partir das próprias contradições inerentes a essa sociedade" (p. 232). Seguindo essa linha, o autor ressaltou o sentido da práxis, e explicou ser essa

[...] uma ação que significativamente, e ao mesmo tempo, conhece o objeto de estudo, compreende suas contradições e propõe alternativas que, não necessariamente, se constituem como um fim em si mesmas, mas permitem a ressignificação e a reconstrução de novas (p. 233).

Sendo assim, com o olhar dialético, proposto nesta pesquisa, se intencionou desvelar as contradições que os discursos divergentes dos grupos de interesses, entrevistados, revelam; e, assim, perceber os meandros e verdadeiros objetivos da política aqui abordada. Considerouse, ainda, a possibilidade de se propor medidas que pudessem contribuir, efetivamente, com o processo de democratização do acesso à educação superior, a fim de que aja uma incorporação eficaz dos grupos que compõem, majoritariamente, a sociedade brasileira, mas que ocupam, minoritariamente, os espaços educacionais.

\footnotetext{
${ }^{67}$ Nesta pesquisa, os termos materialismo histórico-dialético e método crítico-dialético assumem o mesmo significado, no entanto, o segundo é utilizado para definir o método de pesquisa educacional formulado por Sánchez Gamboa (2008).
} 
Ainda sobre as categorias do materialismo histórico-dialético, que contribuíram para nortear essa pesquisa, destaca-se a mediação, que cumpre o papel de mediar as ações entre homem e natureza, entre sujeito e objeto, pressupondo a capacidade de transformação, por meio da produção científica, que é resultante da ação humana sobre sua realidade e história. (SANCHES GAMBOA, 2012).

No caso específico do ProUni, a tensão existente na relação público-privada pressupõe uma contradição básica que é expressa por grupos, defensores da universidade pública e por aqueles que defendem o setor privado. Ambos representam interesses que vão além do objetivo final da política, que é, em tese, promover o acesso à educação superior aos grupos sociais historicamente alijados.

Outro aspecto considerado, ao optar por uma análise feita a partir de um olhar dialético, diz respeito à ênfase dada à historicidade dos fenômenos pesquisados. Considerando que o ProUni está em vigência há mais de dez anos, promover uma avaliação dos sujeitos envolvidos com o programa, contribuiu para identificar o caminho percorrido, segundo a perspectiva de cada um. Nesse sentido, Sanches Gamboa (2012) diz que

[...] o eixo condutor do método de investigação consiste na recuperação dos processos de construção dos fenômenos, e nesse processo as técnicas historiográficas ganham importância, já que permitem recuperar não apenas os contextos geográficos e espaciais, mas fundamentalmente, os processos de transformação dos fenômenos, sua origem e suas fases de evolução. A historiografia se torna indispensável para recuperar a historicidade e o devir histórico dos fenômenos (p. 153).

Essa análise corrobora com a decisão de imprimir uma perspectiva histórica ao fenômeno social pesquisado, por entender que não há possibilidade de análise, de qualquer movimento da sociedade, que esteja descontextualizado e apartado de suas dimensões econômicas, políticas e sociais. Além disso, o resgate histórico é o que proporciona o entendimento da realidade atual a partir dos acontecimentos e decisões pretéritas, as quais ainda impactam na trajetória e nos rumos do país.

Portanto, para conseguir responder ao objetivo geral desta pesquisa, assim como, seus objetivos específicos, foi realizada a triangulação das fontes dos dados. Isso significa fazer um cruzamento entre as informações fornecidas pelos entrevistados, pelos bolsistas e pelos documentos, a fim de que os resultados sejam revestidos de maior fidedignidade. Além disso, essa técnica, somada à compreensão do referencial bibliográfico, permite maior entendimento do tema pesquisado. Para explicar as vantagens dessa opção, Triviños (1987) observa que esta técnica 
[...] tem por objetivo básico abranger a máxima amplitude na descrição, explicação e compreensão do foco em estudo. Parte de princípios que sustentam que é impossível conceber a existência isolada de um fenômeno social, sem raízes históricas, sem significados culturais e sem vinculações estreitas e essenciais com uma macrorrealidade social. Tais suportes teóricos, complexos e amplos, não tornam fáceis os estudos qualitativos (p. 138).

O diálogo entre as fontes possibilita maior complementariedade das informações. Com o objetivo de ilustrar a técnica defendida por Triviños (1987), segue quadro que propõe facilitar sua compreensão, a partir do esquema por ele proposto.

\section{Quadro 4 - Modelo esquemático da técnica de triangulação na coleta de dados - Triviños $-1987$}

\begin{tabular}{|c|c|c|c|}
\hline \multirow{9}{*}{$\begin{array}{l}\text { Técnica da } \\
\text { triangulação }\end{array}$} & \multirow{4}{*}{$\begin{array}{c}\text { Processos e } \\
\text { produtos } \\
\text { centrados no } \\
\text { sujeito }\end{array}$} & \multicolumn{2}{|c|}{$\begin{array}{l}\text { Pelo pesquisador (percepções: entrevistas, questionários, } \\
\text { formas verbais; comportamentos e ações: observação livre). }\end{array}$} \\
\hline & & \multicolumn{2}{|c|}{$\begin{array}{l}\text { Pelo próprio sujeito(autobiografias, diários íntimos, } \\
\text { confissões, cartas pessoais, livros, obras de arte, composições } \\
\text { musicais, fotografias, etc. }\end{array}$} \\
\hline & & \multicolumn{2}{|c|}{ Documentos (internos e externos). } \\
\hline & & \multicolumn{2}{|c|}{$\begin{array}{l}\text { Instrumentos legais (leis, decretos, pareceres, resoluções, } \\
\text { regulamentos, regimentos). }\end{array}$} \\
\hline & \multirow{3}{*}{$\begin{array}{l}\text { Elementos } \\
\text { produzidos pelo } \\
\text { meio do sujeito }\end{array}$} & \multirow{3}{*}{ Oficiais } & $\begin{array}{l}\text { (diretrizes, propostas, memorandos, atas } \\
\text { de reuniões, políticas de ação etc.). }\end{array}$ \\
\hline & & & $\begin{array}{l}\text { Estatísticos }(\% \text { de analfabetismos, } \\
\text { evasão, repetência, relativas à escola } \\
\text { e/ou ao sistema escolar })\end{array}$ \\
\hline & & & Fotografias \\
\hline & \multirow{2}{*}{$\begin{array}{c}\text { Processos e } \\
\text { produtos } \\
\text { originados pela } \\
\text { estrutura } \\
\text { socioeconômica e } \\
\text { cultural do } \\
\text { macro- } \\
\text { organismo social } \\
\text { do sujeito }\end{array}$} & $\begin{array}{l}\text { Modos de } \\
\text { Produção }\end{array}$ & $\begin{array}{l}\text { Escravagismo } \\
\text { Feudalismo } \\
\text { Capitalismo (central, periférico, } \\
\text { dependente) } \\
\text { Socialismo }\end{array}$ \\
\hline & & \multicolumn{2}{|c|}{$\begin{array}{l}\text { Forças e relações de produção, propriedade dos meios de } \\
\text { produção e classes sociais (burguesia, média [pequena } \\
\text { burguesia], operária) }\end{array}$} \\
\hline
\end{tabular}

Fonte: Triviños (1987, p. 140) - adaptado pela autora.

No esquema apresentando, ficou evidente o entendimento do autor acerca da necessidade de inter-relacionar todas as informações coletadas na pesquisa. $O$ desenho apresenta a triangulação de informações concretas, como documentos (oficiais ou não), entrevistas, questionários, livros, fotografias etc., com dados abstratos fornecidos pela observação da realidade social (modos e meios de produção, classes sociais etc.). Sendo 
assim, esta pesquisa optou por utilizar a referida técnica, cruzando os dados coletados, com o objetivo de facilitar a compreensão do fenômeno pesquisado, qual seja: a capacidade do ProUni em promover a democratização do acesso, a partir da expansão da educação superior, no período proposto (2011-2015).

Além disso, a triangulação na coleta de dados, descrita por Triviños (1987), prevê que o sujeito está no centro de todas as fontes que serão cruzadas. São os "processos e produtos centrados no sujeito; os elementos produzidos pelo meio do sujeito e os processos e produtos originados pela estrutura socioeconômica e cultural do macroorganismo social do sujeito" (p. 140). Esse foco coaduna com o olhar dialético, proposto nesta pesquisa, a partir do materialismo histórico de Marx e Engels.

\subsection{A instituição pesquisada no cenário da educação superior privada do Distrito Federal}

Sobre o lócus dessa pesquisa, informa-se tratar de uma IES privada que ocupa um espaço relevante no cenário educacional do Distrito Federal. Pode-se dizer que está entre as maiores e mais importantes no contexto do setor privado local. Apresenta uma diversidade grande de cursos, em diferentes turnos e modalidades, incluindo a EaD. De acordo com as

publicações institucionais, sua missão é "atuar solidária e efetivamente para o desenvolvimento integral da pessoa humana e da sociedade, por meio da geração e comunhão do saber, comprometida com a qualidade, os valores éticos e cristãos, na busca da verdade" (IES, 2016).

Ressalta-se, no entanto, que não foi possível entrar em detalhes sobre a referida IES, devido ao comprometimento da pesquisadora com o Comitê de Ética em Pesquisa (CEP) da instituição, com o qual se formalizou o Parecer Consubstanciado $\mathrm{n}^{\circ}$ : 1.308 .815 , no qual recomendava a omissão do nome da instituição no relatório final da pesquisa. Todavia, seguem alguns dados publicados pelo Censo da Educação Superior 2014 (INEP, 2016) relativas a esta IES, como o número de cursos, matrículas e concluintes nas graduações presenciais e a distância em que corrobora com a afirmação feita anteriormente, sobre sua importância no contexto da oferta de educação superior do Distrito Federal. 
Tabela 7 - Número de concluintes, cursos e matrículas de graduação presencial e a distância da IES pesquisada - 2011 a $2014^{68}$

\begin{tabular}{|c|c|c|c|c|c|c|}
\hline $\begin{array}{c}\text { Ano } \\
\text { Modalidade } \\
\text { de ensino }\end{array}$ & \multicolumn{2}{|c|}{ Concluintes } & \multicolumn{2}{c|}{ Cursos } & \multicolumn{2}{c|}{ Matrículas } \\
\hline & $\begin{array}{c}\text { Graduação } \\
\text { Presencial }\end{array}$ & $\begin{array}{c}\text { Graduação } \\
\text { a Distância }\end{array}$ & $\begin{array}{c}\text { Gradução } \\
\text { Presencial }\end{array}$ & $\begin{array}{c}\text { Graduação } \\
\text { a Distância }\end{array}$ & $\begin{array}{c}\text { Gradução } \\
\text { Presencial }\end{array}$ & $\begin{array}{c}\text { Graduação } \\
\text { a Distância }\end{array}$ \\
\hline $\mathbf{2 0 1 1}$ & 2.186 & 2.023 & 46 & 15 & 16.326 & 4.401 \\
\hline $\mathbf{2 0 1 2}$ & 2.639 & 922 & 43 & 17 & 16.967 & 3.268 \\
\hline $\mathbf{2 0 1 3}$ & 2.613 & 607 & 42 & 18 & 16.020 & 3.164 \\
\hline $\mathbf{2 0 1 4}$ & 2.543 & 740 & 41 & 18 & 13.931 & 2.324 \\
\hline
\end{tabular}

Fonte: Sinopses Estatística da Educação Superior 2011, 2012, 2013 e 2014 (INEP, 2013;2014;2015; 2016)

Os dados apresentados indicam certa estabilidade entre os matriculados nos cursos presenciais no período de 2011 a 2013, girando em torno de dezesseis mil alunos. No entanto, em 2014, percebe-se uma redução de cerca de três mil matrículas, quando comparado ao ano de 2012. Já em relação à graduação a distância a queda foi estável durante todo o período abordado. Em 2011 havia 4.401 estudantes nessa modalidade, em 2012 (3.268), 2013 (3.164) e 2014 (2.324). Esse movimento de queda nas matrículas indica que, apesar de políticas como o ProUni promoverem a ampliação do acesso, a IES pesquisada passou por fenômeno inverso, no que diz respeito a suas matrículas em geral. O mesmo aconteceu com os números dos cursos oferecidos. A instituição tinha 46 cursos de graduação presenciais em 2011, caindo para 41 em 2014. Em relação à EaD foi o contrário, de 15 cursos no início do período em questão, passou a 18 em 2014. Ressalta-se, no entanto que, apesar do aumento no número de cursos, houve uma redução nas matrículas de $\mathrm{EaD}$, conforme aqui relatado.

Destaca-se, no entanto, que apesar da redução no número de matrículas e cursos (presencial) a quantidade de alunos que concluíram uma graduação cresceu durante o período, com exceção de 2014, comparada a 2013. Em 2011, 2.186 alunos terminaram seus estudos nessa IES. Já em 2012 esse número subiu para 2.639, em 2013 (2.613) e 2014 (2.543). Isso mostra que se manteve estável o número de concluintes, apesar das reduções apresentadas pelas matrículas. Esses dados mostram que, apesar das oscilações, a IES pesquisada apresenta números que ratificam sua importância no cenário da educação superior do DF.

\footnotetext{
${ }^{68}$ Não há dados relativos à 2015, pois o último censo da educação superior publicado foi o de 2014.
} 


\subsection{Caracterização dos sujeitos e dos cursos}

O Programa Universidade para Todos é uma ação do governo que objetiva promover o ingresso em instituições de educação superior, de pessoas de baixa renda, além de alcançar grupos historicamente alijados do acesso aos cursos de graduação, tais como os negros, indígenas e as pessoas com deficiência. Nesse sentido, para que fosse possível verificar a capacidade que essa política, até agora, teve de atingir seu objetivo, considerou-se necessário traçar o perfil dos bolsistas que compuseram esta pesquisa.

Além dos estudantes ${ }^{69}$ da IES selecionada, beneficiários do programa, outros sujeitos contribuíram para a compreensão do ProUni. Parte desse trabalho foi analisar a tensão existente entre os setores público e privado, no que diz respeito à oferta de vagas na educação superior. Sendo assim, considerou-se relevante ter acesso à percepção dos gestores no âmbito governamental e na esfera privada. Além desses, ressalta-se também o considerável papel das associações que defendem os interesses do setor privado. Sendo assim, julgou-se relevante, para esta pesquisa, ouvir o ponto de vista do representante de uma instituição que tem esse propósito. Assim, seria possível identificar as contradições presente nos diferentes discursos, tal como prevê um trabalho pautado pelo olhar histórico-dialético.

Em relação à escolha dos cursos, optou-se por fazer uma análise comparativa dos diferentes perfis, considerando demanda, custo e dificuldade acadêmica. É sabido que medicina e engenharia, desde as primeiras escolas superiores instaladas no Brasil, ainda no século XIX, sempre foram cursos direcionados à elite. (DURHAM, 2003; MINTO, 2006; SOUSA, 2013). Essa realidade perdurou e, ainda hoje, parte considerável dos ingressantes dessas graduações é de origem social mais abastada, com a reduzida presença de negros. Os pobres e os PPI (preto, pardo ou indígena) se fazem mais presentes nos cursos de licenciatura, conforme atestou Ristoff (2014).

Para mais detalhes dos cursos pesquisados, vale destacar que letras e administração figuraram entre os dez com maior número de matrículas em 2012. Com 1.325.374 matrículas, o curso de administração ocupou o topo da lista, seguido por engenharia, com 802.454, o que correspondeu a $18,8 \%$ e $11,4 \%$, respectivamente, do total de matrículas naquele ano. O curso de letras, com 181.007 matriculados, ficou em $10^{\circ}$ lugar, com 2,6\%. (GRIBOSKI, 2014).

\footnotetext{
${ }^{69}$ Os estudantes, bolsistas, que participaram desta pesquisa, responderam a um questionário com questões de múltipla escolha e intervalares. Além dessas, foi apresentada a eles uma questão "aberta" para que fizessem críticas ou sugestões ao Programa. A identificação dos estudantes foi feita com a letra B (de bolsista), seguida por numeração sequencial, exemplo: B1, B2, B3, etc.
} 
Segundo a autora, “a expansão da educação superior tem sido demonstrada nos dez maiores cursos de graduação ofertados pelo sistema educacional brasileiro" (p.215). Nesse sentido, a escolha para esta pesquisa justifica-se pela importância que ocupam no cenário da educação superior do país, considerando não só o número de matrículas, mas também o perfil socioeconômico diversificado dos estudantes que os frequentam.

\subsubsection{Perfil dos beneficiários no contexto dos cursos pesquisados}

Os quatro cursos selecionados para compor esta pesquisa, podem ser divididos em dois grupos. O primeiro, formado por Medicina e Engenharia Civil, e o segundo, por Administração e Letras. Aqueles fazem parte de um grupo que, historicamente, sempre foi frequentado por estudantes de uma classe econômica mais abastada e com presença majoritária de brancos. Em relação ao segundo grupo, cabe explicar, como já abordado, que o curso de Administração foi escolhido por sua relevância junto ao número de matrículas, figurando entre os mais procurados; e o curso de Letras, apesar de também marcar presença na lista dos 10 cursos com maior número de estudantes matriculados (GRIBOSKI, 2015), foi escolhido por ser uma licenciatura. Pesquisas revelam que essa modalidade de curso é mais demandada por pessoas de renda mais baixa.

A necessidade de confrontar cursos de perfis tão diferentes, se deu numa tentativa de analisar o quanto o ProUni está proporcionando o ingresso de pessoas pobres e negras em cursos antes frequentados, em sua maioria, por brancos e ricos. Além disso, ao escolher cursos com grande representatividade em termos de matrículas, como Administração e Letras, intencionou-se identificar se o programa contribui para a democratização do acesso à educação superior, conforme previsto na lei do ProUni, garantindo a presença de estudantes de baixa renda, assim como, de negros, indígenas e pessoas com deficiência. O quadro a seguir traz a quantidade de bolsistas, por curso pesquisado, que responderam ao questionário.

\section{Quadro 5 - Curso do bolsista - 2016}

\begin{tabular}{c|c|c}
\hline Curso superior & Frequência & Percentual \\
\hline Administração & 17 & 25,8 \\
\hline Engenharia Civil & 30 & 45,5 \\
\hline Letras & 9 & 13,6 \\
\hline Medicina & 10 & 15,1 \\
\hline Total & 66 & 100,0 \\
\hline
\end{tabular}

Fonte: Elaborado pela autora. 
Da lista de 1004 e-mails fornecida pela IES, dos bolsistas que compunham o recorte desta pesquisa, apenas 226 eram válidos, desses, 66 (29,20\%) responderam ao questionário. Dentre os que participaram, vê-se que a maioria deles é do curso de Engenharia Civil, com $45,5 \%$, seguido pelo de Administração $(25,8 \%)$, Medicina $(15,1 \%)$ e, por último, Letras $(13,6 \%)$. Do total dessa amostra, $92,4 \%$ são solteiros, sendo $56 \%$ do sexo feminino. Outro dado importante diz respeito à idade desses bolsistas. A maioria $(66,6 \%)$ tem entre 18 e 24 anos, ou seja, dentro da faixa etária, considerada ideal para cursarem uma graduação.

A soma da quantidade de bolsistas que utilizaram o critério de ação afirmativa prevista na lei do ProUni, como cota étnico-racial e reserva de vagas para pessoas com deficiência foi bastante equilibrada, quando comparado ao número de estudantes que não utilizaram, conforme quadro a seguir.

Quadro 6 - Ingresso de bolsistas pelo critério de políticas afirmativas - 2016

\begin{tabular}{l|c|c}
\multicolumn{1}{c|}{ Resposta } & Frequência & Percentual \\
\hline Não utilizou & 36 & 54,5 \\
\hline Étnico-racial* & 29 & 43,9 \\
\hline Portador de deficiência & 1 & 1,5 \\
\hline Total & 66 & 100,0 \\
\hline
\end{tabular}

Fonte: Elaborado pela autora.

* Pretos, pardos ou indígenas.

Vê-se que 43,9\% dos bolsistas que responderam ao questionário utilizaram a reserva de cotas para negros e indígenas, como critério para conseguir a bolsa do ProUni e, consequentemente, ingressar na instituição de educação superior. Com esse dado, é possível inferir que o programa promove maior diversidade no corpo discente, na IES e nos cursos. Para corroborar com essa afirmação, segue dados relativos ao perfil, segundo cor/raça do bolsista. 
Quadro 7 - Distribuição dos bolsistas segundo cor/raça - 2016

\begin{tabular}{l|c|c}
\multicolumn{1}{c|}{ Cor/Raça } & Frequência & Percentual \\
\hline Amarelo(a) & 1 & 1,5 \\
\hline Branco(a) & 17 & 25,8 \\
\hline Pardo(a) & 41 & 62,1 \\
\hline Preto(a) & 6 & 9,1 \\
\hline NR* & 1 & 1,5 \\
\hline Total & 66 & 100,0 \\
\hline
\end{tabular}

Fonte: Elaborado pela autora; *NR = Não respondeu

Conforme descrito no quadro $7,62,1 \%$ se autodenominaram pardos, $9,1 \%$ pretos e $25,8 \%$ brancos. Esses dados revelam que essa distribuição difere-se daquela identificada no âmbito da população brasileira, em que a maioria é representada pela cor branca, com $45,5 \%$ do total, seguida pela parda, $45,0 \%$ e preta, $8,6 \%$. Isso demonstra que, de alguma forma, o ProUni está promovendo a democratização do acesso (entendida como inclusão de diferentes grupos raciais) à educação superior, já que as bolsas estão sendo usufruídas, em sua maioria, por negros (pretos e pardos), representado por $71,2 \%$ dos bolsistas.

A reserva de cota étnico-racial, prevista na lei do ProUni, é um critério que compõe as ações afirmativas, cujo objetivo é contribuir para a inclusão de grupos tradicionalmente excluídos do acesso à educação superior. No entanto, essa política define como principal critério para conseguir uma bolsa, integral ou parcial, a renda familiar per capita do estudante, pois, de acordo com o discurso oficial, o objetivo principal do programa é possibilitar que pessoas pobres possam cursar uma graduação e, consequentemente, promover um impacto socioeconômico na vida do estudante e de sua família. Sendo assim, fez-se necessário, nesta pesquisa, traçar o perfil, segundo critério de renda, para que fosse possível observar o quanto estão sendo atendidas as regras estabelecidas pelo programa.

Para caracterizar a condição socioeconômica do bolsista, quatro perguntas foram feitas: a) Você tem renda própria?; b) Qual o valor de sua renda mensal?; c) Quantas pessoas têm renda em sua casa? e d) Somando a sua renda (se tiver), com a das demais pessoas que moram com você, quanto é, aproximadamente, a renda familiar? (Considere a renda de todos os integrantes que moram com você). Ao analisar a respostas, perceberam-se algumas inconsistências que podem ter sido causadas por erro de interpretação do respondente. Dentre os 66 bolsistas, 38 (57,6\%) responderam não ter renda; e 27 (40,9\%) disseram ter receita própria. Entretanto, na pergunta seguinte (sobre o valor da renda própria 
mensal do bolsista) notou-se que 44 estudantes marcaram alguma resposta, dentre as disponíveis, conforme tabela a seguir.

Tabela 8 - Distribuição dos bolsistas segundo valor de sua renda ${ }^{1}$ própria - 2016

\begin{tabular}{|c|c|c|}
\hline Resposta & Frequência & Percentual \\
\hline De $R \$ 1.321,00$ a $R \$ 1.760,00$ & 3 & 4,5 \\
\hline De $R \$ 2.201,00$ a $R \$ 2.640,00$ & 1 & 1,5 \\
\hline De $\mathrm{R} \$ 2.641,00$ a $\mathrm{R} \$ 3.080,00$ & 2 & 3,0 \\
\hline De $R \$ 3.081$ a $R \$ 3.520,00$ & 1 & 1,5 \\
\hline De $\mathrm{R} \$ 3.521,00$ a $\mathrm{R} \$ 3.960,00$ & 1 & 1,5 \\
\hline De $\mathrm{R} \$ 881,00$ a $\mathrm{R} \$ 1.320,00$ & 13 & 19,7 \\
\hline Menos de $\mathrm{R} \$ 880,00$ & 23 & 34,8 \\
\hline$* \mathrm{NR}$ & 22 & 33,3 \\
\hline Total & 66 & 100,0 \\
\hline
\end{tabular}

Fonte: Elaborado pela autora; $* \mathrm{NR}=$ Não respondeu.

${ }^{1}$ Valor de referência: salário mínimo (Decreto no 8.618 de 29/12/2015)

Nesse sentido, pode-se inferir que alguns alunos que compõem o grupo dos que ganham menos de $\mathrm{R} \$ 880,00$ não consideram como renda os valores percebidos. Como hipótese, pode-se considerar esse ganho como algum tipo de mesada ou algo do gênero, configurado como renda. Nesse sentido, percebe-se que apenas $12 \%$ ganham mais de um salário mínimo e meio. O outro grupo $(19,7 \%)$ ganha entre um e um salário mínimo e meio, seguido daqueles que ganham menos de um salário mínimo (34,8\%). Esse quadro demonstra duas coisas: (i) que a maioria dos alunos com renda atendem à condição exigida pelo ProUni; e que (ii) 7,5\% desses alunos ultrapassam a renda per capita definida pelo programa. No entanto, isso não pode ser considerado uma violação do critério de exigibilidade, pois esse aluno pode ser o único a ter renda, em uma família com três, quatro ou cinco integrantes. Afinal, o critério de renda diz respeito ao valor per capita ${ }^{70}$ (por membro da família), e não ao valor bruto da renda familiar.

A tabela a seguir mostra que, somada a do bolsista, a renda familiar mais representativa está no grupo dos que ganham entre um e um salário mínimo e meio $(25,8 \%)$. Traduzindo em valores, isso significa, de $\mathrm{R} \$ 880,00$ a $\mathrm{R} \$ 1$. 320,00. O outro grupo com maior

\footnotetext{
${ }^{70}$ A renda familiar por pessoa (ou per capita) é calculada somando-se a renda bruta dos componentes do grupo familiar dividindo-se pelo número de pessoas que formam este grupo familiar. Ainda, de acordo com explicações do MEC (2016), considera-se como grupo familiar "a unidade nuclear composta por uma ou mais pessoas, eventualmente que contribuam para o rendimento, ou tenham suas despesas atendidas por aquela unidade familiar, todas moradoras em um mesmo domicílio".
} 
representatividade $(15,2 \%)$ tem renda familiar entre $\mathrm{R} \$ 1.321,00$ e $\mathrm{R} \$ 1.760,00$, ou seja, de um e meio a dois salários mínimos, seguido por aqueles $(12,1 \%)$, cuja renda fica entre dois e dois salários mínimos e meio ( $\mathrm{R} \$ 1.760,00$ a $\mathrm{R}$ \$2.200,00), conforme ilustrado na tabela.

Tabela 9 - Distribuição dos bolsistas segundo a renda familiar - 2016

\begin{tabular}{|c|c|c|}
\hline Resposta & Frequência & Percentual \\
\hline Acima de $\mathrm{R} \$ 4.401,00$ & 3 & 4,5 \\
\hline De $R \$ 1.321,00$ a $R \$ 1.760,00$ & 10 & 15,2 \\
\hline De $R \$ 1.761,00$ a $R \$ 2.200,00$ & 8 & 12,1 \\
\hline De $R \$ 2.201,00$ a $R \$ 2.640,00$ & 4 & 6,1 \\
\hline De $R \$ 2.641,00$ a $R \$ 3.080,00$ & 4 & 6,1 \\
\hline De $\mathrm{R} \$ 3.081$ a $\mathrm{R} \$ 3.520,00$ & 5 & 7,6 \\
\hline De $R \$ 3.521,00$ a $R \$ 3.960,00$ & 1 & 1,5 \\
\hline De $R \$ 3.961,00$ a $R \$ 4.400,00$ & 4 & 6,1 \\
\hline De $\mathrm{R} \$ 881,00$ a $\mathrm{R} \$ 1.320,00$ & 17 & 25,8 \\
\hline Menos de $\mathrm{R} \$ 880,00$ & 3 & 4,5 \\
\hline $\mathrm{NR}^{*}$ & 6 & 9,1 \\
\hline $\mathrm{RI}^{* *}$ & 1 & 1,5 \\
\hline Total & 66 & 100,0 \\
\hline
\end{tabular}

Fonte: Elaborado pela autora; *NR = Não respondeu; **RI = Resposta Invalidada.

Essas informações ratificam o caráter social do programa ao priorizar famílias de baixa renda. No entanto, vale destacar que as informações devem ser comprovadas sob o risco de terem as bolsas canceladas quando descoberta alguma omissão de renda ou, ainda, no caso de incompatibilidade entre algum bem material do bolsista (tipo de automóvel, por exemplo) e a renda declarada ${ }^{71}$.

Percebe-se nessa tabela que seis estudantes não responderam à questão, ou seja, 9,1\% dos bolsistas. A partir desse dado, pode-se inferir que o discente sinta insegurança em informar o rendimento de sua família por temer o cancelamento de seu benefício. O critério de renda é condição sine qua non para concorrer a uma bolsa do ProUni ${ }^{72}$. Caso se descubra

\footnotetext{
${ }^{71}$ Essa situação foi relatada em Ata de reunião da COLAP (Comissão Local de Acompanhamento e Controle Social do ProUni), realizada pela instituição pesquisada. Em 2013 houve o caso de uma estudante que teve a bolsa encerrada por ter omitido informação e documentação relativa à fonte de renda da mãe. Em outro caso, foi observada a incoerência entre um bem automobilístico (Hillux) da família e a renda familiar apresentada pelo bolsista. Essa situação também foi registrada em ata de reunião da COLAP. Disso, se depreende a importância que essas comissões têm para um eficaz acompanhamento social do Programa.

72 Com exceção do professor de educação básica, da escola pública que, independentemente da renda, pode concorrer a uma bolsa do ProUni. Conforme o art. $2^{\circ}$ da Lei $n^{\circ} 11.096$ de 2005, a bolsa será concedida à
} 
que o valor da renda familiar per capita ultrapasse o que é estabelecido em lei, a instituição tem de desligá-lo do programa.

Ao analisar o gráfico que se segue, o qual traz a quantidade de pessoas que têm renda e moram na casa do bolsista, vê-se que a maioria $(63,6 \%)$ é composta por um ou dois integrantes nessa condição. Desses, 33,3\% das casas é composta por apenas um com renda. A família que tem de três a quatro indivíduos com rendimento próprio é representada por 24,2\% dos bolsistas. Na sequência, têm-se as famílias compostas por cinco pessoas $(4,5 \%)$ e seis (3,0\%), com renda própria. Depreende-se daí que a maior parte dos bolsistas são seus próprios provedores ou contam apenas com o pai ou a mãe para manter o sustento da família.

\section{Gráfico 10 - Distribuição de pessoas com renda própria na casa do bolsista - 2016}

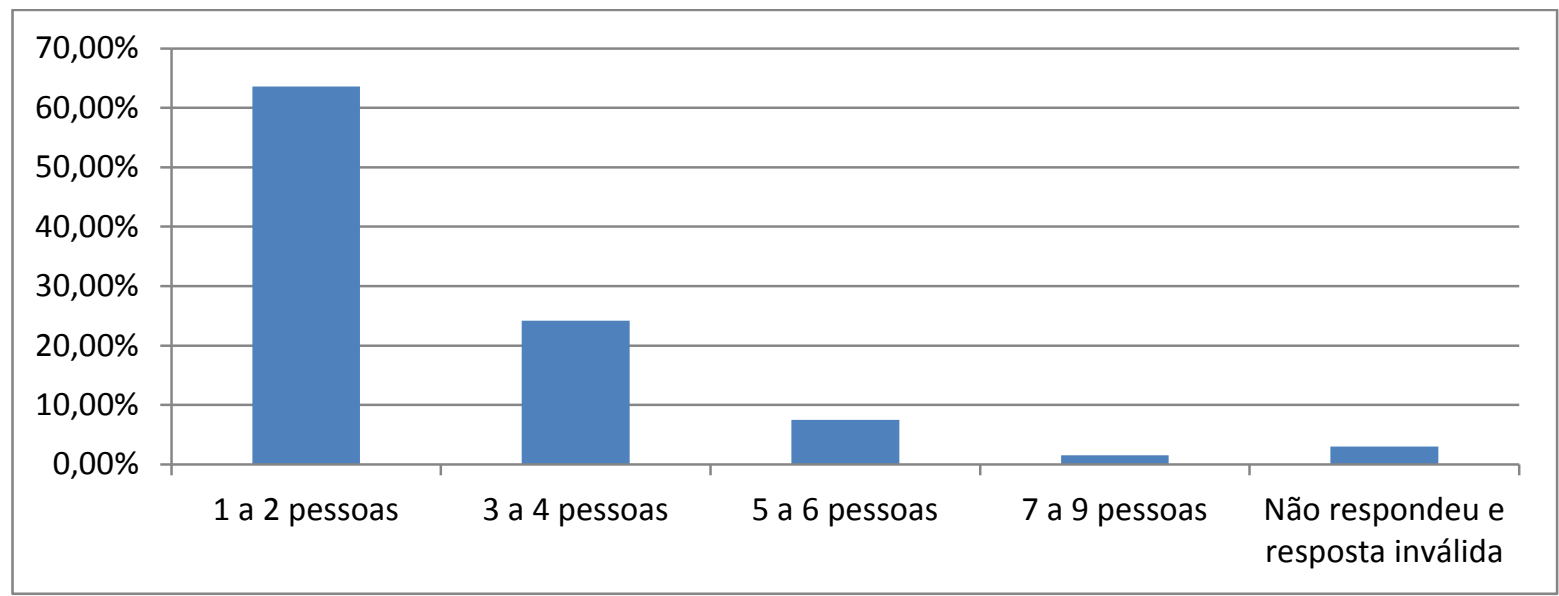

Fonte: elaborado pela autora.

Outro dado importante para conhecer o perfil socioeconômico do bolsista do ProUni que compôs a amostra desta pesquisa diz respeito ao nível de escolaridade dos pais. Pesquisas mostram que quanto maior a escolarização da mãe e do pai, melhor é o desempenho dos estudantes, conforme atesta o Enade. Além disso, cursos elitizados, como Medicina, são frequentados, tradicionalmente, por discentes com pais com mais tempo de estudo (ABRAES, 2014; RISTOFF, 2014). O estudo da Associação Brasileira para o Desenvolvimento da Educação Superior - Abraes (2014) mostrou que bolsistas do ProUni têm pais com menos escolaridade que a média de educandos de IES públicas e privadas.

A quantidade de anos de estudo, dos pais dos bolsistas que integraram este trabalho corrobora com o levantamento feito pela referida associação. Conforme demonstrado no 
gráfico 11 , a seguir, 39,4\% têm apenas o ensino fundamental e 25,8\%, o ensino médio. Dentre os que têm formação superior, apenas 18,2\% concluíram uma graduação.

\section{Gráfico 11 - Distribuição quantitativa do nível de escolaridade do pai - 2016}

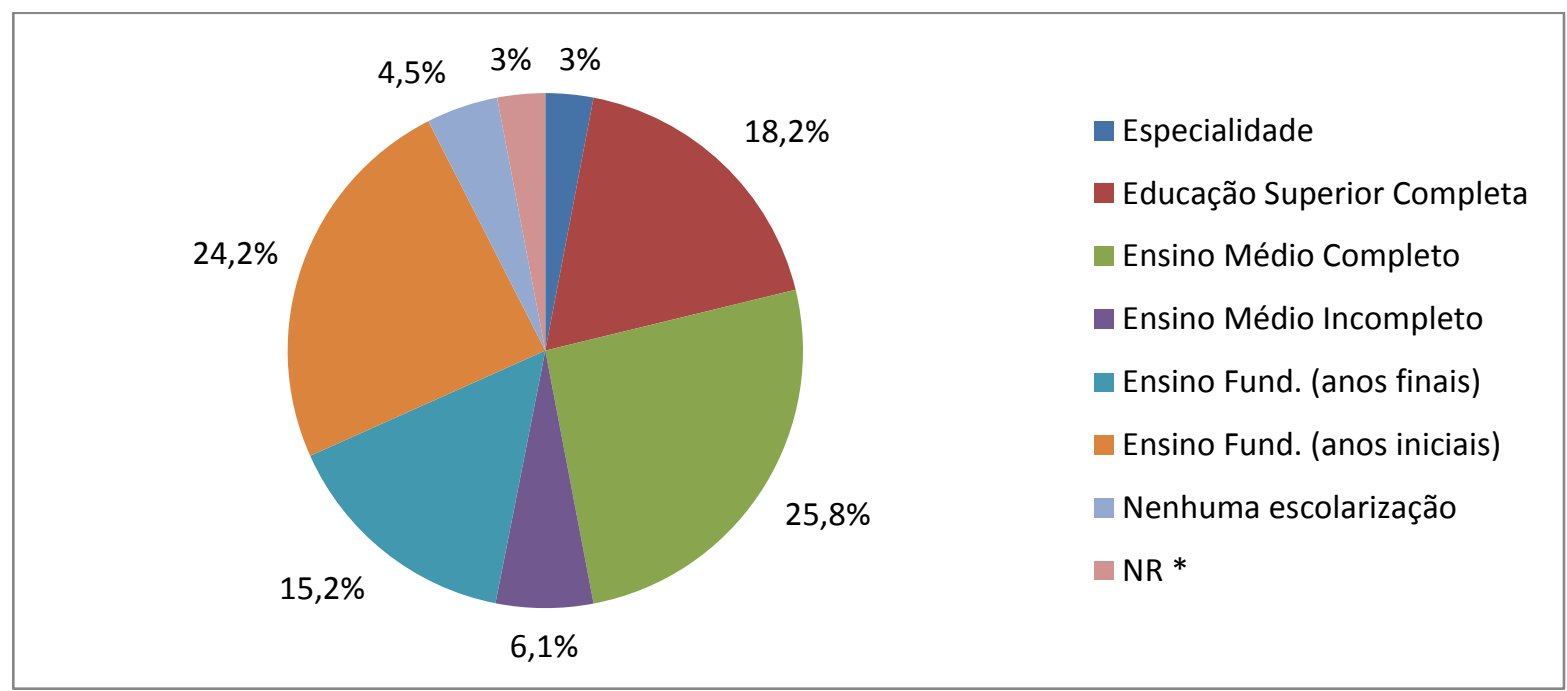

Elaborado pela autora; $*$ NR $=$ Não respondeu

Como se pode observar no gráfico, $4,50 \%$ dos pais e 3,00\% das mães não têm nenhuma escolaridade. E, especificamente em relação às mães dos bolsistas, tem-se que $12,10 \%$ fizeram apenas o ensino fundamental e $9,10 \%$ o tem incompleto. A maioria é representada por aquelas com o ensino médio completo (36,40\%). Quanto à educação superior, 12,10\% das mães têm curso de graduação concluído. Esses dados corroboram a indicação de alguns estudos, de que a baixa escolaridade dos filhos tem relação direta com a dos pais. Significa dizer que, pais formados tendem a exigir que seus filhos também estudem para conquistar uma formação. Pesquisas relevam que a relação entre educação dos pais e dos filhos é diretamente proporcional (ABRAES, 2014; RISTOFF, 2014).

Nesse sentido, o ProUni reverte um pouco essa lógica ao promover a inserção de jovens na educação superior, transformando-o no primeiro membro da família a conquistar um diploma desse nível educacional. Ainda sim, a realidade concreta é a de que o país tem dívidas históricas com sua população ao ter permitido que exista pessoas que nunca sentaram num banco escolar, figurando no perverso quadro dos analfabetos.

A discussão ideológica acerca do papel do Estado em relação às políticas educacionais não deveriam sequer existir. Concretamente falando, é preciso encarar os déficits estruturais na educação do país - em todos os níveis - e, a partir desse diagnóstico, diversificar os programas de modo a alcançar todos os públicos. Assim, acredita-se ser 
possível promover a democratização do acesso à educação, não só superior, mas, como visto nesses gráficos, em todos os demais níveis. Fora isso, o resto é pura retórica.

\section{Gráfico 12 - Distribuição percentual do nível de escolaridade da mãe - 2016}

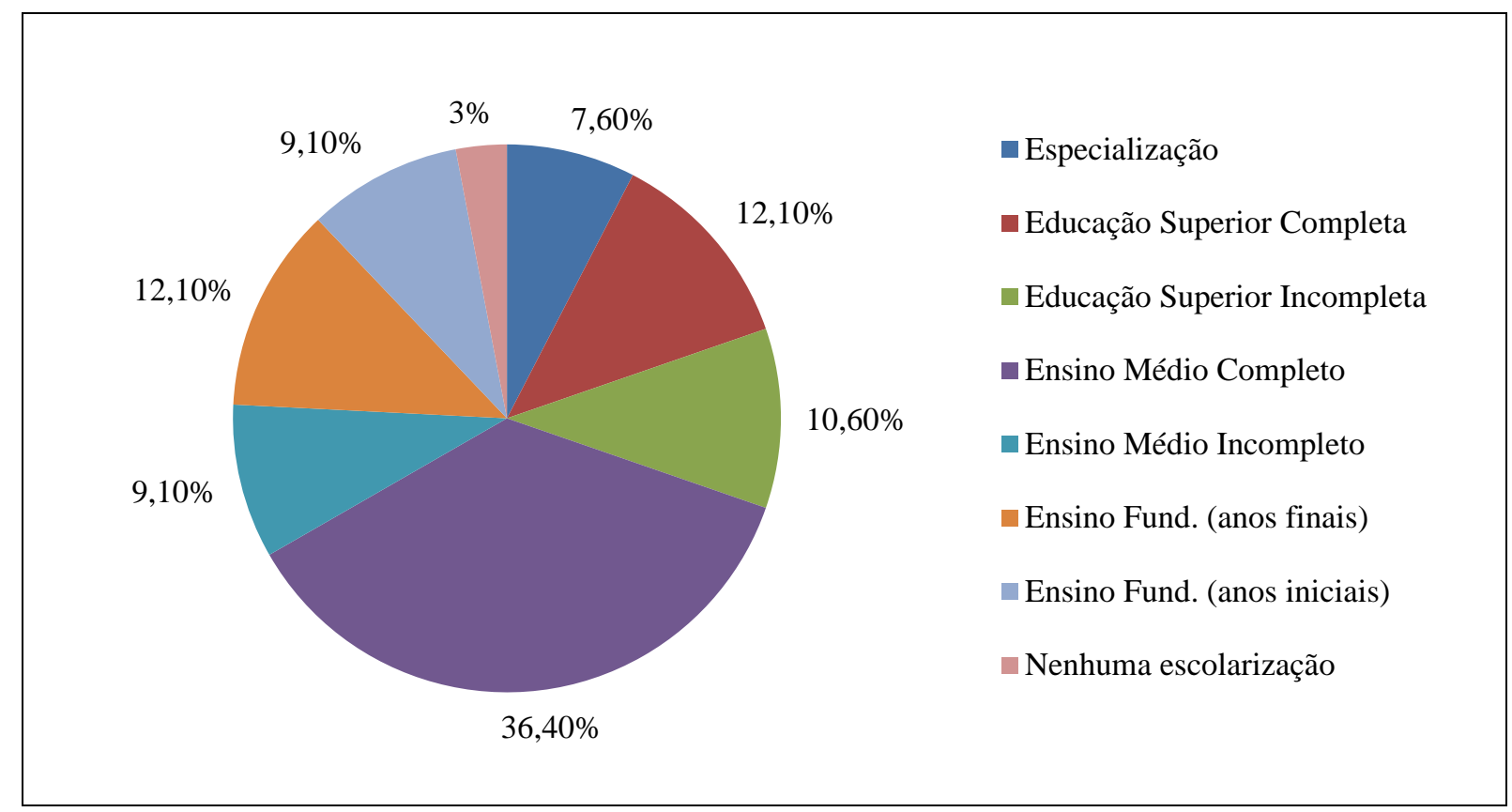

Fonte: Elaborado pela autora;

* NR= Não respondeu

Esses dados confirmam que o nível de escolaridade, tanto dos pais quanto das mães dos bolsistas, concentra-se entre o ensino fundamental e o ensino médio. Isso corrobora o discurso de defensores do programa, de que o ProUni, muitas vezes, contribui para que uma família tenha a primeira geração cursando uma graduação. Como consequência desse fenômeno, o gestor do Ministério da Educação, entrevistado, destacou outro movimento, o qual chamou de "revolução silenciosa". Segundo ele, o programa impacta nas gerações futuras, ao afirmar que "o filho do pai analfabeto que chegou à educação superior e que nunca vai aceitar que seu filho não vá pra educação superior, então o nível de exigência dele aumenta, esse que é o bonito" (GM1 - informação verbal).

Quanto ao ingresso dos bolsistas que responderam ao questionário desta pesquisa, o recorte inicial seria de 2013 a 2015, no entanto, alguns estudantes enviaram e-mail dizendo que não havia a opção referente ao ano de ingresso deles. Sendo assim, decidiu-se ampliar as possibilidades de resposta e os anos de 2011 e 2012 foram incluídos. A seguir, a tabela referente ao período em que os estudantes ingressaram na instituição de educação superior como beneficiários do programa. 
Tabela 10 - Distribuição de ingressantes por processo seletivo - 2011 a 2015

\begin{tabular}{|c|c|c|}
\hline Período de ingresso & Frequência & Percentual \\
\hline $1^{\circ}$ Semestre de 2011 & 1 & 1,5 \\
\hline $2^{\text {o }}$ Semestre de 2011 & 2 & 3,0 \\
\hline $1^{\circ}$ Semestre de 2012 & 3 & 4,5 \\
\hline $2^{\text {o }}$ Semestre de 2012 & 5 & 7,6 \\
\hline $1^{\circ}$ Semestre de 2013 & 10 & 15,2 \\
\hline $2^{\circ}$ Semestre de 2013 & 8 & 12,1 \\
\hline $1^{\circ}$ Semestre de 2014 & 11 & 16,7 \\
\hline $2^{\circ}$ Semestre de 2014 & 8 & 12,1 \\
\hline $1^{\circ}$ Semestre de 2015 & 5 & 7,6 \\
\hline $2^{\circ}$ Semestre de 2015 & 12 & 18,2 \\
\hline NR* & 1 & 1,5 \\
\hline Total & 66 & 100,0 \\
\hline
\end{tabular}

Fonte: Elaborado pela autora;

*NR = Não respondeu.

Dentre os respondentes, a maior parte ingressou entre 2013 e 2015 (81,9\%). Isso pode ser explicado pelo fato de a solicitação junto à IES, para informar os contatos dos alunos, ter sido feita com o recorte daquele período. Em relação aos cursos, vale destacar o número de bolsas que foram ofertadas pela instituição corpus desta pesquisa no recorte temporal pesquisado (2011-2015), conforme tabela, a seguir.

Tabela 11 - Distribuição de bolsas por curso pesquisado - 2011 a 2015

(continua)

\begin{tabular}{|c|c|c|c|}
\hline Ano & Curso & Número de bolsas & $\begin{array}{c}\text { Total por ano, nos cursos } \\
\text { pesquisados }\end{array}$ \\
\hline \multirow[t]{4}{*}{2011} & Administração & 45 & \multirow[t]{4}{*}{110} \\
\hline & Engenharia Civil & 27 & \\
\hline & Letras (português e inglês) & 27 & \\
\hline & Medicina & 11 & \\
\hline \multirow[t]{4}{*}{$2012^{73}$} & Administração & 16 & \multirow[t]{4}{*}{37} \\
\hline & Engenharia Civil & 15 & \\
\hline & Letras (português e inglês) & 5 & \\
\hline & Medicina & 1 & \\
\hline
\end{tabular}

\footnotetext{
${ }^{73}$ Não foi localizado o quadro referente à oferta de bolsas do $2^{\circ}$ semestre de 2012 , portanto não há como garantir se houve ou não oferta nesse período.
} 
Tabela 11 - Distribuição de bolsas por curso pesquisado - 2011 a 2015

(conclusão)

\begin{tabular}{|c|c|c|c|}
\hline Ano & Curso & Número de bolsas & $\begin{array}{c}\text { Total por ano, nos cursos } \\
\text { pesquisados }\end{array}$ \\
\hline \multirow{4}{*}{2013} & Administração & 20 & \multirow{4}{*}{75} \\
\hline & Engenharia Civil & 20 & \\
\hline & Letras (português e inglês) & 20 & \\
\hline & Medicina & 15 & \\
\hline \multirow{4}{*}{2014} & Administração & 18 & \multirow{4}{*}{99} \\
\hline & Engenharia Civil & 45 & \\
\hline & Letras (português e inglês) & 23 & \\
\hline & Medicina & 13 & \\
\hline \multirow{4}{*}{2015} & Administração & 11 & \multirow{4}{*}{65} \\
\hline & Engenharia Civil & 22 & \\
\hline & Letras (português e inglês) & 24 & \\
\hline & Medicina & 8 & \\
\hline
\end{tabular}

Elaborado pela autora. Dados: IES

As bolsas ofertadas, descritas nessa tabela, são integrais (100\%), e contemplam cursos presenciais distribuídos em todos os turnos. Percebe-se, nesses dados, que 2011 e 2014 foram os anos que apresentaram maior oferta, comparado aos demais, aqui abordados. Como a lei do ProUni prevê que o número de bolsas deve, obrigatoriamente, ser proporcional ao número de pagantes (uma para cada 10,7 alunos), depreende-se que a instituição ofertou menos vagas, para o público geram, nos anos de 2012, 2013 e 2015. Outro dado que pode ser observado nesse quadro tem a ver com o curso de engenharia civil. O significativo aumento no número de bolsas ofertadas em 2014 pode ser atribuído à demanda por profissionais da área de infraestrutura, cuja carência foi bastante destacada nos últimos anos, devido ao crescimento econômico da década passada.

Ao aderir ao ProUni, a IES deve ofertar bolsas em todos os cursos e turnos. Isso contribui para a democratização do acesso à educação superior, sobretudo, ao permitir que bolsistas ingressem em cursos de alto custo e demanda, como medicina e engenharia. De acordo com a tabela, entre 2011 e 2015, 386 bolsas foram ofertadas, na IES em questão. Aos que queriam se tornar médico ou engenheiros, foram disponibilizadas 167 no total. Conforme relatou um gestor do MEC, entrevistado, há "histórias emocionantes" de bolsistas, filhos de 
pessoas analfabetas, que moram no interior do país, e se tornaram médicos, graças ao programa.

O caráter democratizante desta política está presente em outro fator de elegibilidade. Além da renda, o estudante deve ser egresso da escola pública ou da escola privada na condição de bolsista integral. Esse critério, além de priorizar as pessoas de baixa renda, contribui, de alguma forma, para a valorização da rede pública de ensino. Segundo o gestor do MEC, "o princípio do ProUni de fortalecer a escola pública, valorizar o aluno vindo da escola pública tá correto" (GM1, informação verbal). No entanto, ao ser questionado em relação ao fato de o aluno ter estudado, em algum momento de sua vida, na rede privada (sem ser na condição de bolsista, mas, por exemplo, com a mensalidade paga por algum parente distante) dever mesmo ser impedimento para concorrer a uma bolsa do programa, ele discordou. Conforme observou, "nós já não precisamos nos preocupar tanto com isso, porque hoje nós abrimos tantas oportunidades, também no setor público - tanto nas federais, quanto nos institutos - por que você vai excluir um ou outro?" (GM1, informação verbal). O gestor em questão considera essa discussão insignificante dentro do todo; segundo ele, "desde que comprove que está em situação de carência" (GM1, informação verbal) esse aluno deveria poder concorrer à bolsa.

Sobre o critério de origem escolar, o perfil do bolsista que participou dessa pesquisa fez o ensino médio, majoritariamente, na escola pública (81,8\%). Outros 12,1\%, integralmente, na rede privada com bolsa integral; e os demais $(3,0 \%)$, parcialmente em escola pública e privada, na condição de bolsista. Esses dados confirmam o alcance do programa em relação aos egressos do ensino gratuito e público e favorece o fortalecimento do mesmo, contribuindo, inclusive, para um movimento de retorno de alunos da escola privada para a pública, a fim de se poder concorrer aos programas que privilegiam os estudantes dessa última. Afinal, além do ProUni, existem outras iniciativas, como a lei de cotas e reserva de vagas definidas pelas próprias universidades federais. Contudo, embora haja políticas públicas que contribuam para o ingresso de estudantes nas IES, isso não é garantia de que ele continuará seus estudos até o fim.

A situação de carência do bolsista permanece após seu ingresso na IES, e essa fragilidade econômica acarreta dificuldades para o desenvolvimento do curso. Muitas vezes, o bolsista não tem como adquirir materiais necessários à realização de determinadas disciplinas. Diante dessa constatação, foi criada a bolsa permanência, para auxiliar, financeiramente, esse discente. $\mathrm{O}$ benefício tem como objetivo custear as "despesas educacionais de beneficiário de bolsa integral do Programa Universidade para Todos - ProUni” (BRASIL, 2011). No entanto, 
essa ajuda financeira alcança poucos bolsistas, ademais, é considerada insuficiente em termos de valor (em 2015 a bolsa era de $\mathrm{R} \$ 400,00$ ).

Uma gestora do MEC/Inep, entrevistada, reconheceu esse problema ao reafirmar a importância da ajuda financeira para a permanência do bolsista na instituição e destacou que a abrangência do programa deveria ser bem maior, assim como seu valor. Segundo ela, é

[...] extremamente necessário. Eu acho que pra todos os cursos, porque se ele é um estudante que já ingressa por uma política afirmativa é porque é um aluno que precisa. Então, a chance dele desistir ou parar no meio do caminho por falta de bolsa permanência é enorme. Então, se ele não tiver esse apoio, não tiver a bolsa permanência, dificilmente ele vai poder continuar. [...] A gente avançou muito com as políticas de acesso e pouco com a política de permanência. $\mathrm{O}$ valor é muito pequeno e quando há disponível na instituição. [...] não adianta você promover o acesso se você não garantir a qualidade (GM2 - informação verbal).

Em relação aos bolsistas que compõem esta pesquisa, apenas 25,8\% disseram receber o benefício. Entre os que não recebem, são 72,7\%, ou seja, a grande maioria não tem o benefício. E 1,5\% disse usufruir de outro tipo de bolsa, oferecida por órgão governamental. Alguns bolsistas, ao responderem à questão aberta, (com crítica ou sugestão ao programa), destacaram o tema relativo à bolsa permanência. Um deles fez ressalva ao valor do auxílio, além de seu reduzido alcance. Segundo o estudante, "a bolsa permanência é muito pequena e só é ofertada para alunos de cursos integrais, sendo que todos os outros cursos também têm custos com materiais, visitas técnicas, alimentação dos alunos, etc.” (B18, informação verbal). Para esse outro estudante, a crítica foi a seguinte:

[...] o que estraga o Prouni é a falta de compromisso em relação à bolsa permanência. Tem vários alunos que se mantém através dessa bolsa, pagam aluguel, água, luz e alimentação. Todos os meses vejo o desespero deles no grupo do Prouni e ligo para o MEC para saber quando sai a bolsa. O valor da bolsa também não ajuda quem está longe de casa, passar o mês com $\mathrm{R} \$ 400,00$ deve ser bem difícil. (B20, informação verbal).

Por fim, esse bolsista demonstrou preocupação até em relação à autoestima do estudante que se percebe sem condições de continuar os estudantes. Para o mesmo, o ProUni, “como é um programa voltado para pessoas de baixa renda, existem materiais que tonam-se caros e comprometem a permanência, rendimento e autoestima para prosseguir em determinados momentos" (B21, informação verbal). 
De fato, a bolsa permanência do ProUni ainda é muito pequena, em termos de abrangência e valor. Esse, talvez seja um dos pontos de entrave do programa. Apesar da pequena amostra para esse trabalho, viu-se que a grande maioria dos bolsistas não usufrui do benefício. Portanto, faz-se necessário pensar em alternativas que melhorem esse quadro, pois não deve ser nada fácil a um bolsista que cursa odontologia, medicina, engenharia e tantos outros cursos cujo material é extremamente caro, permanecer na instituição até o final.

\subsubsection{Gestores governamentais e dirigentes do setor privado}

Para ter uma dimensão mais ampla sobre o Programa Universidade para Todos, decidiu-se por incluir sujeitos que representassem diferentes segmentos da política. Por isso, entrevistou-se gestores do Ministério da Educação, da instituição privada de educação superior, assim como o representante de uma associação que defende os interesses das IES privadas. Além desses, pensou-se ainda, na inclusão dos beneficiários do ProUni na pesquisa, para completar o cenário de percepções acerca da política.

Assim como prevê a categoria da contradição, impressa no olhar metodológico deste trabalho, abordar as opiniões do setor público, privado e dos beneficiários do programa, possibilitou criar um quadro analítico que expôs fragilidades, mas também avanços promovidos por suas ações. As contradições presentes na política puderam ser percebidas a partir da percepção que cada um desses sujeitos tem da totalidade do fenômeno, o que inclui a questão da expansão e da democratização do acesso à educação superior no país.

Depreende-se então que quanto mais diversificada for a participação dos sujeitos, mais expostos estarão os alcances e limites da política pesquisada. Na sequência, apresenta-se quadro com a descrição dos sujeitos entrevistados. 
Quadro 8 - Sujeitos entrevistados - 2016

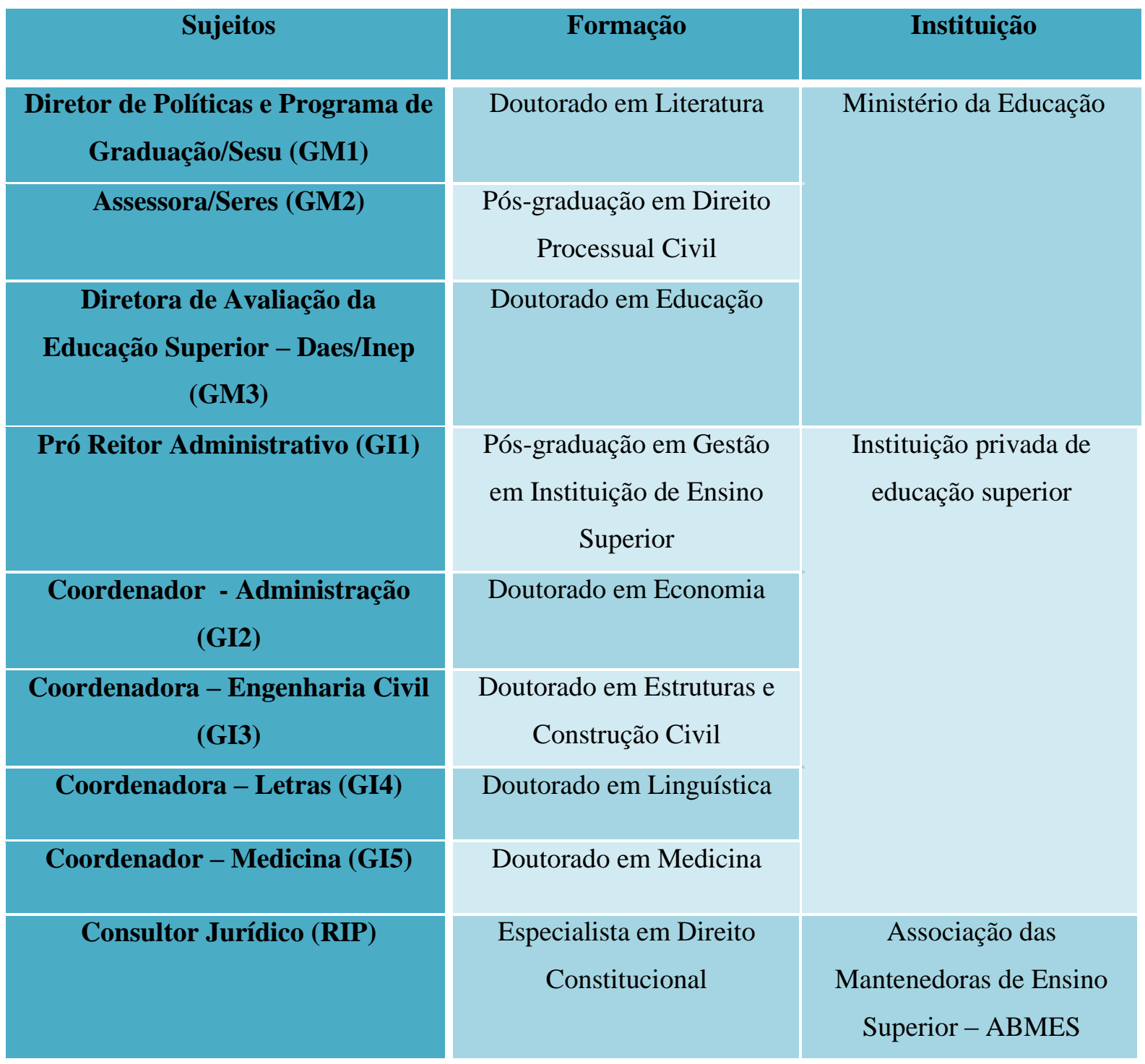

Elaborado pela autora. GM1,GM2,GM3(Gestor MEC 1, 2 e 3); GI1,2,3,4 e 5 (Gestor Institucional 1, 2. 3,4, e 5) e RIP (Representante Instituições Privadas) ${ }^{74}$

\subsection{O olhar dos bolsistas sobre o ProUni: uma análise à luz dos beneficiados}

Esta pesquisa teve como objetivo analisar o impacto de uma política pública que, como toda ação governamental, é impregnada de contradições. Para que fosse possível ter uma visão mais ampla do programa, considerou-se relevante fazer uma "triangulação" de instrumentos de coleta de dados (questionário, entrevista e documentos), bem como de sujeitos (discentes, gestores e representante da associação de mantenedoras das IES). Nesse sentido, a avaliação dos bolsistas em relação ao ProUni foi importante para confrontá-la com

\footnotetext{
${ }^{74}$ As siglas serão usadas para fazer referência aos entrevistados, quando citadas suas falas.
} 
a narrativa dos gestores, assim como com a abordagem realizada por vários autores que escreveram sobre o tema e que foram abordados ao longo deste trabalho.

Nessa perspectiva, foi enviado um questionário, via google forms, com perguntas de múltipla escolha, para a construção do perfil desses alunos e que já foram analisados no início deste capítulo. Nesse mesmo instrumento, foram realizadas questões intervalares, com valores de 1 a 6, para que o bolsista marcasse a que mais se aproximasse de sua opinião acerca do que estava sendo perguntado. Por fim, foi feita uma questão aberta com a solicitação de que se fizessem críticas ou sugestões relacionadas ao programa.

Para a interpretação das respostas dadas por meio dos intervalos, foi utilizado o software estatístico Statistical Package for the Social Sciences - SPSS, o qual auxilia na descrição dos dados a partir do cálculo da média e do seu respectivo desvio padrão $(s)$ e o coeficiente de variação. Segundo Levin; Fox e Forde (2012), o “uso da média é exclusivamente restrito a dados intervalares e [...] é muito influenciada por escores extremos em qualquer uma das direções” (p. 79 e 87). Além disso, essa medida tem menos variabilidade nas "amostras tiradas de qualquer população dada" (p. 91). Em outras palavras, o desvio padrão é o quanto as respostas variam ao redor da média; é uma medida de dispersão. Para exemplificar, os autores disseram que "quanto maior a variabilidade em torno da média de uma distribuição, maior o desvio padrão. Desse modo, $s=4,5$ indica maior variabilidade do que $s=2,5$ " (p. 106), em um intervalo de 1 a 6 .

No questionário havia algumas alternativas, relativas ao ProUni, que deveriam ser marcadas a partir da concordância ou não do bolsista, na escala proposta, no intervalo de 1 a 6. A seguir, apresenta-se tabela com cálculo da média, do desvio padrão e do coeficiente de variação que indicou o quanto o bolsista concordou ou não com a afirmação e, também, qual foi o nível de dispersão dessas respostas, ou seja, o quanto elas variaram em relação à média. 
Tabela 12 - Descrição estatística com o cálculo da média e do desvio padrão - 2016

(continua)

\begin{tabular}{|c|c|c|c|c|c|c|}
\hline \multicolumn{6}{|c|}{ Estatística descritiva } & \multirow[b]{2}{*}{ 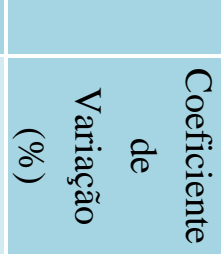 } \\
\hline Questões & Z & 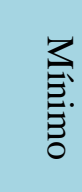 & 竎 & $\stackrel{3}{\stackrel{2}{2}}$ & 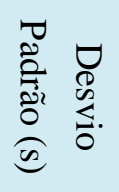 & \\
\hline $\begin{array}{l}\text { O ProUni contribui para a expansão } \\
\text { do acesso à educação superior. }\end{array}$ & 65 & 3 & 5 & 4,69 &, 584 & 12,45 \\
\hline $\begin{array}{l}\text { O ProUni contribui para que a } \\
\text { expansão do acesso à educação } \\
\text { superior alcance os segmentos da } \\
\text { sociedade, mais desprovidos } \\
\text { economicamente. }\end{array}$ & 66 & 2 & 5 & 4,42 & ,805 & 18,21 \\
\hline $\begin{array}{l}\text { O ProUni contribui para que alunos } \\
\text { de baixa renda possam frequentar } \\
\text { cursos de alto custo, como } \\
\text { medicina e engenharia civil. }\end{array}$ & 66 & 1 & 5 & 4,23 & 1,005 & 23.75 \\
\hline $\begin{array}{l}\text { O ProUni contribui para o acesso e } \\
\text { permanência de alunos cotistas } \\
\text { (pretos, pardos, indígenas e } \\
\text { portares de deficiência) tanto em } \\
\text { cursos de alta concorrência, como } \\
\text { medicina e engenharia civil, quanto } \\
\text { em cursos menos concorridos, } \\
\text { como administração e letras. }\end{array}$ & 64 & 1 & 5 & 3,69 & 1,332 & 36.09 \\
\hline $\begin{array}{l}\text { A expansão e democratização do } \\
\text { acesso à educação superior não } \\
\text { seria possível sem o setor privado e } \\
\text { políticas públicas com a do ProUni. }\end{array}$ & 66 & 1 & 5 & 3,56 & 1,242 & 34,88 \\
\hline $\begin{array}{l}\text { O ProUni é uma política pública } \\
\text { que mais beneficia as instituições } \\
\text { de educação superior privadas, do } \\
\text { que o estudante de baixa renda. }\end{array}$ & 64 & 1 & 5 & 2,75 & 1,234 & 44,87 \\
\hline $\begin{array}{l}\text { O ProUni auxilia os estudantes a ter } \\
\text { uma profissão. }\end{array}$ & 66 & 1 & 5 & 4,12 & 1,222 & 29.66 \\
\hline $\begin{array}{l}\text { O governo deveria ter avaliações } \\
\text { mais sistemáticas do Programa } \\
\text { Universidade para Todos. }\end{array}$ & 64 & 1 & 5 & 3,83 & 1,149 & 30,00 \\
\hline
\end{tabular}


Tabela 12 - Descrição estatística com o cálculo da média e do desvio padrão - 2016

(conclusão)

\begin{tabular}{|c|c|c|c|c|c|c|}
\hline \multicolumn{6}{|c|}{ Estatística descritiva } & \multirow[b]{2}{*}{ 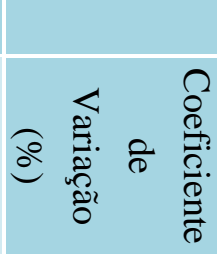 } \\
\hline Questões & z & : & 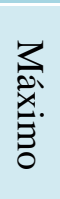 & $\underset{2}{\stackrel{3}{2}}$ & 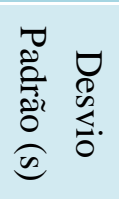 & \\
\hline $\begin{array}{l}\text { A bolsa permanência do ProUni } \\
\text { atende às necessidades financeiras } \\
\text { dos estudantes. }\end{array}$ & 65 & 1 & 5 & 2,65 & 1,408 & 53,13 \\
\hline $\begin{array}{l}\text { O Programa Universidade para } \\
\text { Todos melhorou minha vida, ao } \\
\text { criar condições para o ingresso em } \\
\text { uma instituição de educação } \\
\text { superior. }\end{array}$ & 66 & 1 & 5 & 4,44 & ,930 & 20,94 \\
\hline $\begin{array}{l}\text { Sem o ProUni, dificilmente, eu } \\
\text { teria condições de ingressar em um } \\
\text { curso de nível superior. }\end{array}$ & 66 & 1 & 5 & 3,15 & 1,552 & 49,26 \\
\hline
\end{tabular}

Fonte: Cruzamento de dados do questionário aplicado aos bolsistas, com a utilização do SPSS.

$\mathrm{N}=$ quantidade de bolsistas que responderam à questão. Elaborado pela autora

A partir da explicação feita por Levin, Fox e Forde (2012) acerca do cálculo da média, do desvio padrão e do coeficiente de variação, pode-se inferir que as respostas com menor desvio padrão, portanto, menor variabilidade, são aquelas em que o valor da média apresenta-se mais consistente. Traduzindo, segue quadro na ordem de maior concordância para a menor, em relação às afirmações apresentadas pelo questionário.

Quadro 9 - Relação das respostas dos bolsistas, em ordem decrescente, segundo a variabilidade média - 2016

(continua)

1. O ProUni contribui para a expansão do acesso à educação superior.

2. O ProUni contribui para que a expansão do acesso à educação superior alcance os segmentos da sociedade, mais desprovidos economicamente.

3. O Programa Universidade para Todos melhorou minha vida, ao criar condições para o ingresso em uma instituição de educação superior.

4. O ProUni contribui para que alunos de baixa renda possam frequentar cursos de alto custo, como medicina e engenharia civil.

5. O ProUni auxilia os estudantes a ter uma profissão.

6. O governo deveria ter avaliações mais sistemáticas do Programa Universidade para Todos

7. A expansão e democratização do acesso à educação superior não seria possível sem o setor privado e políticas públicas como a do ProUni.

8. O ProUni contribui para o acesso e permanência de alunos cotistas (pretos, pardos, indígenas e portares de deficiência) tanto em cursos de alta concorrência, como medicina e engenharia civil, quanto em cursos menos concorridos, como administração e letras. 
Quadro 9 - Relação das respostas dos bolsistas, em ordem decrescente, segundo a variabilidade média - 2016

(conclusão)

9. O ProUni é uma política pública que mais beneficia as instituições de educação superior privadas, do que o estudante de baixa renda.

10. Sem o ProUni, dificilmente, eu teria condições de ingressar em um curso de nível superior.

11. A bolsa permanência do ProUni atende às necessidades financeiras dos estudantes.

Fonte: Elaborado pela autora

Para exemplificar, pode-se dizer que os bolsistas concordam bastante que o ProUni contribui para a expansão do acesso à educação superior. Assim como acreditam, fortemente, que o programa alcança os mais desprovidos economicamente. Na sequência, observa-se que a maioria confia que, ao criar condições para cursar uma graduação, a política melhorou sua vida. Concentrando-se que nas últimas três afirmações, pode-se dizer que houve bastante variabilidade nas respostas referente à questão de o programa beneficiar mais as instituições privadas que o próprio bolsista, o que sugere não haver uma posição muito definida em relação a essa questão. Sobre o fato de que sem o ProUni, dificilmente o aluno teria condições de ingressar em um curso de nível superior, também não há unanimidade, nem mesmo muita consistência nas respostas. O pensamento dos bolsistas sobre o assunto é bastante disperso. Por último, a afirmação relativa à função da bolsa permanência e sua capacidade em atender às necessidades financeiras dos estudantes é a que mais apresentou variabilidade, indicando diferentes entendimentos acerca do assunto.

A partir dessa análise, pode-se inferi que, ao analisar o coeficiente de variação das respostas, os bolsistas, em geral, consideram que o ProUni contribui para que estudantes de baixa renda possam frequentar cursos de alto custo, como medicina e engenharia, além de concordarem, em sua maioria, que o programa auxilia os mesmos a terem uma profissão. Paradoxalmente, apesar dos bolsistas considerarem que o ProUni contribuiu para melhorar sua vida, por possibilitar ingressar num curso de graduação, eles não consideram, por unanimidade, que sem essa política, seu acesso à educação superior estaria inviabilizada. Outra constatação diz respeito ao ingresso de bolsistas em cursos de alta concorrência, como medicina e engenharia. Apesar de eles concordarem que o programa contribuiu para isso, houve muita variabilidade nas respostas referente ao ingresso de cotistas (negros, indígenas e pessoas com deficiência), no que tange a esses mesmos cursos. Depreende-se daí que a democratização do acesso à educação superior, entendida como inclusão de minorias em espaços tradicionalmente ocupados pela elite, não é uma evidência consistente. 
No que diz respeito às outras duas questões, que fizeram referência à relação entre o programa e o setor privado, evidenciou-se uma variabilidade relativa nas respostas, talvez, pelos bolsistas terem pouca clareza acerca do tema. Afinal, conhecer a lógica da política educacional do país não é tarefa do estudante. Este tende apenas a observar o que o Estado está fazendo para beneficiá-lo por meio das políticas públicas. Para opinar acerca do caráter e da essência dos programas governamentais, faz-se necessário compreender a opção do modelo de Estado feita pelos governos. Isso não é uma tarefa comumente assumida pela sociedade, de maneira geral.

\subsection{O que pensam os gestores? (MEC, IES e ABMES)}

Esta parte do trabalho tem como propósito descrever e analisar, à luz das categorias selecionadas para tal objetvo, conforme já destacadas ao longo desta dissertação, as posições dos sujeitos entrevistados. Considerando que os interesses, visões e objetivos das pessoas que responderam às perguntas, são bem diferentes, torna-se ainda mais instigante a compreensão de suas posições. Há de considerar que as perspectivas do gestor público não são as mesmas do dirigente do setor privado, por conseguinte, são essas contradições que precisam ser desveladas, a fim de que a discussão seja enriquecida e os objetivos propostos na pesquisa alcançados.

\subsubsection{A expansão da educação superior e o ProUni como condutor do processo de democratização do acesso, com equidade}

Esta pesquisa objetivou analisar a capacidade que o ProUni tem de promover a democratização do acesso à educação superior no país. Como já foi aqui exposto, esse fenômeno não pode ser entendido como a simples expansão da oferta de vagas. A perspectiva pretendida por este trabalho foi a da ampliação de direitos.

Como exposto ao longo desta dissertação, a sociedade brasileira é marcada por fortes assimetrias, que estão reveladas nos diferentes dados estatísticos aqui relatados. A indiscutível hegemonia do setor privado no cenário da educação superior, a preponderância dos brancos nas IES, assim como a presença dos mais ricos, tanto nas instituições públicas quanto nas privadas de educação superior evidenciam os desafios que as políticas governamentais de educação têm para a superação dessas características, a fim de alcançar uma sociedade mais justa e cidadã. 
Outros dados dão conta de um diagnóstico desalentador em relação ao cenário educacional brasileiro. No que diz respeito à educação superior, mais especificamente ao ProUni, algumas categorias foram selecionadas para abordar o assunto junto aos entrevistados. Em que pese o fato do ProUni ser o objeto central dessa pesquisa, as perguntas foram elaboradas a partir das categorias: expansão, democratização, equidade e qualidade.

Ao responderem à questão relacionada ao processo de expansão da educação superior nos governos FHC e Lula e como avaliavam o financiamento desse nível educacional, pode-se dizer que todos concordaram que houve forte expansão no âmbito desses governos. Os gestores do setor privado tendem a considerar que o governo de FHC preparou o terreno para que Lula pudesse ampliar as políticas de acesso a esse nível educacional, com o ProUni e o Fies, por exemplo. Quando compararam os governos anteriores ao governo da presidente Dilma, sobram críticas em relação aos cortes no financiamento das políticas para esse setor.

Eu acho que o Fernando Henrique pavimentou, fez uma pavimentação. Permitiu uma plataforma, com a evolução seguinte, do governo Lula. Então, desde aquela época começou (sic) as novas diretrizes de base em 96, que foi muito importante naquela época [...] houve uma inserção e, infelizmente, a qualidade que se esperava não acompanhou. Então, a gente tem uma série de problemas. Muitas universidades e faculdades resolveram acolher e entraram com convênio com o governo federal, mas sem ter muita base também [...] (GI2 - informação verbal).

[...] eu acho que houve uma iniciativa de expansão no governo do Fernando Henrique Cardoso [...] eu vejo uma continuidade e uma crescente entre Fernando Henrique e Lula. O que eu vejo de ruim, de não continuidade nessa expansão realmente agora com a situação econômica. Então, se comparar Fernando Henrique e Lula eu acho que é a continuidade. A Dilma, ela realmente prejudicou esse processo por não prever um orçamento à continuidade [...] (GI1 - informação verbal).

[...] todo o investimento foi feito desde 1990, seja no governo Fernando Henrique, seja no governo Lula [...] no governo atual está indo ralo abaixo, esse é o sentimento que eu tenho hoje. Eu acho que fizeram muitas coisas boas, acho que a expansão do FIES foi uma coisa muito boa para a educação superior e o ProUni foi muito bom, mas, infelizmente, nesse momento é um momento de crise muito grande e as instituições de ensino privado, inclusive, têm sentido bastante, porque ela vinha acomodada [...] por esses tipos de apoio do governo federal e hoje, realmente, está bem difícil. Então, teve um "bomm" disso aí, que foi muito bom, muito positivo, mas que, em minha opinião, precisavam de melhorias [...] (GI3 - informação verbal).

Olha aqui no Distrito Federal, que [é] o contexto que eu tenho experiência como docente, como coordenador de curso de graduação, eu percebi que a partir de Fernando Henrique que os alunos, os jovens estão tendo mais acesso, mas isso trouxe algumas consequências, por exemplo, nós estamos em uma instituição que é privada e foram abertas várias faculdades particulares, várias instituições particulares nesse período, o que fez com que caísse a qualidade do ensino superior e, assim, o acesso aumentou mais, teve 
um impacto na qualidade do ensino [...] a partir desse momento que o Fernando Henrique abriu esse espaço para o ensino superior, o governo começou a pensar e nós ficamos até felizes com os programas que foram criados, o ProUni e o Fies. Foram criados os programas para ajudar a financiar esse ensino superior para a população que não tinha acesso. Mas até que ponto que a gente consegue agora manter isso? (GI4 - informação verbal).

Observa-se nas falas desses gestores da IES o reconhecimento da importância das políticas públicas de financiamento da educação superior, mas, ao mesmo tempo, a preocupação com a descontinuidade dos programas. Além disso, alguns sugerem que a expansão do acesso foi acompanhada de queda na qualidade dos cursos, o que é refutado por uma gestora do MEC. Segundo ela, em

[...] termos de políticas e programas a gente também começa a acompanhar, por meio de questionários, o próprio Enade [...] eles foram sendo alterados pra incluir pesquisas que pudessem relacionar o desempenho do estudante com aqueles que ingressaram por meio de políticas afirmativas e de políticas de acesso à educação superior, relacionadas ao financiamento. Então, sem dúvida a gente tem o acompanhamento que aumentou muito o financiamento e [que], por isso, aumenta a inclusão de estudantes à educação superior [...]. Uma das coisas que se destacam também na gestão do governo Lula é atrelar a avaliação às políticas de financiamento. Então, um curso, para ter acesso ao ProUni, pra ter acesso ao Fies, ele [tem] que ser um curso bem avaliado, porque o que se pretende é a garantia de que este estudante que tá tendo acesso a financiamento ele acesse curso de boa qualidade. Então, hoje, você considerar que pra que esses cursos possam acessar o Fies ou o ProUni têm que ter um bom resultado na avaliação; é a garantia dessa qualidade [...] O ProUni, por sua vez, também fica impactado pela avaliação porque sua permanência no sistema de ensino depende do resultado da avaliação.(GM3 - informação verbal).

No âmbito governamental, os gestores reconhecem o papel da expansão implementada por FHC, mas consideram que as políticas educacionais do seu sucessor foram mais diversificadas. Talvez por ocuparem cargos de direção no Ministério, os gestores tendiam a se limitar em descrever as ações da gestão Lula, talvez, por serem sujeitos que contribuíram, em algum momento, com a política de educação superior desse governante. Ainda sobre a expansão da oferta de vagas do referido nível educacional, um representante dos gestores diz que

[...] a gente tem, obviamente, uma forte expansão, muito significativa. A gente tem hoje 7 milhões de alunos, mais ou menos, no ensino superior, que é ainda um número aquém dos objetivos. O PNE tem uma perspectiva de dobrar esse número [...] há um crescimento, obviamente uma expansão muito forte, muito consistente que eu acredito importantíssima pra 
transformação da realidade econômica e social do país. A expansão contou com a expansão do setor público, mas mais fortemente do setor privado [...] ainda no governo Fernando Henrique Cardoso a mudança da LDB que permitiu que entidades com fins lucrativos ofertassem ensino médio e superior, isso fez uma diferença de fato. Atraiu um grupo de empresas e de empresários interessados em explorar esse ramo e isso foi importante. Tem sido bastante importante pra expansão [...] (GM2 - informação verbal)

Essa fala vai ao encontro do que já foi abordado nesta dissertação em relação à ampliação e diversificação do espaço privado na oferta de educação superior no país. Confirma ainda o cenário favorável a essas questões, no governo de FHC, com continuidade a essa tendência, no governo Lula.

No entanto, ao abordar a expansão no governo Lula, os gestores do MEC ressaltam o investimento feito também no setor público e destacam o financiamento de políticas também para esse segmento. Como já abordado, apesar da lógica privatista presente em seu governo, o que o diferencia de seu antecessor é o olhar direcionado à expansão, também pela via pública. Conforme um dos gestores entrevistados,

[...] Lula, eu acho que é outro momento. O governo Lula já iniciou com uma proposta de tornar as universidades federais referências do sistema da educação superior. [...] o principal, me parece que do governo Lula foi de levar, paralelamente, a expansão do setor privado e a expansão das universidades públicas, lado a lado. E compondo isso, tanto no setor privado quanto no setor público com o elemento da inclusão. Então, a expansão do setor privado começa a incluir, via ProUni, já em 2004, 2005, na verdade e continua se expandindo normalmente, só que via ProUni, você começa a colocar um grande número de pessoas carentes na educação superior, o que é revolucionário. E depois, em 2010, aí com o novo Fies também essa nova expansão. E no setor público, especialmente, via expansão, via interiorização e via Sisu [...] (GM1 - informação verbal, grifos nossos).

Sem dúvida, acho que muito mais até, o esforço é na via do setor público. A expansão por meio do Reuni, das instituições federais foi muito maior no âmbito da rede pública. É que sempre foi maior a oferta na educação privada, então ele representa a maioria em termos de instituições, mas em termos de matrículas a gente tem uma maioria, um grande número de estudantes na rede pública. Então, as duas vias, elas têm expansão. Há, sem dúvida, nas últimas gestões, um investimento muito [maior ou menos] no setor público, na rede federal tecnológica e também naquelas instituições. A ampliação do número de universidades públicas foi, sem dúvida, mais de $50 \%$, o que não houve na gestão anterior. (GM3 - informação verbal).

Olhando para o censo da educação superior de 2003 e 2014, os dados apresentados indicam um aumento de instituições públicas (federais, estaduais e municipais) de 30,53\%. Entre as privadas (particulares, confessionais, comunitárias e filantrópicas), a expansão se deu na casa dos 20,19\%. Em 2003 eram 207 IFES e no ano de 2014 o número era de 298. Isso 
mostra o investimento do governo Lula no segmento da educação pública, conforme relatou a gestora, mesmo não sendo na proporção, por ela apresentada. Ainda assim, superou o do segmento privado, que em 2003 tinha 1.652 estabelecimentos e em 2014 chegou a 2.070 (INEP, 2005; 2016).

Em relação às matrículas, o percentual de ampliação foi um pouco menor do que o apresentado pelas instituições particulares. Entre 2003 e 2014, o setor público aumentou o número de matrículas em $37,61 \%$ e no âmbito das IES privadas o crescimento foi de $41,0 \%$. Pode-se dizer, portanto, que no governo Lula, tanto o setor público quanto o privado foi privilegiado. Por isso, seu governo foi acusado de seguir a mesma lógica neoliberal de seu antecessor, ao financiar vagas da educação superior, tão fortemente, pela via privada. Como foi, reiteradas vezes, destacado ao longo dessa dissertação, os programas educacionais de parceria público-privado, como o ProUni, foram duramente criticados pelos defensores da universidade pública e gratuita.

Em relação a esse assunto, há certa unanimidade entre os entrevistados de que, sem o setor privado, não haveria condições de se alcançar a meta estabelecida pelo Plano Nacional de Educação que estabelece o alcance de $33 \%$ de taxa líquida de jovens acessando a educação superior até 2024. Há de convir que, mesmo com essa parceria, a meta estabelecida pelo PNE anterior, de 30\%, ficou longe dos $17 \%$ atingidos, aproximadamente. Segundo gestores entrevistados,

[...] se você comparar as metas do plano nacional de educação para o ensino superior, sem iniciativa privada o governo não vai atingir essa meta e agora simplesmente ele fechou a torneira, mas por uma falta de planejamento. Acho que uma falta de planejamento fez com que neste cenário, vai reduzir muito o avanço, o recuo desses $16 \%$ que poderiam virar $24 \%$ ou $25 \%$, então nós vamos retardar esse crescimento[...] Sem o setor privado o governo não atinge meta. (GI1 - informação verbal)

[...] o próprio governo Lula, no princípio, até ele questionou muito o problema da expansão das universidades privadas, começou com o Fernando Henrique, mas depois, ele mesmo, ele aprovou muito mais permissão pra curso de universidade privada do que o FH. Mas seria um caminho natural [...] não tem como bancar toda essa expansão. Ele tinha que se valer realmente da iniciativa privada, que foi acertado. Eu acho que fizeram, não critico. [...] o governo não tem recurso inesgotável. Eu acho que foi uma grande sacada do governo Lula, por ter continuado, por permitir abertura de universidades públicas, privadas (GI2 - informação verbal)

Por fim, um gestor do MEC, ao avaliar a atuação do governo Lula em relação às políticas educacionais de nível superior, considera que na gestão desse a iniciativa privada foi fortemente privilegiada, principalmente, devido às políticas do ProUni e do Fies. 
[...] é só olhar os números. Quantas matrículas têm o setor privado? Cinco milhões e trezentas mil. Quantos contratos têm no Fies? Dois milhões e trezentos mil. Matrículas ativas no ProUni? Seiscentos e cinquenta mil. Vamos contar só as ativas para não ser injusto, pegar só as ativas. Dois milhões e novecentas e cinquenta mil. Das cinco milhões e trezentas mil matrículas são totalmente financiadas por recursos públicos [...] é importante isso, porque aqui tu tens a dimensão da participação do governo Lula-Dilma no setor privado, $\mathbf{5 6 \%}$ de todas as matrículas do setor privado são públicas, são financiadas por recursos públicos. Isso aqui eu chamo de matrículas público-privadas. É uma parceria públicoprivada. Se tu somar mais $25 \%$ que nós já temos de matrículas públicas, aí você chega a $81 \%$, praticamente das matrículas públicas. Os outros são públicas e gratuitas e essas são públicas no setor privado, também gratuitas para o aluno, só que por outra modalidade. O setor acha que dois milhões e duzentos mil contratos é pouco, eu chamo de ter sede demais para ir ao pote. Não tô nem falando das irregularidades que frequentemente são cometidas, que são de cobrar para o governo três vezes o que cobra do pagante. Nós temos vários casos, não é tendência generalizada, mas você tem instituições que fazem isso [...] (GM1- informação verbal, grifos nossos).

A fim de destacar a importância do setor privado para a expansão do acesso à educação superior no país, o representante da associação que defende os interesses desse segmento fez um breve resgate histórico, explicando que essas instituições sempre estiveram presentes na oferta desse nível educação, desde os primórdios. Sua análise ratifica a abordagem aqui realizada de que o modelo educacional para a oferta de graduação no país foi, na sua origem, privado e elitista. Esse padrão se perpetuou e o Estado não conseguiu inverter essa lógica, fazendo com que as IES privadas se mantivessem predominantes. Quando perguntado sobre o papel da Constituição de 1988 e da Lei de Diretrizes e Bases de 1996 para estimular a privatização da educação superior no país ele disse considerar

[...] muito importante romper essa discussão ideológica. Vamos tentar ter uma discussão um pouco mais técnica. Vamos fazer uma análise constitucional. Você tem a questão da livre iniciativa, onde, de fato, primeiro quem trouxe a educação para o país foi o setor privado, através dos jesuítas. $\mathrm{O}$ estado só acordou muito depois, quando se instalou a faculdade de direito em Recife e em São Paulo já no século XIX [...] de onde eles já tinham vindo muito antes. Então, na verdade, a gênese da nossa educação é do segmento privado, é confessional e sem fins lucrativos, mas é privado. $\mathrm{O}$ estado brasileiro demorou muito pra perceber o alcance ou a importância da educação [...] (RIP - informação verbal).

Sobre a origem do setor privado na oferta de educação no país, vale retomar a interpretação de Cury (2009) ao considerar a Reforma Rivadávia Corrêa, realizada entre 1911 e 1915, determinante para esse movimento, o qual denominou de "desoficialização" do ensino no Brasil. Para o autor, foi a partir da Constituição Federal de 1891 que o governo ratificou 
sua tendência em abrir espaços a outros setores da sociedade, para a oferta de ensino. Ainda, segundo ele, a Lei Orgânica do Ensino Superior e do Fundamental da República, de 1911, foi o primeiro documento que assumiu, claramente, "a desoficialização" do ensino público.

O representante das IES privadas critica ainda, a visão dos últimos gestores do MEC, sobretudo as de Fernando Haddad e Tarso Genro, para quem a participação privada na educação superior era uma coisa neoliberal, uma invenção de FHC e de Paulo Renato de Souza. Segundo ele, isso é mentira.

[...] Surgiu em 34, na Constituição de 34. E é uma época de um estado totalitário. Ele [Getúlio Vargas] queria vagas, então não quer dizer que ele queria um favorzinho que era bonzinho, não. Eu acho que se percebeu que o estado sozinho não teria condições de garantir educação pra todo mundo, muito menos com um padrão satisfatório de qualidade. Daí, permitir que a livre iniciativa explorasse a educação desde que garantida a qualidade, $o$ processo de autorização, essa coisa toda que tá na Constituição atual. Então, assim, na verdade, não foi o governo de Fenando Henrique que permitiu a atuação privada na educação. O que talvez tenha acontecido na época do $\mathrm{FH}$ foi de se permitir que as empresas com fins lucrativos se tornassem mantenedoras, porque antes não podia ter mantenedor privado, desde que fossem sem fins lucrativos. As associações, as fundações ou as confessionais. Então, houve, na verdade, o que a gente pode dizer é que talvez se tenha perdido o pudor de admitir que a educação também é um negócio e eu, particularmente, não vejo nenhum problema nisso. Eu vejo problema na educação como negócio se o produto é ruim (RIP informação verbal, grifos nossos).

Pois bem, sua avaliação, apesar de legítima, vai de encontro à ideia de que educação não pode ser vista como um serviço ou um produto. Deve, sim, ser percebida como um meio de transformação da realidade, em todas as suas dimensões. A educação deve ser percebida como alternativa para emancipação social, econômica, cultural e política. É compreensível a narrativa do referido sujeito, RIP, acerca da importância do setor privado para a oferta de educação superior no país, afinal, é indiscutível a hegemonia desse. No entanto, questiona-se o caráter formativo e emancipador da educação, quando essa, é tratada como negócio. Ao abrir mão do papel de provedor da educação, o Estado acaba tendo de assumir a função de fiscalizador e regulador de forma mais contundente a fim de tentar manter a qualidade da qual cita o representante das IES privadas.

Por outro lado, descortina-se a contradição presente na crítica de Fernando Haddad e Tarso Genro, aqui referenciada, quando se remete aos números citados pelo GM1 acerca das vagas no setor privado, financiada pelo Estado, além das essencialmente privadas. Esse relato diz bastante do quanto esse setor foi privilegiado pelos governos Lula e Dilma, por meio dos 
programas de expansão e democratização do acesso à educação superior, como o ProUni e o Fies.

Sobre o assunto, foco principal da pesquisa, os entrevistados acreditam na tendência de que o ProUni promove a democratização do acesso à educação superior. No entanto, quando perguntados sobre a questão da equidade, na medida em que a política reserva cotas para negros, indígenas e pessoas com deficiência, a discussão toma outra dimensão. É nesse momento, portanto, que emerge da fala de boa parte dos entrevistados, as categorias: educação básica de qualidade e cotas, por entenderem que a verdadeira democratização acontece quando todos têm acesso a esse nível de educação, com qualidade. Grande parte dos entrevistados entende que as políticas públicas devem prescindir das cotas, por considerarem uma regra injusta, ou seja, justamente o inverso do que propõe a iniciativa.

Sendo assim, essas categorias foram analisadas, a partir do entendimento dos sujeitos e da relação deles com o objeto proposto por essa pesquisa. Conforme compreensão de Franco (2008), "esse processo inicia-se pela descrição do significado e do sentido atribuído por parte dos respondentes, salientando-se todas as nuanças observadas" (p. 61).

A percepção de que um assunto foi compreendido da mesma maneira por pessoas diferentes é que evidencia o surgimento de uma categoria de conteúdo. Ao serem questionados sobre um tema, os sujeitos destacam uma dimensão que não tinha sido pensada e passa a ser recorrente, nas diferentes questões e falas. Ainda segundo Franco (2008), as

[...] categorias vão sendo criadas à medida que surgem nas respostas, para depois serem interpretadas à luz das teorias explicativas. Em outras palavras, o conteúdo, que emerge do discurso, é comparado com algum tipo de teoria. Infere-se, pois, das diferentes "falas", diferentes concepções de mundo, de sociedade, de escola, de indivíduo, etc. (p. 62).

Para tentar encontrar resposta à questão que norteia esse trabalho, assim como para atender ao objetivo geral, por ele proposto, foram realizadas algumas perguntas relacionadas à capacidade do ProUni em promover a democratização do acesso à educação superior e, mais do que isso, se esse fenômeno é alcançado com equidade.

Em geral, foi preciso explicar o que se queria dizer com "democratização com equidade". Como, apesar de existir diferentes entendimentos acerca das duas categorias tanto "democratização", quanto "equidade" -, fez-se necessário dizer qual sentido a pesquisa pretendia abordar.

Como já explicitado nesta pesquisa, por meio de trabalhos como os de Azevedo (2013), Dias Sobrinho (2010; 2013) e Nogueira (2008), os conceitos de democratização e 
equidade são aqui entendidos como ampliação de direitos, inclusão de minorias e conquista da cidadania, lastreada pela justiça social. Ressalta-se a importância em observar as diferentes compreensões acerca do tema, considerando que os mesmos conceitos são vistos de maneira diversa, conforme abordaram os referidos autores.

Silva (2012), em sua obra Estado, Educação e Equidade no Brasil, discorre sobre como a equidade é vista por teóricos de diferentes correntes, como a do iluminismo liberal, a da ideologia gerencialista e a do comunitarismo. Segundo o autor, "a equidade tem, portanto, em diferentes domínios teóricos, um estatuto normativo. Contudo, ela pode ser compreendida de diversas maneiras mais ou menos conservadoras, sobretudo frente à promoção dos direitos sociais e econômicos" (p. 82).

Reitera-se, portanto, a opção desta pesquisa em abordar a democratização com equidade, como valor social para conquista da cidadania e, além disso, como dimensão obrigatória das políticas públicas que buscam reduzir as assimetrias socioeconômicas presentes na sociedade brasileira. Afinal, não há como concordar com a visão liberal de que o Estado é uma associação privada. Segundo Silva (2012), essa concepção “é uma das maneiras mais reducionistas de se pensar o poder público, minimizando suas formas de intervenção na sociedade, quando não se trata de agir como um instrumento a serviço da acumulação privada. Para tal Estado não existe questões sociais" (p. 84).

Portanto, por acreditar que o Estado deve atuar junto às disfunções presentes na sociedade, sobretudo ao que diz respeito às suas mazelas, entenda-se que as políticas implementadas pelo governo precisam dar tratamento desigual aos social e economicamente desiguais. Para que seja possível perceber o quanto o ProUni agindo nessa direção, vale destacar a posição dos bolsistas pesquisados, frente ao programa. Das onze questões feitas aos beneficiários da instituição, as cinco que tiveram mais coesão nas respostas, ou seja, que os alunos mais concordaram entre si, foram relacionadas à capacidade do ProUni de promover a expansão da educação superior. Segundo eles, a referida expansão se dá alcançando os segmentos mais desprovidos economicamente, criando condições para que esse grupo ingresse numa IES. Além disso, concordam que o programa contribui para que alunos carentes possam frequentar cursos de alto custo e demanda, como Medicina e Engenharia. Por fim, os estudantes, em sua maioria, acreditam que essa política os auxilia a ter uma profissão.

Considerando o entendimento de equidade, como justiça social, vale destacar o relato de uma entrevistada em que discorre sobre o tema da democratização do acesso à educação superior, sob essa perspectiva. 
O acesso à educação superior é uma proposta de promoção da equidade, da igualdade de direitos. No momento em que você tem acesso à educação superior, e ela é entendida como bem público, ela é entendida como direito das pessoas, você tá promovendo a equidade. $O$ estudante que tem acesso à ES, em tese, ele tem melhores condições de empregabilidade depois, e de melhoria de toda a sua família. Não é incomum hoje, a gente vê que uma pessoa que acessa a ES ela consegue uma inclusão social não só dela, mas ela promove o bem estar de toda a família. Então, a possibilidade dessas políticas e a democratização do acesso, ela vem em prol das políticas de equidade (GM3 - informação verbal, grifos nossos).

\subsubsection{O ProUni e as cotas étnico-raciais: cadê a escola básica de qualidade?}

Quando os entrevistados foram perguntados sobre sua análise acerca da relação entre o ProUni, a democratização do acesso e a reserva de cotas para negros, indígenas e pessoas com deficiência, percebeu-se a diferença de entendimento sobre o assunto entre os representantes dos setores públicos e privado. Nesse momento, surgiram as categorias cotas e qualidade da escola pública. Para um bolsista que respondeu à questão aberta do questionário,

[...] o ProUni ainda é uma política muito imediatista. Apesar de ajudar no ingresso ao ensino superior, não resolve a raiz do problema, que é a educação básica pública.O ProUni gera resultados rápidos, mas a longo prazo o investimento no programa talvez não seja a melhor opção se comparado a um investimento real em universidades públicas que poderiam ser mais amplas, mais acessíveis e, principalmente, com mais qualidade (B17 - informação verbal, grifos nossos).

Pelo entendimento da maioria dos sujeitos do setor privado, se todos tivessem acesso à escola de educação básica, de qualidade, não precisaria haver cotas, sobretudo as raciais. Em relação à reserva de vagas para negros, a discordância é bastante representativa. Alguns ainda defendem as cotas sociais, considerando renda e egressos da escola pública e, segundo eles, estariam aí incluídos também os negros. Portanto, a análise feita a partir dessa percepção é de que a relação entre o déficit na educação superior e a falta de escola pública, de educação básica de qualidade é diretamente proporcional.

[...] a diferença está no acesso, na estrutura da escola, na estrutura familiar, na estrutura da escola pública. Quem estuda na escola privada tem acesso à internet, ele tem acesso ao círculo dele de maior conhecimento cultural, [mais] acesso à informação do que escola pública. Não é o problema do aluno. Não é o problema de dizer assim: você pega esse aluno em uma escola pública e coloca em uma escola privada, o conhecimento dele e o envolvimento que ele tem junto com os outros ali, com acesso às informações, ele vai ter nota tão boa quem [já estudava] ali, então, esse é o 
problema [...] agora, a questão de você ser branco, preto ou pardo, isso é ridículo, nesse sentido. (GI1 - informação verbal, grifos nossos)

A fala desse gestor, de certa maneira, vai ao encontro ao que Bourdieu (2011) denomina de capital cultural. O autor também relaciona o desempenho do estudante à bagagem de conhecimento e de acesso à cultura que o mesmo tem, proveniente de seu meio familiar. Para ele,

[...] as disposições negativas no tocante à escola que levam a maioria das crianças das classes e frações de classe mais desfavorecidas culturalmente à auto-eliminação, como, por exemplo, a depreciação de si mesmo, a desvalorização da escola e de suas sanções ou a resignação ao fracasso e à exclusão, devem ser compreendidas em termos de uma antecipação fundada na estimativa inconsciente das probabilidades objetivas de êxito viáveis ao conjunto da categoria social, sanções que a escola reserva objetivamente às classes ou frações desprovidas de capital cultural (p. 310).

Somada à ausência desse capital cultural, está o acesso à escola pública, que não oferece as condições necessárias a uma boa formação, capaz de oportunizar ao indivíduo a garantia do acesso à universidade. Para o gestor, esse é um dos fenômenos que explica o problema no déficit relacionado ao ingresso na educação superior. Para ele, não há sentido em oferecer tratamento diferenciado aos negros, por meio de reserva de vagas, visto que o problema seria econômico e não racial.

Apesar de achar que o problema também está relacionado à dificuldade do Estado em oferecer escola de educação básica de qualidade, este gestor acredita que as cotas devem existir para acabar com as "distorções", mas que deveriam ser baseadas em critério de renda e não de raça. O mesmo diz:

[...] eu sou contra as cotas, mas também reconheço que elas devam existir, pelo menos até corrigir essas distorções do ensino de qualidade [...] eu acho que enquanto a gente não der um ensino realmente de qualidade, que permita efetivamente a democratização do ensino e a inclusão do ensino de qualidade pra todo mundo, infelizmente nós temos que conviver com cotas. Porque eu não vejo pra mim o maior problema é a falta de renda, eu acho que deveriam fazer alguma coisa pela faixa de renda, não por cor da pele[...] porque tem gente vivendo na miséria de olhos azuis e tem gente vivendo na miséria negro. Então, seria muito mais , acho que muito mais viável, acho que muito mais democrático, mas justo fazer por faixa de renda[...] (GI2- informação verbal, grifos nossos).

[...] em uma universidade federal eu acho que as pessoas são, devem ser vistas como iguais e acredito que isso foi um movimento que aumentou o racismo. Acho que os jovens terminaram virando uma brincadeira, falando: só está aqui por causa das cotas [...] e a questão da equidade não vê isso, essa 
coisa de dizer que o negro tem menos, acho que classe social sim, avaliar classe social pra dar chance maior pra essas pessoas, eu concordo plenamente, mas se você é negro, isso é um absurdo. (GI3 - informação verbal, grifos nossos).

Considerou-se relevante relatar essas falas porque, apesar de não referirem-se diretamente ao ProUni, a crítica pode ser assumida pelo programa, considerando que a lei que o instituiu prevê a reserva de vagas a esse grupo de pessoas. Portanto, percebe-se que há fortes resistências em aceitar essas ações afirmativas, por não reconhecerem que haja justificativa para focalizar o negro. Em geral, os entrevistados consideram que as cotas, se existirem, devem ser por critério de renda, independentemente de cor/raça.

[...] eu acho que seria mais uma cota voltada pra questão social, de acordo com o perfil social do estudante. Não com o perfil étnico ou com o perfil do biotipo sabe[...] tem que ser uma coisa assim, o meu grupo de cotistas são aqueles que não tinham condições de estudar em uma escola de ponta, mas que demonstram capacidade pra isso. Esse cara tem que ser estimulado, eu acho que a cota pela cota ela é jogada à plateia. O que eu acho também é que o programa de cotas [...] ele não deixa de ser um programa de democratização do acesso, que tem os seus méritos, até por romper paradigmas, então, eu acho que esse papel já está cumprido. (RIP informação verbal, grifos nossos).

Conforme já exposto, a reserva de vagas a partir do critério de raça e etnia está prevista na lei do ProUni, que determinou um percentual a esses estudantes, a partir do estabelecido pelo IBGE em relação à distribuição étnica-racial do país.

Art. $7^{0}$ As obrigações a serem cumpridas pela instituição de ensino superior serão previstas no termo de adesão ao Prouni, no qual deverão constar as seguintes cláusulas necessárias:

I - proporção de bolsas de estudo oferecidas por curso, turno e unidade, respeitados os parâmetros estabelecidos no art. $5^{\circ}$ desta Lei;

II - percentual de bolsas de estudo destinado à implementação de políticas afirmativas de acesso ao ensino superior de portadores de deficiência ou de autodeclarados indígenas e negros.

$\S 1^{\circ} \mathrm{O}$ percentual de que trata $o$ inciso II do caput deste artigo deverá ser, no mínimo, igual ao percentual de cidadãos autodeclarados indígenas, pardos ou pretos, na respectiva unidade da Federação, segundo o último censo da Fundação Instituto Brasileiro de Geografia e Estatística - IBGE. (BRASIL, 2005, grifos nossos).

No entanto, além dessa previsão, existe a chamada "Lei de Cotas" que trata de forma mais ampla do tema. A legislação dispõe sobre reserva de vagas aos egressos de escola 
pública, desses $50 \%$ deve atender a um critério de renda e ainda prevê cotas aos pretos, pardos e indígenas. A seguir, texto da referida lei, para melhor compreensão do assunto:

\begin{abstract}
Art. $5^{0}$ Em cada instituição federal de ensino técnico de nível médio, as vagas de que trata o art. $4^{0}$ desta Lei serão preenchidas, por curso e turno, por autodeclarados pretos, pardos e indígenas, em proporção no mínimo igual à de pretos, pardos e indígenas na população da unidade da Federação onde está instalada a instituição, segundo o último censo do Instituto Brasileiro de Geografia e Estatística (IBGE).

Parágrafo único. No caso de não preenchimento das vagas segundo os critérios estabelecidos no caput deste artigo, aquelas remanescentes deverão ser preenchidas por estudantes que tenham cursado integralmente o ensino fundamental em escola pública.

Art. $6^{-}$O Ministério da Educação e a Secretaria Especial de Políticas de Promoção da Igualdade Racial, da Presidência da República, serão responsáveis pelo acompanhamento e avaliação do programa de que trata esta Lei, ouvida a Fundação Nacional do Índio (Funai).

Art. $7^{\circ}$ O Poder Executivo promoverá, no prazo de 10 (dez) anos, a contar da publicação desta Lei, a revisão do programa especial para o acesso de estudantes pretos, pardos e indígenas, bem como daqueles que tenham cursado integralmente o ensino médio em escolas públicas, às instituições de educação superior. (BRASIL, 2012, grifo nosso).
\end{abstract}

Diferentemente do ProUni, a referida lei diz respeito às instituições federais de educação, de nível técnico (IFET) ou superior (IFES). Além disso, é importante observar que, em seu art. $7^{\circ}$, está prevista uma revisão da lei. Significa que, daqui dez anos, conforme estabelece a norma, espera-se que o país já tenha reduzido seus déficits educacionais considerando suas assimetrias socioeconômicas. Por isso, aos críticos das ações afirmativas do governo, vale a ressalva. Essas ações existem, apenas, como uma alternativa para superar determinada situação que se faz urgente devido ao seu aprofundamento. Portanto, não há quem duvide, por exemplo, que a educação básica de qualidade deveria ser um direito universal e que, com essa realidade, poderia prescindir-se das cotas, uma vez que todos seriam tratados de forma equânime.

Todavia, como já visto brevemente neste trabalho, o que prevaleceu no país foi uma postura elitizada dos governantes e até mesmo, de parcela da sociedade. Nesse sentido, não há como esperar que todo um sistema educacional seja remodelado para que essas assimetrias sejam superadas. Afinal, existem muitas pessoas, de diferentes idades ${ }^{75}$, que ainda sonham com um futuro melhor e, nesse sentido, o Estado tem obrigação de agir para que políticas públicas os alcancem.

\footnotetext{
${ }^{75}$ Não a toa que as matrículas nas IES são, em maior número, de pessoas com idade acima da ideal (18 a 24 anos).
} 
Ações emergenciais que contribuam para a conquista de mais equidade devem ser pensadas e implementadas. Quanto à discussão relacionada à inexistência de diferença cognitiva entre brancos e pretos e que por isso, as cotas não se justificam, vale pensar em que medida isso se traveste de simples argumento contra as cotas, desconsiderando a herança histórica para aqueles que delas se beneficiam.

Outra situação considerada importante por esta pesquisa foi a questão da democratização com garantia de acesso a cursos de alto custo e demanda. Quando perguntados sobre a contribuição do ProUni a esse fenômeno, os entrevistados foram unânimes em concordar com a importância do programa para a garantia desse ingresso. A legislação que dispõe sobre a referida política dispõe sobre o percentual de bolsas que a instituição deve ofertar, abrangendo todos os cursos em todos os turnos. Portanto, a IES que aderir ao programa deve obedecer a esta determinação. Então, independentemente da complexidade, demanda e custo do curso, a IES deve disponibilizar vagas dentro do percentual estabelecido e previsto pelo marco regulatório do programa. Caso contrário, como chamou a atenção um dos gestores entrevistados, se não houver garantia dessa proporcionalidade, deve-se atentar para uma possível irregularidade institucional. Segundo ele, se não tiver bolsistas do ProUni nos cursos de alta concorrência, como Medicina e Engenharia Civil (em instituições que os ofereçam) "tem algum tipo de irregularidade, porque a oferta de vagas tem que ser em todos os cursos e turnos, essa é a exigência [...]". Ele destaca, inclusive, a importância desse critério, para garantir o ingresso de bolsistas nesses cursos de alta complexidade e relata que "[...] nós temos prounistas formados em medicina, tem histórias emocionantes, eu tenho vídeos que eu posso te mostrar, são emocionantes, você chora de ver a história do cara" (GM1 - informação verbal). De acordo com a Lei ñ 11.096 de 2004 , em seu artigo $5^{\circ}$, a

[...] instituição privada de ensino superior, com fins lucrativos ou sem fins lucrativos não beneficente, poderá aderir ao Prouni mediante assinatura de termo de adesão, cumprindo-lhe oferecer, no mínimo, 1 (uma) bolsa integral para o equivalente a 10,7 (dez inteiros e sete décimos) estudantes regularmente pagantes e devidamente matriculados ao final do correspondente período letivo anterior,conforme regulamento a ser estabelecido pelo Ministério da Educação, excluído o número correspondente a bolsas integrais concedidas pelo Prouni ou pela própria instituição, em cursos efetivamente nela instalados (BRASIL, 2005, grifos nossos).

Destaca-se, a partir da leitura desse artigo, que não é uma escolha da instituição oferecer ou não vagas em cursos de alta demanda e custo. $\mathrm{O}$ mesmo ratifica a obrigatoriedade 
já ressaltada. A partir do momento em que a IES aderir ao ProUni, todos os seus cursos devem ter bolsas disponibilizadas, numa proporção de 1 (uma) bolsa integral para cada 10,7 pagantes. Em relação às bolsas parciais, essa proporção é de 1 (uma) para cada 22 estudantes regularmente pagantes. Reitera-se que a instituição pesquisada oferece apenas bolsas integrais. A seguir, relatos de outros entrevistados que entendem o programa como porta de acesso importante a esses cursos de alto custo, considerando a condição econômica familiar dos bolsistas.

Eu acho que da mesma forma que as licenciaturas, os alunos também foram beneficiados em relação a esses cursos, porque hoje ninguém teria cinco mil reais com um pai ganhando um salário mínimo, cinco mil pra pagar em um curso de medicina e a concorrência em uma instituição pública é muito grande. Então, eu acho que foram muito mais benefícios pra área de saúde, pra esses cursos de engenharia, cursos mais caros, muito mais benefícios para esses alunos [...] ]as licenciaturas é uma quantidade pouca de alunos que pedem bolsa ProUni [...] (GI4 - informação verbal, grifos nossos).

Eu acho que realmente foi muito útil nessa parte o ProUni foi um diferencial, abrindo as vagas para o ProUni acabou possibilitando o acesso a cursos de alta concorrência de alto custo através do ProUni. Acho que isso foi uma iniciativa muito boa do governo em termos de democratizar. Uma democratização feita em um programa sério que era do ProUni, até por próprio merecimento em termos de nota do aluno [...] dentro de critérios estabelecidos para democratização[...] (GI5 - informação verbal, grifos nossos).

Importante destacar a fala desse gestor, ao trazer à tona a questão do merecimento. Para ele, o programa valoriza essa variável. Nesse sentido, essa observação permite questionar a ideia de que o ProUni leva às IES alunos pouco preparados. Segundo o entrevistado, como o bolsista precisa atingir uma pontuação mínima no Enem, não há porque falar em aluno despreparado ou menos capaz. Em diversos momentos da entrevista, ele destacou o papel do merecimento como uma dimensão importante da política: "eu acho que é questão realmente de merecimento [...] O grande objetivo do ProUni acaba sendo realmente por merecimento do aluno" (GI5 - informação verbal). A seguir, outro relato acerca do acesso a cursos de alto custo e demanda, por meio do ProUni.

[...] outro dia estava conversando no restaurante com um aluno de medicina e do meu lado estava sentado um aluno que tem bolsa de $100 \%$, que veio da periferia, renda familiar de mil e poucos reais e hoje está estudando, fazendo curso de medicina, que custa cinco mil e poucos reais a mensalidade e ele está sem pagar nada. E ele preferiu vir para a (IES) ao invés de ir para a UnB. Falou por problema de greve, aquele negócio todo. Então, está estudando aqui, mas provavelmente, ele não 
conseguiria passar por outro meio pra uma universidade federal, teve um acesso lá pelo ProUni. Nesse contexto, ele contribuiu para que esse aluno de baixa renda tivesse acesso ao ensino superior em qualquer curso. (GI2 informação verbal, grifos nossos).

Ainda sobre esse tema e pensando no olhar dialético a que se propôs pautar-se esse trabalho, considera-se importante trazer o relato de uma gestora que questiona o caráter democratizante do programa, sobretudo em relação à renda e ao acesso de estudantes carentes nesses cursos de alto custo. Apesar de ser uma voz dissonante entre todos os entrevistados, acredita-se relevante expor sua percepção acerca desse fenômeno.

\footnotetext{
Olha, eu tenho a impressão, não tenho dados exatos para relatar, mas eu tenho a impressão que a grande maioria do pessoal do ProUni não era tão pessoal de baixa renda assim não. Eu acho que todos eles eram de classe média pra cima. Não sei se é porque o curso de [xxx] tem um pouco o padrão diferenciado, mas [...] o fator limitante não foi tanto o critério de renda, o fator limitante foi o Enem. Então, daquelas pessoas que passavam no Enem, depois do Enem, se tivesse a classificação "x" aí que ia ver o fator renda (GI3 - informação verbal, grifos nossos).
}

Ressalta-se que a primeira etapa para a seleção dos bolsistas ProUni é, de fato, a prova do Enem. Só depois de alcançada a nota que o elege ao curso de seu interesse que os demais critérios são analisados, incluindo aí, o de renda. Cabe à instituição verificar toda a documentação e comprovar sua veracidade. Não restam dúvidas de que haja fraudes, mas é fato que a referida política objetiva, a partir de critérios objetivos, privilegiar estudantes carentes. Em que pese às distorções, o perfil dos bolsistas aqui pesquisados demonstra que esse objetivo é alcançado.

Por fim, duas dimensões foram destacadas pelo Plano Nacional de Educação como possíveis contribuições do ProUni para a política de democratização do acesso à educação superior. A referida legislação atribui ao programa um dos meios para alcançar a qualidade e permanência do discente nos cursos de graduação. Vale destacar alguns relatos acerca do tema.

\subsection{O ProUni e as dimensões qualidade e permanência: os desafios da política}

Conforme disposto no PNE 2014, são grandes os desafios definidos por suas metas. Em relação à educação superior, essa afirmação toma mais corpo, considerando o fato de não se ter conseguido atingir o objetivo estabelecido no plano anterior. Significa dizer que, apesar 
dos esforços dos últimos anos, as políticas desse nível educacional não foram suficientes para atender ao previsto no referido plano, mesmo envolvendo amplamente o setor público e o privado, conforme descrito na meta 12 do PNE de 2014/2024.

Interessa nesta parte do trabalho analisar como pensam os entrevistados desta pesquisa sobre o papel do ProUni em relação à sua capacidade de atingir essa meta, considerando as dimensões qualidade e permanência, apesar dessa última não estar explicitada no texto. Várias são as estratégias definidas para o alcance do referida objetivo. Destaca-se, portanto, a de número 12.20 que prevê "ampliar, no âmbito do Fundo de Financiamento ao Estudante do Ensino Superior (FIES), e do Programa Universidade para Todos (PROUNI), os benefícios destinados à concessão de financiamento" (BRASIL, 2014).

Fica clara a intenção do Estado de manter o setor privado como parceiro para continuar com o processo de expansão e democratização do acesso à educação superior. Por isso, a questão que se levou aos sujeitos entrevistados da pesquisa foi: a partir das dimensões qualidade e permanência, de que maneira você acredita que o ProUni pode contribuir com as metas estabelecidas pelo PNE de 2014? Como respostas, por sua vez, vale destacar as que segue:

O PNE de 2014, ele tá muito ancorado em algumas políticas já existentes e que ele coloca para consolidar, aperfeiçoar no que se refere à avaliação. Ele diz: aperfeiçoar o Sistema Nacional de Avaliação. Então, ele demonstra que as políticas afirmativas, as políticas de inclusão, os apoios à permanência e também o reforço da qualidade são fundamentais para garantir o direito à educação (GM3 - informação verbal).

Ele é essencial, hoje realmente muita gente, eu acredito que 30\% hoje dos nossos alunos, eles estão distribuídos em ProUni, Fies, etc. Então, para esses meninos terem uma educação de qualidade, já que não tiveram oportunidade do estado federal (sic). Sem dúvidas, esse programa ajuda demais. A gente observa realmente neles uma alegria muito grande, muita gente que vem aqui "ai eu queria fazer um curso, mas eu queria conseguir um Fies ou conseguir um ProUni ou ter algum incentivo externo porque meus pais não dão conta de pagar". A gente conhece muitos casos desses, então sem dúvida alguma esse programa é essencial para manutenção de vários estudantes, realizando seu sonho com um curso superior (GI3 - informação verbal, grifos nossos).

Eu acho que é importante nos dois termos [...] acho que o ProUni pode ajudar tanto com qualidade como pode ajudar também na permanência deste aluno[...] tem estímulo realmente pra iniciar e terminar o curso e que seja realmente mantida a qualidade dele, todo esse processo de seleção do ProUni seja realmente feito em termos de merecimento do aluno, o aluno realmente merecer tá nesse curso então isso é importante de manter. [...] e o aluno tende a permanecer nos cursos. Acho que o aspecto mais importante que tem todas essas metas é o ProUni. O ProUni realmente mostra e dá oportunidade para esse aluno em alcançar cursos de maior complexidade (GI5 - informação verbal, grifos nossos). 
Bom, a questão de qualidade sempre foi levantada quando foi criado o ProUni. A ladainha é de que vai piorar a qualidade, todo mundo dizia isso aí. Cansei de ver coisas escritas por algumas personalidades que hoje tem cargos de liderança e que eram contra o ProUni lá no início, porque achavam que isso é uma universidade pra pobre de baixa qualidade. Mas a verdade é a seguinte, que, de todas as formas que você analisa, você chega à conclusão contrária. Os prounistas são alunos melhores do que os pagantes e os fiesistas. Enade após enade, nós confirmamos isso [...] em 2007, saúde agrária, os prounistas foram melhores em dez das dezesseis áreas avaliadas, 2010 eles foram melhores em todas as 18 áreas avaliadas [...] em 2012 em todas as áreas avaliadas, então não é coincidência, essa meninada se agarra à oportunidade e estuda e tem um critério também já de entrada de 450 pontos. A gente exige na entrada [...] 450 é o mínimo, [...] então ele só não estava na educação superior porque ele era pobre, não podia pagar. Agora ele não precisa pagar, tem oportunidade e se agarra de unhas e dentes pra poder aproveitar essa oportunidade. Eu acho que isso explica [...] já dá a sinalização, olha, tem que se preocupar com a qualidade. Aprenda! Estude! [...] os prounistas que entraram no setor privado já entram com um desempenho melhor. Posso dizer que o ProUni contribui pra melhoria da qualidade do curso, porque ele trás alunos melhores já na entrada [...] podemos dizer que o ProUni é um elemento que contribui pra melhoria da qualidade do setor privado (GM1 - informação verbal, grifos nossos).

A partir desses relatos, em que pese as diferentes interpretações acerca da mesma questão, infere-se que os sujeitos da pesquisa entendem que o ProUni pode contribuir com a meta estabelecida pelo novo PNE. Além disso, e mais destacado, é que consideram que o programa contribui para a qualidade da educação superior, seja no curso, seja na instituição. Tal conclusão se dá pelos relatos que abordam, sobretudo, a questão da pontuação de entrada desses bolsistas, o que já garante certa qualidade no desempenho desses. Para confirmar essa tendência valorativa, as avaliações do Enade ratificam a qualidade desses bolsistas, conforme destacou GM1.

Para finalizar a análise dos dados coletados por meio das entrevistas e do questionário, vale destacar duas falas que expõem as contradições e percepções divergentes, acerca da mesma questão. Ainda sobre o papel do ProUni junto às metas do PNE e as dimensões qualidade e permanência, o gestor público e o representante do setor privado, responderam da seguinte forma:

[...] eu acho que o grande mérito é isso, falar que uma instituição que vai aderir ao ProUni, ela tem que necessariamente ofertar as bolsas em todos os cursos e turnos. Ela não pode escolher aonde colocar os seus bolsistas. Esse é o mérito. $O$ único problema que está associado a isso, é que não tem um corte de qualidade, por exemplo. Então, essa instituição tem um curso mal avaliado, serão ofertadas bolsas do mesmo jeito, naquele curso mal avaliado. Esse é um dos questionamentos que se é feito [...] então, ele não diferencia a quantidade de bolsas ou a oferta de bolsas pela questão da 
qualidade, por outro lado, eu acho que muitos relatos que eu ouvi por aí [...] esses alunos do ProUni, eles têm colaborado pra questão da qualidade no curso [...] (GM2 - informação verbal, grifos nossos).

[...] é uma meta ambiciosa [do PNE], é uma meta que nos colocaria basicamente em um padrão de acesso de países bem mais desenvolvidos, padrão Chile, é por aí. Então, assim, pra que a gente consiga chegar, tem que rever os critérios do ProUni. Aquela questão do financeiro, acho que até tem que ser revisto, ou flexibilizado ou ampliado. Uma coisa que eu também considero fundamental é a gente ter políticas que assegurem a permanência. A questão hoje, o link do ProUni com qualidade, ele não pode oferecer nem bolsa no ProUni, nem vaga no Fies, que é o critério 3. A gente pode ter todas as críticas ao CPC e ao Enade, mas, assim, pelo menos se chegou a uma regra posta e conhecida do que seria qualidade para fins desses problemas públicos. Também se criou uma regra de qualidade para o outro lado [450 pontos para ingressante] embora os números hoje mostrem que a maior parte dos interessados, ou boa parte dos interessados está acima dessa régua de qualidade [...] (RIP - informação verbal, grifos nossos).

Ao analisar o conteúdo das entrevistas, assim como o questionário e respectivas respostas abertas dos bolsistas, foi construída uma visão geral acerca do papel no ProUni para a democratização do acesso à educação, assim como, sobre a forma que são percebidas as categorias aqui propostas. No entanto, a impressão que se tem mesmo é do quanto ainda há questões a serem abordadas e consideradas para reflexão.

\subsection{Proposta de Nota Técnica à Secretaria de Educação Superior - SESu e a possibilidade de incremento da Política}

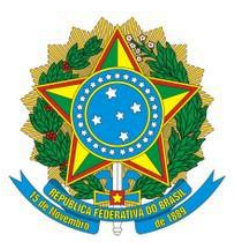

MINISTÉRIO DA EDUCAÇÃO SECRETARIA DE EDUCAÇÃO SUPERIOR DIRETORIA DE POLÍTICAS E PROGRAMAS DE GRADUAÇÃO COORDENAÇÃO-GERAL DE PROJETOS ESPECIAIS PARA A GRADUAÇÃO

\section{NOTA TÉCNICA N /2016-CGPEG/DIPPG/ SESU/MEC}

Ementa: apresentação de sugestões para realinhamento do Programa Universidade para Todos - ProUni, a partir de pesquisa desenvolvida no âmbito do Mestrado Profissional em Educação, realizada na Universidade de Brasília, por meio de uma parceria entre MEC e UnB. 


\section{INTRODUÇÃO}

1. Esta Nota Técnica é apresentada como um produto da dissertação produzida no âmbito do Programa de Pós-Graduação em Educação - Modalidade Profissional -, da Universidade de Brasília (UnB) em parceria com o Ministério da Educação (MEC), na Área de Concentração Gestão de Políticas e Sistemas Educacionais (GPSE). O título da dissertação é "O Programa Universidade para Todos - uma análise da democratização do acesso numa IES privada do Distrito Federal (2011 a 2015).

2. A pesquisa teve como objetivo analisar em que medida o Programa Universidade para Todos, como política pública de educação, vem contribuindo para a democratização do acesso à educação superior brasileira. Para tanto, tomou-se como referência quatro cursos de uma instituição privada de educação do Distrito Federal; e como recorte temporal o período de 2011 a 2015.

3. A apresentação desta Nota Técnica foi prevista nos objetivos específicos do trabalho. São eles: i) analisar a capacidade do programa em contribuir com a ampliação das taxas de escolaridade, promovendo a democratização do acesso ao nível superior, a partir do que foi definido pelo Plano Nacional de Educação (2014-2024); ii) identificar o perfil dos bolsistas para verificar a capacidade do programa em democratizar o acesso à educação superior, do que se infere a garantida do ingresso de grupos historicamente excluídos (pobres, negros, indígenas e pessoas com deficiência) dos cursos de graduação; iii) analisar o olhar dos gestores, no âmbito do Ministério de Educação (MEC), da instituição privada pesquisada e dos bolsistas em relação à capacidade do programa de promover a democratização do acesso à educação superior, com equidade; iv) apresentar Nota Técnica, com a síntese do que foi identificado pela pesquisa e com as possibilidades de incremento da política.

4. A presente Nota Técnica objetiva contribuir para a melhoria do ProUni, na medida em que, por meio da pesquisa em questão, foram identificados problemas e entraves que comprometem a política. Para tanto, esta NT foi dividida em três partes. A primeira apresenta o relatório, com um breve contexto acerca de alguns problemas identificados. A segunda parte propõe, a partir dos dados coletados pela pesquisa, pontos de realinhamento. E, por fim, faz-se a conclusão do documento, com a síntese da proposta.

\section{I - RELATÓRIO}


5. O Programa Universidade para Todos - ProUni é uma política gerida pela Secretaria de Educação Superior (Sesu) do Ministério da Educação que oferece bolsas integrais e parciais a estudantes carentes, em instituições de educação superior privadas, além de reservar vagas a negros, indígenas e pessoas com deficiência, de acordo com a Lei $\mathrm{n}^{\circ}$ 11.096 de 13 de janeiro de 2005. A referida legislação também dispõe sobre a possibilidade de professores da rede pública de educação básica realizarem uma licenciatura e trata da regulação das entidades beneficentes de assistência social na educação superior.

6. Tal programa surge num contexto em que governo decide ampliar o acesso à educação superior, conforme determinava o Plano Nacional de Educação de 2001, aprovado pela Lei $\mathrm{n}^{\circ} 10.172$, de 09 de janeiro de 2001. Dentre as metas estabelecida em seu texto, estava o alcance de $30 \%$ da taxa líquida (jovens de 18 a 24 anos) cursando uma graduação.

7. Dados estatísticos do $\mathrm{MEC}^{76}$ mostram que o ProUni contribuiu para a inserção de mais pessoas nas instituições de educação superior, considerando o número de bolsistas matriculados no período de 2005 a 2014. Foram 1.497.225 (MEC, 2015) alunos com bolsas integrais e parciais, dividindo-se em $70 \%$ e $30 \%$, respectivamente.

8. Já o novo Plano Nacional de Educação aprovado pela Lei $n^{\circ} 13.005$, de 25 de junho de 2014 estabeleceu como meta para os próximos dez anos o alcance do índice de $33 \%$ de jovens entre 18 e 24 anos cursando uma graduação.

\section{II - FUNDAMENTAÇÃO}

9. Apesar do avanço que vem sendo realizado nas últimas duas décadas para ampliar o acesso à educação superior, o Brasil ainda apresenta grande déficit, o que fica perceptível, sobretudo, quando é comparado a países centrais e até mesmo aos seus vizinhos do continente. Conforme estudo da Organização para a Cooperação e Desenvolvimento Econômico - $\mathrm{OCDE}^{77}$, o Brasil obteve uma média de $14 \%$ para a

\footnotetext{
${ }^{76}$ As informações estatísticas do Programa Universidade para Todos, assim como estudos realizados sobre o assunto, como o de Ristoff (2014) e Abraes (2014), apontam para essa tendência.

77 A OCDE é uma organização internacional que congrega 35 países. Dentre suas ações está a elaboração de estudos comparativos sobre política econômica, além da coordenação de políticas direcionadas aos seus membros e a outros países. Esses dados foram descritos na publicação "Education at a Glance: OECD Indicators", considerada " a principal fonte de informações relevantes e precisas sobre o estado da educação ao
} 
população de 25 a 64 anos que concluem a educação superior, índice bem abaixo dos $34 \%$ da população dos países participantes que seguem a mesma trajetória. O cenário brasileiro não se mostrou mais promissor, nem mesmo em relação aos países da América Latina: Chile (21\%), Colômbia (22\%), Costa Rica (18\%) e México (19\%) (OECD, 2015).

10. Diante dessa realidade, diferentes medidas foram tomadas, tais como: a abertura de novas instituições privadas de educação superior, com a diversificação institucional e de cursos; a expansão das IFES, por meio de programas como o Expandir ${ }^{78}$ e o Reuni ${ }^{79}$; o financiamento de vagas públicas em IES privadas, com a criação do ProUni e o incremento do Fies ${ }^{80}$; assim como a ampliação da oferta de cursos em EaD, tanto nas IES públicas $\left(\mathrm{UAB}^{81}\right)$ quanto privadas.

11. Todas essas ações contribuíram para que mais pessoas pudessem acessar cursos de graduação. No entanto, dados da Pnad 2014 mostram o quanto ainda é preciso avançar. Com um índice de 17,7 \% (IBGE, 2015) de jovens entre 18 e 24 anos cursando uma graduação, os índices de 33\% vão exigir ações articuladas, como a garantia do acesso universal dos jovens na educação básica e sobretudo no ensino médio, bem como políticas que garantam a continuidade da expansão de vagas nas instituições de educação superior.

12. A melhoria na qualidade da educação superior não pode ser pensada sem se considerar os níveis educacionais que a antecede, portanto, o PNE 2014/2024, prevê ações para a redução das assimetrias presentes no acesso e permanência de estudantes no ensino médio, as quais impactam no acesso aos cursos de graduação. As metas de números 3, 7 , 10 e 11 do referido PNE são direcionadas à educação básica, tanto ao ensino fundamental quanto ao médio, incluindo aí a educação profissional. Tais metas são seguidas de estratégias que atendam aos objetivos de melhorar os índices da educação superior. Afinal, pensar a educação básica é também pensar a educação superior e,

redor do mundo. [...] oferece dados sobre a estrutura, o financiamento e o desempenho de sistemas educacionais de 34 países membros [...]de alguns países parceiros e do G20" (OECD, 2016).

78 O Expandir - Programa de expansão da educação superior pública (2003-2006) objetivou expandir e interiorizar as universidades federais, pelo fato de elas estarem concentradas, sobretudo, nas capitais. (DUARTE, 2015).

${ }^{79}$ O Reuni objetivou ampliar o acesso e permanência de estudantes na educação superior. Para tanto, às instituições que aderissem ao Programa, seriam criadas condições para expansão física, acadêmica e pedagógica da rede federal de educação superior (BRASIL, 2007).

${ }^{80}$ O Fies é um Programa de financiamento a estudantes de graduação, em instituições não gratuitas, com avaliação positiva do Ministério da Educação. Em 14 de janeiro de 2010 o Programa foi alterado pela Lei $\mathrm{n}^{\circ}$ 12.202 (BRASIL, 2010), o que promoveu a ampliação de seu alcance.

${ }^{81}$ A UAB é "um sistema integrado por universidades públicas que oferece cursos de nível superior para camadas da população que têm dificuldade de acesso à formação universitária, por meio do uso da metodologia da educação a distância" (CAPES, 2016). 
consequentemente, as políticas de acesso e permanência nos cursos de graduação, tanto do setor público, quanto do privado.

13. O ProUni é uma política de acesso à educação superior, não obstante, em que pese o grande número de bolsas que já foram preenchidas por meio desse programa, conforme já citado, problemas com a qualidade da oferta e com a permanência dos estudantes configuram desafios a serem enfrentados.

14. Em relação à qualidade da oferta, apesar de ser a IES a responsável pelas características do curso que oferece e o MEC a instituição que regula, supervisiona e avalia, o estudante tem papel central nesse processo na medida em que participa da avaliação institucional por meio do Enade. Esse exame "tem como objetivo aferir o desempenho dos estudantes em relação aos conteúdos programáticos previstos nas diretrizes curriculares do respectivo curso de graduação, e as habilidades e competências em sua formação" e compõe um dos instrumentos do Sistema Nacional de Avaliação da Educação Superior Sinaes (INEP, 2016). Portanto, o referido exame deve exercer um instrumento que contribua, efetivamente, para a melhoria dos cursos e instituições.

15. Em relação à permanência do estudante, o problema centra-se na questão socioeconômica, não descartando o problema com o desempenho, o qual pode definir sua continuação ou não no curso. No entanto, a abordagem aqui feita diz respeito à capacidade financeira de se manter frequentando a IES, considerando custos com material, transporte e alimentação.

16. A bolsa permanência ${ }^{82}$ é uma das possibilidades que contribuem para a continuidade do estudante na IES até sua formação. O referido programa objetiva ajudar no custeio das despesas educacionais, no entanto, apenas os beneficiários de bolsas integrais têm direito.

17. Outras ações, como a possibilidade de realização de estágios em bancos, por meio de parceria realizada entre MEC e FEBRABAN ${ }^{83}$, apresentam-se como alternativa para contribuir com a permanência desses bolsistas nas IES, sendo, no entanto, insuficiente, conforme atesta o depoimento de parte dos bolsistas presente nesta pesquisa.

\footnotetext{
82 A Portaria Normativa no 19 de 14 de setembro de 2011, (BRASIL, 2011) do Ministério da Educação regulamentou o art. 11 da Lei $\mathrm{n}^{\circ} 11.180$, de 23 de setembro de 2005 que "autoriza a concessão de bolsas de permanência a estudantes beneficiários do Programa Universidade para Todos ” (BRASIL, 2005).

83 O Ministério da Educação e a Federação Brasileira de Bancos - FEBRABAN - firmaram Termo de Cooperação Técnica com o objetivo de implementar ações conjuntas, em âmbito nacional, pelos bancos privados, com o objetivo de destinar $10 \%$ de vagas de seus programas de estágio a estudantes participantes do ProUni (MEC, 2016).
} 
18. As Comissões nacional e locais de acompanhamento do ProUni - CONAP e COLAPs foram instituídas por portarias ministeriais ${ }^{84}$ em 2006 e 2009, respectivamente, com o objetivo de fiscalizar suas ações junto às IES, assim como de interagir com a comunidade acadêmica e sociedade civil, recebendo críticas, sugestões e denúncias. Nesse sentido, considera-se fundamental a utilização desses canais de comunicação e de interação entre governo, IES e bolsistas para o aprimoramento da política, pois esta é a forma mais eficaz de saber quais as possibilidades apresentadas pelo Programa, assim como a maneira que o beneficiário tem de expressar suas dificuldades e anseios.

\section{III - DAS CONCLUSÕES}

32. Diante do exposto, recomenda-se que o Sistema Nacional de Avaliação da Educação Superior (Sinaes) se consolide como uma política que garanta, efetivamente, a qualidade na oferta dos cursos de graduação.

33. Sugere-se que o Ministério da Educação, por meio da Secretaria de Educação Superior (Sesu), responsável pela gestão do ProUni, fortaleça o Programa de Bolsa Permanência, de modo que o alcance seja cada vez mais amplo. Ampliá-lo, alcançando os prounistas de bolsas parciais de $50 \%$ e $25 \%$, com cálculo de proporcionalidade para a concessão do benefício é um caminho a ser considerado.

34. Recomenda-se ainda a ampliação de parcerias para a oferta de estágios aos bolsistas do ProUni, contribuindo com a geração de renda e, logo, com a permanência do estudante até sua formação.

35. Faz-se necessário que políticas públicas sejam pensadas no âmbito do ensino médio, a fim de que os egressos desse nível educacional participem de processos seletivos, com garantias de boas notas. A utilização do Exame Nacional do Ensino Médio (Enem) para o ingresso em diversos programas de acesso à educação superior, como o ProUni, pode ser uma ferramenta de promoção da qualidade dos cursos de graduação.

\section{Luciana da Silva Castro}

84 A CONAP foi instituída pela Portaria no 301, de 30 de janeiro de 2006 (MEC, 2006), já as COLAPs tiveram sua instituição disposta pela Portaria no 1.132, de 2 de fevereiro de 2009 (MEC, 2009). 


\section{CONSIDERAÇÕES FINAIS}

Esta pesquisa teve o objetivo de analisar em que medida o Programa Universidade para Todos, como política pública de educação, vem contribuindo para a democratização do acesso à educação superior brasileira no período de 2011 a 2015 em uma instituição privada do Distrito Federal. Essa ocupa importante papel no cenário desse nível educacional na cidade.

Não foi possível identificar a IES, devido à recomendação da própria instituição, a qual, após submissão do projeto ao seu comitê de ética e pesquisa, indicou a supressão do nome, para que essa fosse preservada. Nesse sentido, reitera-se apenas que se trata de um estabelecimento de grande porte, com muitos cursos, incluindo pós-graduação e EaD e que, essas características contribuíram para que a mesma fosse escolhida como lócus deste trabalho.

Os sujeitos que participaram desta pesquisa estavam direta ou indiretamente ligados ao tema aqui proposto. Trata-se de gestores institucionais, incluindo aí dirigente administrativo e coordenadores dos cursos selecionados. No Ministério da Educação foram entrevistadas pessoas que lidavam com o ProUni, mais diretamente, na condição de diretor de políticas e programa de graduação da Sesu/MEC e funcionários que, apesar de serem de outras áreas, tangenciam com o assunto apresentado. Os beneficiários do Programa dos quatro cursos selecionados também foram ouvidos, assim como o representante da Aassociação Brasileira da Mantenedoras do Ensino Superior - ABMES que defende os interesses das instituições privadas desse nível educacional.

Ao pesquisar sobre o ProUni, inicialmente intencionava-se desvelar, única e exclusivamente, os impactos dessa política na vida dos bolsistas. Logo se percebeu, contudo, que a referida política envolvia questões mais abrangentes. Nesse sentido, um ponto que foi amplamente analisado neste trabalho diz respeito à relação entre os setores público e privado, estabelecida no âmbito do Estado e do governo. Além disso, viu-se também, ao longo do desenvolvimento da pesquisa, a necessidade de entender conceitos fundamentais para a compreensão do fenômeno que se pretendia entender. A equidade, como valor de justiça social, foi um deles, assim como a democratização e a expansão. Tais conceitos transformaram-se em categorias de conteúdo, por serem os pilares que explicariam e responderiam à pergunta central desta pesquisa: em que medida o Programa Universidade para Todos, como política pública, promoveu a democratização do acesso à educação superior em uma instituição privada do Distrito Federal nos anos de 2011 a 2015 ? 
Nesse sentido, algumas questões norteadoras foram elaboradas de forma a subsidiar e direcionar essa proposição: i) ao implementar programas como o ProUni, o Estado está furtando-se à responsabilidade de formular políticas que garantam o acesso e a permanência de estudantes em IES públicas, de qualidade?; ii) em que medida a definição e implementação do ProUni, pelo governo Luiz Inácio Lula da Silva, e sua continuidade no governo de Dilma Rousseff, seguiu a mesma lógica de estímulo ao setor privado, praticada pelo governo de Fernando Henrique Cardoso?; iii) como sustentar a tese de que a criação do ProUni contribuiu, ao mesmo tempo, para a democratização do acesso à educação superior, via setor privado, e para o aprofundamento da crise do setor público?; iv) em que proporção a continuidade do ProUni no governo Dilma Rousseff revela uma opção do Estado por manter esta política como protagonista na oferta desse nível educacional?

O ProUni é uma política impregnada de contradições, pois o simples fato de abranger dois setores comumente antagônicos já promove discussões divergentes. Entendido como uma parceria público-privada, o Programa contribui para a inserção de pessoas em instituições de educação superior em todo o Brasil. Entender de que maneira se dá esse processo, aliado às metas governamentais para a expansão do acesso à educação superior no país, foi um dos desafios desse trabalho.

A formação da sociedade brasileira é heterogênea em termos de cor/raça, classe social, econômica e formação cultural. No entanto, essa heterogeneidade não é replicada no campus da educação superior do país. A começar pelo déficit quantitativo, em relação à população com idade para cursar uma graduação (18 a 24 anos), outras questões se fazem presentes. A disparidade entre brancos e negros (pretos e pardos) cursando esse nível educacional e a prevalência dos mais ricos e brancos fazendo os cursos de maior custo e complexidade (RISTOFF, 2014) contribuem para a percepção de que a expansão do acesso à educação superior não foi acompanhada de uma preocupação com a minoração dessas características excludentes.

O ProUni surgiu num momento de forte demanda por vagas de educação superior, assim como aconteceu em outros períodos da história. Ademais, sua criação trouxe à tona o debate ideológico envolvendo o papel do setor privado para oferta de cursos desse nível educacional. Diante disso, percebeu-se a importância de se discutir essa questão tomando por base o que propõe a categoria metodológica da totalidade, pois se entendeu que a relação público-privada faz parte de um todo em que o ProUni está inserido, como parte dessa realidade que se constituiu em parceria. 
Por considerar o referido tema importante dentro do que propôs esse trabalho, outra categoria foi considerada para abordar esse fenômeno e outros aqui explicitados: a contradição. Ao optar por imprimir um olhar dialético a essa pesquisa, como prevê o materialismo histórico de Marx e Engels, intencionou-se revelar os movimentos contraditórios presentes nos discursos dos sujeitos envolvidos direta ou indiretamente com a política.

Além disso, sabe-se que a relação entre sujeito e objeto de um fenômeno social é mediada por diversas questões. Só para citar algumas, têm-se aquelas relacionadas à economia, à política e ou à cultura. Para analisar o contexto histórico em que o ProUni surgiu e se desenvolveu, buscou-se na mediação - entendida como categoria que estuda o conjunto das relações estabelecidas no âmbito dos fenômenos sociais e entre eles -, uma contribuição para explicar os sentidos e significados das vinculações existentes entre os diferentes sujeitos e o objeto pesquisado.

Apesar de não utilizar o método proposto pelo materialismo histórico dialético na sua essência, buscou-se nele uma inspiração, assim como algumas ferramentas metodológicas, a fim de imprimir um olhar pautado pelo movimento que pressupõe todo fenômeno histórico e social. Sendo assim, as citadas categorias metodológicas, em diálogo com as de conteúdo, construíram o arcabouço analítico para a compreensão do objeto proposto nesta pesquisa. Conforme explicita Kopnin (1978) na introdução de seu trabalho denominado: A Dialética como lógica e teoria do conhecimento, as

[...] categorias do materialismo dialético não só correspondem aos dados da ciência como ainda antecipam novos resultados, abrem amplas possibilidades para a criação científica e lhe indicam rumos promissores. A filosofia que apenas fixa antecipadamente aquilo que outras ciências alcançaram é supérflua e inútil, não pode desempenhar a função de método universal de conhecimento. A fonte da capacidade que têm as categorias filosóficas para antecipar os futuros resultados da ciência e assim ultrapassar, de certo modo, os limites dos resultados imediatos da ciência de sua época radica no fato de que essas categorias filosóficas surgem e se desenvolvem com base na generalização de toda a experiência do conhecimento e da reconstrução prática do mundo, de que nelas se realiza a síntese ( e não uma simples soma) do conhecimento derivado dos mais diversos campos da ciência. É essa síntese que gera novas idéias, à base das quais surge um novo enfoque dos fenômenos da realidade (p. 34, grifos nossos).

Nesse sentido, as categorias de conteúdo contribuem para a construção de uma nova percepção acerca do fenômeno pesquisado, no caso, a análise do quanto o ProUni está contribuindo para a democratização do acesso à educação superior numa IES do DF. Dito isso, foram pensadas, a priori, as categorias: expansão, democratização, equidade. A escolha 
se deu por entender que várias são as vertentes que explicam o processo de democratização do acesso à educação superior. Há quem entenda que no fenômeno da expansão está implícita a democratização; nessa está prevista a equidade; e a qualidade é condição sine qua non nos processos em que essas categorias estejam relacionadas. No entanto, ao analisar os conceitos dissociados dos fenômenos, verificam-se as divergências relacionadas ao seu entendimento. Por isso, decidiu-se transformar esses conceitos em categorias de conteúdo. Para Kuenzer (2011), essas categorias "são específicas para cada pesquisa e determinadas a partir de seus objetivos" (p. 66). No entanto, há outro modelo de categoria que é fundamental pra explicar as percepções dos sujeitos da pesquisa. São as que emergem da fala dos entrevistados, denominada de categoria a posteriori. No caso deste trabalho, foi a qualidade da educação básica que apareceu reiteradas vezes nas falas dos sujeitos. Diante disso, considerou-se fundamental abordar esse tema como ponto pacífico entre a maior parte dos entrevistados.

Esta pesquisa se propôs a abordar o fenômeno da democratização do acesso no período de 2011 a 2015 a partir do Programa Universidade para Todos, tomando como corpus uma IES do Distrito Federal. Para tanto, seu capítulo um analisou amplamente a relação estabelecido entre os setores público e privado, representados pelo Estado e instituições de educação superior. Apesar de ter buscado na história do Brasil a origem dessa parceria, perscrutando os primórdios, com a discussão sobre chegada dos jesuítas ao país e da primeira oferta privada de educação brasileira, a análise tornou-se mais aprofundada foi a partir do governo FHC. Na sequência, deu-se a comparação entre esse e a gestão de Lula, no que diz respeito à política de educação superior e o foco na iniciativa privada. Por fim, intencionou-se descrever os desafios de Dilma Rousseff, em seu segundo mandato, considerando que houve certa continuidade das políticas de seu antecessor, sobretudo em relação à parceria público privada, para a oferta de educação superior, concretizada pelo ProUni e ampliada pelo Fies. Pode-se considerar como novidade de política pública para esse campo, em seu governo, o Programa Ciências sem Fronteiras (CsF), que, conforme descreveu Borges (2015), a partir do decreto $^{85}$ que o instituiu, tinha como objetivo geral

[...] propiciar a formação e a capacitação de pessoas com elevada qualificação em universidades, instituições de educação profissional e tecnológica, e centros de pesquisa estrangeiros de excelência, além de atrair para o Brasil jovens talentos e pesquisadores estrangeiros de elevada qualificação, em áreas de conhecimento definidas como prioritárias (p.26).

\footnotetext{
${ }^{85}$ O Programa foi instituído pelo Decreto $n^{\circ}$ 7.642, de 13 de dezembro de 2011
} 
Apesar dessa novidade, o ProUni continuou configurando como destaque da política educacional de seu governo, por manter estável a oferta de vagas na educação superior, por meio de bolsas a um público carente, o qual, formado por minorias, carrega as marcas de um passado recente marcado pela exclusão e esquecimento do foco das políticas públicas.

Algumas perguntas já poderiam ser respondidas ao final desse capítulo. Todas as questões remetem à oferta de educação superior pela iniciativa privada. Tangenciando esse tema, destaca-se o estímulo a que ao setor fosse subsidiada política de continuidade de FHC, seguida por Lula e Dilma. Outro ponto que talvez possa ser pensado e colocado como reflexão é o que diz respeito à democratização do acesso e sua relação com o aprofundamento da crise no setor público. Por fim, cabe discutir em que medida o ProUni tornou-se uma opção do Estado por mantê-lo como protagonista na oferta de cursos de graduação no país.

Sem dúvida, o setor privado é uma realidade inquestionável e imprescindível para a oferta de educação superior, em todas as unidades da federação, na atual realidade brasileira. Esse modelo foi construído ao longo das décadas e se consolidou nos anos de 1960. A análise mais pormenorizada feita à luz dos governos FHC, Lula e Dilma, apresenta duas constatações. A primeira é a de que ambos os governos mantiveram o protagonismo do setor público na oferta desse nível de educação. No entanto, é necessário destacar o que os difere. Apesar de uma das políticas mais propagandeadas dos governos Lula e Dilma contar, justamente, com a parceria do setor privado, foi o setor público que mais contou com investimento dos respectivos governos, com programas como o Expandir e o Reuni - ambos voltados à expansão e interiorização das IFES, bem como ao investimento no setor.

A despeito do modelo privado de oferta de vagas na educação superior prevalecer, os dois últimos governos também implementaram ações que contemplaram as universidades federais. Portanto, em que pese as críticas relacionadas ao ProUni, sobretudo no que diz respeito à opção de manter o protagonismo do setor privado, não há que se falar em eximirem-se de formular políticas direcionadas ao setor público. É certo, como os dados, explanados ao longo deste trabalho, mostraram, que a superioridade da participação privada em relação à oferta de vagas é infinitamente maior.

O ProUni foi, sem dúvida, uma política que fortaleceu e estimulou o setor privado, tanto no governo Lula quanto no de Dilma. Nesse sentido, pode-se dizer que as gestões desses presidentes seguiram a lógica privatista empreendida pela administração de FHC. Não obstante, a discussão acerca do programa não pode esgotar-se nessa perspectiva. É preciso perceber os impactos que a referida política tem na vida das pessoas e, consequentemente, no cenário educacional do país. 
Embora este trabalho tenha sido um estudo de caso e que, portanto, tenha contado com uma amostra reduzida de sujeitos colaboradores, ao analisar os dados coletados por meio dos questionários aplicados aos beneficiários do programa e tendo como base o perfil dos bolsistas, depreende-se que o objetivo de alcançar uma população carente é atingido. Dos 66 alunos que participaram da pesquisa, 38, o que corresponde a 57,60\%, têm renda familiar de até dois salários mínimos e meio. Outra característica apresentada pelos referidos dados é que $45,40 \%$ dos estudantes que responderam à pesquisa informam terem utilizado o critério de ação afirmativa, prevista na lei que dispõe sobre o programa. A partir disso, se infere que a democratização, entendida como inclusão dos negros nas IES, é, em certa medida, alcançada, mesmo que esse movimento ainda não tenha promovido a correspondente representatividade racial da população brasileira.

Conquanto haja avanços promovidos pelo ProUni, as contradições inerentes a esse não podem e não devem ser ignoradas, visto que suas ações despertam, naturalmente, posições contrárias à expansão do setor privado. Ao mesmo tempo em que a política em questão se imbui de um caráter democratizante, ainda gera a preocupação em relação a sua capacidade de contribuir com a oferta de uma educação de qualidade. A garantia dessa última é que permitirá que a formação educacional se traduza em instrumento real de inclusão, seja no âmbito profissional, acadêmico e ou social, convertendo-se em um meio de se alcançar a emancipação individual.

Aos críticos do programa, diversas são as razões que impedem o ProUni de capacitar o cidadão a conquistar as referidas dimensões. Para esses, apenas o setor público é capaz de oferecer condições que viabilizem essas conquistas. No entanto, algumas respostas abertas demonstram o contrário, como mostra o aluno, na fala reportada a seguir:

[...] eu não teria a oportunidade de cursar o Ensino Superior senão por meio do programa. Acho que o programa é um dos melhores já criados pelo governo, já que abre caminho para jovens e até mesmo adultos a terem a oportunidae de crescerem profissionalmente, muitos desses alunos, não por não desejarem [...] não poderiam cursar o Ensino Superior em uma universidade pública. O ProUni abre uma gama de possibilidades de escolhas e assim posso optar por uma instituição que julgo ser melhor pra mim, que é mais perto da minha casa ou que pode oferecer mais benefícios pra minha vida profissional. Quando elogio o programa não o faço partindo de um ponto de vista partidário ou coisa parecida, o faço pois sei que ele dá oportunidades aqueles que aos olhos da sociedade não teriam a capacidade de ingressar no ensino superior, o faço porque assim como os meus colegas também bolsistas, recém saídos do Ensino Médio e sem nenhuma renda própria estou tendo a oportunidade de concretizar um desejo que talvez alguns anos atrás não poderia. A intenção não é abusar de sentimentalismo ou sensacionalismo, mas expressar que ele tem contribuído, a meu ver, com 
o desenvolvimento do país e para que jovens, independente de suas origens ou situações financeiras, tenham o "privilégio" de crescer intelectualmente. Somente a educação pode mudar o cenário do nosso país, somente por meio dela posso deixar de ser SOMENTE a filha do trabalhador rural e da diarista ou do pedreiro e da cozinheira que conseguiu bolsa e assim me tornar uma jovem (sem estereótipos) que escreve e determina seu próprio futuro (B10 informação verbal).

Para outro (a) bolsista, o programa garantiu sua chance de cursar uma graduação. Ao avaliar a política, ele disse: "Sinceramente, não tenho críticas, somente agradeço, pois sem o ProUni jamais teria condições financeiras de fazer uma faculdade (B24 - informação verbal)". Nessa mesma linha, este (a) bolsista (a) foi sucinto (a) em sua análise ao dizer que a política é “maravilhosa. Me deu a oportunidade de ter ensino superior, não poderia ser melhor!!” (B37 informação verbal).

Entretanto, conforme proposto neste trabalho, os limites e contradições da política devem ser expostos. Assim, apesar dos gestores explicitarem essas características, ninguém melhor que o próprio beneficiário do programa para jogar luz aos problemas evidenciados. Responderam ao questionário 66 estudantes, em um universo de 226 enviados. Dentre os que encaminharam respostas, cinco elogiaram o programa - conforme visto em alguns relatos aqui citados -; os demais contribuíram com críticas e sugestões. Alguns assuntos foram recorrentes como, por exemplo, a questão do auxílio permanência, em que seis alunos questionaram sua efetividade. A queixa girou em torno da falta de transparência e informação quanto ao assunto, devido à falta de divulgação. Outra crítica diz respeito à redução do alcance desse auxílio. Consideram a política insuficiente para atender a todos que precisam, tanto em termos de quantidade, quanto de qualidade (valor). A seguir, mostram-se alguns relatos nessa direção. "Transparência. Não sabia do Bolsa Permanência ProUni. Poderia ter sido oferecido quando me inscrevi”" (B02 - informação verbal).

[...] o que estraga o ProUni é a falta de compromisso em relação à bolsa permanência. Tem vários alunos que se mantém através dessa bolsa, pagam aluguel, água, luz e alimentação. Todos os meses vejo o desespero deles $\mathrm{n}$ grupo do Prouni e ligo para o MEC para saber quando sai a bolsa. O valor da bolsa também não ajuda quem está longe de casa, passar o mês com 400,00 deve ser bem difícil. (B20 - informação verbal).

Dois (duas) bolsistas se posicionaram da seguinte forma em relação à questão da permanência: "Como é um programa voltado para pessoas de baixa renda, existem materiais que tornam-se caros e comprometem a permanência, rendimento e autoestima para prosseguir em determinados momentos" (B21 - informação verbal). O (a) outro (a) bolsista questionou: 
"o que adianta ter cursos de altos valores se não conseguimos nos manter [sic]” (B33 informação verbal).

Outros assuntos recorrentes estiveram relacionados ao número de vagas insuficientes, aos critérios de seleção considerados injustos devido a fatores como renda, limite no número de bolsas usufruídas, maior transparência, menos burocracia, investimento na universidade pública, mais avaliação do programa e apoio pedagógico ao bolsista devido ao seu déficit na formação. A seguir, ilustram-se algumas falas que mostram as referidas críticas e sugestões.

Penso que o critério adotado atualmente para a concessão ou não da bolsa (integral ou parcial) é falho. Deveria ser levado em consideração o valor da mensalidade do curso pleiteado. Estipular apenas uma determinada faixa de renda familiar acaba por provocar alguns absurdos, a meu ver. Por exemplo, um aluno que ultrapasse por pouco o limite estipulado para a concessão da bolsa parcial teria condições de pagar uma mensalidade de 1.000,00 (um mil) reais de um curso de administração, por exemplo. Porém, talvez não teria condições de pagar 5.000,00 (cinco mil) reais mensais em um curso de medicina. (B04 - informação verbal).

Este (a) questiona a questão da transparência, ao propor "minimizar, o quanto possível, as fragilidades na fiscalização dos critérios de seleção do ProUni (B11 - informação verbal). Concernente aos critérios de reprovação/aprovação este (a) aluno (a) diz:

[...] no meu ponto de vista, essa política é muito injusta tendo em vista o déficit que nós alunos da rede pública tivemos (em relação a baixa qualidade no ensino público). De certa forma o aluno bolsista do ProUni tem baixa renda e na maioria das vezes tem que trabalhar para ajudar em casa, com isso tem pouco tempo para revisar, aprender e buscar meios de suprir o déficit herança [sic] da baixa qualidade de ensino da rede pública, sendo assim os bolsistas do prouni deveriam ter mais incentivo (ajuda) e não punição (B07 informação verbal).

Em que pese a legitimidade dessa crítica, e considerando a necessidade de ampliação do número de prounistas à bolsa permanência, assim como ao apoio pedagógico promovido pela IES, pesquisa da Abraes (2014) mostra que os beneficiários de bolsa integral do ProUni tem desempenho melhor no Enade do que a média nacional e superior aos dos alunos de instituições públicas de educação superior. Embora as condições socioeconômicas sejam desfavoráveis, como destacou B07, a referida pesquisa mostrou que

[...] o aluno bolsista Prouni na rede privada é capaz de compensar sua desvantagem social com base no esforço individual e na qualidade do ensino 
que recebe, dedicando-se ao programa e obtendo um resultado, na média, superior ao dos alunos da rede pública e muito superior à média nacional (ABRAES, 2014, p. 25).

Por fim, outra preocupação relatada pelos bolsistas, foi relacionada ao processo de seleção do programa. Para B35, falta "uma seleção mais rigorosa, onde minimize as possibilidades de fraudes no processo de seleção e comprovação de informações" (informação verbal). Para este outro (a) aluno (a) é preciso "minimizar o quanto possível as fragilidades na fiscalização dos critérios de seleção do Prouni” (B11 - informação verbal).

Portanto, esses foram os principais pontos abordados pelos estudantes, sujeitos da pesquisa. Considerou-se necessário expor tais relatos para que as contradições fossem expostas, assim como os limites do programa.

O capítulo dois abordou o ProUni sob a perspectiva da democratização do acesso à educação superior. Para tanto, sugeriu-se identificar quais os conceitos estavam por trás desse fenômeno. Daí a escolha das categorias de conteúdo: expansão, democratização, equidade e qualidade, pois se entende que essas se inter-relacionam de maneira a promover, verdadeiramente, a inclusão dos mais necessitados na educação superior.

A partir dos dados que revelaram as assimetrias presentes na sociedade brasileira, em relação ao acesso aos cursos de graduação, identificou-se que o ProUni contribuiu para a redução das desigualdades e para a ampliação e expansão da oferta de vagas, assim como do número de matrículas no nível superior. No entanto, apesar dos avanços, a democratização do acesso, como entendida neste trabalho, ainda precisa avançar, pois nos bancos das IES prevalecem os brancos, enquanto os mais abastados encontram-se, sobretudo, nos cursos de alto custo e demanda.

No entanto, vale destacar que, dentre os bolsistas que responderam à pesquisa (66), $71,20 \%$ são negros (pretos e pardos), muito acima da representação de cor e raça em âmbito nacional. Desses bolsistas, 45,50\% cursam engenharia civil e 15,10\% medicina, ou seja, mais da metade dos entrevistados estão em cursos de alto custo e demanda. Isso também caracteriza que essa IES privada do DF está conseguindo, por meio do ProUni, contribuir para que estudantes de baixa renda possam cursar essas graduações.

Ainda nesse capítulo, pretendeu-se demonstrar de que maneira o Programa Universidade para Todos pode contribuir para o atingimento da meta estabelecida pelo novo PNE, referente à ampliação e expansão da educação superior, até 2024. Considerando as dimensões qualidade - última categoria abordada - e permanência, os principais desafios no setor, concluiu-se que não há como prescindir dessa política e, consequentemente, do setor 
privado, para aumentar os índices educacionais definidos pelo plano. O grande desafio reside, justamente, na busca pela qualidade, pois, para Dias Sobrinho (2010b), não há democratização sem considerar essa dimensão. Oliveira (2013) chamou de "pseudodemocratização" a oferta de educação que prescinde da qualidade.

A categoria escolhida a posteriori emergiu da fala de vários entrevistados. Muitos consideram que a qualidade da educação básica é a solução para os problemas educacionais de todos os outros níveis. Alguns alunos também abordaram esse tema e destacaram a importância dessa fase para a formação do indivíduo e, consequentemente, para o acesso à educação superior. Não há como discordar dessa posição, no entanto, devido às assimetrias históricas, presentes na sociedade brasileira, não há como prescindir de políticas que reduzam esses déficits, assim como de ações afirmativas que contribuam para esse movimento.

A abordagem acerca da educação superior privada no Distrito Federal fechou o capítulo 2 destacando a lógica que o governo Lula imprimiu à expansão regional desse nível educacional. Segundo Sousa (2004), no

[...] contexto do Distrito Federal, o segmento do ensino [sic] superior privado mostrou-se bastante diversificado. Efetivamente, as instituições que o compõe são distintas em termos de propostas, vocações, marcas, produtos e serviços que possibilitam o atendimento à demanda - ainda que parcial - a um nível de ensino que o Estado não consegue prover (p. 84).

Apesar de o texto ser de 2004, portanto, segundo ano do governo Lula, as considerações do autor continuam atuais, pois sua análise descreve com clareza o modelo de educação superior que ainda prevalece na região. Com forte hegemonia do setor privado, as instituições competem entre si e disputam discentes como se estivessem atrás de consumidores para seus produtos. A visão mercadológica está muito presente e, com isso, a preocupação com a qualidade da oferta dos cursos de graduação, se apresenta como uma questão bastante relevante.

Ao responder à questão relativa ao papel do ProUni para se alcançar a meta estabelecida pelo PNE de 2014, considerando as dimensões qualidade e permanência, um dos gestores da IES pesquisada considera que o programa pode contribuir para o controle da qualidade dos cursos. Segundo ele,

[...] o próprio controle que eles fazem de aproveitamento dos estudos dos alunos já contribui para a qualidade. Por exemplo, o aluno que não consegue aprovação em determinada disciplina pode correr o risco de perder a bolsa, então ele já se preocupa em se envolver com atividades do curso, em se 
envolver com as disciplinas, os conteúdos pra conseguir atingir essa meta e manter a bolsa. Então, a própria administração das bolsas do programa já ajudam um pouco nessa qualidade [...] e eu acho que junto a isso, os programas de avaliações das instituições superiores, pra garantir essa qualidade, essa permanência dos alunos, que o governo também acompanhe a qualidade do ensino. O que esses bolsistas estão recebendo, então a gente sabe que tem vários tipos de avaliações, não só do conhecimento desses estudantes do ensino superior, quanto das instituições. Mas eu acho que o MEC tem que ficar atento a isso para que a gente consiga garantir. Numa instituição privada bem estruturada e já com um tempo no mercado, você acompanha esse processo, mas uma instituição que abre e fica dois anos e fecha, que foi a quantidade, consequência do governo Fernando Henrique Cardoso [sic]. Nós tivemos mais de 50 instituições privadas. (GI4 informação verbal).

A partir dessa fala e considerando outros relatos descritos ao longo do trabalho, não restrito a essa parte final, conclui-se que há um entendimento comum de que o ProUni pode contribuir para o alcance da meta estabelecida de 33\% de jovens, entre 18 a 24 anos, cursando uma graduação, até 2024. A partir dessa constatação e de outras considerações e análises realizadas a partir da triangulação de fonte de dados, proposta por esta pesquisa, pode-se concluir que tanto o objetivo geral quanto os específicos, foram alcançados.

O diálogo realizado entre as entrevistas, os dados dos questionários, os documentos e o referencial teórico foi fundamental para que o tema fosse amplamente discutido e abordado a partir de diferentes percepções, como prevê o olhar dialético direcionado aos fenômenos sociais.

Nesse sentido, pode-se dizer que o Programa Universidade para Todos, vem contribuindo para a democratização do acesso à educação superior, considerando tal fenômeno a partir do seu desdobramento em uma instituição do Distrito Federal. Ressalta-se, portanto, a importância do entendimento das dimensões que revestem essa categoria. É crucial para esta pesquisa a compreensão de que expandir significa ampliar, mas que democratizar significa incluir. O que se deseja é a democratização com equidade, ou seja, é a inclusão ampliada, com foco na redução das assimetrias e na ampliação de direitos.

Nesse sentido, considera-se necessário colocar ao lado da busca pelo equilíbrio econômico, ações que garantam também o equilíbrio social, com a garantia de equiparação de direitos e redução das desigualdades. Para isso, faz-se necessária forte atuação do Estado, com políticas públicas focalizadas. A discussão que envolve o papel do setor privado para a oferta da educação superior deve ser superada, por isso, há de se avançar para outro pleito. Não que esta pesquisa defenda a hegemonia absoluta e irrestrita do setor privado em detrimento das instituições públicas. O que se propõe é um debate em que se busque ampliar os direitos 
sociais, pautados pela preocupação com a qualidade da oferta e com a permanência do aluno na IES, até sua formação. Deve-se ter a preocupação com a verdadeira democratização, em que todos tenham direitos iguais, mas atendidas as particularidades de cada indivíduo.

O que não deve ser aceito é a democratização falseada. O que não pode acontecer é a ampliação pela ampliação. É a oferta de algo qualquer para alguém qualquer. É para essa direção que o Estado brasileiro precisa nortear sua agenda política. A superação das iniquidades precisa ser alcançada. Uma sociedade cuja população tem seus direitos respeitados e onde o Estado elabora políticas para o alcance desse objetivo, conquista uma condição em que políticas afirmativas deixam de ser necessárias e, daí, as cotas, tão mal entendidas, passam a ser lembradas apenas como um meio que conduziu a sociedade a um patamar de dignidade e cidadania.

Os diversos temas que tangenciaram essa pesquisa contribuíram para a ampliação do debate, mas podem indicar caminhos para outras pesquisas, pois diversos são os desafios que envolvem o assunto. Dentre os principais, está o desafio da democratização do acesso à educação superior, com garantia da permanência e da qualidade da oferta. Além disso, conhecer o perfil do concluinte que usufruiu a bolsa do ProUni faz-se fundamental para saber em que medida a política mudou a vida dessa pessoa. Afinal, ao buscar um diploma de nível superior, o estudante busca dentre outras coisas, qualificação para o mercado de trabalho, o que não é demérito algum. Apesar de se defender a formação proporcionada por uma universidade pública e se considerar fundamental seu papel para o desenvolvimento do país, não é possível aceitar a dicotomia público-privada. O que se faz preciso buscar são alternativas pelas quais o indivíduo possa fazer escolhas certamente respaldadas pela qualidade, permanência e equidade. 


\section{REFERÊNCIAS}

ABRAES, Associação brasileira para o desempenho da educação superior. Instituições particulares de ensino superior e ProUni: o impacto do programa de inclusão sobre o desempenho de seus alunos no Enade. 2014. Disponível em: 〈abraes.org>. Acesso em: $10 \mathrm{fev}$ de 2015.

ALMEIDA, M. A. Universidade para todos: o ProUni na visão dos bolsistas de uma instituição de ensino superior. 2009. 120 f. Dissertação (Mestrado em Educação) - Centro de Ciências Sociais Aplicadas, PUC - Campinas, Campinas.

AMARAL, Nelson Cardoso. O novo PNE e o financiamento da educação no Brasil: os recursos como um percentual do PIB. [SRB], 2013.

AMARAL, Daniela Patti do; OLIVEIRA, Fátima Bayma de.O prouni e a conclusão do ensino superior: novas trajetórias pessoais e profissionais dos egressos. In Ensaio: Avaliação Políticas Públicas Educação. Rio de Janeiro, v. 19, n. 73, p. 861-890, out./dez. 2011. Disponível em: <http://search.scielo.org/?q=prouni\&where=ORG〉. Acesso: 15 mar 2014.

ARRUDA, Ana Lúcia Borba de. Políticas da Educação Superior no Brasil: Expansão e Democratização: Um debate contemporâneo. Espaço do Currículo, v.3, n.2, pp.501-510, Set de 2010 a Mar de 2011.

Disponível em < http:// periodicos.ufpb.br/ojs2/index.php/rec>. Acesso: 25 out 2014.

AZEVEDO, Mário Luiz Neves de. Igualdade e equidade: qual é a medida da justiça social? Avaliação, Campinas; Sorocaba, SP, v. 18, n.1, p. 129-150, mar. 2013.

BIANCHETTI, Roberto G. Modelo Neoliberal e Políticas Educacionais. São Paulo : Cortez, 1997.

BONETI, Lindomar Wessler. Políticas públicas por dentro. Editora Unijuí. Ijuí, 2007.

BORGES, Rovênia Amorim. A interseccionalidade de gênero, raça e classe no Programa Ciência sem Fronteiras: um estudo sobre estudantes brasileiros com destino aos EUA. 2015. 215p. Dissertação (Mestrado -Mestrado Profissional em Educação) - Universidade de Brasília, Programa de Pós-Graduação em Educação, Brasília, 2015.

BOTO, Carlota. A dimensão iluminista da reforma pombalina dos estudos: das primeiras letras à universidade. Revista brasileira de educação. v. 15, n. 44, mai./ago. 2010.

BOURDIEU, P. A economia das trocas simbólicas. 7. ed. São Paulo: Perspectiva, 2011. p. 295-313

BRASIL. Constituição (1891). Constituição da República dos Estados Unidos do Brasil. Rio de Janeiro, RJ, 24 de fevereiro de 1891. Disponível em <www.planalto.gov.br/ccivil_03/Constituicao/Constituicao91.htm> Acesso: 17 nov 2015.

Constituição (1967). Constituição da República Federativa do Brasil. Brasília, DF, 24 de janeiro de 1967. Disponível em <www.planalto.gov.br/ccivil_03/Constituicao/Constituicao67.htm> Acesso: 18 out 2015. 
Constituição (1988). Constituição da República Federativa do Brasil. Brasília, DF, 05 de outubro de 1988.

Disponível em <www.planalto.gov.br/ccivil_03/constituicao/constituicaocompilado.htm>. Acesso: 13 nov 2014.

Decreto n. 8.659, de 05 de abril de 1911. Approva a lei Organica do Ensino Superior e do Fundamental na Republica. Diário Oficial da União, Rio de Janeiro, RJ, 06 de abril de 1911. Disponível em <www2.camara.leg.br/legin/fed/decret/1910-1919/decreto-8659-5-abril1911-517247-publicacaooriginal-1-pe.html>. Acesso: 14 nov 2015.

.Lei n. 4.024, de 20 de dezembro de 1961. Fixa as Diretrizes e Bases da Educação Nacional. Diário Oficial da União, Brasília, DF, 24 de dezembro de 1961 e retificado em 25 de dezembro de 1961. Disponível em <www.planalto.gov.br/CCIVIL_03/leis/L4024.htm> Acesso: 20 set 2015.

.Lei n. 5.540, de 28 de novembro de 1968. Fixa normas de organização e funcionamento do ensino superior e sua articulação com a escola média, e dá outras providências. Diário Oficial da União, Brasília, DF, 29 de novembro de 1968. Disponível em <www2.camara.leg.br/legin/fed/lei/1960-1969/lei-5540-28-novembro-1968-359201publicacaooriginal-1-pl.html> Acesso: 25 set 2015.

.Lei $n^{\circ} 9.394$ de 20 de dezembro de 1996. Estabelece as Diretrizes e Bases da Educação Nacional. Diário Oficial da União, Brasília, DF, 23 de dezembro de 1996. Disponível em<www.planalto.gov.br/ccivil_03/leis/19394.htm> Acesso em: 17 mar 2014.

Decreto n. 2.207, de 15 de abril de 1997. Regulamenta, para o Sistema Federal de Ensino, as disposições contidas nos arts. 19, 20, 45, 46 e $\S 1^{\circ}$, 52, parágrafo único, 54 e 88 da Lei no 9.394, de 20 de dezembro de 1996, e dá outras providências. Diário Oficial da União, Brasília, DF, 16 de abril de 1997. (1997a) Disponível em <www.planalto.gov.br/ccivil_03/decreto/D2207impressao.htm> Acesso: 14 dez 2015.

.Decreto n. 2.306, de 19 de agosto de 1997. Regulamenta, para o Sistema Federal de Ensino, as disposições contidas no art. 10 da Medida Provisória ${ }^{\circ}$ 1.477-39, de 8 de agosto de 1997, e nos arts. 16, 19, 20, 45, 46 e $\S 1^{\circ}, 52$, parágrafo único, 54 e 88 da Lei $n^{\circ} 9.394$, de 20 de dezembro de 1996, e dá outras providências. Diário Oficial da União, Brasília, DF, de 20 de agostode1997. (1997b)

Disponível em <www.planalto.gov.br/ccivil_03/decreto/D2306impressao.htm>. Acesso:14 $\operatorname{dez} 2015$.

.Lei n. 10.172 de 9 de janeiro de 2001. Aprova o Plano Nacional de Educação e dá outras providências. Diário Oficial da União, Brasília, DF, 10 de janeiro de 2001. (2001a) Disponível em <www.planalto.gov.br/ccivil_03/leis/leis_2001/110172.htm>. Acesso: 13 ago 2014. 
.Lei n. 10.260, de 12 de julho de 2001. Dispõe sobre o Fundo de Financiamento ao estudante do Ensino Superior e dá outras providências. Diário Oficial da União, Brasília, DF,de 13 de julho de 2001. (2001b) Disponível em <www.planalto.gov.br/ccivil_03/leis/LEIS_2001/L10260.htm>. Acesso: 17 fev 2016.

.Lei n. 10.861, de 14 de abril de 2004. Institui o Sistema Nacional de Avaliação da Educação Superior - SINAES e dá outras providências. Diário Oficial a União, Brasília, DF, 15 de abril de 2004. (2004a) Disponível em

<www.planalto.gov.br/ccivil_03/_ato2004-2006/2004/lei/110.861.htm>. Acesso: 08 mar 2016.

.Medida Provisória n. 213, de 10 de setembro de 2004. Institui o Programa Universidade para Todos - PROUNI, regula a atuação de entidades beneficentes de assistência social no ensino superior, e dá outras providências. Diário Oficial da União, Brasília, DF 13 de setembro de 2004. Retificado, 27 de setembro de 2004. (2004b) Disponível em <www.planalto.gov.br/ccivil_03/_ato2004-2006/2004/Mpv/213.htm>. Acesso em:16 out 2014.

.Decreto n. 5.245, de 15 de outubro de 2004. Regulamenta a Medida Provisória $\mathrm{n}^{\mathrm{o}}$ 213, de 10 de setembro de 2004, que institui o Programa Universidade para Todos PROUNI, regula a atuação de entidades beneficentes de assistência social no ensino superior, e dá outras providências. Diário Oficial da União, Brasília, DF, de 18 de outubro de 2004.(2004c)

Disponível em <www.planalto.gov.br/ccivil_03/_ato2004-2006/2004/decreto/d5245.htm>. Acesso: 17 out 2014.

Lei $\mathrm{n}^{\mathrm{o}} 11.096$, de 13 de janeiro de 2005. Institui o Programa Universidade para Todos PROUNI, regula a atuação de entidades beneficentes de assistência social no ensino superior, altera a Lei $\mathrm{n}^{\mathbf{0}}$ 10.891, de 9 de julho de 2004, e dá outras providências. Diário Oficial da União, Brasília, DF, de 29 de junho de 2005. (2005a) Disponível em <www.planalto.gov.br/ccivil_03/_ato2004-2006/2005/lei/L11096.htm> Acesso: 25 abr 2014

Lei n. 11.180, de 23 de setembro de 2005. Institui o Projeto Escola de Fábrica, autoriza a concessão de bolsas de permanência a estudantes beneficiários do Programa Universidade para Todos - PROUNI, institui o Programa de Educação Tutorial - PET, altera a Lei $\mathrm{n}^{\mathrm{o}}$ 5.537, de 21 de novembro de 1968, e a Consolidação das Leis do Trabalho - CLT, aprovada pelo Decreto-Lei $\mathrm{n}^{\mathrm{o}} 5.452$, de $1^{\circ}$ de maio de 1943 , e dá outras providências. Diário Oficial da União, Brasília, DF, de 26 de setembro de 2005.(2005b) Disponível em <www.planalto.gov.br/ccivil_03/_ato2004-2006/2005/lei/L11180.htm>. Acesso: 30 abr 2014

Decreto n. 5.773, de 09 de maio de 2006. Dispõe sobre o exercício das funções de regulação, supervisão e avaliação de instituições de educação superior e cursos superiores de graduação e seqüenciais no sistema federal de ensino. Diário Oficial da União, Brasília, DF, 10 de maio de 2006. Disponível em<http://www2.mec.gov.br/sapiens/portarias/dec5773.htm> Acesso: 11 jun 2015.

Lei n. 11.632, de 27 de dezembro de 2007. Altera o inciso I do caput do art. 44, da Lei $\overline{\mathrm{n}^{0}}$ 9394, de 20 de dezembro de 1996. Diário Oficial da União, Brasília, DF, de 28 de dezembro de 2007. (2007a) Disponível em <www.planalto.gov.br/ccivil_03/_Ato20072010/2007/Lei/L11632.htm>. Acesso: 16 dez 2015. 
Decreto n. 6.096, de 24 de abril de 2007. Institui o Programa de Apoio a Planos de Reestruturação e Expansão das Universidades Federais - REUNI. Diário Oficial da União, Brasília, DF, 25 de abril de 2007. (2007b)

Disponível em <www.planalto.gov.br/ccivil_03/_ato2007-2010/2007/decreto/d6096.htm>. Acesso: 13 jan 2016.

Ministério da Educação. Plano de Desenvolvimento da Educação: Razões, Princípios e Programas. 2007. (2007c)

Lei n. 12.202, de 14 de janeiro de 2010. Altera a Lei $\mathrm{n}^{\mathrm{o}} 10.260$, de 12 de julho de 2001, que dispõe sobre o Fundo de Financiamento ao Estudante do Ensino Superior - FIES (permite abatimento de saldo devedor do FIES aos profissionais do magistério público e médicos dos programas de saúde da família; utilização de débitos com o INSS como crédito do FIES pelas instituições de ensino; e dá outras providências). Diário Oficial da União, Brasília, DF, de 15 de janeiro de 2010.

Disponível em <www.planalto.gov.br/ccivil_03/_ato2007-2010/2010/Lei/L12202.htm. Acesso: 20 fev 2016.

Portaria Normativa n. 19, de 14 de setembro de 2011. Regulamenta o art. 11 da Lei ${ }^{\circ}$ 11.180 de 23 de setembro de 2005, alterada pela Lei $\mathrm{n}^{\circ} 12.431$ de 24 de junho de 2011;

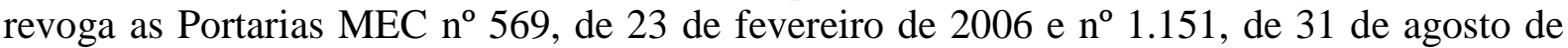
2006. Diário Oficial da União, Brasília, DF, de 15 de setembro de 2011.

Disponível em <prouniportal.mec.gov.br/legislacao/legislacao-2011/168-portaria-normativamec-n-19-de-14-de-setembro-de-2011-texto-compilado/file> Acesso: 20 jan 2016.

Lei n. 12.711, de 29 de agosto de 2012. Dispõe sobre o ingresso nas universidades federais e nas instituições federais de ensino técnico de nível médio e dá outras providências. Diário Oficial da União, Brasília, DF, de 30 de agosto de 2012. Disponível em <www.planalto.gov.br/ccivil_03/_ato2011-2014/2012/lei/112711.htm>. Acesso: 08 mar 2016.

Portaria n. 389, de 09 de maio de 2013. Cria o Programa de Bolsa Permanência e dá outras providências. Diário Oficial da União, Brasília, DF, de 13 de maio de 2013. Disponível em

<portal.mec.gov.br/component/content/article?id=18658:definidos-os-criterios-para-aconcessao-da-bolsa-permanencia> Acesso: 27 de out 2015.

Lei $n^{\circ}$ 13.005, de 25 de junho de 2014. Aprova o Plano Nacional de Educação e dá outras providências. Diário Oficial da União, Brasília, DF, 26 de junho de 2014. Disponível <www.planalto.gov.br> Acesso em: 26 de setembro de 2015

BRESSER-PEREIRA, Luiz Carlos. Da Administração Pública burocrática à gerencial. In: SEMINÁRIO SOBRE REFORMA DO ESTADO NA AMÉRICA LATINA. Brasília, maio de 1996. Revista do Serviço Público - RSP, 47 (1) janeiro-abril. 1996.

Os primeiros passos da reforma gerencial do Estado de 1995. Revista Brasileira de Direito Público - RBDP, Belo Horizonte, ano 6, n. 23, p.145-186, out/.dez. 2008. Disponível em:

<www.bresserpereira.org.br/papers/2008/08.13.Primeiros.Passos.Reforma.Gerencial.pdf>. Acesso: $1^{\circ}$ de junho de 2015 
CARVALHO, Cristina Helena Almeida de. O Prouni no governo Lula e o jogo político em torno do acesso ao ensino superior. Educação e Sociedade, Campinas, vol. 27, n. 96 Especial, p. 979-1000, out. 2006.

Disponível: <http://www.cedes.unicamp.br> Acesso: 29 agosto de 2014.

Política de expansão da educação superior nos governos democráticos brasileiros. (1995-2013). In: Sousa, J.V. (Org.) Expansão e avaliação da educação superior brasileira: formatos, desafios e novas configurações. Belo Horizonte, MG, Fino Traço, p. 119-134. Faculdade de Educação, Universidade de Brasília, UnB. Coleção Políticas Públicas de Educação, 2015.

CARVALHO, Cristina Helena Almeida de; CHAVES, Vera Lucia Jacob; VALE, Andréa Araújo do. Financeirização da educação superior no Brasil. In: Silva Jr., J.R; Sousa, J.V; Azevedo, M. L. N. de; Chaves, V.L.J.(Org). Educação Superior: Internacionalização, mercantilismo e repercussões em um campo de disputas. 1 ed. Belo Horizonte, MG: Fino Traço, 2015. Coleção Políticas Públicas de Educação. Coletânea GT - Política da Educação Superior/Anped - $9^{\text {a }}$ Edição.

CATANI, Afrânio Mendes; HEY, Ana Paula; GILIOLI, Renato de Sousa Porto. PROUNI: democratização do acesso ás Instituições de Ensino Superior? Educar, Curitiba, n. 28, p. 125140. 2006. Editora UFPR.

Disponível: <http://search.scielo.org/?q=prouni\&where=ORG>Acesso: 04 setembro de 2014

COSTA, Fabiana de Souza. O Prouni e seus egressos: uma articulação entre educação trabalho e juventude. 2012. 201 f. Tese (Doutorado em Educação) - PUC-SP, São Paulo, 2012.

CUNHA, Luiz Antonio. A universidade temporã: da Colônia à Era de Vargas, $2^{a}$ ed., Rio de Janeiro: Francisco Alves, 1986.

.O Público e o privado no ensino superior brasileiro: fronteira em movimento? Avaliação, Campinas, Sorocaba, SP, v. 2, n.4. p. 13-24. 1997

O ensino superior no octênio FHC. Educação e Sociedade., Campinas, vol. 24, n. 82, p. 37-61, abril 2003.

O desenvolvimento meandroso da educação brasileira entre o estado e o mercado. Educação e Sociedade, Campinas, vol. 28, n. 100 - Especial, p 809-829, out. 2007. Disponível em <www.cedes.unicamp.br>. Acesso: 06 novembro de 2014.

DIAS SOBRINHO, José. Educação Superior: Bem público, equidade e democratização. Avaliação, Campinas; Sorocaba, SP, v. 18, n. 1, p. 107-126, mar. 2013.

Avaliação e transformações da educação superior brasileira (1995-2009): do provão ao sinaes. Avaliação, Campinas; Sorocaba, SP, v. 15, n.1, p. 195-224, mar. 2010. (2010a)

Democratização, qualidade e crise da educação, o superior: faces da exclusão e limites da inclusão. Educação e Sociedade. Campinas, v. 31, p. 1223-1245, out.-dez.,2010. (2010b) 
DICIO. Dicionário on-line de português. Disponível em< http://www.dicio.com.br/ $>$ Acesso: 26 de abril 2016.

DUARTE, Stephanie Pellucio. Autonomia dos Multicampi das novas universidades federais: do proclamado ao real, 2015. 208p. Dissertação (Mestrado -Mestrado Profissional em Educação) - Universidade de Brasília, Programa de Pós-Graduação em Educação, Brasília, 2015.

DURHAM, Eunice. Educação superior, pública e privada.

Disponível<www.schwartzman.org.br/simon/desafios/7superior.pdf> Acesso em: 29 setembro de 2014.

FÁVERO, Maria L. de Albuquerque. A universidade no Brasil: das origens à Reforma Universitária de 1968. Educar, Curitiba, n.28, p. 17-36, 2006. Editora UFPR.

FERREIRA, Suely. Reformas na Educação Superior: de FHC a Dilma Rousseff (1995-2011). Linhas Críticas. Revista da Faculdade de Educação - UnB. Volume 18, número 36, p. 455472, maio/ago.2012.

FONSECA, Marília. Políticas públicas para a qualidade da educação brasileira: entre o utilitarismo econômico e a responsabilidade social. Caderno Cedes, Campinas, vol. 29, n. 78, p. 153-177, mai-ago. 2009.

FRANCO, Maria Laura P. B. Análise do Conteúdo. Brasília, $3^{\text {a }}$ edição: Liber Livro Editora, 2008.

GIL, Antonio Carlos. Como elaborar projetos de pesquisa. 4 ed. São Paulo: Atlas.2002.

GOMES, Alfredo Macedo e MORAES, Karine Numes de. Educação superior no Brasil contemporâneo: transição para um sistema de massa. Educação e Sociedade, vol. 33, núm. 118, Jan-março, 2012, pp. 171-190, Centro de Estudos Educação e Sociedade, Brasil.

GRIBOSKI, Claudia Maffini. Regular e/ou induzir qualidade? - os cursos de pedagogia nos ciclos avaliativos do Sinaes. 2014. 482f. Tese (Doutorado) - Universidade de Brasília, Programa de Pós-Graduação em Educação, Brasília, 2014.

GUIMARÃES, André Sathler; SILVA, Hélio Dias. A reforma universitária e os centros universitários. Revisa de Educação do Cogeime. Ano 14, n. 27. Dez. 2005.p. 97-114

INSTITUIÇÃO DE EDUCAÇÃO SUPERIOR DO DF. Missão e Visão. Disponível

< http://www.xxxxx.br/textos/2/1308/MissaoEVisao/>. Acesso: 10 de julho de 2016

INSTITUTO BRASILEIRO DE GEOGRAFIA E ESTATÍSTICA. Síntese de Indicadores Sociais: Uma análise das condições de vida da população brasileira, 2014. Estudos e Pesquisas. Informação Demográfica e Socioeconômica 34. Rio de Janeiro, 2014.

Pesquisa Nacional por Amostra de Domicílios. Síntese de Indicadores, 2014. Rio de Janeiro, 2015. 
Características Étnico-Raciais da População. Um estudo das categorias de classificação de cor ou raça, 2008. Rio de Janeiro, 2011.

INSTITUTO NACIONAL DE ESTUDOS E PESQUISAS EDUCACIONAIS. Censo da Educação Superior, 2004. Resumo Técnico, Brasília, DF, 2005.

Censo da Educação Superior, 2012. Resumo Técnico. Brasília, DF, 2014.

Censo da Educação Superior, 2013. Resumo Técnico. Brasília, DF, 2015.

Sinopse Estatística da Educação Superior - 2014. Brasília, DF, 2016.

JAMIL CURY, Carlos Roberto A desoficialização do ensino no Brasil: a Reforma Rivadávia Educação \& Sociedade, vol. 30, n. 108, outubro, 2009, p. 717-738 Centro de Estudos Educação e Sociedade Campinas, Brasil.

JESUS, W. F. Alto lá! Uma nova ordem é possível: contribuições do materialismo histórico à pesquisa e às políticas em educação. ). In: Cunha, C.; Sousa, J.V. e Silva, M. A. (Org.). O Método dialético na pesquisa em educação. Campinas, SP: Autores Associados, p. 227-238, Brasília, DF: Faculdade de Educação, Universidade de Brasília, UnB. Coleção Políticas Públicas de Educação. 2014.

KERSTENETZKY, Celia Lessa. Políticas sociais: focalização ou universalização? Revista de Economia Política, vol. 26, n.4 (104), pp.564-574, out-dez, 2006.

KOPNIN, Pavel Vassilyevitch. A dialética como lógica e teoria do conhecimento. Tradução de Paulo Bezerra. Civilização Brasileira. Rio de Janeiro, RJ, 1978. p.19-90.

KRAWCZYK, Nora Rut. O PDE: novo modo de regulação estatal? Cadernos de Pesquisa, v. 38, n. 135, p. 797-815, set./dez.2008.

KUENZER, Acácia Zencida. Desafios teórico-metodológicos da relação trabalho-educação e o papel social da escola. In: FRIGOTTO, Gaudêncio (org).Educação e crise do trabalho: perspectivas de final do século. 10 ed. Petrópolis, RJ: Vozes, Coleção Estudos culturais em Educação. 2011.

LEHER, Roberto. Projetos e modelos de autonomia e privatização das universidades públicas. Revista da ADUEL. Setembro, 2003. p.7-20.

BARRETO, Raquel Goulart e LEHER, Roberto. Do discurso e das condicionalidades do Banco Mundial, a educação superior emerge terciária. Revista Brasileira de Educação, v. 13, n.39. set./dez. 2008.

LEVIN, J.; FOX, J. A.; FORDE, D. R. Estatística para ciências humanas. 11. ed. São Paulo: Pearson Education do Brasil, 2012.

LIMA, Kátia. Contra-reforma na educação superior: de FHC a Lula. São Paulo: Xamã. 2007. 
Plano Nacional de Educação 2014-2024: nova fase do privatismo e da certificação em larga escala. Universidade e Sociedade. Andes-SN, Fev. 2015.

LÜDKE, Menga e ANDRÉ, Marli E.D.A. Pesquisa em educação: Abordagens qualitativas. São Paulo: EPU, 1986.

MANCEBO, Deise. Políticas de educação superior no Brasil. In: SILVA JR. J.R; SOUSA, J.V de; AZEVEDO, M. L. N de e CHAVES, V.L.J (Org.). Educação Superior: Internacionalização, mercantilização e repercussões em um campo de disputas. . $1^{\text {a }}$ ed. Belo Horizonte, MG: Fino Traço, 2015. Coleção Políticas Públicas de Educação. Coletânea GT -

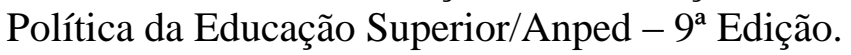

MACIEL, Lizete S.B.; NETO, Alexandre S. A educação brasileira no período pombalino: uma análise histórica das reformas pombalinas do ensino. Educação e Pesquisa. São Paulo, v. 32, n. 3, p. 465-476, set./dez. 2006.

MANZINI, Eduardo José. Entrevista semi-estruturada: análise de objetivos e de roteiros. 2003. Disponível em< www.sepq.org.br/IIsipeq/anais/pdf/gt3/04.pdf>. Acesso: 12 agosto de 2015.

MARTINS, Carlos Benedito. A Reforma Universitária de 1968 e a abertura para o ensino privado no Brasil. Educação e Sociedade, Campinas, vol. 30, n. 106, p. 15-35, jan./abr. 2009.

O ensino superior privado no Distrito Federal (1973-1993). In: 19 ENCONTRO ANUAL DA ANPOCS, Caxambu, MG, 17 a 21 out 1995. Grupo de Trabalho "Educação e Sociedade". Documento de trabalho 4/95. Disponível em:

< http://nupps.usp.br/downloads/docs/dt9504.pdf>. Acesso em: 17 março de 2016.

MARX, Karl. A questão judaica. Traduzido por: Artur Morão. Disponível em <www.lusosofia.net/textos/marx_questao_judaica.pdf>.Acesso em: 14 out. 2014.

MINISTÉRIO DA EDUCAÇÃO. Programa Universidade para Todos. Dados e Estatísticas, 2015. Disponível em< http://prouniportal.mec.gov.br/dados-e-estatisticas>. Acesso em: 13 março de 2016.

MICLIEVICH-RIBEIRO, Adélia. Reflexões sobre a utopia necessária e a universidade brasileira a partir de Darcy Ribeiro e Anísio Teixeira. In: VILLAR, José Luiz; CASTIONI, Remi (Orgs.). Diálogos entre Anísio e Darcy: o projeto da UnB e a educação brasileira. Brasília: Verbena Editora, p. 27-59. 2012.

MINTO, Lalo Watanabe. As reformas do ensino superior no Brasil: o público e o privado em questão. Campinas, SP: Autores Associados, 2006. (Coleção educação contemporânea).

NEVES, Clarissa E.B.; RAIZER, Leandro; FACHINETTO, Rochele Fellini. Acesso, expansão e equidade: novos desafios para a política educacional brasileira. Sociologias, Porto Alegre, ano 9, n.17, jan-jun. 2007, p. 124-157.

NOGUEIRA, Jaana Flávia Fernandes. Reforma da educação superior no governo Lula: debate sobre ampliação e democratização do acesso UnB. 2008. Dissertação de Mestrado. Disponível em <http://repositorio.unb.br> Acesso em 23 julho de 2014. 
OLIVEIRA, Alcivam Paulo. A relação entre o público e o privado na educação superior no Brasil e o programa universidade para todos (Prouni): ambiguidades e contradições. 2008. 304f. Tese (Doutorado). Universidade Federal de Pernambuco, CE. Educação, Recife, 2008 .

OLIVEIRA. Dalila Andrade. Das políticas de governo à política de estado: reflexões sobre a atual agenda educacional brasileira. Educação e Sociedade. Campinas, v. 32, p.323-337, abr.-jun. 2011.

OLIVEIRA. João Ferreira. Acesso à educação superior no Brasil.: entre o elitismo e as perspectivas de democratização. In: SOUSA, J. V. (Org.). Educação Superior: Cenário, impasses e propostas. Campinas, SP: Autores Associados, p.274-313, Brasília, DF: Faculdade de Educação, Universidade de Brasília, UnB. Coleção Políticas Públicas de Educação, 2014.

OTRANTO, Célia Regina. A reforma a educação superior no governo Lula: da inspiração à Implantação. GT: Política da Educação Superior no 11. UFRRJ. In SILVA Jr. João dos Reis, OLIVEIRA, João Ferreira de, MANCEBO, Deise (Orgs). Reforma Universitária: dimensões e perspectivas. Alínea Editora. Cap. 3. Anped, 2006.

PLANO DE GOVERNO DE FHC. Disponível em: <www.psdb.org.br/plano-de-governofhc-\%E2\% \%0\% 93-99-02>. Acesso em: 22 março de 2016.

PlANO DE GOVERNO 2002. Coligação Lula Presidente. Um Brasil para todos. Disponível em <http://csbh.fpabramo.org.br/uploads/programagoverno.pdf>.Acesso: 03 de março de 2016.

RICHARDSON, Roberto Jarry, José Augusto de Souza Peres...(et al).Pesquisa Social: métodos e técnicas. São Paulo: Atlas, 2014.

RISTOFF, Dilvo. O novo perfil do campus brasileiro: uma análise do perfil socioeconômico do estudante de graduação. Avaliação, Campinas, Sorocaba, SP, v. 19, n. 3, p. 723-747, nov.2014.

.Vinte e um anos de educação superior: expansão e democratização. Grupo estratégico de análise da educação superior no Brasil - GEA, n. 3, jan/jun. 2013. (2013a)

.Os desafios da educação superior na ibero-américa: e inovação, inclusão e qualidade. Avaliação, Campinas, Sorocaba, v. 18, n. 3, p. 519-545, nov. 2013 (2013b).

ROSSATO, Ricardo. O século XIX: raízes da universidade moderna. Universidade: nove séculos de história $2^{\mathrm{a}}$ ed. Passo Fundo: Unversidade de Passo Fundo, p. 82-85. 2005.

SAMPAIO, Helena. Ensino Superior no Brasil: o setor privado. São Paulo: Hucitec; FAPESP, 2000.

.O setor privado de ensino superior no Brasil: continuidades e transformações. Revista Ensino Superior Unicamp. Disponível em $<$ www.revistaensinosuperior.gr.unicamp.br/artigos/o-setor-privado-de-ensino-superior-nobrasil-continuidades-e-transformacoes>.Acesso em: 13 março de 2016. 
SANCHES GAMBOA, Silvio. Pesquisa em educação: métodos e epistemologia. 2 ed. Chapecó: Argos, 2012.

SANTANA, Gabriella Cristina da Silva. O Programa Universidade para Todos: percepções de estudantes de pedagogia do Distrito Federal. 2009. 136 f. Dissertação (Mestrado em Educação) - Faculdade de Educação, Universidade de Brasília, Brasília.

SANTOS, Catarina de A. e FERREIRA, Suely. O Plano Nacional de Educação e os Desafios da Expansão da Educação Superior. In: Sousa, J.V. (Org.) Expansão e avaliação da educação superior brasileira: formatos, desafios e novas configurações. Belo Horizonte, MG, Fino Traço, p. 119-134. Faculdade de Educação , Universidade de Brasília, UnB. Coleção Políticas Públicas de Educação, 2015.

SARAIVA, Alex Silva; NUNES, Adriana de Souza. A efetividade de programas sociais de acesso à educação superior: o caso do prouni. Revista de Administração Pública - RAP, Rio de Janeiro 45 (4): 941-64, jul./ago.2011.

Disponível: <http://search.scielo.org/?q=prouni\&where=ORG>Acesso em: 10 outubro de 2014

SAVIANI, Demerval. O plano de desenvolvimento da educação: análise do projeto do MEC. Educação e Sociedade, Campinas, vol. 28, n. 100 - Especial, p. 1231-1255, out. 2007

SEGENREICH, Stella Cecilia Duarte; CASTANHEIRA, Antonio Mauricio. Expansão, privatização e diferenciação da educação superior no Brasil pós - LDBEN/96: evidências e tendências. Aval. Pol. Públ. Educ; Rio de Janeiro, v. 17, n. 62, p. 55-86, jan./mar. 2009.

Disponível:

<search.scielo.org/?output=site \&lang=pt $\&$ from $=0 \&$ sort $=\&$ format $=$ abstract $\&$ count $=20 \& \mathrm{fb}=\&$ page $=1 \& q=$ prouni\&index $=\&$ where $=$ ORG $>$ Acesso: 15 maio de 2014 .

SEGENREICH, Stella Cecilia Duarte e NEVES, Antônio Maurício C. das. O espaço da educação à distância na expansão da educação superior brasileira pós-LDBEN/1999. In: Sousa, J.V. (Org.) Expansão e avaliação da educação superior brasileira: formatos, desafios e novas configurações. Belo Horizonte, MG, Fino Traço, p. 119-134. Faculdade de Educação, Universidade de Brasília, UnB. Coleção Políticas Públicas de Educação, 2015.

SENA, Eni de Faria. Estímulo, Acesso, Permanência e Conclusão no Ensino Superior de alunos bolsistas do Programa Universidade para Todos (ProUni): Contribuições para o enfrentamento do processo de inserção. 2011. 247 f. Tese (Doutorado em Educação) PUC/SP, São Paulo, 2011.

SGUISSARDI, Valdemar. Reforma Universitária no Brasil - 1995-2006: precária trajetória e incerto futuro. Educação e Sociedade, Campinas, vol. 27, n. 96- Especial, p. 1021-1056, out. 2006.

SILVA JÚNIOR. João dos Reis e SGUISSARD. Valdemar. A nova lei de educação superior: fortalecimento do setor público e regulação do privado/mercantil ou continuidade da privatização e mercantilização do público? Revista Brasileira de Educação. Maio/jun/Jul/Ago 2005, n²9. 
SILVA, Jane Alves da.; PUZIOL, Jeinni Kelly. A influência da teoria do capital humano e da teoria do capital social nas políticas educacionais brasileiras da atualidade. Disponível em <www.unc.br/mestrado/textos/Bibliografia-2013-Inf-teoria-cap-humano-e-teoria-docap-social-nas-pol-educ-bras\% 20.pdf $>$. Acesso: 25 junho de 2015.

SILVA, Maria Abádia. Dimensões da política do banco mundial para a educação básica. In: Educação Básica: políticas, avanços e pendências. Silva, M. A; Cunha, C. da. (Org.). Campinas, SP: Autores Associados, p. 309-343, Brasília, DF: Faculdade de Educação, Universidade de Brasília, UnB. Coleção Políticas Públicas de Educação. 2014

SILVA, Sidney Reynaldo da. Estado, Educação e Equidade no Brasil: A formação gerenciada da cidadania. Campinas, SP. Mercado de Letras, 1 ed. Outubro, 2012.

SOUSA, José Vieira. Educação superior no Distrito Federal. Consensos, conflitos e transformações na configuração de um campo. Brasília: Faculdade de Educação/Universidade de Brasília; Liber Livro. 2013.

Prospecção de tendências da recente expansão dos cursos superiores de tecnologia no Brasil. In: Sousa, J.V. (Org.) Expansão e avaliação da educação superior brasileira: formatos, desafios e novas configurações. Belo Horizonte, MG, Fino Traço, p. 119-134. Faculdade de Educação, Universidade de Brasília, UnB. Coleção Políticas Públicas de Educação, 2015.

Abordagens metodológicas no estudo de políticas educacionais. O caso do Programa de Pós-Graduação em Educação da Universidade de Brasília (2010-2012). In: Cunha, C.; Sousa, J.V. e Silva, M. A. (Org.). O Método dialético na pesquisa em educação. Campinas, SP: Autores Associados, p. 309-343, Brasília, DF: Faculdade de Educação, Universidade de Brasília, UnB. Coleção Políticas Públicas de Educação. 2014.

Aumento de vagas ociosas na educação superior brasileira (2003 - 2008): Redução do poder indutor da expansão via setor privado? Anped, Rio de Janeiro, 2010. Disponível em: < www.anped11.uerj.br/AUMENTODEVAGAS.pdf>. Acesso: 25 outubro de 2015.

A recente expansão do ensino superior privado no Distrito Federal: uma análise de suas principais motivações no período 1995-2001. Gest. Ação. Salvador, v.7, n.1, p.65-85. Jan./abr. 2004.

TRIVIÑOS, Augusto N.S. Introdução à pesquisa em ciências sociais. A pesquisa qualitativa em educação: O positivismo; A fenomenologia; O marxismo. São Paulo, SP. Atlas, 1987. p. 137-145.

VIEIRA, Sofia Lerche. Reforma Universitária de 1968 (40 anos)/Córdoba (90 anos). Reforma Universitária - Ecos de 1968. Disponível em <http://31reuniao.anped.org.br> Acesso em: 13 nov 2015

WEBER, Silke. Avaliação e regulação da educação superior: conquistas e impasses. Educação e Sociedade, Campinas, v. 31, n. 113, p. 1247-1269, out-dez. 2010. 
APÊNDICES 
UNIVERSIDADE DE BRASÍLIA - UnB

FACULDADE DE EDUCAÇÃO - FE

PROGRAMA DE PÓS-GRADUAÇÃO EM EDUCAÇÃO - MESTRADO PROFISSIONAL - PPGE/MP

GESTÃO DE POLÍTICAS E SISTEMAS EDUCACIONAIS - GPSE

APÊNDICE I

ROTEIRO DE ENTREVISTA ABMES

I - IDENTIFICAÇÃO DO(A) INTERLOCUTOR(A)

ATUAÇÃO NA ASSOCIAÇÃO BRASILEIRA DE MANTENEDORES DE ENSINO SUPERIOR (ABMES)

1.1. Função:

1.2. Tempo na função:

FORMAÇÃO

1.3. Curso(s) de Graduação:

1.4. Pós-Graduação Lato

Sensu:

1.5. Pós-Graduação Stricto Sensu:

1.6. Trajetória acadêmica e profissional: 


\section{II - PERGUNTAS}

\section{BLOCO 1 - A expansão da educação superior no Brasil a partir da década de 1990}

1. Qual a sua avaliação em relação à expansão da educação superior no Brasil, a partir do governo de Fernando Henrique Cardoso, aos dias de hoje? Como o senhor avalia o financiamento dessa expansão nos governos FHC e Lula?

2. Como o senhor analisa a expansão da educação superior brasileira e a democratização do acesso a esse nível educacional, a partir da década de 1990 ?

3. De que maneira o senhor analisa a expansão da educação superior no Brasil, sob a perspectiva dos setores público e privado, fazendo uma comparação entre os governos FHC e Lula?

4. Em que medida você considera que a expansão da educação superior brasileira alcançou os segmentos mais desprovidos economicamente da população?

\section{BLOCO 2 - A democratização do acesso à educação superior no Brasil e o setor privado}

1. Qual sua percepção sobre o acesso à educação superior, a partir do governo Lula, considerando o protagonismo do setor privado?

2. Considerando a eqüidade, como você vê a questão da democratização do acesso à educação superior, numa análise comparativa entre os governos FHC e Lula?

3. Em que medida você considera que a Constituição de 1988 e a LDB, Lei 9.394/96 contribuiram para estimular a privatização do acesso à educação superior?

4. Em sua avaliação, qual a importância do setor privado para ampliar e democratizar o acesso à educação superior no Brasil?

\section{BLOCO 3 - O ProUni e a democratização do acesso à educação superior}

1. A partir do PNE 2001/2010, de que maneira o senhor considera que o ProUni contribuiu para a ampliação e democratização do acesso à educação superior?

2. Qual a sua análise em relação à democratização do acesso e o ProUni, considerando a renda e as cotas para negros, indígenas e pessoas com deficiência?

3. Em que medida você acredita que o ProUni contribuiu para que jovens de baixa renda pudessem frequentar cursos de alta concorrência, como medicina e engenharia? 
4. A partir das dimensões qualidade e permanência, de que maneira você acredita que o ProUni pode contribuir com as metas estabelecidas pelo PNE de 2014?

5. Qual a sua análise acerca da avaliação dos efeitos do Programa Universidade para Todos? O senhor acha que deveria ter avaliações mais sistemáticas desta Política?

6. Como o senhor vê a diferença entre as Universidades que aderiram ao ProUni, daquelas que optaram por não participar do Programa?

7. Qual a sua percepção sobre o acesso e permanência de alunos cotistas do ProUni, em cursos de alta concorrência, como medicina e engenharia, em relação aos cursos menos concorridos, como letras e administração 
UNIVERSIDADE DE BRASÍLIA - UnB

FACULDADE DE EDUCAÇÃO - FE

PROGRAMA DE PÓS-GRADUAÇÃO EM EDUCAÇÃO - MESTRADO PROFISSIONAL - PPGE/MP

GESTÃO DE POLÍTICAS E SISTEMAS EDUCACIONAIS - GPSE

APÊNDICE II

ROTEIRO DE ENTREVISTA IES

I - IDENTIFICAÇÃO DO(A) INTERLOCUTOR(A)

ATUAÇÃO NA INSTITUIÇÃO PRIVADA DE EDUCAÇÃO SUPERIOR

Função:

Tempo na Função:

FORMAÇÃO

Curso(s) de Graduação:

Pós-Graduação Lato Sensu:

Pós-Graduação Stricto Sensu:

Trajetória acadêmica e profissional: 


\section{II - PERGUNTAS}

\section{BLOCO 1 - A expansão da educação superior no Brasil a partir da década de 1990}

1. Qual a sua avaliação em relação à expansão da educação superior no Brasil, a partir do governo de Fernando Henrique Cardoso, aos dias de hoje? Como o senhor avalia o financiamento dessa expansão nos governos?

2. Como o senhor analisa a expansão da educação superior brasileira e a democratização do acesso a esse nível educacional, a partir da década de 1990?

3. De que maneira o senhor analisa a expansão da educação superior no Brasil, sob a perspectiva dos setores público e privado, fazendo uma comparação entre os governos FHC e Lula?

4. Em que medida você considera que a expansão da educação superior brasileira alcançou os segmentos mais desprovidos economicamente da população?

\section{BLOCO 2 - O ProUni e a democratização do acesso à educação superior}

1. Considerando a eqüidade, como você vê a questão da democratização do acesso à educação superior, numa análise comparativa entre os governos FHC, Lula e Dilma?

2. Em sua avaliação, qual a importância do setor privado para ampliar e democratizar o acesso à educação superior no Brasil?

3. Qual a sua análise em relação ao ProUni e a democratização do acesso à educação superior?

4. Em que medida você acredita que o ProUni contribuiu para que jovens de baixa renda pudessem frequentar cursos de alta concorrência, como medicina e engenharia?

\section{BLOCO 3 - O ProUni, a democratização do acesso e a Insituição de educação superior}

1. Em que medida você considera que o ProUni contribuiu para que esta Instituição ampliasse o acesso à educação superior com mais eqüidade?

2. Na sua visão, qual a contribuição do ProUni para o ingresso e permanência do aluno nesta IES?

3. Que relação você faz entre o Programa Universidade para Todos e a qualidade na formação dos bolsistas desta instituição?

4. Em geral, qual o perfil sócio-econômico dos bolsistas do ProUni, no curso.....? 
5. Você considera que haja diferença no desenvolvimento acadêmico de um aluno bolsista em comparação com um não bolsista?

6. Qual a sua análise em relação aos alunos bolsistas do ProUni, no que diz respeito à interação com os demais alunos não bolsistas? 
UNIVERSIDADE DE BRASÍLIA - UnB

FACULDADE DE EDUCAÇÃO - FE

PROGRAMA DE PÓS-GRADUAÇÃO EM EDUCAÇÃO - MESTRADO PROFISSIONAL - PPGE/MP

GESTÃO DE POLÍTICAS E SISTEMAS EDUCACIONAIS - GPSE

\section{APÊNDICE III}

ROTEIRO DE ENTREVISTA MEC

\section{I - IDENTIFICAÇÃO DO(A) INTERLOCUTOR(A)}

ATUAÇÃO NO MINISTÉRIO DA EDUCAÇÃO - MEC

Função:

tempo na função:

FORMAÇÃO

Curso(s) de Graduação:

Pós-Graduação Lato Sensu:

Pós-Graduação Stricto Sensu:

Trajetória acadêmica e profissional: 


\section{II - PERGUNTAS}

\section{BLOCO 1 - A expansão da educação superior no Brasil a partir da década de 1990}

1. Qual a sua avaliação em relação à expansão da educação superior no Brasil, a partir do governo de Fernando Henrique Cardoso, aos dias de hoje? Como o senhor avalia o financiamento dessa expansão nos governos?

2. Como o senhor analisa a expansão da educação superior brasileira e a democratização do acesso a esse nível educacional, a partir da década de 1990 ?

3. De que maneira o senhor analisa a expansão da educação superior no Brasil, sob a perspectiva dos setores público e privado, fazendo uma comparação entre os governos FHC e Lula?

4. Em que medida você considera que a expansão da educação superior brasileira alcançou os segmentos mais desprovidos economicamente da população?

\section{BLOCO 2 - A democratização do acesso à educação superior no Brasil e o setor privado}

1. Qual sua percepção sobre o acesso à educação superior, a partir do governo Lula, considerando o protagonismo do setor privado?

2. Considerando a eqüidade, como você vê a questão da democratização do acesso à educação superior, numa análise comparativa entre os governos FHC e Lula?

3. Em que medida você considera que a Constituição de 1988 e a LDB, Lei 9.394/96 contribuiram para estimular a privatização do acesso à educação superior?

4. Em sua avaliação, qual a importância do setor privado para ampliar e democratizar o acesso à educação superior no Brasil?

\section{BLOCO 3 - O ProUni e a democratização do acesso à educação superior}

1. A partir do PNE 2001/2010, de que maneira o senhor considera que o ProUni contribuiu para a ampliação e democratização do acesso à educação superior?

2. Qual a sua análise em relação à democratização do acesso e o ProUni, considerando a renda e as cotas para negros, indígenas e pessoas com deficiência?

3. Em que medida você acredita que o ProUni contribuiu para que jovens de baixa renda pudessem frequentar cursos de alta concorrência, como medicina e engenharia? 
4. A partir das dimensões qualidade e permanência, de que maneira você acredita que o ProUni pode contribuir com as metas estabelecidas pelo PNE de 2014?

5. Qual a sua análise acerca da avaliação dos efeitos do Programa Universidade para Todos? O senhor acha que deveria ter avaliações mais sistemáticas desta Política?

6. Como o senhor vê a diferença entre as Universidades que aderiram ao ProUni, daquelas que optaram por não participar do Programa?

7. Qual a sua percepção sobre o acesso e permanência de alunos cotistas do ProUni, em cursos de alta concorrência, como medicina e engenharia, em relação aos cursos menos concorridos, como letras e administração 


\section{APÊNDICE IV}

\section{Questionário de Pesquisa Acadêmica}

Prezado (a) estudante,

Meu nome é Luciana da Silva Castro, sou servidora do Ministério da Educação (MEC) e aluna do Mestrado Profissional do Programa de PósGraduação

da Faculdade de Educação

da Universidade de Brasília (FE/UnB). Este questionário é parte de pesquisa sobre o

Programa Universidade para Todos (ProUni), sob a orientação do Prof. Dr. José Vieira de Sousa.

O estudo tem como objetivo analisar em que medida essa política promove a democratização do acesso à educação superior. Para isso, serão coletadas informações, via este questionário online, de bolsistas ingressantes na, no período entre 1/2010 a 2/2015, nos cursos de Administração, Engenharia Civil, Letras e Medicina. Ressalto que a participação é voluntária e será preservada a identidade dos respondentes. A pesquisa foi aprovada pelo Comitê de Ética em Pesquisa (CEP), da IES, conforme o protocolo n ${ }^{\circ} 48869815.9 .0000 .0029$.

O questionário não levará mais que 10 minutos do seu tempo. As respostas serão migradas automaticamente para uma planilha em Excel e, posteriormente, analisadas com o suporte do software SPSS (Statistical Package for the Social Sciences).

Para quaisquer dúvidas entrar em contato comigo, pelo email lucianacastro.silva04@gmail.com ou pelos telefones (61) 92351212/20227504

Agradeço a sua participação, sem a qual esta pesquisa não será possível

1. Ciente do objetivo deste questionário, assinale que você concorda em participar, de forma voluntária e anônima.

Marque todas que se aplicam.

Sim

2. Em qual curso você está matriculado?

Marque todas que se aplicam.

Administração

Engenharia Civil

Letras

Medicina

3. Qual a modalidade do seu curso?

Marque todas que se aplicam.

Presencial

EAD

4. Caso seu curso seja em EAD, indique seu pólo, para as aulas presenciais

Marque todas que se aplicam.

Brasília

Belo Horizonte

Coronel Fabriciano

Manaus 
Porto Alegre

Rio de Janeiro

São José dos Campos

TV Católica Virtual 3

Anápolis

Belém

Fortaleza

Salvador

São Paulo

Vitória

TV Católica Vitual

Campos dos Goytacazes

Palmas

Recife

Santo André

Uberlândia

Tokyo (Japão)

Boston (EUA)

Luanda (Angola)

5. Em qual período você ingressou?

Marque todas que se aplicam.

$1^{\circ}$ semestre de 2010

$2^{\circ}$ semestre de 2010

$1^{\circ}$ Semestre de 2011

$2^{\circ}$ Semestre de 2011

$1^{\circ}$ Semestre de 2012

$2^{\circ}$ Semestre de 2012

$1^{\circ}$ Semestre de 2013

$2^{\circ}$ Semestre de 2013

$1^{\circ}$ Semestre de 2014

$2^{\circ}$ Semestre de 2014

$1^{\circ}$ Semestre de 2015

$2^{\circ}$ Semestre de 2015

6. Qual a pontuação que você teve no Enem e utilizada para a seleção no ProUni?

Marque todas que se aplicam.

De 450 a 550 pontos

De 551 a 650 pontos

De 651 a 750 pontos

De 751 a 850 pontos

Acima de 851 pontos

7. Você utilizou critério de política afirmativa/cota para ingressar no ProUni? Marque todas que se aplicam.

Sim

Não 
8. Se utilizou critério de política afirmativa, especifique qual.

Marque todas que se aplicam.

Étnicoracial

(pretos, pardos ou indígenas)

Portador de deficiência

9. Qual a sua idade no momento de seleção do ProUni?

Marque todas que se aplicam.

Menos de 18 anos

18 anos

19 anos

20 anos

21 anos

22 anos

23 anos

24 anos

De 25 a 30 anos

De 31 a 35 anos

De 36 a 40 anos

De 41 a 45 anos

Acima de 46 anos

10. Qual o seu gênero

Marque todas que se aplicam.

Masculino

Feminino

11. Como você se considera?

Marque todas que se aplicam.

Branco(a)

Preto(a)

Pardo(a)

Indígena

Amarelo(a)

12. Estado civil no momento de ingresso no ProUni

Marque todas que se aplicam.

Solteiro(a)

Casado(a)

Separado(a) judicialmente/divorciado(a)

Viúvo(a)

Outro

13. Onde você concluiu o ensino médio?

Marque todas que se aplicam.

Integralmente em escola pública

Integralmente em escola privada, com bolsa integral

Parcialmente em escola pública e privada, com bolsa integral 
14. Qual o nível de escolaridade do seu pai?

Marque todas que se aplicam.

Nenhuma escolaridade

Ensino Fundamental (anos iniciais) do

$1^{\circ}$ ao $5^{\circ}$ ano (antiga $1^{\mathrm{a}}$ a $4^{\mathrm{a}}$ série)

Ensino Fundamental (anos finais) do

$6^{\circ}$ ao $9^{\circ}$ ano (antiga $5^{\text {a }}$ a $8^{\mathrm{a}}$ série)

Ensino Médio incompleto

Ensino Médio completo

Educação Superior incompleta

Educação Superior completa

Especialização

Mestrado

Doutorado

15. Qual o nível de escolaridade de sua mãe?

Marque todas que se aplicam.

Nenhuma escolaridade

Ensino Fundamental (anos iniciais) do

$1^{\mathrm{o}}$ ao $5^{\mathrm{o}}$ ano (antiga $1^{\mathrm{a}}$ a $4^{\mathrm{a}}$ série)

Ensino Fundamental (anos finais) do

$6^{\circ}$ ao $9^{\circ}$ ano (antiga $5^{a}$ a $8^{a}$ série)

Ensino Médio incompleto

Ensino Médio completo

Educação Superior incompleta

Educação Superior completa

Especialização

Mestrado

Doutorado

16. Você tem renda própria?

Marque todas que se aplicam.

Sim

Não

17. Qual o valor de sua renda mensal? Valor de referência: salário mínimo disposto no Decreto no 8.618 de 29/12/2015

Marque todas que se aplicam.

Menos de R \$ 880,00

De $\mathrm{R} \$ 881,00$ a $\mathrm{R} \$ 1.320,00$

De $\mathrm{R} \$ 1.321,00$ a $\mathrm{R} \$ 1.760,00$

De $\mathrm{R} \$ 1.761,00$ a $\mathrm{R} \$ 2.200,00$

De R $\$ 2.201,00$ a $\mathrm{R} \$ 2.640,00$

De R \$ 2.641,00 a R \$3.080,00

De $R \$ 3.081$ a $\mathrm{R} \$ 3.520,00$

De R\$3.521,00 a R\$3.960,00

De R \$ 3.961,00 a R \$ 4.400,00

Acima de R \$ 4.401,00 
18. Quantas pessoas têm renda em sua casa?

Marque todas que se aplicam.

1

2

3

4

5

6

De 7 a 9

Acima de 9

19. Somando a sua renda (se tiver), com a das demais pessoas que moram com você, quanto é, aproximadamente, a renda familiar? (Considere a renda de todos os integrantes que moram com você).

Marque todas que se aplicam.

Menos de R \$ 880,00

De $\mathrm{R} \$ 881,00$ a $\mathrm{R} \$ 1.320,00$

De R $\$ 1.321,00$ a $\mathrm{R} \$ 1.760,00$

De R\$1.761,00 a R\$2.200,00

De R \$ 2.201,00 a R \$ 2.640,00

De R \$ 2.641,00 a R\$3.080,00

De R \$3.081 a R \$3.520,00

De R $\$ 3.521,00$ a R $\$ 3.960,00$

De R $\$ 3.961,00$ a R $\$ 4.400,00$

Acima de $\mathrm{R} \$ 4.401,00$

20. Você recebe ou recebeu alguma bolsa ou auxílio para ajudar em sua permanência na universidade?

Marque todas que se aplicam.

Não recebo/não recebi

Sim, bolsa permanência do ProUni

Sim, bolsa da própria instituição

Sim, outro tipo de bolsa oferecida por órgão governamental

Sim, outro tipo de bolsa oferecida por órgão nãogovernamental

21. Como professor da rede pública de ensino, você utilizou essa situação para ser selecionado pelo ProUni?

Marque todas que se aplicam.

Sim

Não

22. Abaixo estão algumas alternativas relativas ao ProUni. Indique se você concorda ou discorda, seguindo a escala proposta. O ProUni contribui para a expansão do acesso à educação superior.

Marcar apenas uma oval.

12345 
23. O ProUni contribui para que a expansão do acesso à educação superior alcance os segmentos da sociedade, mais desprovidos economicamente.

Marcar apenas uma oval.

12345

24. O ProUni contribui para que alunos de baixa renda possam frequentar cursos de alto custo, como medicina e engenharia civil.

Marcar apenas uma oval.

12345

25. O ProUni contribui para o acesso e permanência de alunos cotistas (pretos, pardos, indígenas e portares de deficiência) tanto em cursos de alta concorrência, como medicina e engenharia civil, quanto em cursos menos concorridos, como administração e letras.

Marcar apenas uma oval.

12345

26. A expansão e democratização do acesso à educação superior não seria possível sem o setor privado e políticas públicas com a do ProUni.

Marcar apenas uma oval.

12345

27. O ProUni é uma política pública que mais beneficia as instituições de educação superior privadas, do que o estudante de baixa renda.

Marcar apenas uma oval.

12345

28. O ProUni auxilia os estudantes a ter uma profissão.

Marcar apenas uma oval.

12345

29. O governo deveria ter avaliações mais sistemáticas do Programa Universidade para Todos.

Marcar apenas uma oval.

12345

30. A bolsa permanência do ProUni atende às necessidades financeiras dos estudantes.

Marcar apenas uma oval.

12345

31. O Programa Universidade para Todos melhorou minha vida, ao criar condições para o ingresso em uma instituição de educação superior.

Marcar apenas uma oval.

12345

32. Sem o ProUni, dificilmente, eu teria condições de ingressar em um curso de nível superior.

Marcar apenas uma oval. 
12345

33. Qual a sua principal crítica ou sugestão ao Programa Universidade para Todos (ProUni)? 


\section{APÊNDICE V}

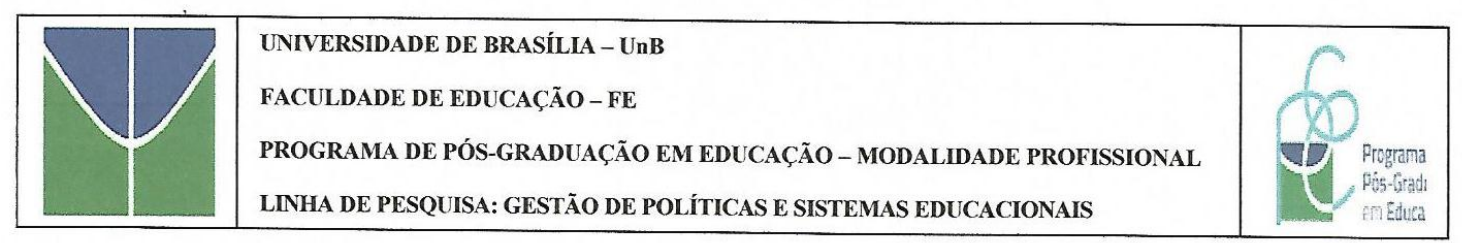

\section{CARTA DE APRESENTAÇÃO}

Brasília, 24 de junho de 2015.

Ilmo(a). Senhor(a),

Apresento a V. Sa. a Senhora Luciana da Silva Castro, estudante regularmente matriculada no Curso de Pós-Graduação em Educação - Modalidade Presencial em Educação do Programa de Pós-Graduação em Educação da Universidade de Brasília, matrícula 13/0178284. Essa estudante está desenvolvendo uma pesquisa que tem o objetivo de analisar em que medida o Programa Universidade para Todos (ProUni), como política pública de educação, vem contribuindo para a democratização do acesso à educação superior brasileira no período do $1^{\circ}$ semestre de 2013 ao $1^{\circ}$ semestre de 2015.

Em função do objetivo da pesquisa, é necessário que a referida mestranda realize entrevista individual com V. Sa. Desta forma, solicito vossa colaboração no sentido de conceder, aproximadamente, 40 (quarenta) minutos de sua agenda de trabalho para a realização da entrevista. Caso permita, a entrevista será gravada, sendo posteriormente degravada, com o objetivo de formar uma base de dados para a pesquisa e posterior análise.

Por oportuno, informo que todo material coletado será utilizado somente na pesquisa e sua participação não será relacionada com trechos do depoimento, que possam implicar sua identifícação. Colocamo-nos à disposição para, ao final do trabalho e dependendo do seu interesse, realizar um encontro para a exposição dos resultados da pesquisa. A participação nessa pesquisa é voluntária e poderá haver a desistência a qualquer momento, não havendo previsão de gastos ou remuneração.

Ressaltando a importância de sua valiosa colaboração para o estudo, agradeço antecipadamente, e me coloco à disposição para quaisquer esclarecimentos.

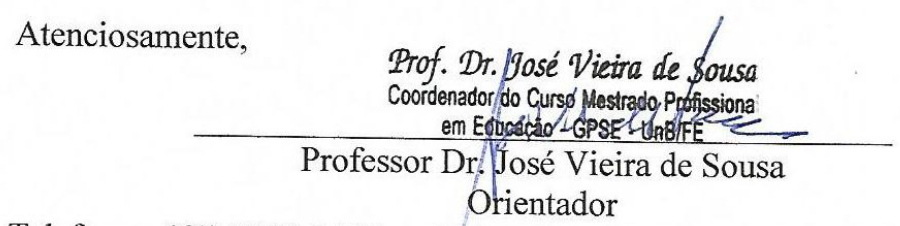

Telefones: (61) 9968-3447 ou 3307-6241 (UnB) e-mail: sovieira@,fe.unb.br

Ilmo(a). Sr(a):

Função:

Nest a 


\section{APÊNDICE VI}

\begin{tabular}{|l|l|l|}
\hline & $\begin{array}{l}\text { UNIVERSIDADE DE BRASILIA - UnB } \\
\text { FACULDADE DE EDUCAÇÃO - FE } \\
\text { PROGRAMA DE PÓS-GRADUAÇÃO EM EDUCAÇÃO-MODALIDADE PROFISSIONAL } \\
\text { LINHA DE PESQUISA: GESTÃO DE POLÍTICAS E SISTEMAS EDUCACIONAIS }\end{array}$ \\
\hline
\end{tabular}

TERMO DE CONSENTIMENTO LIVRE E ESCLARECIDO

Responsável pelo projeto: Luciana da Silva Castro - Matrícula: 13/0178284

Mestranda do Programa de Pós-Graduação em Educação/PPGE da UnB (Modalidade Profissional)

$\mathrm{Eu}$, abaixo assinado, declaro que fui informado(a), de forma clara e objetiva, acerca da pesquisa de mestrado que tem por objetivo analisar em que medida o Programa Universidade para Todos (ProUni), como política pública de educação, vem contribuindo para a democratização do acesso à educação superior brasileira no período do $1^{\circ}$ semestre de 2013 ao $1^{\circ}$ semestre de 2015.

Afirmo que tenho pleno conhecimento de que, nessa pesquisa, serão realizados os seguintes procedimentos: entrevista semiestruturada e análise de documentos diversos. Estou ciente de que não é obrigatória a minha participação nesse estudo, caso me sinta constrangido(a), antes ou durante a realização do trabalho, e de que os materiais utilizados para a coleta das informações serão destruídos após o registro dos dados. Declaro que tenho ciência de que a pesquisadora manterá em caráter confidencial todas as respostas que comprometam a minha privacidade e que tenho conhecimento de que, caso solicite, receberei informações atualizadas durante o estudo, ainda que isto possa afetar a minha vontade de continuar dele participando.

Declaro, ainda, que me foi esclarecido que essas informações poderão ser obtidas por intermédio de Luciana da Silva Castro (9235-1212) ou e-mail lucianacastro.silva04@gmail.com e que o resultado da pesquisa somente será divulgado com objetivo científico-acadêmico, mantendo-se em sigilo a minha identidade e, se for o caso, meu vínculo institucional. Por fim, afirmo estar ciente de que a minha participação nesse estudo é voluntária e poderei desistir a qualquer momento, não havendo previsão de gastos ou remuneração. E por estar de pleno acordo com os termos ajustados e mencionados neste documento, assinamos o presente instrumento em duas (duas) vias de igual teor e forma, para um só efeito.

Brasília-DF, 24 de junho de 2015.

Interlocutör(a) da pesquisa

Luciana da Silva Castro

Responsável pela pesquisa 


\section{APÊNDICE VII}

\begin{tabular}{|l|l|l|}
\hline & $\begin{array}{l}\text { UNIVERSIDADE DE BRAŚLIA - UnB } \\
\text { FACULDADE DE EDUCAÇÃO - FE } \\
\text { PROGRAMA DE PÓS-GRADUAÇÃO EM EDUCAÇÃO - MODALIDADE PROFISSIONAL } \\
\text { LINHA DE PESQUISA: GESTÃO DE POLÍTICAS E SISTEMAS EDUCACIONAIS }\end{array}$ \\
\hline
\end{tabular}

\section{TERMO DE CONSENTIMENTO LIVRE E ESCLARECIDO PARA GRAVAÇÃO DE ENTREVISTA}

$\mathrm{Eu}$, declaro, para os devidos fins, que aceitei participar da pesquisa de mestrado que tem por objetivo "analisar em que medida o Programa Universidade para Todos (ProUni), como política pública de educação, vem contribuindo para a democratização do acesso à educação superior brasileira no período do $1^{\circ}$ semestre de 2013 ao $1^{\circ}$ semestre de 2015.

Também declaro que autorizo a gravação da entrevista e sua utilização para a pesquisa, desde que minha identidade permaneça resguardada e não seja utilizada em prejuízo da(s) pessoa(s) envolvida(s) e/ou da instituição. Por fim, informo que estou ciente de que a minha participação neste estudo é voluntária e poderei desistir a qualquer momento, não havendo previsão de gastos ou remuneração. Por ser verdade, firmo a presente, assinando o presente instrumento em duas (duas) vias de igual teor e forma, para um só efeito.

Brasília-DF, 24 de junho de 2015.

Interlocutor(a) da pesquisa

\section{Luciana da Silva Castro}

Responsável pela pesquisa 


\section{APÊNDICE VIII O TERMO DE CONSENTIMENTO LIVRE E ESCLARECIDO}

O (a) Senhor(a) está sendo convidado(a) a participar do projeto: Democratização do acesso à educação superior - O ProUni e uma instituição privada do Distrito Federal, um estudo de caso sob responsabilidade do Prof. Doutor José Vieira de Sousa e da aluna Luciana da Silva Castro.

O objetivo desta pesquisa é: Analisar em que medida o Programa Universidade para Todos (ProUni) está sendo uma política pública que democratiza o acesso à educação superior, a partir de uma universidade privada do Distrito Federal, esta pesquisa justifica-se, pois avaliar uma política pública da importância do Programa Universidade para Todos contribui para o aprimoramento das ações governamentais relacionadas à democratização do acesso à educação superior no Brasil.

$\mathrm{O}$ (a) senhor(a) receberá todos os esclarecimentos necessários antes e no decorrer da pesquisa e the asseguramos que seu nome não aparecerá sendo mantido o mais rigoroso sigilo através da omissão total de quaisquer informações que permitam identificá-lo(a). Senhor(a) pode se recusar a responder qualquer questão (no caso da aplicação de um questionário) que the traga constrangimento, podendo desistir de participar da pesquisa em qualquer momento sem nenhum prejuízo para o(a) senhor(a).

A sua participação será da seguinte forma: serão realizadas entrevistas semiestruturada, com alguns gestores da instituição privada do Distrito Federal, incluindo os coordenadores dos cursos pesquisados, com duração aproximada de 40 (quarenta minutos) e será realizado um grupo focal com os alunos, bolsistas do ProUni, ingressantes nos cursos de medicina, engenharia civil, letras e administração, nos anos de 2013 a 2015, para aplicação de questionário, com duração prevista de 1 (uma) hora.

Os resultados da pesquisa serão divulgados na Universidade de Brasília e na instituição que serviu como lócus da pesquisa, podendo ser publicados posteriormente. Os dados e materiais utilizados na pesquisa ficarão sobre a guarda do pesquisador.

Este projeto possui os seguintes benefícios contribuir para o incremento do Programa Universidade para Todos - ProUni e apresenta os seguintes riscos: possibilidade de causar constrangimento com determinadas perguntas que serão minimizados da seguinte forma: optar por não responder à pergunta.

Se o(a) Senhor(a) tiver qualquer dúvida em relação à pesquisa, por favor telefone para: Luciana da Silva Castro do Programa do Programa de Pós Graduação em Educação da Faculdade de Educação da Universidade de Brasília, telefone: (61) 9235 1212, no horário das 9h às 18h.

Este projeto foi Aprovado pelo Comitê de Ética em Pesquisa da xxx, número do protocolo 48869815.9.0000.0029. As dúvidas com relação à assinatura do TCLE ou os direitos do sujeito da pesquisa podem ser obtidos também pelo telefone: (61) xxxx-xxxx.

Este documento foi elaborado em duas vias, uma ficará com o pesquisador responsável e a outra com o voluntário da pesquisa.

Nome / assinatura

Pesquisador Responsável

Nome e assinatura

Brasília, de de 